\author{
UNIVERSIDADE DE SÃO PAULO \\ INSTITUTO DE FÍSICA DE SÃO CARLOS
}

JULIO CESAR QUEIROZ DE CARVALHO

Avaliação do impacto do jogo "Sintetizando Proteínas" no processo de ensino-aprendizagem de alunos do Ensino Médio 



\title{
Avaliação do impacto do jogo "Sintetizando Proteínas" no processo de ensino-aprendizagem de alunos do Ensino Médio
}

\begin{abstract}
Dissertação apresentada ao Programa de Pós-graduação do Instituto de Física de São Carlos, da Universidade de São Paulo para obtenção do título de Mestre em Ciências.
\end{abstract}

Área de concentração: Física Aplicada. Opção: Biomolecular.

Orientadora: Profa. Dra. Nelma Regina Segnini Bossolan 
AUTORIZO A REPRODUÇÃO E DIVULGAÇÃO TOTAL OU PARCIAL DESTE TRABALHO, POR QUALQUEER MEIO CONVENCIONAL OU ELETRÔNICO, PARA FINS DE ESTUDO E PESQUISA, DESDE QUE CITADA A FONTE.

Ficha catalográfica elaborada pelo Serviço de Biblioteca e Informação IFSC/USP

Carvalho, Julio Cesar Queiroz de

Avaliação do impacto do jogo "Sintetizando Proteínas" no processo de ensino-aprendizagem de alunos do Ensino Médio./Julio Cesar Queiroz de Carvalho; orientadora Nelma Regina Segnini Bossolan-- São Carlos, 2009.

$234 \mathrm{p}$.

Dissertação (Mestrado - Programa de Pós-Graduação em Física - Área de concentração: Física Aplicada - opção: Biomolecular ) Instituto de Física de São Carlos da Universidade de São Paulo.

1. Proteínas. 2. Síntese protéica. 3. Jogo de regras. .4. Concepções no ensino de biologia. 5. Vygotsky I. Título. 

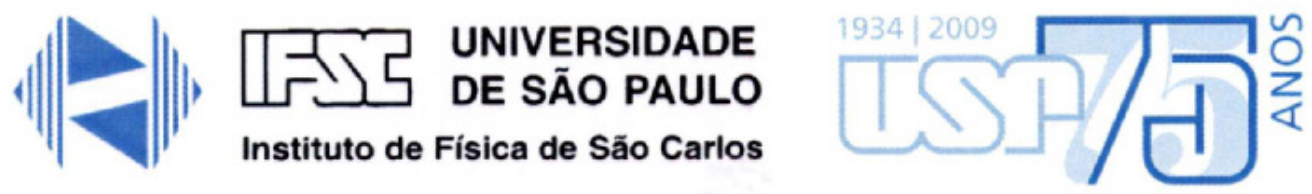

Caixa Postal 369 13560-970 São Carlos, SP Av. Trabalhador São-carlense, 400 13566-590 - São Carlos, SP

\section{FOLHA DE APROVAÇÃO}

Julio Cesar Queiroz de Carvalho

Dissertação apresentada ao Instituto de Fisica de São Carlos da Universidade de São Paulo para obtenção do titulo de Mestre em Ciências. Área de Concentração: Física Aplicada - Opção:

Fisica Biomolecular.

Aprovado em: 11/02/2009

Comissão Julgadora

Profa. Dra. Nelma Regina Segnini Bossolan

Instituição: IFSC/USP

Assinatura

Prof. Dr. Dietrich Schiel

Instituição: IFSC/USP

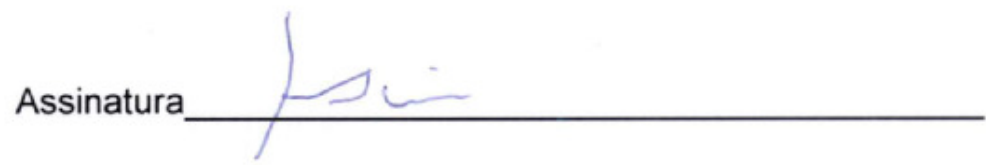

Prof. Dr. Eduardo Galembeck Instituição: UNICAMP

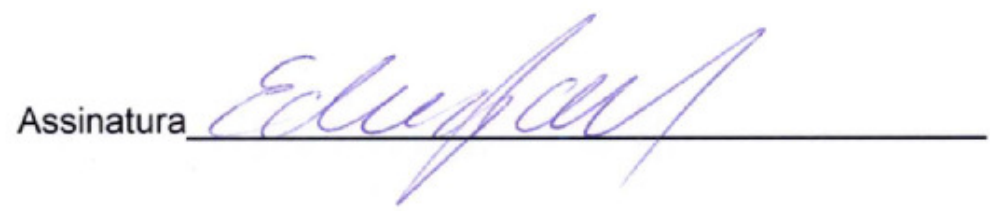



A Sheila, minha amada espasa. que tanta me inspira pela sua garra e determinaçãa em busca de seus sanhos quanto me encauta pela forma delicada e carinhosa cam a qual me trata $e$ cuida de mim, pela apaia e compreensãa. imprescindiveis à canclusãa desse trabalha

Aos meus pais José c Sânia que cam amor e dedicaçäa incondicionais me ensinaram principios e valores essenciais que carrega camiga e pela exempla de vida conjugal, regada com muita amor e dedicaçãa, da qual me argulha e me espelha. 


\section{AGRADECIMENTOS}

Agradeço,

Primeiramente a Deus por sua infinita bondade e misericórdia, por iluminar sempre o meu caminho, enriquecer-me com suas bênçãos e por me dar sabedoria e discernimento para conduzir minha vida;

À profa. Dra. Nelma Regina Segnini Bossolan, por sua competência, paciência e dedicação ao orientar-me, pelo aprendizado que obtive ao seu lado, e por ter depositado sua confiança em meu trabalho e potencial;

Aos meus pais Sônia e José, pelo acompanhamento, preocupação, incentivo, amor incondicional e pela educação, que me acompanhará ao longo de toda a minha jornada;

À minha amada esposa Sheila, que esteve ao meu lado em todos os momentos, me incentivando, me dando forças, me compreendendo e acalmando-me no afago de seus braços nos momentos de tensão;

À minhas irmãs Juciney, Jucilene, Jucimara e Jussara e respectivos maridos Antonio, Leandro, Hudson e Maximilian, meus sogros Maria Cândida e José Orlando, minhas cunhadas Kátia e Chirley, meu concunhado Roberto, meus sobrinhos e sobrinhas, pela confiança, incentivo, consolo, por muitas vezes emprestarem seus ombros e ouvidos para meus desabafos, pelos momentos de alegria e descontração proporcionados e por poder contar sempre com vocês;

À Escola Estadual Dr. Álvaro Guião na pessoa das professoras Ana Claudia Toledo dos Santos Prado e Alessandra Fernandes Rosa e dos alunos das turmas do $2^{\circ} \mathrm{G}$ e $2^{\circ} \mathrm{D}$, respectivamente e à Educativa - Instituto de Educação e Cultura na 
pessoa da professora Adriana do Valle Berganton e os alunos das turmas do $2^{\circ} \mathrm{A} \mathrm{e}$ $2^{\circ} \mathrm{B}$, por abrirem as portas e tornarem esse trabalho possível;

À profa. Dra. Alice Helena Campos Pierson, professora da UFSCar, por ter me auxiliado, durante uma disciplina que fiz com ela, na elaboração do questionário diagnóstico, instrumento de pesquisa que utilizei durante a coleta de dados;

Aos professores do grupo de Biofísica: Otaciro, Jabah, Ana Paula e Ricardo. Em especial à profa. Dra. Leila Maria Beltramini pelo aprendizado e amadurecimento na área de difusão de ciência proporcionado por meio de minha experiência junto ao CBME e por autorizar minha pesquisa com o jogo "Sintetizando Proteínas";

Aos técnicos do grupo de Biofísica: João, José Fernando, Andressa, Bel e Gislaine, pela competência, amizade, companheirismo e atenção;

Aos queridos amigos do Grupo de Biofísica: José Luiz (Zé), Assuero (Sussu), Joci, Cris Nordi (Cris), Fernando Melo (Fer melo, Cabeça), Leandro (Japonês, Go to), Priscila (Pri), Julio Damálio (rato), Lia, Ana Paula (Ana), Regiane (Rê), Ernani (Ceará), Daniel (Baiano), Alessandra (Alê), Susana (Su), Natália, Luiz Guilherme (Militar), Luiz (Argentino, Argelino), Célia (Celhoca), Débora (Deby’s, Debão), Fernanda (Fer), Ana Isabel (Bel), Carol, Kelven, Wânius, Nayara, Natália, Camila e Débora pela amizade, companheirismo e cumplicidade durante todos esses anos de convivência;

Aos queridos amigos da Coordenadoria de difusão do CBME: Luciano, Neusa, Márcia, Talles, Raphael, Alan, Erick, Fernanda, Cecília, Ana, Daniel, Marina, Marília, Vanessa, Bárbara, Lucas, Ribari, pela troca de experiências, pela companhia, pela amizade, pelos momentos de trabalho, parceria e também de alegria.

Ao CNPq e a Capes pelo apoio financeiro. 
"Sá me sinto digna das minhas asas se eu as utilizar para fazer as outros voarem.

(...)

"Fá muitas hienas e abutres na sociedade. Nãa esperem meita dos grandes animais. Esperem deles, sim. incompreensöes, rejeiçäes, calúnias e necessidade doentia de pader. Nãa as chama para serem grandes heróis, para terem seus feitas descritas nos anais da história, mas para serem pequenas andorinhas que sobrewaam anonimamente a sociedade amanda desconhecidas e fazenda par eles a que está aa seu alcance. Sejam dignos das suas asas. É na insignificância que se conquistam os grandes significados, é na pequenez que se realizam as grandes atos.

Augusto Cury 


\section{RESUMO}

Esse trabalho compreendeu a avaliação do impacto do jogo 'Sintetizando Proteínas' sobre o processo de ensino-aprendizagem de alunos do ensino médio e sua compreensão conceitual a respeito do tema 'proteínas', fundamentados na 'teoria sócio-interacionista' de Vygotsky. Os conceitos formulados pelos alunos foram coletados em três etapas diferentes: a primeira, anterior à aplicação do jogo, por meio de um questionário diagnóstico e uma pré-entrevista; a segunda, durante o jogo, por meio de gravações áudio-visuais; a terceira, posterior à aplicação do jogo, por meio de uma pós-entrevista. Os dados levantados pelo questionário diagnóstico permitiram detectar algumas tendências do pensar dos alunos com relação ao conceito de proteína: a) tendência em definir genericamente o papel das proteínas; b) tendência dos alunos em associar proteínas aos alimentos de origem animal; c) tendência em entenderem as proteínas apenas como 'construtoras' de tecidos, portanto uma função prioritariamente estrutural. A análise e interpretação dos dados referentes às pré e pós-entrevistas e das transcrições das gravações áudio-visuais nos mostraram que as interações ocorridas durante o jogo tiveram um importante papel na evolução de alguns conceitos antes incompreendidos pelos alunos. Dessa forma o jogo, enquanto um modelo que simula o processo de síntese protéica dentro da célula, proporcionou aos alunos experiências que os permitiram 'vivenciar' esse processo, estabelecendo uma ponte entre o abstrato e o concreto, possibilitando aos mesmos o alcance de níveis de desenvolvimento mais elevados e a evolução de conceitos antes incompreendidos.

Palavras chave: Proteínas. Síntese protéica. Jogo de regras. Concepções no ensino de Biologia. Vygotsky. 


\section{ABSTRACT}

The main goal of this study was evaluating the impact of the game 'Synthesizing Proteins' on the teaching-learning process of high school students and their conceptual understanding on the subject 'proteins', based on Vygotsky's sociointeractionist theory. The concepts of the students were collected in three different stages: before the application of the game, using a diagnostic questionnaire and a pre-interview; during the game, by means of audio-visual recordings; after the application of the game, by a post-interview. The data raised from the diagnostic questionnaire had allowed to detect some trends of students' thinking with regard to the protein concept: a) the trend in generically defining the role of proteins to the organism (human) b) students' trend in only associating proteins to foods of animal origin c) trend in only understanding proteins as 'tissue constructors', so a function primarily structural. The analysis and interpretation of data collected by pre- and post-interviews and the transcripts of the audio-visual recordings showed that the interactions occurred during the game had an important role in the evolution of some concepts that were previously misunderstood by students. Thus, the game as a model that simulates the process of protein synthesis inside the cell, allowed the students experience this process, establishing a bridge between the abstract and concrete and allowing them to achieve high levels of development.

Keywords: Proteins. Protein synthesis. Game of rules. Concepts in teaching biology. Vygotsky. 


\section{Lista de Figuras}

Figura 1 - Fotos da sede da Coordenadoria de Educação e Difusão do CBME, localizada na rua 9 de julho, 1205, ao lado do CDCC, em São Carlos, SP.

Figura 2 - Fotos do CDCC/USP, com destaque para sua área externa (Jardim da percepção) e o Observatório Astronômico e o Centro de Divulgação da Astronomia (CDA), instalados no campus I da USP de São Carlos.

Figura 3 - Desenho representativo do tabuleiro, parte integrante do jogo "Sintetizando Proteínas" ; (a) - numeração correspondente de cada etapa do processo de síntese de proteína, sendo que a etapa 1 ocorre no núcleo e não apresenta numeração (etapa 1 transcrição; etapa 2 - transferência do RNA mensageiro para o citosol; etapa 3 - tradução; etapa 4 - processamento protéico; etapa 5 - endereçamento da proteína); (b) - região destinada às peças, dependendo da etapa; (c) - região destinada ao monte de compras; (d) - região destinada ao descarte de cartões; (e) visão detalhada da membrana plasmática.

Figura 4 - "Carta-Objetivo". O mesmo possui 3 seções: (a) "A situação"; (b) "O mecanismo" e (c) "Seu objetivo".

Figura 5 - Peças de tabuleiro representativas de estruturas bioquímicas, com suas respectivas cores. (a) RNA mensageiro; (b) Estrutura primária da proteína e (c) Proteína processada.

Figura 6 - ' 'Carta-ação'. (a) A parte interna do cartão, com duas opções de ação, separadas pela conjunção "ou"; (b) Verso do cartão com os logotipos do CBME e do projeto "experimentoteca" do CDCC/USP (Centro de Difusão Científica e Cultural da Universidade de São Paulo.

Figura 7 - Vista frontal da escola, com destaque de sua bela escadaria e um busto do Dr. Álvaro Guião.

Figura 8 - Vista para a entrada principal da Educativa 


\section{Lista de Tabelas}

Tabela 3.1 - Tipos de cartas necessários para completar cada etapa do jogo

Tabela 4.1 - Avaliação de aspectos mensuráveis do jogo, por parte de professores de Biologia em cursos de extensão oferecidos pelo Centro de Biotecnologia Molecular Estrutural (CBME/CEPID/FAPESP).

Tabela 4.2 - Dados referentes ao levantamento do perfil dos alunos (65 alunos do Álvaro Guião e 68 alunos da Educativa), obtidos a partir das respostas à "conte um pouco sobre você", do questionário diagnóstico, em termos de porcentagem

Tabela 4.3 - Dados referentes ao levantamento das concepções dos alunos a respeito do tema 'proteínas', através da aplicação do questionário diagnóstico. Os dados foram organizados de forma a contemplar as categorias de reposta apresentadas pelos alunos a cada questão, bem como a freqüência com que cada categoria foi encontrada na análise dos questionários de cada turma envolvida no projeto. O público constou de 133 alunos (2DAG - 30; $2^{\circ} \mathrm{GAG}-35 ; 2^{\circ} \mathrm{AEDU}-33$ e $\left.2^{\circ} \mathrm{BEDU}-35\right)$

Tabela 4.4- Aluno James (EEAG): Respostas ao questionário diagnóstico e trechos das pré e pós-entrevistas.

Tabela 4.5 - Aluno Maurício (EEAG): Respostas ao questionário diagnóstico e trechos das pré e pós-entrevistas.

Tabela 4.6 - Aluno Michael (EEAG): Respostas ao questionário diagnóstico e trechos das pré e pós-entrevistas

Tabela 4.7 - Aluna Priscila (Educativa): Respostas ao questionário diagnóstico e trechos das pré e pós-entrevistas.

Tabela 4.8 - Aluno Paulo (Educativa): Respostas ao questionário diagnóstico e trechos das pré e pós-entrevistas.

Tabela 4.9- Aluno Junior (Educativa): Respostas ao questionário diagnóstico e trechos das pré e pós-entrevistas 
Tabela 4.10 - Aluna Kátia (Educativa): Respostas ao questionário diagnóstico e trechos das pré e pós-entrevistas..

Tabela 4.11 - Aluno Guto (Educativa): Respostas ao questionário diagnóstico e trechos das pré e pós-entrevistas.

Tabela 4.12 - Aluno Breno (Educativa): Respostas ao questionário diagnóstico e trechos das pré e pós-entrevistas.................. 


\section{Sumário}

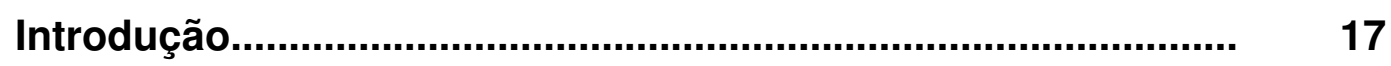

$1.1 \quad$ O sócio-interacionismo de Vygotsky................................................ 19

1.1.1 A formação de conceitos numa perspectiva Vygotskiana................. 20

1.1.1.1 A fase da agregação desordenada............................................... 22

1.1.1.2 A fase do pensamento por complexos........................................... 22

1.1.1.3 A fase do pensamento por conceitos............................................ 25

1.1.2 Os conceitos científicos e a "zona de desenvolvimento proximal

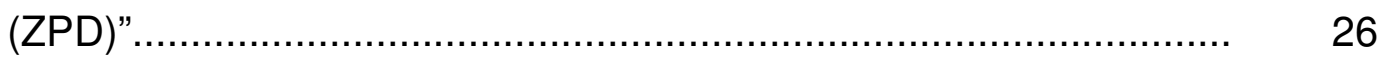

1.2 Os conceitos no ensino de Biologia............................................. 30

1.2.1 A importância de se conhecer as concepções trazidas pelos alunos............................................................................ $\quad 30$

1.2.2 Investigação sobre concepções alternativas em Biologia................. 32

1.3 A importância dos jogos para o ensino......................................... 36

1.3.1 Os jogos e o desenvolvimento................................................... 36

1.3.2 A dimensão lúdica do jogo........................................................ 39

1.3.3 O uso de jogos no ensino de Biologia........................................... 42

1.3.3.1 Jogos simbólicos: Manipulação de modelos físicos......................... 44

1.3.3.2 Jogos Simbólicos: Hole Playing Games...................................... 50

1.3.3.3 Jogos de Regras............................................................... 51

$1.4 \quad$ Questões de pesquisa......................................................... 54

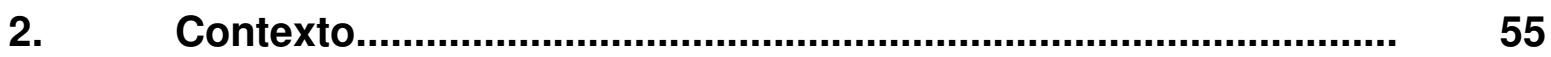

2.1 A parceria entre o CBME e o CDCC............................................. 57

2.2 A motivação para a criação do jogo "Sintetizando Proteínas"........... 60

2.3 A importância do estudo do tema 'proteínas' e os Parâmetros 61 Curriculares Nacionais do Ensino Médio

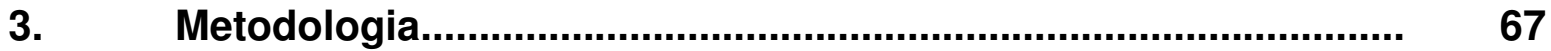

3.1 O jogo "Sintetizando Proteínas"...................................................... 69

3.1.1 Descrição dos componentes do jogo.............................................. 69

3.1.2 Descrição da dinâmica do jogo.................................................... $\quad 75$

3.2 A avaliação prévia do jogo por professores de Biologia.................... 78

3.3 A escolha das escolas participantes e contato com os professores. 80 
3.4 A primeira etapa: Levantamento das concepções dos alunos a respeito do tema "proteínas"..

3.4.1 O questionário diagnóstico: construção e aplicação........................... 83

3.4.2 A pré-entrevista: Seleção dos alunos e aplicação........................... 86

3.5 A segunda etapa: Aplicação do jogo com os alunos da amostra..... 88

3.6 A Terceira etapa: Verificação da aprendizagem e atuação dos tutores em sala de aula......................................................... 89

3.6.1 A pós-entrevista................................................................. 89

3.6.2 Aplicação do jogo com os demais alunos: A ação dos tutores......... 90

3.7 Forma de Análise dos dados.......................................................... 91

4. Resultados e Discussão........................................................ 93

4.1 A pré-avaliação do jogo com os professores.................................. 95

4.2 A avaliação do jogo com os alunos.................................................. 98

4.2.1 O perfil dos alunos.................................................................. 98

4.2.2 As concepções dos alunos com respeito à "proteínas".................... 101

4.2.3 Verificação da aprendizagem: Uma Comparação entre o questionário diagnóstico e as pré e pós-entrevistas dos alunos selecionados.

4.2.4 Análise das interações ocorridas durante o jogo............................. 140

4.2.5 Aplicação do jogo com as turmas: A ação dos tutores..................... 152

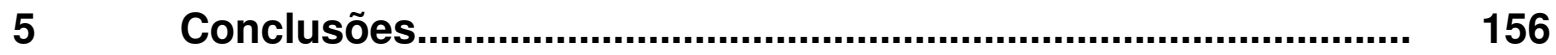

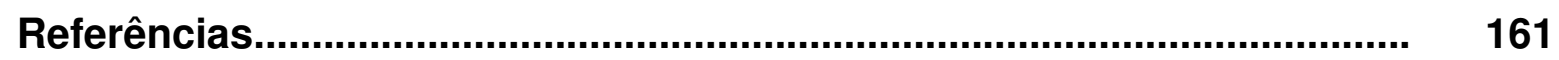

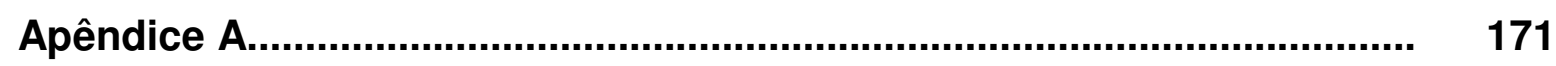

Apêndice B.............................................................................. 173

Apêndice C............................................................................. 179

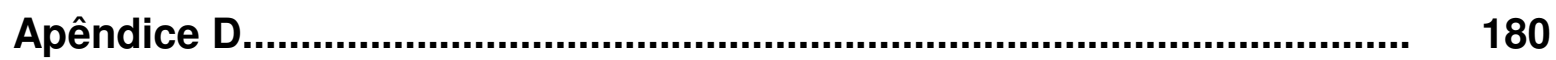

Apêndice E...................................................................................... 184

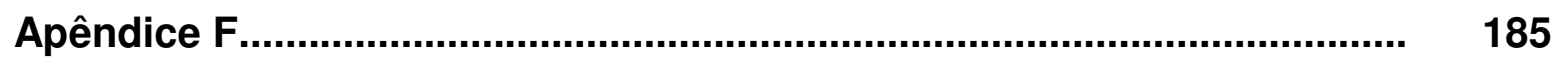

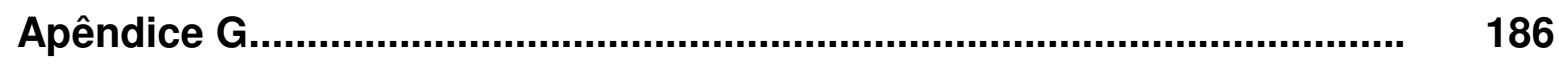

Apêndice H............................................................................ 213 



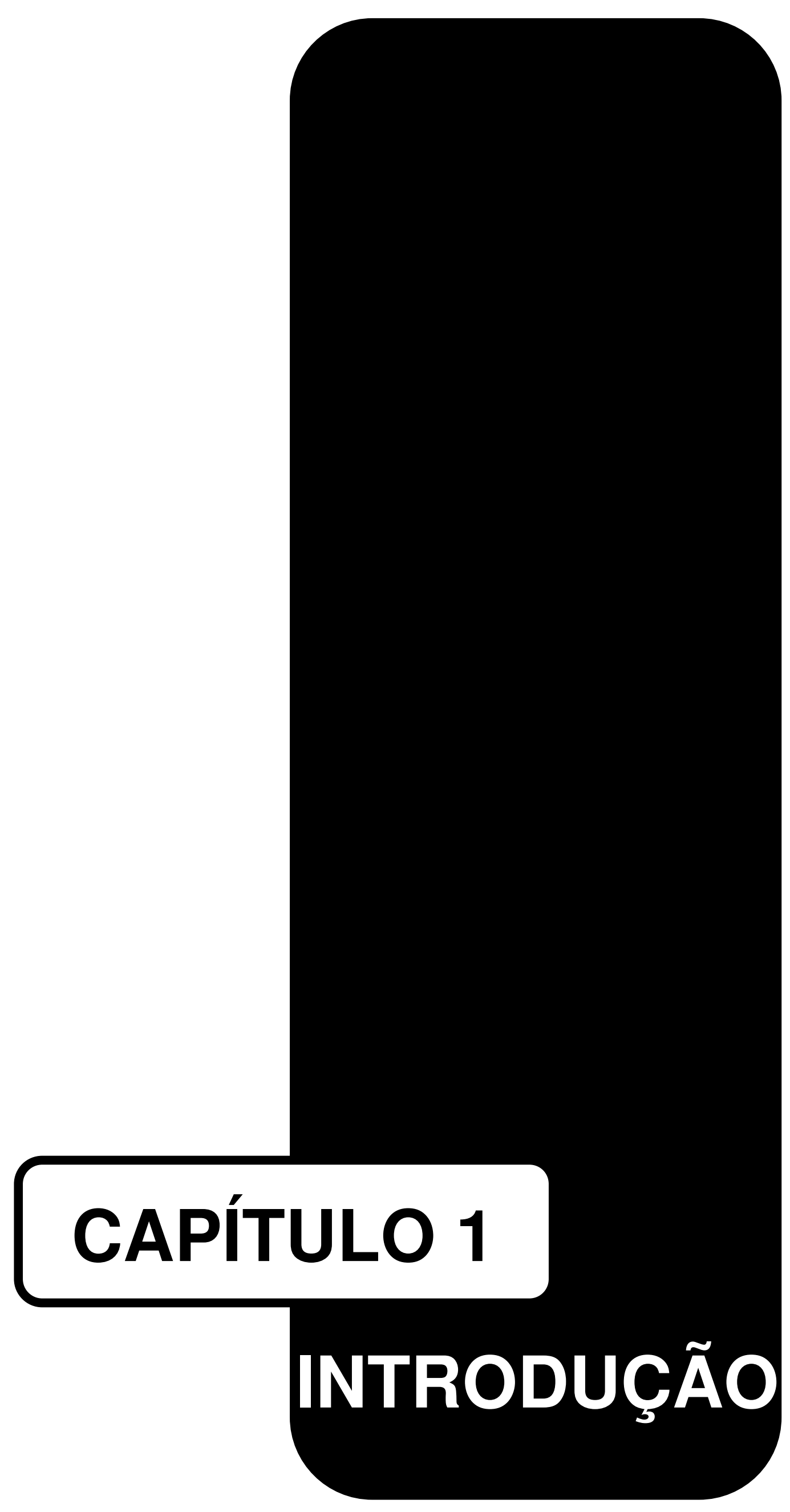



O pilar central desse trabalho foi a avaliação do impacto do jogo intitulado 'Sintetizando Proteínas' sobre o processo de ensino-aprendizagem de alunos do ensino médio e sua compreensão conceitual a respeito do tema 'proteínas'. Os conceitos formulados pelos alunos foram colhidos em etapas diferentes: a primeira, anterior à aplicação do jogo e a outra, posterior a sua aplicação. Durante a aplicação do jogo procuramos analisar as interações ocorridas entre os alunos. Ao analisar tais dados vimos que precisávamos entender não apenas a natureza dos conceitos trazidos pelos alunos, mas também como esses conceitos são construídos e qual a influência das relações interpessoais durante o jogo para a evolução desses conceitos no desenvolvimento mental dos alunos. Encontramos em Vygotsky o referencial que nos auxilia na análise mais apurada dos discursos dos alunos, bem como da influência das interações promovidas pelo jogo para o desenvolvimento dos mesmos. Neste capítulo discutiremos, ainda, a importância de se conhecer as concepções trazidas pelos alunos (seção 1.2) bem como a importância dos jogos para o processo de ensino-aprendizagem (seção 1.3).

\subsection{0 sócio-interacionismo de Vygotsky}

Vygotsky em sua obra intitulada 'Pensamento e Linguagem' (1991a), dedicou dois de seus capítulos ao estudo dos processos mentais que levam à formação dos conceitos espontâneos em um indivíduo, o papel do ensino sistematizado na formação dos conceitos científicos e a importância da linguagem e da cooperação na formação de ambos os conceitos. 
Para entendermos melhor, as seções 1.1.1 e 1.1.2 dessa dissertação foram reservadas ao estudo sobre a formação de conceitos, norteados pelas obras de Vygotsky (1991a, 1991b), com inserções dos trechos mais relevantes quando pertinentes, de modo a preservar suas idéias originais.

\subsubsection{A formação de conceitos numa perspectiva Vygotskiana}

Antes de entendermos como se dá a formação de conceitos por parte do indivíduo e os processos intermediários que o permeiam, iniciaremos por enunciar, de forma resumida, as principais conclusões da pesquisa de Vygotsky (1991a, p.49) e seus colaboradores para esse respeito, em que para eles

[...] o desenvolvimento dos processos que finalmente resultam na formação de conceitos começa na fase mais precoce da infância, mas as funções intelectuais que, numa combinação específica, formam a base psicológica do processo de formação de conceitos amadurece, se configura e se desenvolve somente na puberdade. Antes dessa idade, encontramos determinadas formações intelectuais que realizam funções semelhantes àquelas dos conceitos verdadeiros, ainda por surgir.

Assim, a formação de conceitos é um processo que acompanha as etapas de amadurecimento desde a infância, passando pela adolescência e atingindo a fase adulta, aumentando seu grau de complexidade, estimulado não somente por interações com o meio social, mas principalmente pelo domínio da linguagem, dos signos. Devemos, portanto, considerar, segundo Vygotsky ${ }^{1}$

[...] a formação de conceitos como uma função do crescimento social e cultural global do adolescente, que afeta não apenas o conteúdo, mas também o método de seu raciocínio. O novo e significativo uso da palavra, a sua utilização como um meio para a formação de conceitos, é a causa psicológica da imediata transformação radical por que passa o processo intelectual no limiar da adolescência.

\footnotetext{
${ }^{1}$ Ibidem, p. 51
} 
O instrumento utilizado por Vygotsky e seus colaboradores para estudar esse processo de formação de conceitos pelo indivíduo e tentar estabelecer um percurso genético do desenvolvimento do pensamento conceitual consistiu de 22 blocos de madeira, sólidos geométricos com cores, formas, alturas e larguras diferentes. O diferencial era que na parte inferior de cada bloco existia um nome, um signo que era característico de cada conjunto de blocos, cuja origem não estava na língua usual e sim em características peculiares aos blocos. Assim, desconsiderando a cor ou a forma dos mesmos, lag estava escrita em todos os blocos altos e largos, bik em todos os blocos baixos e largos, mur nos blocos altos e estreitos e cev nos blocos baixos e estreitos.

A dinâmica da atividade consistia em o examinador separar aleatoriamente um bloco dos demais (amostra), virá-lo de forma a expor o nome que o caracteriza e pedir que a criança criasse um conjunto com todos os outros blocos que pudessem ter o mesmo nome que o da amostra. Após a criança ter formado seu conjunto utilizando critérios próprios, o examinador virava um dos blocos do seu conjunto, de forma a comparar se realmente ela havia usado o critério correto. A cada erro, a criança repensava seu critério e tentava fazer um novo agrupamento. Os blocos que o examinador ia virando, para comparação com a amostra, permaneciam virados, de forma que à medida que mais blocos tinham seus nomes expostos, mais pistas eram oferecidas para a o aprimoramento dos critérios de agrupamento (VYGOTSKY 1991a, p.49)

Vygotsky e seus colaboradores perceberam, com os experimentos realizados, que o percurso até a formação de conceitos passa por três fases básicas, cada uma dividida em vários estágios, que veremos a seguir.

\footnotetext{
${ }^{2}$ Essa descrição do experimento feito por Vygotsky e seus colaboradores foi extraída da nota de rodapé da obra Pensamento e Linguagem (1991a, p. 49).
} 


\subsubsection{A fase da agregação desordenada}

Nessa fase, a criança agrupa os objetos sem qualquer fundamento, constituindo-se num amontoado de objetos desiguais, revelando uma extensão difusa e não direcionada do significado do signo (palavra desconhecida escrita nos objetos) a objetos naturalmente não relacionados entre si, constituindo-se numa visão global e bastante instável.

\subsubsection{A fase do pensamento por complexos}

Num pensamento por complexo, diferentemente da primeira fase, "as ligações entre seus componentes são concretas e factuais, e não abstratas e lógicas". Mas embora se distancie de um aglomerado, o que diferencia um complexo de um conceito é que "enquanto um conceito agrupa os objetos de acordo com um atributo, as ligações que unem os elementos de um complexo ao todo, e entre si, podem ser tão diversas quanto os contatos e as relações que de fato existem entre os elementos" (VYGOTSKY, 1991a, p. 53).

Vygotsky e colaboradores, na sua investigação, encontraram 5 tipos de complexos associados a essa fase da formação de conceitos:

- Complexo associativo: "Pode basear-se em qualquer relação percebida pela criança entre o objeto de amostra e alguns outros blocos" (VYGOTSKY, 1991a, p. 53). Essas relações podem variar desde semelhanças quanto a cor, 
forma, proximidade espacial, de forma que a palavra, para a criança, passa a ter uma conotação de 'família'.

○ Complexo por coleções: "Os objetos são agrupados com base em alguma característica que os torna diferentes e, conseqüentemente, complementares entre si" (VYGOTSKY, 1991a, p. 54). Nesse caso a criança poderia compor sua coleção baseado em contrastes, em que o critério pode ser os objetos terem cores diferentes, formas diferentes, tamanhos diferentes, em relação à amostra. No cotidiano podemos encontrar coleções como: xícara, pires e colher; um conjunto de faca, garfo, colher e prato e o conjunto de roupas que usa.

- Complexo em cadeia: Os critérios escolhidos para a composição do conjunto são como elos de uma corrente, em que cada elo é independente entre si e está unido somente com o elo anterior e posterior. Em outras palavras, se a amostra fosse um triângulo azul, num primeiro momento a criança agrupa blocos com formatos triangulares até que a cor vermelha de um deles lhe chama a atenção e ela passe a agrupar objetos na cor vermelha. Dessa forma os últimos blocos inseridos já não possuem semelhança com o primeiro, somente com o anterior e conseqüentemente com o posterior.

Veja que o complexo em cadeia difere-se do complexo associativo por não haver uma conexão com um elemento comum - núcleo do complexo. O complexo por cadeia não possui núcleo, há somente relações entre elementos isolados. Cada novo critério estabelecido corresponde um elo dessa corrente, em que cada elo possui características próprias.

- Complexo difuso: É semelhante ao complexo de cadeia, não fosse a fluidez entre os atributos de cada elo. Um exemplo seria uma criança ao tentar 
combinar objetos com um triângulo amarelo, poderia escolher trapezóides e triângulos, por possuírem vértices cortados. Os trapezóides poderiam levar a quadrados, que por sua vez levariam a hexágonos, posteriormente a semicírculos e finalmente a círculos (VYGOTSKY, 1991a, p. 56). Vemos, que embora sutil, há uma relação entre os atributos escolhidos, não sendo tão independentes quanto os atributos usados num complexo por cadeia.

- Pseudoconceito: Embora muitas vezes as generalizações feitas pela criança se assemelham aos conceitos dos adultos, em sua essência ainda é um complexo. Dessa forma, o fato de a criança associar ao triângulo amarelo (amostra) todos os triângulos, não quer dizer que tenha incorporado o conceito de triângulo e ter transferido esse atributo ao agrupar os objetos. A experiência de Vygotsky mostrou que a criança se orienta, na verdade, pela semelhança visível, formando apenas um complexo associativo, restrito a um determinado tipo de conexão perceptual (VYGOTSKY, 1991a, p. 56).

O pseudoconceito nesse caso constitui-se a ponte entre o pensamento por complexos, característicos da criança, e o pensamento por conceitos, iniciado durante a fase da adolescência. As suas semelhanças decorrem do fato de muito antes da criança operar por conceitos, ela se apropria da linguagem dos adultos, aprende uma série de palavras do universo adulto, mesmo que para ela possua significados diferentes.

Essa semelhança pode levar-nos a incorrer no erro de achar que a criança, em determinado nível de desenvolvimento cognitivo, está operando por conceitos, quando na verdade trata-se de um pseudoconceito. A origem desse erro, segundo Vygotsky, é que desde cedo a criança aprende um número muito grande de palavras do universo adulto, que para ambos (criança e adulto) tem o mesmo significado e a 
compreensão mútua entre eles cria a ilusão de que o conceito é fornecido pronto e acabado e de que não ocorre nenhum desenvolvimento.

\title{
1.1.1.3 A fase do pensamento por conceitos
}

\begin{abstract}
Em nosso estudo experimental dos processos intelectuais dos adolescentes, observamos como as formas primitivas de pensamento (sincréticas e por complexos) gradualmente desaparecem [...] e começam a formar-se os verdadeiros conceitos - esporadicamente no início, e depois com freqüência cada vez maior. No entanto, mesmo depois de ter aprendido a produzir conceitos, o adolescente não abandona as formas mais elementares; elas continuam a operar ainda por muito tempo, sendo na verdade predominantes em muitas áreas do pensamento. A adolescência é menos um período de consumação do que de crise e transição (VYGOTSKY, 1991a, p. 68, grifo nosso).
\end{abstract}

A adolescência é marcada por uma série de transformações, não somente de ordem física, mas psicológicas. É uma fase de transição entre a inocência e a maturidade, cheia de conflitos, de 'explosão' de sentimentos, uma fase de formação de uma identidade. É nessa fase que começa a formação dos conceitos verdadeiros, mas por ser uma fase transitória, não há um abandono do pensamento por complexo e sim uma substituição gradual entre os modos de pensar. Dessa forma, ao analisar adolescentes de uma mesma faixa etária, poderemos encontrar adolescentes que operam por complexos e outros que já formulam conceitos bem definidos.

A maior dificuldade encontrada pelos adolescentes, segundo $V_{y g o t s k y}{ }^{3}$, não está na formulação dos conceitos, mas em sua definição e aplicação.

O adolescente formará e utilizará um conceito com muita propriedade numa situação concreta, mas achará estranhamente difícil expressar esse conceito em palavras, e a definição verbal será, na maioria dos casos, muito

\footnotetext{
${ }^{3}$ Ibidem, p. 69
} 
mais limitada do que seria de esperar a partir do modo como utilizou o conceito.

$[\ldots]$

A maior dificuldade é a aplicação de um conceito, finalmente apreendido e formulado a um nível abstrato, a novas situações concretas que devem ser vistas nesses mesmos termos abstratos - um tipo de transferência que em geral só é determinado no final da adolescência. A transição do abstrato para o concreto mostra-se tão árdua para o jovem como a transição primitiva do concreto para o abstrato.

Percebemos então a importância do domínio da linguagem na formação de conceitos, uma vez que é através da relação que estabelecemos entre os signos (palavras) com os objetos e situações aos quais se referem, que se forma o que chamamos de 'significado'. Nesse contexto,

[...] um conceito se forma não pela interação das associações, mas mediante uma operação intelectual em que todas as funções mentais elementares participam de uma combinação específica. Essa operação é dirigida pelo uso das palavras como o meio para centrar ativamente a atenção, abstrair determinados traços, sintetizá-los e simbolizá-los por meio de um signo (VYGOTSKY, 1991a, p. 70).

\subsubsection{Os conceitos científicos e a "zona de desenvolvimento}

$$
\text { proximal (ZPD)" }
$$

Os conceitos científicos, introduzidos pelo ensino sistematizado, por tratarem-se de conceitos não espontâneos, tornam-se um grande desafio para os professores e educadores, a ponto de se perguntarem: "como estimular os alunos a construírem tais conceitos? Qual o papel do professor nesse processo?"

Um conceito científico, assim como qualquer conceito, deve ser construído, não assimilado como se fosse algo pronto e acabado, estimulando somente a memorização. Quando um aluno apenas memoriza um conceito, ao invés de 
construí-lo, abstraí-lo, terá dificuldade em aplicá-lo em outros contextos, não tendo para ele nenhum significado.

Entender como os conceitos científicos são construídos na mente do aluno e qual a inter-relação destes com os conceitos espontâneos é entender a relação entre o aprendizado escolar, sistematizado e o desenvolvimento mental da criança.

Nos estudos de Vygotsky (1991b) e seus colaboradores, eles levantaram 4 pontos importantes a respeito dessa relação entre aprendizado e desenvolvimento:

- O desenvolvimento das bases psicológicas para o aprendizado escolar não precede o próprio aprendizado espontâneo, mas interage continuamente com suas contribuições;

- O aprendizado é baseado em regras e requer disciplina, diferentemente do processo de desenvolvimento mental. Em geral o aprendizado precede o desenvolvimento;

- Cada matéria escolar atua como uma disciplina formal, cada uma facilitando o aprendizado das outras. As funções psicológicas por elas estimuladas se desenvolvem através de um processo complexo.

- Os anos escolares, em geral, constituem o período ótimo para o aprendizado de operações que exigem consciência e controle deliberado. O aprendizado dessas operações favorece o desenvolvimento das funções psicológicas superiores em fase de amadurecimento, se aplicando também aos conceitos científicos introduzidos pelo aprendizado escolar.

Mas o que Vygotsky considerou de importância fundamental para o estudo das relações entre aprendizado e desenvolvimento foi o papel da cooperação, seja pelo professor ou um parceiro mais capaz, no alcance de níveis de desenvolvimento cognitivos mais elevados. Os testes anteriormente usados para medir o nível de 
desenvolvimento de uma criança levavam em consideração somente as funções psíquicas já amadurecidas, testando até que grau de complexidade a criança conseguiria resolver sem auxílio, como se o nível de desenvolvimento fosse bem definido e a aprendizagem dependente desse nível. Em outras palavras, como se a aprendizagem de um determinado conceito dependesse somente do nível de desenvolvimento em que se encontra o aluno, caso contrário o mesmo não conseguiria aprender tal conceito. O que Vygotsky observou é que ao avaliarmos ou explorarmos somente as funções já maduras na criança, perdemos todo o processo de desenvolvimento mental, ao passo que atividades guiadas ou em cooperação fazem com que a criança atinja níveis mais elevados de desenvolvimento. Ele observou, por exemplo, que uma criança classificada pelos testes convencionais com idade mental de oito anos podia, em cooperação, resolver problemas elaborados para uma criança de doze anos, ao passo que sem cooperação não conseguiria ir além de problemas concebidos para crianças de nove anos. Essa discrepância entre os níveis de desenvolvimento é o que Vygotsky denominou de Zona de Desenvolvimento Proximal (ZPD). Dessa forma se o que queremos é descobrir as relações reais entre o processo de desenvolvimento e a capacidade de aprendizado de um indivíduo, temos que determinar pelo menos dois níveis de desenvolvimento.

Os níveis de desenvolvimento mental, segundo Vygotsky (1991b), podem ser divididos em: Nível de desenvolvimento real, em que o aluno atinge sem auxílio ou cooperação e nível de desenvolvimento potencial, só atingido mediante auxílio de um parceiro mais capaz, com cooperação. A região que compreende a distância entre esses dois níveis é chamada 'Zona de Desenvolvimento Proximal'. A mesma caracteriza-se como uma ferramenta por meio da qual educadores podem entender 
o curso interno do desenvolvimento, dando conta não somente dos processos já completados como também daqueles em processo de formação. Em outras palavras propicia o acesso não somente ao que já foi atingido através do desenvolvimento, como aquilo que está em processo de amadurecimento. Além disso, demonstrou que "aquilo que é caracterizado como zona de desenvolvimento proximal hoje, será nível de desenvolvimento real amanhã, ou seja, aquilo que uma criança pode fazer com assistência hoje, ela será capaz de fazer sozinha amanhã" (VYGOTSKY, 1991b, p. 98).

Considerando a 'zona de desenvolvimento proximal' como uma 'região' em que o desenvolvimento mental está em fase de amadurecimento, pode-se sugerir que um método de ensino adequado é aquele que se projeta à frente do desenvolvimento. Dessa maneira a construção de alguns conceitos científicos por parte dos alunos, por tratarem-se muitas vezes de conceitos bastante abstratos, de difícil compreensão, como por exemplo, os conceitos de átomo, molécula, célula e de processos bioquímicos, pode ser facilitado com o uso de modelos, atividades, em situação cooperativa (em grupo). 


\subsection{Os conceitos no ensino de Biologia}

\subsubsection{A importância de se conhecer as concepções trazidas pelos alunos}

Ao se tratar do ensino e aprendizagem de conceitos, educadores que seguem a linha construtivista têm destacado a importância de se conhecer os conhecimentos prévios dos alunos antes de introduzir qualquer nova informação, servindo de alicerce para planejar estratégias que possam auxiliar os alunos a resolverem seus conflitos cognitivos. Para a resolução desses conflitos cognitivos, a literatura da área propõe alguns modelos, dentre os quais destacamos o de mudança de perfis conceituais, proposto por Mortimer (MORTIMER, 1995). Esse modelo propõe não uma substituição de uma concepção por outra, uma ruptura, e sim a tomada de consciência de cada uma delas e dos argumentos que justificam o uso de uma ou de outra em determinados contextos.

A estes conhecimentos conceituais prévios a partir dos quais os alunos constroem o conhecimento dá-se o nome de concepções alternativas (GARCIAMILÀ, 2004). Segundo Santos (1991) os estudos sobre concepções alternativas têm crescido e se fundamentado cada vez mais, com inúmeras publicações que vão de teses a literatura e tem como principal propósito, "tornar-nos capazes de compreender o conteúdo das crenças e idéias que os alunos trazem para a instrução formal". Segundo os teóricos e investigadores, ignorar concepções trazidas pelos alunos é uma das principais causas da ineficácia da ação educativa. 
Pozo (1987 apud GARCIA-MILÀ, 2004), atribui algumas características às concepções alternativas:

○

$\bigcirc$

São construções pessoais dos alunos originadas em sua interação cotidiana com o mundo, formam-se de maneira espontânea e habitualmente preexistem ao ensino;

Apresentam incoerência científica, embora não cotidiana, já que muitas vezes antecipam fenômenos isolados observados pelo aluno em seu ambiente próximo ao transcurso das atividades cotidianas;

São estáveis e apresentam resistência à mudança, já que os alunos não as modificam apesar de esforços do professor para mudá-las;

Foram identificadas em crianças, adolescentes e adultos, inclusive em universitários em sua área de especificidade;

Mantém uma certa correspondência com as idéias expressadas por cientistas em épocas históricas menos evoluídas cientificamente;

Para Pozo et al. (1991 apud POZO, 1998), essas concepções alternativas

podem ter três origens: sensorial, cultural ou escolar.

Origem sensorial: concepções espontâneas. São adquiridas por meio das informações que os estudantes recebem através dos seus sentidos e formulam numa tentativa de dar significado às atividades cotidianas. São muito importantes para a interação com o mundo físico;

Origem cultural: concepções induzidas. São concepções que se originam no meio social do aluno e que impregnam suas próprias idéias. São adquiridas na escola, em interação com outras pessoas e através dos meios de comunicação. Grande parte das concepções biológicas dos alunos sobre a doença, a saúde, os seres vivos, etc. tem origem social;

Origem escolar: concepções analógicas. Em algumas áreas de conhecimento 0 aluno carece de conhecimentos específicos, espontâneos ou induzidos, razão pela qual a compreensão deve basear-se na formação de analogias, quer sejam geradas pelos próprios alunos, quer sejam induzidas pelo ensino. Por exemplo, grande parte do conhecimento químico dos alunos está baseada em modelos aprendidos na escola, embora assimilados as suas próprias idéias e crenças. Em muitos casos, seus conhecimentos prévios têm origem em aprendizagens escolares anteriores, embora costumem consistir em assimilações parciais ou deformadas do saber científico apresentado. Por isso, é necessário não somente uma boa seqüência de conteúdos, mas também em currículo que procure, explicitamente, a conexão das novas aprendizagens com aprendizagens anteriores.

A investigação sobre as concepções alternativas colocou em questão a eficácia do ensino por transmissão de conhecimentos previamente elaborados, e contribuiu de uma forma mais geral para levantar dúvidas sobre as visões simplistas da aprendizagem e do ensino das ciências, como a idéia de alguns docentes de que 
ensinar é uma atividade simples para o qual basta apenas conhecer a matéria e ter alguma experiência (CACHAPUZ et al., 2005).

Quando respeitamos as experiências vividas pelos alunos, suas concepções alternativas e as utilizamos como ponto de partida de discussões, em que o professor compara as diferentes concepções apresentadas pelos alunos e permite ou traz informações contraditórias, ou propõe situações para comprovar todas as concepções, estamos vinculando ciência à sociedade, como prevê Santos e Schneltzer (2000) em uma abordagem CTS.

\subsubsection{Investigação sobre concepções alternativas em Biologia}

Os alunos, na busca de explicações para muitos conceitos científicos, baseiam seus argumentos em suas experiências cotidianas, estabelecendo relações, embora muitas vezes simplistas ou ingênuas, entre o 'abstrato' e o 'concreto'. Na busca por trabalhos na literatura que explicitassem as concepções dos alunos sobre alguns temas em Biologia, em especial sobre 'proteínas' e 'síntese-protéica', não foi encontrado e sim apenas sobre conceitos que podemos considerar correlatos, como gene, DNA, informação genética. Nesse contexto, ao tentarem definir o que seria um 'gene', muitos alunos recorrem a concepções como “partes do pai e da mãe”, em alusão à herança genética (SMITH; WILLIANS, 2007), ou segundo a relação 'gene' e 'informação genética', afirmam que "genes são características" ou "genes determinam características" (LEWIS, 2000; LEWIS; LEACH; WOOD-ROBINSON, 2000a; LEWIS; WOOD-ROBINSON, 2000; 
MARBACH-AD, 2001; SMITH; WILLIANS, 2007; WOOD-ROBINSON; LEWIS; LEACH, 2000;). Com relação à composição química dos genes, poucos alunos fazem menção aos nucleotídeos, embora mencionem que o DNA seja composto por eles (MARBACH-AD, 2001), ou ainda apresentam respostas confusas ou superficiais como "genes são feitos de materiais ligados ao DNA" (LEWIS; LEACH; WOOD-ROBINSON, 2000a). Quando questionados a respeito da localização dos genes, muitos alunos admitem não saber (SMITH; WILLIANS, 2007), ou apresentam respostas genéricas do tipo "genes encontram-se nas células" ou "genes encontramse nos órgãos" (LEWIS; WOOD-ROBINSON, 2000; SMITH; WILLIANS, 2007). A importância dos genes, segundo os alunos, está relacionada à "preservação de características familiares ou individuais" (LEWIS; WOOD-ROBINSON, 2000) ou ainda a "determinação de características", inclusive de ordem comportamental (LEWIS; WOOD-ROBINSON, 2000; SMITH; WILLIANS, 2007).

Com respeito às discussões sobre 'cromossomo', alguns alunos o definem como sendo o que "carrega os genes" e sua importância deve-se ao fato de que "determina como as pessoas se parecem, características como a cor dos olhos, da pele..." (WOOD-ROBINSON; LEWIS; LEACH, 2000). Outros, porém, apresentam respostas como "cromossomo é um segmento de DNA" ou "cromossomos são compostos de DNA" (MARBACH-AD, 2001).

Com relação ao conceito de DNA, alguns alunos o referem como responsável pelo fluxo da informação genética, em respostas como "DNA transfere de uma geração à outra" ou "DNA é uma molécula que é responsável por transferir a informação genética" (MARBACH-AD, 2001). Outros remetem a características intrínsecas como "o que guarda todas as informações" ou às bases "C e G e todas 
as demais..." ou à replicação "indo como um Y quando estão separando" (WOODROBINSON; LEWIS; LEACH, 2000).

Analisaremos agora as concepções dos alunos com relação aos conceitos de gene, cromossomo e DNA no contexto de suas relações. São bastante comuns relações do tipo "cromossomos 'fazem' DNA", "cromossomos estão no DNA", "DNA envolve os genes", "cromossomos estão nos seus genes" ou "cromossomos 'fazem' os genes" (WOOD-ROBINSON; LEWIS; LEACH, 2000). Outras relações equivocadas apresentadas pelos alunos são encontradas quando os mesmos, no sentido de associar 'gene' e 'DNA' a produto gênico, atribuem a eles funções como "genes 'determinam' características" ou "DNA 'produz' proteína”, ao invés de 'codificam para' ou 'é traduzido em' (MARBACH-AD, 2001). No âmbito das relações dos conceitos de gene, cromossomo e DNA no contexto celular podemos perceber a falta de compreensão dos alunos, ao afirmarem que em um mesmo indivíduo "cada tipo de célula contém apenas a informação que necessita a fim de realizar suas funções"(LEWIS; LEACH; WOOD-ROBINSON, 2000b).

Outro tema que gera bastante conflito entre os alunos diz respeito ao conceito de 'digestão'. A maioria das concepções remete a termos como "quebrar" ou "dissolver" os alimentos. Assim, é bastante comum associações como "quebram os alimentos em partes no estômago" ou "dissolvem os alimentos no corpo ou estômago" (CAKICI, 2005). Segundo Cakici (2005), poucos alunos, no entanto, definem o produto dessa quebra. Para estes digerir significa "quebrar os alimentos em vitaminas, proteínas ou carboidratos no estômago". Percebe-se, entretanto, que a maioria dos alunos define digestão como um processo que ocorre somente no estômago, neste caso desconsiderando que o mesmo se inicia na boca, por meio da ação das enzimas produzidas pelas glândulas salivares. 
Outra preocupação apontada por Cakici (2005), diz respeito às concepções embutidas nas definições simplistas a respeito do processo de digestão, em outras palavras, os alunos quando relacionavam o processo de digestão a um processo de 'quebra', alguns mencionavam "extração de partes aproveitáveis dos alimentos" e "eliminação de partes indesejáveis" ou "absorção das partes digeridas dos alimentos pelo sangue". Já quando relacionam o processo de digestão a um processo de 'dissolução', não consideram a quebra dos alimentos em nutrientes a serem absorvidos pelo organismo, mencionam que os alimentos dissolvidos "desaparecem" no corpo (CAKICI, 2005).

O estudo das concepções dos alunos sobre determinado tema se expressa como um diagnóstico do processo de ensino-aprendizagem, um ponto de checagem que fornece informações valiosas sobre possíveis falhas nesse processo. Sabemos que o entendimento de temas básicos como 'proteínas' e o processo de sua síntese é essencial para o estabelecimento de conexões futuras a temas ligados ao estudo da Genética, como fluxo da informação genética, hereditariedade.

Os resultados em termos de concepções dos alunos, apresentados anteriormente, nos mostram a lacuna que existe entre o entendimento do conceito implícito no 'dogma central da Biologia Molecular', em que proteína é vista como um 'produto gênico', e o conceito de informação genética, que codificará para as características fenotípicas de um indivíduo, ao atribuírem as características genéticas aos genes e proteínas ao DNA (MARBACH-AD, 2001). Neste contexto, é que baseamos nossa proposta de pesquisa. Dessa forma nos propomos a analisar as concepções dos alunos sobre o tema 'proteínas' antes e depois da intervenção com um jogo didático, avaliando suas potencialidades em favorecer o processo de 
ensino-aprendizagem, através das interações promovidas entre os alunos e seu caráter lúdico.

\subsection{A importância dos jogos para o ensino}

\subsubsection{Os jogos e o desenvolvimento}

Comecemos por entender a relação da criança com o brinquedo. A criança em idade pré-escolar não planeja suas atividades a médio e longo prazo, ela está imersa em um universo de 'desejos realizáveis' e 'desejos não realizáveis'. Os desejos realizáveis são aqueles que podem ser satisfeitos imediatamente como chupar chupeta ou mamar, por exemplo. Os desejos não realizáveis são aqueles que não podem ser satisfeitos imediatamente, como o desejo de assumir o papel de mãe, dirigir um carro, fazer compras, cozinhar, se casar, e vêem no brinquedo uma perspectiva de realizá-los (VYGOTSKY, 1991b, p.106).

Nessa fase de desenvolvimento, uma das tarefas centrais está justamente na construção dos sistemas de representação, em que o papel chave neste processo é a capacidade de 'jogar com a realidade' (DIAS, 1996, p.47). Nesse sentido a autora diz que "o jogo simbólico constitui a gênese da metáfora, possibilitando a própria construção do pensamento e a aquisição do conhecimento". Acrescenta ainda que é através das múltiplas possibilidades de combinação proporcionadas pelo uso da metáfora, que fazemos a mediação entre realidade e pensamento. 
A imaginação criadora na criança surge na forma de jogo como instrumento primeiro de pensamento da realidade. De jogo sensório-motor evolui para jogosimbólico, ampliando sua compreensão do mundo. A partir do momento em que se pode imaginar, criar, o conhecimento deixa de ser limitado e o mundo inteiro pode estar presente dentro do pensamento (DIAS, 1996). Segundo a autora,

Representar é dar forma às experiências humanas significativas; é reapresentar, tornar novamente presente, presentificar vivências que, por sua importância, mereçam ser permanentemente lembradas. $O$ imaginário não se confunde com o real, ele é instrumento para a compreensão e a tomada de consciência do real.

Todos os jogos de regra, em sua essência, são jogos com situações imaginárias. Da mesma forma que nas situações imaginárias existem regras de comportamento, todo jogo de regras contém uma situação imaginária (VYGOTSKY, 1991b, p. 109). Em outras palavras, em uma situação imaginária em que a criança está representando o papel de mãe, existem regras de comportamento ao passo que suas ações estão limitadas às ações próprias de mãe. Um jogo de regra é antes de tudo uma simulação de uma situação real, portanto uma situação imaginária, baseado em regras pré-estabelecidas que determinam quais ações são permitidas dentro da proposta do jogo.

No entanto devemos tomar cuidado ao comparar jogos simbólicos (com situações imaginárias) com jogos de regras. No primeiro as regras são intrínsecas, tratam-se de padrões de comportamento e não combinações. No segundo as regras são explícitas, tratam-se de combinados arbitrários feitos pelo inventor do jogo e os jogadores aceitam por sua vontade, além de possuir um caráter coletivo (competição) em que só se pode jogar em função da jogada do outro (MACEDO, 1995). Para Vygostky (1991b, p. 107) o desenvolvimento do jogar com regras começa somente no final da idade pré-escolar e se desenvolve durante a idade escolar. 
Podemos então criar uma relação entre 0 jogo de regras e 0 desenvolvimento. Analisaremos essa relação tanto no âmbito do caráter imaginário do jogo como no âmbito de seu caráter coletivo. No âmbito do imaginário, o jogo, assim como o brinquedo, permite a realização de 'desejos não-realizáveis' por parte de quem joga. Assim, ao proporcionar a criança uma representação de algo que está à frente de seu desenvolvimento ou fora de seu alcance, segundo Vygotsky (1991b, p. 117), cria-se uma zona de desenvolvimento proximal da criança. No âmbito de seu caráter coletivo, em que o jogo promove a competição, desenvolve habilidades como "compreender melhor, fazer melhores antecipações, ser mais rápido, cometer menos erros ou errar por último, coordenar situações e ter condutas estratégicas" (MACEDO, 1995).

Macedo (1995) esclarece que o ato de competir em si não é bom nem ruim, apenas simula e os prepara para as constantes situações enfrentadas na vida real, pois "competir significa pedir simultaneamente a mesma coisa; no jogo de regras os jogadores fazem ao mesmo tempo um único pedido: ganhar". Vivemos em um mundo competitivo em que não se tem 'um para cada um' ou 'tudo para todos', sendo insensato fecharmos os olhos para a competição. Nesse contexto o grande vilão não é o ato de competir e sim a forma como se reage a ela, é o que se faz diante dela que modifica seu sentido (MACEDO, 1995). Em resumo, do ponto de vista do desenvolvimento, Vygotsky (1991b, p. 118) conclui que a criação de situações imaginárias, simbólicas, constitui-se como um meio para o desenvolvimento do pensamento abstrato. O desenvolvimento de regras conduz a ações, com base nas quais é possível separar 'trabalho' e 'jogo', fundamental para crianças em idade escolar. 


\subsubsection{A dimensão lúdica do jogo}

Pensemos na escola, no âmbito das relações pedagógicas, como um jogo, em que os jogadores (direção, professores e alunos) não sabem que estão jogando e por isso não se dão conta de seu desempenho nesse jogo. Nesse contexto, analisando esse jogo sob o olhar de um observador, segundo Macedo (1995), a escola constantemente propõe exercícios aos alunos, mas tira-os o sentido, seu valor lúdico. Ensina línguas, símbolos, cálculos, mas não ensina os alunos a 'ganharem' dentro dessas convenções, serem competitivos, principalmente diante do futuro mercado de trabalho. Enfim, as disciplinas escolares tornaram-se "jogos cujas regras nós ensinamos de forma esvaziada, portanto, sem valor" (MACEDO, 1995). Segundo Dias (1996), "as relações na escola estão congeladas e os conhecimentos ritualizados". Embora o jogo esteja presente na escola, trata-se de um jogo de regras pré-determinadas em que "a única ação permitida à criança é a obediência, ou melhor, a submissão".

Não se trata de transformar todos os conteúdos escolares em jogos e sim, mais do que isso, resgatar o 'espírito do jogo' na escola, que segundo Macedo (1995),

[...] pode significar para a criança que conhecer é um jogo de investigação por isso de produção de conhecimento - em que se pode ganhar, perder, tentar novamente, usar as coisas, ter esperanças, sofrer com paixão, conhecer com amor; amor pelo conhecimento no qual as situações de aprendizagem são tratadas de forma mais digna, filosófica, espiritual. Enfim, superior.

Dessa forma, Macedo, Petty e Passos (2005, p. 15) nos apresentam alguns indicadores que nos permitem inferir a presença do lúdico nos processos de aprendizagem ou desenvolvimento. Dessa forma, poderemos compreender 
resistências, desinteresses e limitações que tornam a escola sem sentido para a criança. Primeiramente os autores esclarecem que 'lúdico' não significa necessariamente uma atividade agradável a quem pratica. Se fosse só isso, nos tornaríamos "reféns das crianças ou condenados a praticar coisas engraçadas, mesmo que sem sentido". Acrescentam que "valorizar o lúdico nos processos de aprendizagem significa, entre outras coisas, considerá-lo na perspectiva das crianças. Para elas, apenas o que é lúdico faz sentido".

Ao refletir sobre o poder dos jogos e brincadeiras na escola, Lopes (2001) nos questiona que "se a criança brincando aprende, por que então não ensinarmos da maneira que ela aprende melhor, de uma forma prazerosa para ela e, portanto, eficiente?".

O primeiro dos indicadores apresentados por Macedo, Petty e Passos (2005, p. 16) é o 'prazer funcional'. A obrigatoriedade da freqüência à escola pode interferir no desejo de aprender dos alunos. Não perguntamos às crianças se queriam ser obrigadas a estudar na escola, nem se nesta ou naquela escola, ou se com estes ou aqueles professores, com os recursos ou condições oferecidas pela escola em questão. As crianças vivem o momento, não possuindo recursos cognitivos para pensar na perspectiva da escola como uma preparação para seu futuro profissional e social. Por isso o grande interesse pelos jogos. Na perspectiva dos alunos, não se joga com o intuito de aprender, ficar mais inteligente, simplesmente joga-se pelo prazer de jogar, porque é divertido, promove a interação com os colegas, mesmo que o contexto, muitas vezes, os leve a perder no jogo. No jogo eles são sérios, concentrados. Segundo Volpato (2002), a criança ao jogar ou brincar, ela, a brincadeira e o objeto tornam-se uma coisa só. 
As atividades escolares muitas vezes, pelo seu caráter repetitivo, pouco claro ou com pouco tempo para executá-las, tornam-se desagradáveis, sendo justificadas "por um interesse educacional que só faz sentido para os adultos, ainda que realizado para o 'bem' das crianças” (MACEDO; PETTY; PASSOS, 2005, p. 18).

O segundo indicador corresponde ao “desafio e surpresa". Desafiador no sentido de que deve oferecer certo grau de dificuldade que requeira do aluno superação. Surpresa ao passo que não se controla todo o resultado, tendo um caráter de investigação, de curiosidade, permitindo a liberdade de expressão de hipóteses. Um bom exemplo pode ser o uso de situações-problema (MACEDO; PETTY; PASSOS, 2005, p.18). O terceiro indicador refere-se às "possibilidades". Toda atividade proposta deve ser minimamente possível de se realizar, de forma que os alunos disponham de recursos internos e externos para isso. Os recursos internos dizem respeito a competências e habilidades e recursos externos referemse aos objetos, ao espaço, ao tempo e às pessoas. O quarto indicador é a “dimensão simbólica”. Isso quer dizer que "aquilo que se faz deve ter um correspondente, qualquer que seja, para a criança" (MACEDO; PETTY; PASSOS, 2005, p. 21). O símbolo nesse caso tem o papel de elo de ligação entre os conceitos científicos e o 'universo conceitual' dos alunos. O quinto e último indicador do lúdico nas atividades é a idéia de "expressão construtiva”. Esse indicador pressupõe os outros indicadores já citados, de forma que "a construção supõe prazer funcional, enfrentar e superar desafios, tornar possível e jogar com significações" (MACEDO; PETTY; PASSOS, p. 22).

Sabemos que é impossível transformar tudo em jogo, mas a idéia é ajudar nossos alunos a desfazerem a relação negativa que estabeleceram com as obrigações escolares. Pois "ser aluno é inevitável, mas aprender a divertir-se nessa 
condição é uma conquista importante para muitos". Através dos jogos, enquanto desencadeadores de ações, levar nossos alunos a aprender que os recursos mobilizados nas situações de jogos são propriedades deles, podendo ser transferidos para outros contextos (MACEDO; PETTY; PASSOS, p. 106).

\subsubsection{O uso de jogos no ensino de Biologia}

O jogo é sugerido pelo $\mathrm{PCN}+$, Brasil (2002) como uma estratégia para a abordagem de temas em Biologia, em que

Os jogos e brincadeiras são elementos muito valiosos no processo de apropriação do conhecimento. Permitem o desenvolvimento de competências no âmbito da comunicação, das relações interpessoais, da liderança e do trabalho em equipe, utilizando a relação entre cooperação e competição em um contexto formativo. $O$ jogo oferece o estímulo e 0 ambiente propícios que favorecem o desenvolvimento espontâneo e criativo dos alunos e permite ao professor ampliar seu conhecimento de técnicas ativas de ensino, desenvolver capacidades pessoais e profissionais para estimular nos alunos a capacidade de comunicação e expressão, mostrando-lhes uma nova maneira, lúdica, prazerosa e participativa de relacionar-se com o conteúdo escolar, levando a uma maior apropriação dos conhecimentos envolvidos.

Em especial, o estudo do tema proteínas (estrutural e funcional), bem como as relações entre DNA, RNA e proteína (dogma central da biologia molecular) em sala de aula, por sua complexidade, elevado nível de abstração e conseqüente dificuldade de compreensão por parte dos alunos, tem sido alvo de pesquisas e investigação em ensino de Biologia, uma vez que constitui a base para a compreensão de temas como 'código genético', 'hereditariedade', 'organismos geneticamente modificados' ou 'uso terapêutico de células tronco', por exemplo.

Antes de discutirmos com relação ao uso de jogos no ensino de Biologia, é interessante refletirmos como temas como 'DNA' e 'proteína' são abordados nos 
livros didáticos, já que os mesmos constituem-se como uma ferramenta bastante presente na sala de aula e em alguns contextos, a principal ferramenta. Em uma recente pesquisa, Silva e Leta (2006), investigando 10 livros didáticos de Biologia do ensino médio, entre os mais vendidos e utilizados pelos professores, obtiveram resultados surpreendentes. Segundo os autores, com relação ao conteúdo, apenas 4 livros fizeram referência a palavras-chaves relacionadas a 'DNA e evolução', ‘DNA e proteína' e 'DNA e transmissão da hereditariedade', assim como em somente um dos livros foi notado a preocupação em apresentar as inúmeras funções das proteínas. Outro dado importante e preocupante levantado por Silva e Leta (2006) foi que os livros de um modo geral "tendem a enfatizar conceitos relacionados à composição química e estrutura do DNA e da proteína. Por outro lado, pouco mencionam a correlação entre as duas biomoléculas". Quando o assunto é 'mutação', os livros "não apontam a importância das proteínas no processo de reparo ou na manutenção das mutações"... "também não há referências à construção do conceito de proteína" (SILVA; LETA, 2006)

As pesquisas têm demonstrado a preocupação em transformar a sala de aula em um ambiente propício à construção do conhecimento e mais do que isso, de uma forma lúdica e significativa para os alunos. Dessa forma a área de recursos instrucionais, no que se refere à proposição e avaliação de jogos, tem crescido bastante nas últimas décadas e com ela as diferentes formas de abordagem dos conceitos em Biologia frente ao ‘absolutismo' dos livros didáticos.

De acordo com sua essência, podemos dividir os jogos em "jogos simbólicos", em que incluem tanto atividades hands-on referentes à manipulação de modelos físicos representativos de moléculas ou processos bioquímicos quanto 
jogos de representação (RPG - Role Playing Game), e “jogos de regras”, que além de seu caráter simbólico incluem regras pré-determinadas e competição.

\subsubsection{Jogos simbólicos: Manipulação de modelos físicos}

Correspondem a atividades cuja proposta está em simular moléculas ou processos através de modelos que se diferem pelo tipo de material empregado. Podemos destacar trabalhos como o de Rogerson e Cheney (1989) que criaram um modelo à base de cartões representativos das estruturas bioquímicas e velcro ${ }^{\circledR}$ para simbolizar a ligação peptídica. Os autores sugeriram que o modelo fosse usado em atividades extraclasse, em cursos introdutórios de genética no ensino médio ou para níveis avançados de genética molecular. Fink (1990) apresentou um modelo para o estudo do processo de tradução do RNAm, utilizando para isso blocos de madeira para representar RNAm, uma placa de madeira para representar o ribossomo, destacando seus sítios de ligação, um amassador de batatas modificado representando o RNAt e velcro ${ }^{\circledR}$ para fixar o aminoácido ao RNAt. Brinner (1992), utilizando materiais de fácil acesso e de baixo custo como fios e zíperes, apresentou modelos para o estudo desde a estrutura do DNA, até a síntese protéica. Sprehn (1993) apresentou um modelo para o estudo do processo de síntese protéica em uma lousa de espuma e com o auxílio de peças de Lego $^{\circledR}$ e Velcro ${ }^{\circledR}$. Banta (1997), de uma forma bastante divertida e "gostosa", apresentou um modelo físico à base de elementos comestíveis para estudar processos como replicação, transcrição, síntese protéica, mitose, meiose e mutações. Lock (1997) apresentou algumas formas 
alternativas de abordagem de temas complexos e abstratos em Biologia, como cromossomos, síntese protéica e aglutinação, desde modelos físicos, painéis e até poemas.

Da mesma forma, Templin e Fetters (2002) propuseram um modelo físico a partir de peças de lego ${ }^{\circledR}$. Após a montagem do sistema (ribossomo, RNAm, RNAts e aminoácidos), os alunos, dispostos em grupos de 2 e 3 alunos tentavam sintetizar uma molécula de proteína a partir de um RNAm previamente montado. Num segundo momento o professor oferecia a cada grupo uma seqüência de nucleotídeos a partir da qual os alunos devem sintetizar uma nova proteína. Os autores sugerem algumas questões ao final da atividade, a fim de avaliar o conhecimento dos alunos. Kirkpatrick, Orvis e Pittendrigh (2002) propuseram dois modelos, "The Lego ${ }^{\circledR}$ Analogy Model (LAM)", para o estudo da tecnologia de seqüenciamento de DNA e o "The Small Town Analogy Method (STAM)", para o estudo de biologia celular. Esses modelos fazem parte de uma ferramenta educacional chamada "The Genomics Analogy Model for Educators (GAME)”, criada pela Universidade de Purdue (Indiana, EUA) que combina três tipos de atividades: a) um $C D$-Room, b) uma web-site e c) exercícios de laboratório. Corn, Pittendrigh e Orvis (2004) apresentaram uma extensão ao uso do GAME, propondo a discussão a respeito de "splicing alternativo". Nelson e Goetze (2004), utilizando materiais de baixo custo como fios coloridos, velcro ${ }^{\circledR}$ e grampos, propuseram um modelo para o estudo da estrutura de uma proteína. A aplicação do conhecimento foi proposta através de uma atividade em que levou os alunos a investigar como os 'bobs' auxiliam a formação dos cachos no cabelo das mulheres.

Com o intuito de auxiliar o entendimento da relação entre genótipo e fenótipo, Seipelt (2006) apresentou um modelo, baseado em um estudo de caso, o 
processo de produção de melanina e o albinismo. O modelo compunha-se de bolachas recheadas (representando "tirosinas"), cartões representativos dos papéis a serem desempenhados por cada aluno do grupo e outra série de cartões representando os tipos de mutações que ocorrerão durante o processo, com o propósito de dificultar a execução da dinâmica que era justamente a 'produção de melanina'. Atkins e Roderick (2006) aliaram arte, entretenimento e conhecimento ao apresentarem uma forma diferente e criativa de se estudar a estrutura de DNA. A proposta foi construir uma molécula de DNA a partir de contas de diferentes cores e formatos, representativos dos grupos fosfatos, açúcares e nucleotídeos. O trabalho final depende da criatividade de cada aluno, podendo variar entre um simples brinco a colares e braceletes. Turner (2007) propôs um modelo para o estudo da estrutura de uma enzima e o seu processo de desnaturação, utilizando materiais de fácil acesso como fio de telefone, elástico e tesoura. O autor sugeriu que o modelo fosse aplicado em grupo e passo a passo para que os alunos entendessem o que representava cada estrutura simbolizada no modelo. Baker, Jones e Hull (2007) propuseram um modelo para estudar a função do domínio de uma proteína, a base de fios de arame, contas e figuras geométricas de isopor simbolizando diferentes ligantes. Os alunos receberam um roteiro para a realização da atividade e após sua conclusão, foram avaliados através de um questionário.

Sabemos que a avaliação do impacto desses materiais no processo de ensino-aprendizagem é tão importante quanto a elaboração dos mesmos, afinal os professores e alunos são os principais agentes do processo. Não basta apenas serem atuais, bonitos, cheios de efeitos se não cumprirem com os propósitos para os quais os mesmo foram elaborados. Assim, alguns trabalhos não somente 
apresentaram propostas de modelos como também resultados de pesquisa, em termos de aplicação e avaliação em sala de aula.

Nesse contexto, Mensh e Rubba (1991) avaliaram a eficiência de um modelo, a base de PVC, chamado por eles de "Large hands-on”, usado para estudar o processo de síntese protéica e o papel de algumas enzimas no controle da transcrição e tradução do código genético, frente a aulas tradicionais de Biologia, em uma escola de ensino médio da Pensilvânia. Para isso selecionaram aleatoriamente dois grupos, um experimental, que teve aula com o modelo e um grupo controle, ao qual foi ministrado aulas tradicionais, embora atualmente não se use tal distinção de grupos em pesquisa social. Os pré- e pós-testes comparados entre as duas turmas mostraram, segundo Mensh e Rubba (1991), que em relação aos conteúdos conceituais não houve uma diferença significante entre os dois grupos. Em contrapartida, os conteúdos atitudinais em relação à Biologia e à Biotecnologia se mostraram mais evidentes no grupo experimental. Nesse sentido os autores concluíram que o uso do material não implicava em aumento de conceitos, mas implicava em aumento de atitudes, pois os alunos entendiam melhor o que estavam fazendo. No exame semestral final cada grupo recebeu uma questão extra (aberta) com relação ao processo de síntese protéica. Todos os alunos do grupo experimental responderam à questão e a maioria detalhou os processos de transcrição e tradução. Já do grupo controle somente metade respondeu à questão, cujas respostas foram curtas e não mencionaram processos como transcrição e tradução (MENSH; RUBBA, 1991).

Com o mesmo intuito, Rothhaar, Pittendrigh e Orvis (2006) propuseram a avaliação da eficiência dessa ferramenta GAME entre 182 alunos de ensino médio (idade entre 13-15 anos) de 7 escolas de Indiana, nos EUA. As ferramentas 
utilizadas para medir o conhecimento dos alunos consistiram de questionários, prétestes, pós-testes e o de atitude, usando escala Likert. Ambos os instrumentos foram previamente testados. Os resultados referentes à analogia com Lego ${ }^{\circledR}$ mostraram um aumento de conhecimento referente à genética e biotecnologia (de uma média de 9 pontos no pré-teste para 12 pontos no pós-teste). Em contrapartida, não houve uma mudança significativa de atitude com relação a esses temas, talvez devido a fatores como a seleção das turmas para a pesquisa ter sido feita baseada no interesse apresentado pelos professores e não de forma randômica. A hipótese apresentada pelos autores foi de que os professores voluntários pudessem apresentar algum interesse pelo tema e até já ter exposto seus alunos ao mesmo. Dessa forma esses alunos apresentariam um desempenho maior no pré-teste que as demais turmas. Outro fator que pode ter contribuído para essa pequena mudança de atitude, segundo os autores, pode ter sido em parte pelo curto período de tempo (1 semana) entre a intervenção e a aplicação do teste.

Beltramini et al. (2006) propuseram a elaboração e avaliação de um modelo físico para o estudo da estrutura do DNA e RNA e processos envolvidos (duplicação e transcrição). O mesmo é composto por peças plásticas de encaixe representativas das bases nitrogenadas, pontes de hidrogênio, e uma representativa do grupo fostato conectado com a pentose. Conectando-se as peças, o modelo permite a construção desde um nucleotídeo até as moléculas de DNA e RNA e assim simular os processos bioquímicos associados a essas moléculas. A avaliação do potencial do modelo na construção do conhecimento foi feita com 226 pessoas, em atividades oferecidas pelo Centro de Biotecnologia Molecular Estrutural (CBME/CEPID/FAPESP). Destas, 32 eram professores de ensino médio de diferentes áreas, 142 eram alunos de ensino médio, entre escolas públicas e 
privadas, e 52 graduandos do curso de Licenciatura em Ciências Exatas (IFSCUSP), da cidade de São Carlos, SP. Alguns aspectos relativos à aplicabilidade do modelo foram avaliados imediatamente após cada atividade, em que independentemente do nível educacional dos mesmos, obtiveram um nível positivo de aceitabilidade em todos os aspectos avaliados.

Para a avaliação do conhecimento dos alunos (total de 95) antes e depois da intervenção com o modelo, Beltramini et. al. (2006) aplicaram pré- e pós-testes, com intervalo de 2 semanas, contendo questões abertas. Ao analisar as respostas dos alunos aos questionários, categorizaram-nas em respostas "corretas", "parcialmente corretas", "erradas" e "não responderam". Dos 95 alunos, apenas 17 responderam corretamente que a molécula de DNA localiza-se dentro do núcleo de uma célula eucariótica e disperso no citoplasma em células procarióticas; 27 alunos mencionaram que o DNA está localizado no sangue, sem especificar um tipo de célula. Os autores atribuem esse tipo de concepção como oriunda da mídia, ao divulgar a coleta de sangue para exames de paternidade. Com respeito aos genes, apenas 16 alunos descreveram corretamente como sendo um segmento da molécula de DNA. De uma maneira geral, os autores perceberam uma diminuição nos número de questões erradas e não respondidas no pós-teste, em relação ao pré-teste. 


\subsubsection{Jogos Simbólicos: Role Playing Games ou RPG}

Alguns trabalhos aliaram arte à ciência, em proposições de atividades que lembram peças de teatro, em que os alunos, assumindo papéis de moléculas, simulam mecanismos bioquímicos como parte integrante do mesmo.

Nesse sentido, Biermann (1988) apresentou uma analogia entre o processo de síntese protéica com a construção de uma casa. Cada aluno teve que listar tudo o que era preciso para construir uma casa, desde recursos materiais, humanos e financeiros. Após os alunos terem feito a lista, foi feita a transposição didática. Pigage (1991) propôs uma atividade em que a sala de aula foi configurada para representar uma célula e os alunos, através de cartas, atores no processo de síntese protéica. Stencel e Barkoff (1993) apresentaram duas técnicas, chamadas por eles de "Técnica Barkoff" e "Técnica Stencel". Trata-se de atividades role-playing em que inicialmente os alunos sorteiam os papéis que definem a função de cada aluno. Alguns papéis correspondem a trincas de nucleotídeos, outros RNAt, RNA polimerase, ribossomo, etc. A atividade consiste em uma coreografia, inclusive com trilha sonora, em que sua execução exigia coordenação e cooperação. Rode (1995) apresentou uma proposta de atividade para simular o processo de síntese protéica através da simulação da formação do peptídeo do suco gástrico humano. Uma atividade em que os alunos assumindo papéis de moléculas envolvidas no processo de síntese protéica simulavam tanto o processo de transcrição quanto o de tradução. Para isso a sala de aula foi adaptada para representar uma célula e assim os alunos poderem entender onde ocorre cada processo. Crowther, Landon e Jacobitz (1997), propuseram uma atividade similar a de Pigage (PIGAGE, 1991). Transformaram um 
laboratório em uma célula, em que no hall de entrada havia representações para a membrana plasmática e o núcleo e dentro do laboratório o citoplasma. Cada bancada representava o Retículo Endoplasmático Rugoso e os alunos representavam Ribossomos e RNAs transportadores.

Da mesma forma, Asmus (2007) sugeriu uma atividade em que os alunos assumiriam o papel dos aminoácidos, através de cartões fixados em regiões específicas do corpo, por exemplo, um dos braços simbolizaria o "C" terminal e o outro o "N" terminal e 0 ato de dar as mãos entre os alunos, a ligação peptídica. Dessa forma o autor propôs a simulação de todas as estruturas de uma proteína.

\subsubsection{Jogos de Regras}

Como já explicado, é uma modalidade de jogos em que, além do caráter simbólico, constitui-se de um conjunto de regras pré-determinadas que delimitam as ações permitidas e não permitidas daqueles que aceitaram jogar. Como exemplo podemos citar alguns trabalhos, resumidos a seguir. Clements e Jackson (1998) desenvolveram um conjunto de jogos, baseados em cartões representativos das estruturas bioquímicas envolvidas na síntese protéica, sendo analisados ao longo dos três primeiros anos que foram incorporados ao currículo da disciplina "Introdução à Biologia (BLY 120)", oferecida no 1ำ ano do curso de Biologia da Universidade de Jacksonville (Jacksonville, FI, E.U.A.). Os jogos foram aplicados em grupos de 6 alunos, constando de 2 partes: a 'Transcrição', em que todos do grupo faziam o papel da RNA polimerase e a 'Tradução', em que um dos alunos era 
designado para fazer o papel do Ribossomo e os restantes assumiam os papéis de RNAs transportadores e juntos sintetizavam a proteína em questão. Segundo os autores, os alunos não somente jogaram o jogo, eles entenderam o processo. Desde a ordem em que ocorrem até os efeitos de uma mutação. Isto foi evidenciado através do desempenho dos alunos nos exames. Em particular, quando pedido aos alunos para transcreverem e traduzirem uma seqüência de DNA usando a tabela do código genético, cerca de $80 \%$ de todos os alunos, durante os três anos analisados, responderam corretamente.

Willmott (2001), por meio de um 'bingo', propôs a revisão dos conceitos de proteína e síntese protéica. Sua dinâmica consistiu em o professor lançar questões e os alunos marcarem em sua cartela caso contivesse a resposta.

A proposta de Lewis et al. (2005) foi um jogo cuja dinâmica baseou-se em cartões representativos das estruturas e organelas envolvidas na síntese protéica, em que os alunos num primeiro momento faziam uma revisão do conceito de célula e em seguida simulavam o processo propriamente dito.

Tivemos também o trabalho de Ash (2001), que apresentou uma dinâmica para facilitar o entendimento das relações entre genes e alelos. Cada grupo de alunos possuía um conjunto com três maços de cartas. Cada maço era composto por 6 cartões, cada um possuindo uma frase. A dinâmica consistia em os grupos formarem sentenças, combinando três cartões, um de cada maço, na ordem estabelecida pelas regras do jogo. Dessa forma a sentença representava o cromossomo e cada frase, seus alelos. A dinâmica permitia ainda a simulação de possíveis mutações, através da deleção, substituição ou inserção de palavras nas sentenças formadas. Pavan (2003) trabalhou com projetos em que propôs olimpíadas na área de genética para alunos do ensino fundamental, utilizando 
diferentes jogos, como jogos de tabuleiro, jogos de cartas e bingo. Seu objetivo principal foi a mobilização do ambiente escolar, envolvendo professores e principalmente os alunos, de modo a aprender a ciência de uma forma mais dinâmica e divertida.

A fim de mostrar a diversidade de recursos didáticos propostos nas pesquisas em ensino de Biologia podemos destacar ainda trabalhos como o de Vázquez (2003) que, na forma de uma revisão, apresentou uma série de ferramentas, entre softwares e vídeos, que podem ser utilizadas em sala de aula, tanto para ensino médio quanto superior, para o tratamento de biologia molecular e biotecnologia. Há também o trabalho de Araújo-Jorge et al. (2004), que apresentaram um projeto desenvolvido pela Fiocruz, um misto de ciência e educação. Desenvolveram uma série de atividades para o ensino de ciências, dirigidas a professores e estudantes de graduação, usando imagens geradas pelas pesquisas de biologistas celulares. Dentre as atividades encontram-se jogos, modelagem celular, além de atividades inovadoras apresentadas em praças públicas e favelas. E por último o trabalho de Davies (2005) que propôs o estudo de genética já a partir do ensino fundamental. A discussão começaria com 'família' e 'hereditariedade', levando os alunos a analisarem as diferenças entre as famílias e os colegas de classe. O autor apresentou exemplos de jogos e histórias que podem ser usadas de acordo com a idade, habilidade dos alunos e disponibilidade de tempo por parte do professor.

Nesse contexto, em que apresentamos a importância do lúdico no processo de ensino-aprendizagem, o papel do jogo como elemento motivador dentro do ambiente escolar, propomos estudar o impacto do jogo "Sintetizando Proteínas" no processo de ensino-aprendizagem de alunos do ensino médio. Esse jogo, 
desenvolvido pelo Centro de Biotecnologia Molecular Estrutural (CBME/CEPID/FAPESP) em parceria com o Centro de Divulgação Científica e Cultural de São Carlos (CDCC/USP), cujo mestrando é um dos autores, tem por objetivo colaborar na aquisição de competências voltadas para a investigação e compreensão científica e tecnológica, propostas pelos $\mathrm{PCN}+$ para o ensino de Biologia, Brasil (2002), uma vez que pode favorecer o reconhecimento, a utilização e a interpretação de um modelo explicativo e representativo de um sistema biológico.

\subsection{Questões de pesquisa}

À luz do referencial teórico de Vygotsky e dentro do contexto apresentado, o presente trabalho se propôs a investigar a contribuição do jogo 'Sintetizando Proteínas', no processo de ensino e aprendizagem de alunos do segundo ano do ensino médio, considerando as seguintes questões:

a) Que tipo de concepções prévias esses alunos tem ou trazem sobre proteínas?;

b) Qual a influência das interações ocorridas (aluno-aluno, mediador-aluno, aluno-jogo) no processo de aprendizagem dos alunos?;

c) Ao comparar os discursos dos alunos antes, durante e depois da aplicação do jogo, percebeu-se alguma evolução em termos conceituais? 


\section{CAPÍTULO 2}

CONTEXTO 



\subsection{A parceria entre o CBME e o CDCC}

\section{O Centro de Biotecnologia Molecular Estrutural (CBME/CEPID/FAPESP)}

Instituído a partir de $1^{\circ}$ de outubro de 2000 , o Centro de Biotecnologia Molecular Estrutural (CBME) $)^{4}$, um dos 10 Centros de excelência em Pesquisa, Inovação e Difusão (CEPID) patrocinados pela FAPESP, é uma iniciativa resultante da colaboração entre pesquisadores da Universidade de São Paulo (USP) no Campus de São Carlos, do Laboratório Nacional de Luz Síncrotron (LNLS) em Campinas, e da Universidade Federal de São Carlos (UFSCar). O objetivo central do CBME é realizar pesquisa básica e aplicada, bem como gerar desenvolvimento tecnológico e ensino de ciências em todas as áreas da biotecnologia que dependam da construção de moléculas baseada em estruturas, especificamente no desenho racional de novos compostos (fármacos, vacinas, pesticidas, herbicidas), e engenharia de proteínas.

Em especial, a Coordenadoria de Educação e Difusão do $\mathrm{CBME}^{5}$ (Fig. 1) se preocupa com o aspecto da educação e da difusão do conhecimento científico relacionado à Biotecnologia e Biologia Molecular Estrutural para a sociedade.

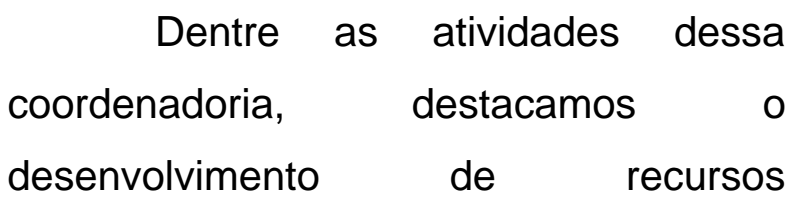
instrucionais, que incluem desde modelos físicos como "Construindo as moléculas da vida: DNA e RNA", e "Construindo

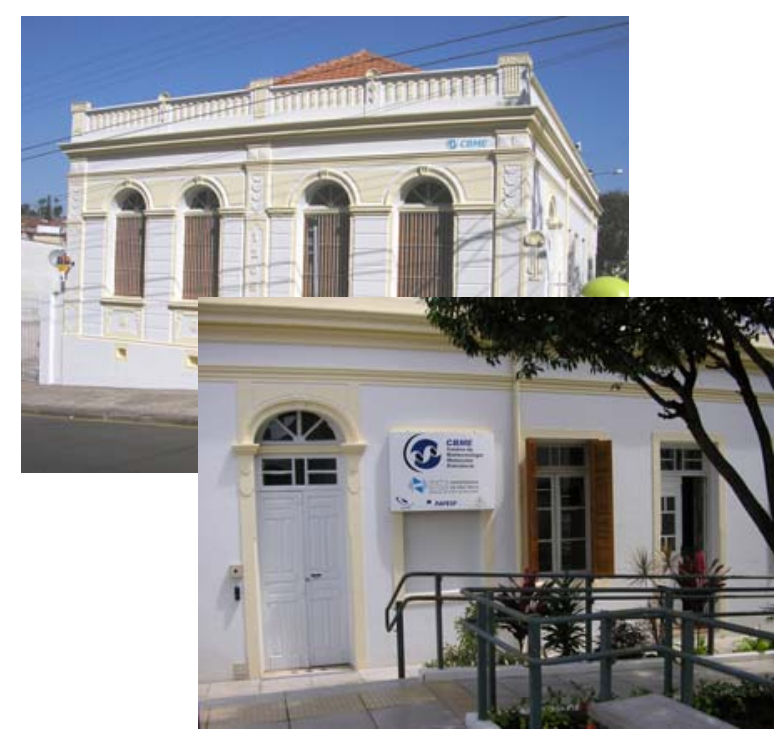

Figura 1 - Fotos da sede da Coordenadoria de Educação e Difusão do CBME, localizada na Rua 9 de julho, 1205, ao lado do CDCC, em São Carlos, SP.

Por: Felipe Moron.

\footnotetext{
${ }^{4}$ Conheça um pouco mais sobre o CBME por meio de seu site oficial, http://cbme.if.sc.usp.br.

${ }^{5}$ Para saber mais sobre as atividades desenvolvidas pela Coordenadoria de Educação e Difusão do CBME, acesse o site do "CBME informação", http://cbme.usp.br/cbmel, que além de informativo é interativo.
} 
Proteínas", multimídias como "A Célula Virtual" e "Ciência ao pé do ouvido", materiais de consulta como "Discos rotatórios de aminoácidos" e "Polígono de nucleotídeos", além de jogos educacionais como "Aminotrunfo", "Aminocartas", e um destaque para o jogo "Sintetizando Proteínas", objeto de estudo desse trabalho.

\section{O Centro de Divulgação Científica e Cultural (CDCC/USP)}

O Centro de Divulgação Científica e Cultural da Universidade de São Paulo $(\text { CDCC/USP) })^{6}$ (Fig. 2), iniciou suas atividades em 1980 e está sediado em um prédio histórico no centro da cidade de São Carlos, SP. É um Centro de Ciências vinculado à Pró-Reitoria de Cultura e Extensão Universitária, ao Instituto de Física de São Carlos e ao Instituto de Química de São Carlos, da Universidade de São Paulo. Integram ainda o CDCC um Observatório Astronômico e o Centro de Divulgação da Astronomia (CDA), cujo prédio está instalado no campus I da USP São Carlos.

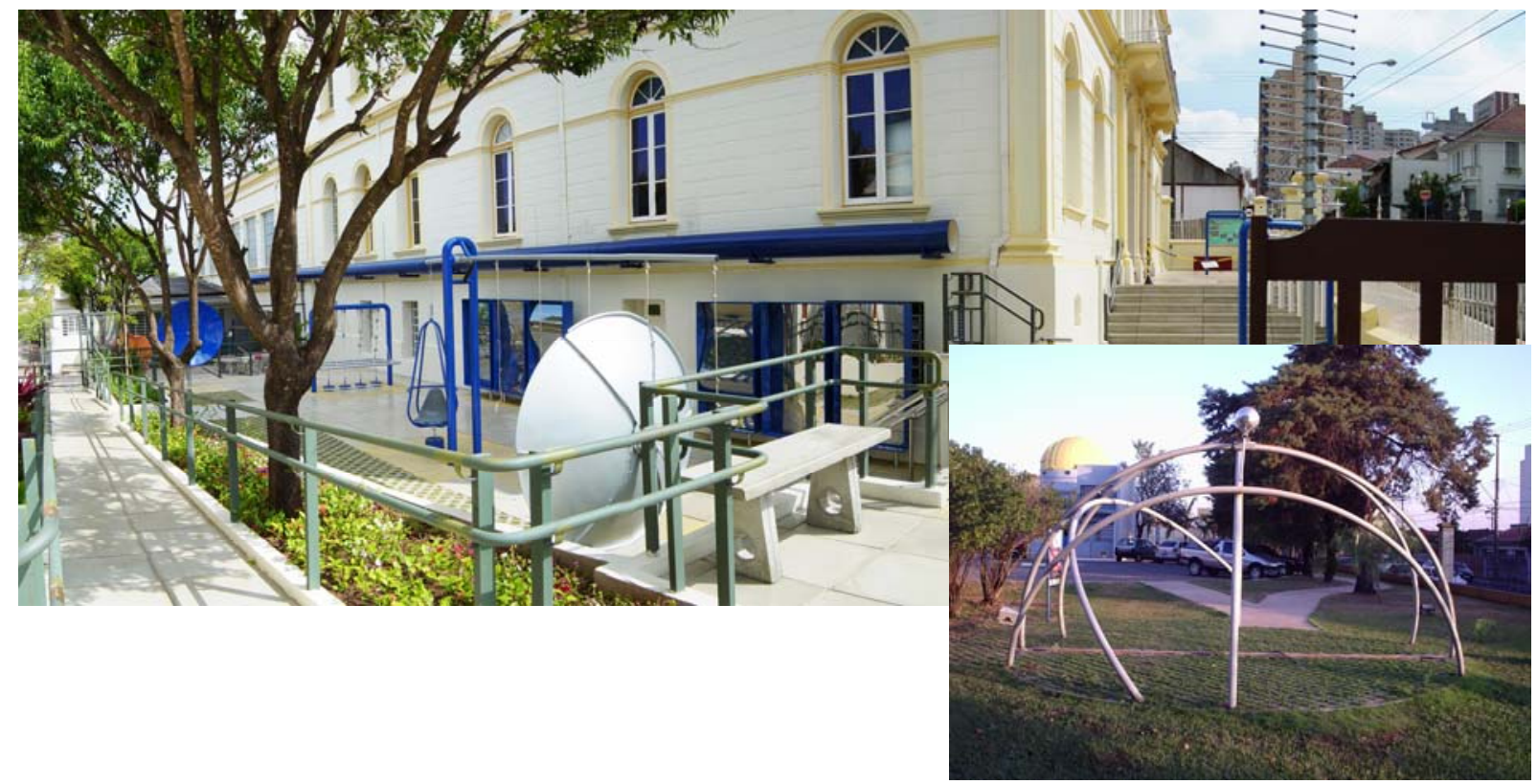

Figura 2 - Fotos do CDCC/USP, com destaque para sua área externa (Jardim da percepção) e o Observatório Astronômico e o Centro de Divulgação da Astronomia (CDA), instalados no campus I da USP de São Carlos.

Por: José Braz Mania

\footnotetext{
${ }^{6}$ Para maiores informações acesse o site oficial do CDCC: http://www.cdcc.usp.br/
} 
Este Centro de Ciências tem como finalidade desenvolver o interesse pelas ciências, ou seja, visa propiciar a integração dos indivíduos com o conhecimento científico. Assim, o CDCC desenvolve atividades diversificadas envolvendo programações educativas como mini-cursos, plantões de auxílio, visitas científicas monitoradas, capacitação para professores, observações de fenômenos de astronomia, olimpíada de ciências, atividades de informática e exposição interativa de física e exposição de ecologia. A divulgação cultural é realizada através de sessões de cineclube, exposições itinerantes, cursos de fotografias e atividades lúdicas.

Dentre os projetos desenvolvidos pelo CDCC destacamos, por exemplo, o projeto "Instrumentação para o ensino das ciências da natureza e da matemática", conhecido como "Experimentoteca do ensino médio", que conta com o apoio do CNPQ, VITAE e FINEP. Esse projeto visa o desenvolvimento de materiais didáticos para o ensino interdisciplinar a serem utilizados nas aulas de Física, Química, Biologia e Matemática do ensino médio em parceria com professores da rede pública de Ensino e participação de alunos (graduação e pós-graduação), com o intuito de criar um programa perene de pesquisas e produção de recursos para o Ensino das Ciências da Natureza e da Matemática com enfoque interdisciplinar. Atualmente a Experimentoteca do ensino médio possui 53 kits experimentais à disposição dos professores não somente da cidade de São Carlos, mas em todas as cidades assistidas pelo projeto.

A parceria entre o CBME e o CDCC fortaleceu-se no momento em que a sede da Coordenadoria de Educação e Difusão do CBME se instalou no prédio ao lado do CDCC e desde então tornou-se uma extensão do mesmo, realizando várias atividades em conjunto. Dessa parceria podemos destacar a incorporação de Kits 
dentro da temática 'Biologia Molecular e Biotecnologia' à Experimentoteca do ensino médio, como os Kits relacionados ao estudo da molécula de DNA (extração, estudo de sua estrutura molecular e de processos como duplicação, transcrição e tradução), o kit de "Expressão gênica e diferenciação celular" e "Biologia Molecular". O jogo "Sintetizando Proteínas" também é fruto dessa parceria e está inserido no projeto da Experimentoteca, com o kit "Síntese Protéica".

\subsection{A motivação para a criação do jogo 'Sintetizando Proteínas'}

Devido à complexidade de abordagem do tema 'síntese protéica' em sala de aula, recorrentemente citada por professores, e a conseqüente dificuldade de assimilação deste tema por parte dos alunos adolescentes, pelo seu alto nível de abstração, o jogo 'Sintetizando Proteínas', criado pelo Centro de Biotecnologia Molecular Estrutural (CBME/CEPID/FAPESP) em parceria com o Centro de Divulgação Científica e Cultural de São Carlos (CDCC/USP), foi desenvolvido com o objetivo de criar uma interface entre a teoria (abstrata) e a prática. O tema abordado está dentro do escopo da Coordenadoria de Educação e Difusão do CBME, que oferece suporte ao ensino de biologia molecular estrutural e biotecnologia. O jogo propõe o estudo da complexa teoria envolvida no processo de síntese protéica pelas células eucarióticas animais, por meio de uma atividade lúdica, em que o aluno sai da condição de expectador e passa a interagir com o objeto de estudo.

Nele os alunos podem simular os processos bioquímicos envolvidos na síntese protéica, como transcrição, transferência da molécula de RNA mensageiro 
do núcleo para o citosol, tradução, modificações pós-traducionais, e endereçamento da proteína a partir de uma situação-problema, onde o jogador tem como objetivo a síntese de uma determinada proteína humana. Além disso, o jogo proporciona situações nas quais podem ser discutidas questões como: "O que aconteceria com a célula, e conseqüentemente ao organismo, se uma daquelas proteínas a serem formadas não fosse expressa?", ou "Os processos de síntese das diferentes proteínas em nosso organismo ocorrem simultaneamente?" e finalmente, comparando-se as diferentes proteínas abordadas no jogo, levar os alunos a perceber a diversidade de suas funções, bem como a importância das proteínas ao organismo.

Não podemos deixar de mencionar que, aliado a essa ferramenta didática está o importante papel do professor enquanto mediador do processo de ensinoaprendizagem. Uma boa articulação entre a transposição didática e o direcionamento das discussões é imprescindível, sem elas o jogo deixa de ser uma ferramenta didática e torna-se um brinquedo, com função apenas de entretenimento.

\subsection{A importância do estudo do tema 'proteínas' e os Parâmetros Curriculares Nacionais do Ensino Médio.}

Nas últimas décadas, os avanços na área de Biologia Molecular e Biotecnologia tiveram seu foco direcionado não somente para o estudo do genoma, mas passaram a ter um olhar mais cuidadoso ao produto gênico, no caso as proteínas. Em 2000, em entrevista à revista Ciência Hoje, o americano Walter 
Gilbert, o mesmo que em 1980, juntamente com o britânico Frederick Sanger e o americano Paul Berg, ganhou o prêmio Nobel de Química pela criação de um método para a determinação da seqüência de nucleotídeos que compõe o DNA, apontou o rumo da pesquisa biológica para essa e as próximas décadas. Segundo Gilbert (2001),

[...] Os campos dominantes serão a genômica estrutural e a proteômica: conhecidos os genes, é preciso saber quais são e como interagem as proteínas que eles produzem. Estudos evolucionários a partir da genômica comparada também serão estimulados, e a bioinformática terá papel fundamental $[\ldots]$.

No Brasil será que foi diferente? Em 2003 foi publicada uma matéria no jornal "O Estado de São Paulo" cuja chamada dizia "O Brasil começa a entrar na era do proteoma". Essa matéria previa que

O seqüenciamento do genoma da bactéria Xylella fastidiosa, concluído em 6 de janeiro de 2000, pôs o Brasil no Primeiro Mundo da ciência. Agora, três anos e vários organismos seqüenciados depois, o País se prepara para entrar na era da proteômica, o estudo das proteínas, colocando-se ao lado dos países desenvolvidos. Vários laboratórios, divididos em duas redes, uma em São Paulo (em formação) e outra no Rio, iniciaram as primeiras pesquisas. Segundo os cientistas envolvidos nesses projetos, o Brasil tem tudo para repetir o sucesso que teve em genômica, embora o estudo do proteoma seja mais complexo. (SILVEIRA, 2003, grifo nosso)

É lógico pensarmos que o avanço da ciência só foi e é possível aliado ao avanço tecnológico e nessa área não está sendo diferente. Hoje em dia os cientistas dispõem de uma série de ferramentas tanto no campo da Biologia Molecular, na obtenção e preparação das amostras, quanto no campo da Física, com técnicas que permitem desde a determinação estrutural de uma proteína, caracterização, até o estudo de sua dinâmica. Dentre essas técnicas podemos citar: "Cristalografia", "Difração de Raio-X, "Ressonância Magnética Nuclear e eletrônica", "Dicroísmo Circular" e "Calorimetria".

Todo esse avanço, segundo Silva (2007), permitiu o surgimento de muitas linhas de pesquisa, com vários trabalhos nas áreas de caracterização do câncer, de doenças neurológicas (mal de Alzheimer), infecciosas e cardíacas. Outros trabalhos 
são voltados à caracterização de agentes infecciosos, "comparando o proteoma de cepas patogênicas com não patogênicas de microrganismos, o que pode auxiliar no desenvolvimento de métodos diagnósticos e de agentes terapêuticos". Na área vegetal, a autora destacou os trabalhos de análise proteômica em plantas economicamente interessantes como o milho, trigo, arroz e batata, a identificação das principais proteínas expressas pela Xyllela fastidiosa durante o processo de infecção de plantas de citro e muitas outras.

Isso nos faz refletir a importância dos alunos compreenderem o papel das proteínas para que possam refletir criticamente sobre esses avanços científicos, ao invés de simplesmente assimilá-los como sendo absolutos. Onde fica a Educação em Biologia nesse processo? Qual seu papel e importância?

Segundo os Parâmetros Curriculares Nacionais (PCN) para o ensino médio, Brasil (1999, p. 219), na parte destinada a 'Ciências da natureza, matemática e suas tecnologias', no que se refere aos 'conhecimentos de Biologia',

O desenvolvimento da Genética e da Biologia Molecular, das tecnologias de
manipulação do DNA e da clonagem traz à tona aspectos éticos envolvidos
na produção e aplicação do conhecimento científico e tecnológico,
chamando à reflexão sobre as relações entre a ciência, a tecnologia e a
sociedade. Conhecer a estrutura molecular da vida, os mecanismos de
perpetuação, diferenciação das espécies e diversificação intraespecífica, a
importância da biodiversidade para a vida no planeta são alguns dos
elementos essenciais para um posicionamento criterioso relativo ao
conjunto das construções e intervenções humanas no mundo
contemporâneo. Com isso percebe-se a necessidade de um ensino que acompanhe essa evolução, esses avanços científicos e tecnológicos, de forma que a sala de aula passe a abrir espaço para discussões que vão além do currículo escolar, além do ensino formal, sistematizado, preocupado não somente com a assimilação de conceitos por parte dos alunos, mas em oferecer subsídios para que os mesmos tenham autonomia e possam participar mais ativamente do mundo em que vivem, um ensino voltado para a inclusão dos alunos na sociedade. 
A proposta dos PCN+, Brasil (2002, p. 42), é um ensino por competências, em que se propõe a organização do conhecimento

a partir não da lógica que estrutura a ciência, mas de situações de aprendizagem que tenham sentido para o aluno, que Ihe permitam adquirir um instrumental para agir em diferentes contextos e, principalmente, em situações inéditas de vida.

Dessa forma, a sugestão dos PCN+ é um currículo de Biologia que não segue a seqüência programática como tradicionalmente estamos acostumados, mas organizado de forma que os conteúdos a serem ministrados aos alunos durante o ensino médio estariam agrupados em seis temas estruturadores: "Interação entre os seres vivos", "Qualidade de vida das populações humanas", "Identidade dos seres vivos", "Diversidade da vida", "Transmissão da vida, ética e manipulação gênica", “Origens e evolução da vida” (BRASIL, 2002, p. 49)

Destacaremos agora o tema estruturador "Identidade dos seres vivos" por compreender o estudo das proteínas e da síntese protéica, tema central de nossa investigação, e que é subdividido em quatro unidades temáticas que propõem competências a serem desenvolvidas. Com relação ao tema proteínas, a unidade 'A organização celular da vida' propõe a representação de diferentes tipos de células a partir da utilização de instrumentos ópticos, observação de fotos e representações e pesquisa em textos científicos. A unidade 'As funções vitais básicas' propõe a análise de imagens e representações relacionadas aos diferentes tipos de transporte através da membrana. Com relação ao tema síntese protéica, a unidade 'DNA: a receita da vida e seu código' propõe (a) localizar o material hereditário em células de diferentes organismos, a partir de fotos e representações esquemáticas, (b) estabelecer relação entre DNA, código genético, fabricação de proteínas e determinação das características dos organismos, (c) analisar esquemas que relacionam os diferentes tipos de ácidos nucléicos, as organelas celulares e o 
mecanismo de síntese de proteínas específicas. Além dessas citadas temos a unidade 'Tecnologia de manipulação do DNA', que embora não esteja diretamente ligada ao tema 'proteína e síntese protéica' e, portanto ao jogo, pode ser explorada pelo professor. O mesmo pode sugerir leituras e discussões a respeito das técnicas de manipulação genética e o papel da engenharia genética na produção de alimentos mais nutritivos e resistentes a herbicidas. Pode ainda, levar os alunos a discutirem sobre alguns produtos originários da manipulação genética que já estejam circulando no mercado brasileiro, suas vantagens, desvantagens, benefícios e malefícios tanto a população quanto ao meio ambiente.

Deve-se ressaltar ainda que para que seja possível uma 'comunicação' entre os temas estruturadores e a formação crítica do aluno, segundo o PCN, Brasil (1999, p. 225), deve haver uma inter-relação entre os conteúdos de Biologia, de forma que temas básicos, como o estudo das 'proteínas', do processo de sua síntese e sua relação com o DNA, são importantes para compreensão da 'genética', da 'hereditariedade', que por fim formam a base para futuras discussões sobre os avanços científicos nas áreas de Biologia Molecular e Biotecnologia e suas implicações à sociedade.

A descrição do material genético em sua estrutura e composição, a explicação do processo da síntese protéica, a relação entre o conjunto protético sintetizado e as características do ser vivo e a identificação e descrição dos processos de reprodução celular são conceitos e habilidades fundamentais à compreensão do modo como a hereditariedade acontece.

[...] é possível ao aluno relacioná-los às tecnologias de clonagem, engenharia genética e outras ligadas à manipulação do DNA, proceder a análise desses fazeres humanos identificando aspectos éticos, morais, políticos e econômicos envolvidos na produção científica e tecnológica, bem como na sua utilização; o aluno se transporta de um cenário meramente científico para um contexto em que estão envolvidos vários aspectos da vida humana. 


\section{CAPÍTULO 3}

METODOLOGIA 



\subsection{O jogo "Sintetizando Proteínas"}

Durante o período de graduação, o mestrando atuou junto à Coordenadoria de Educação e Difusão do CBME na elaboração de recursos didáticos para o ensino de Biologia Molecular e Biotecnologia, para diferentes níveis educacionais. Dentre esses materiais destacamos sua participação na criação do Jogo 'Sintetizando Proteínas', uma parceria entre o CBME e o CDCC. Desde a concepção de sua idéia, o jogo sofreu, por parte de seus autores e colaboradores, importantes modificações a fim de adaptá-lo cada vez mais à realidade de sala de aula. No início a única idéia que tínhamos era que o jogo seria veiculado através de um tabuleiro. A partir dessa idéia e através de reuniões periódicas, começamos a discutir como seria sua dinâmica, suas regras e sua relação com o tempo de duração de cada partida. Assim, em suas primeiras versões, bastante carregado de etapas e regras, a média de duração de cada partida era de $2 \mathrm{~h}$, sendo que em suas últimas versões esse tempo não ultrapassou 1h. Nesse processo, a avaliação do protótipo do jogo junto aos professores de Biologia foi de fundamental importância pois os mesmos levantaram problemas reais a serem corrigidos antes de aplicá-lo aos alunos.

\subsubsection{Descrição dos componentes do jogo}

Este jogo é composto por um tabuleiro contendo o desenho de uma célula eucariótica animal em corte; cartas representativas das proteínas a serem formadas, 
contendo uma situação-problema; peças de tabuleiro representativas dos componentes do jogo, como RNA mensageiro, estrutura primária da proteína e proteína processada; cartas contendo instruções necessárias para o cumprimento de cada etapa do jogo e que são responsáveis pela dinâmica do mesmo; acompanha também materiais adicionais como 4 canetas hidrográficas coloridas (amarela, vermelha, verde e azul), um lápis borracha e um apontador.

O tabuleiro compõe-se de um desenho representativo do corte de uma célula eucariótica animal (fig.3), com os nomes característicos de cada organela, ou região, estampados no mesmo, didaticamente desenvolvido e adaptado para cumprir com os propósitos do presente jogo. O jogo é dividido em etapas devidamente numeradas no tabuleiro, para a orientação dos participantes (com exceção da etapa 1, que ocorre no núcleo da célula) (fig.3a). A primeira etapa, no núcleo da célula, corresponde ao processo de transcrição, portanto de formação do RNA mensageiro; a segunda etapa corresponde à saída do RNA mensageiro do núcleo para o citosol; a terceira, o processo de tradução, culminando com a formação da estrutura primária de cada proteína; a quarta etapa 'processar proteína' é representada de modo único e simplificado, simbolizando processos como o enovelamento da molécula, adição de substratos, entre outros; a quinta e última etapa correspondendo ao endereçamento da proteína ao local aonde ela irá "atuar". Servindo como um guia, cada uma das etapas descritas acima é representada por um desenho estampado no tabuleiro que tem o mesmo formato das peças utilizadas pelos participantes, a fim de que cada participante ou grupo saiba onde deve colocar cada peça, de acordo com a etapa vigente (fig.3b).

O tabuleiro possui ainda três regiões especiais: a primeira destinada à compra de cartas, portanto reservada ao maço de compras (fig.3c), a segunda 
reservada ao depósito de cartas descartados durante as rodadas do processo (fig.3d) e a terceira, localizada na membrana da célula, representada por uma lupa, indicando com maiores detalhes a bicamada fosfolipídica da membrana celular e algumas proteínas de membrana (desenho fora de escala, apenas representativo) (fig.3e).

Além do tabuleiro, o jogo possui 61 cartas representativas dos objetivos,

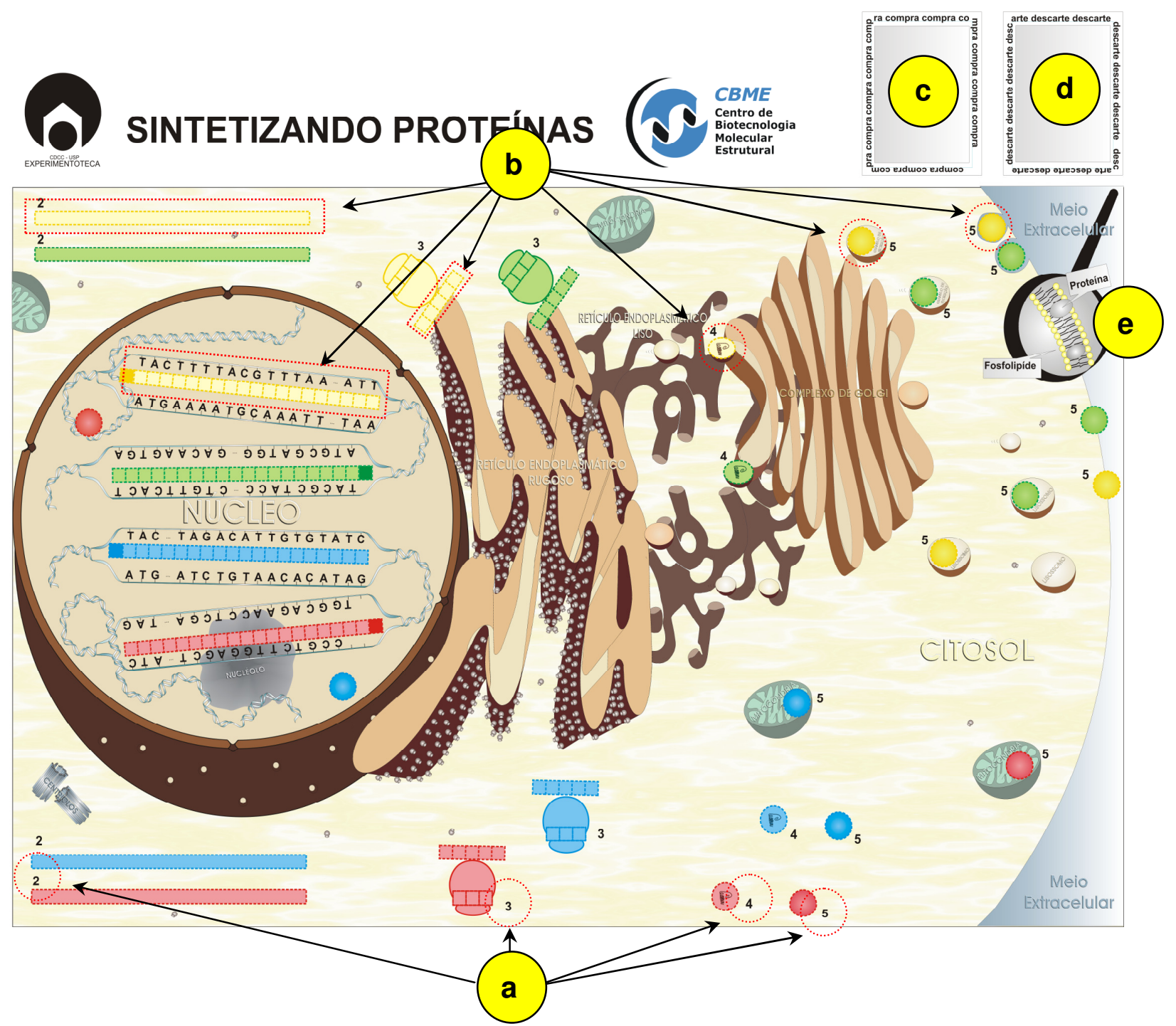

Figura 3. Desenho representativo do tabuleiro, parte integrante do jogo "Sintetizando Proteínas" ; (a) - numeração correspondente de cada etapa do processo de síntese de proteína, sendo que a etapa 1 ocorre no núcleo e não apresenta numeração (etapa 1 - transcrição; etapa 2 transferência do RNA mensageiro para o citosol; etapa 3 - tradução; etapa 4 - processamento protéico; etapa 5 - endereçamento da proteína); (b) - região destinada às peças, dependendo da etapa; (c) - região destinada ao monte de compras; (d) - região destinada ao descarte de cartões; (e) visão detalhada da membrana plasmática. 
denominadas "cartas-objetivo" (fig. 4), a serem cumpridos por cada aluno ou grupo durante o desenvolvimento do jogo, que tem como objetivo final a síntese de uma proteína específica. Essas cartas apresentam três seções: "A situação", em que a proteína a ser formada é inserida em um contexto ligado ao cotidiano dos alunos, na forma de uma situação-problema, de forma que a resolução desse "problema" depende da síntese dessa determinada proteína (fig. 4a); "Mecanismo", que descreve de forma bastante sintética e simples o mecanismo biológico por meio do qual a proteína em questão se formará, detalhando etapas do processo e intermediários de reação (fig. 4b); "Seu Objetivo”, baseado na situação-problema e no mecanismo biológico, indicando qual proteína deverá ser formada e para onde deve ser encaminhada quando atingir a quinta etapa do jogo (fig. 4c).

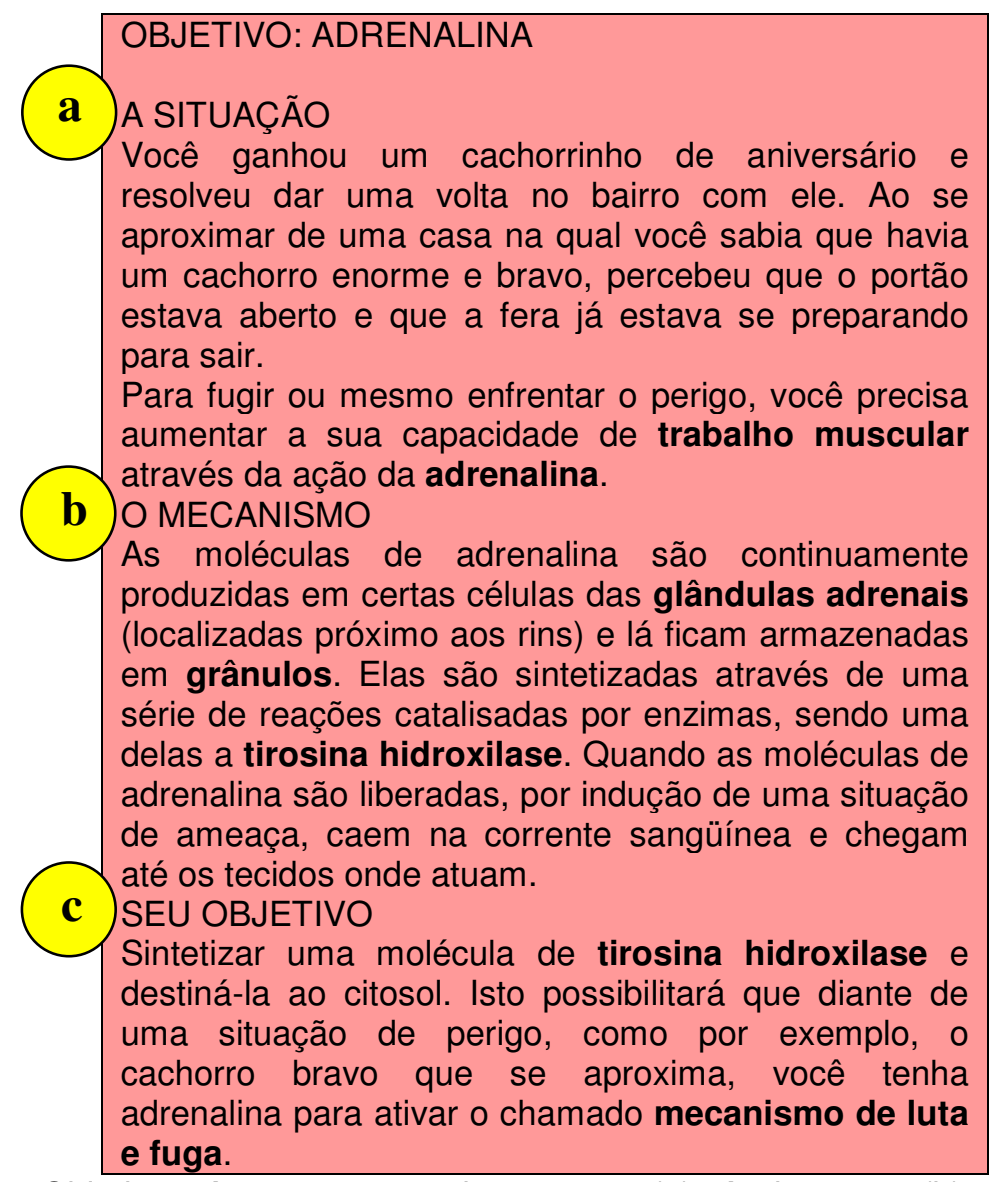

Figura 4 - "Carta-Objetivo". A mesma possui 3 seções: (a) "A situação"; (b) "O mecanismo" e (c) "Seu objetivo". 
Para cada etapa do jogo há peças de tabuleiro, representativas de estruturas bioquímicas específicas (fig. 5). A primeira peça é uma fita quadriculada (com 20 quadrados), representando o "RNA mensageiro", sendo o primeiro quadrado, colorido, destinado à "RNA polimerase" e os demais quadrados à escrita dos nucleotídeos correspondentes. Essa peça participa da $1^{\underline{a}}$ e $2^{\underline{a}}$ etapas (fig. 5a). A segunda peça é uma fita quadriculada (com 5 quadrados), representando a estrutura primária da proteína a ser formada, em que os quadrados destinam-se à escrita dos aminoácidos correspondentes. Essa peça é utilizada na $3^{\underline{a}}$ etapa (fig. $\left.5 b\right)$. A terceira é um círculo colorido representativo da proteína após seu processamento, utilizado na $4^{a}$ e $5^{a}$ etapas, com o desenho de uma proteína em forma de "P" (fig. 5c). Essas peças "caminham" pelo tabuleiro em regiões específicas, representadas pelos mesmos formatos e desenhos no tabuleiro, mostradas na figura 3b.
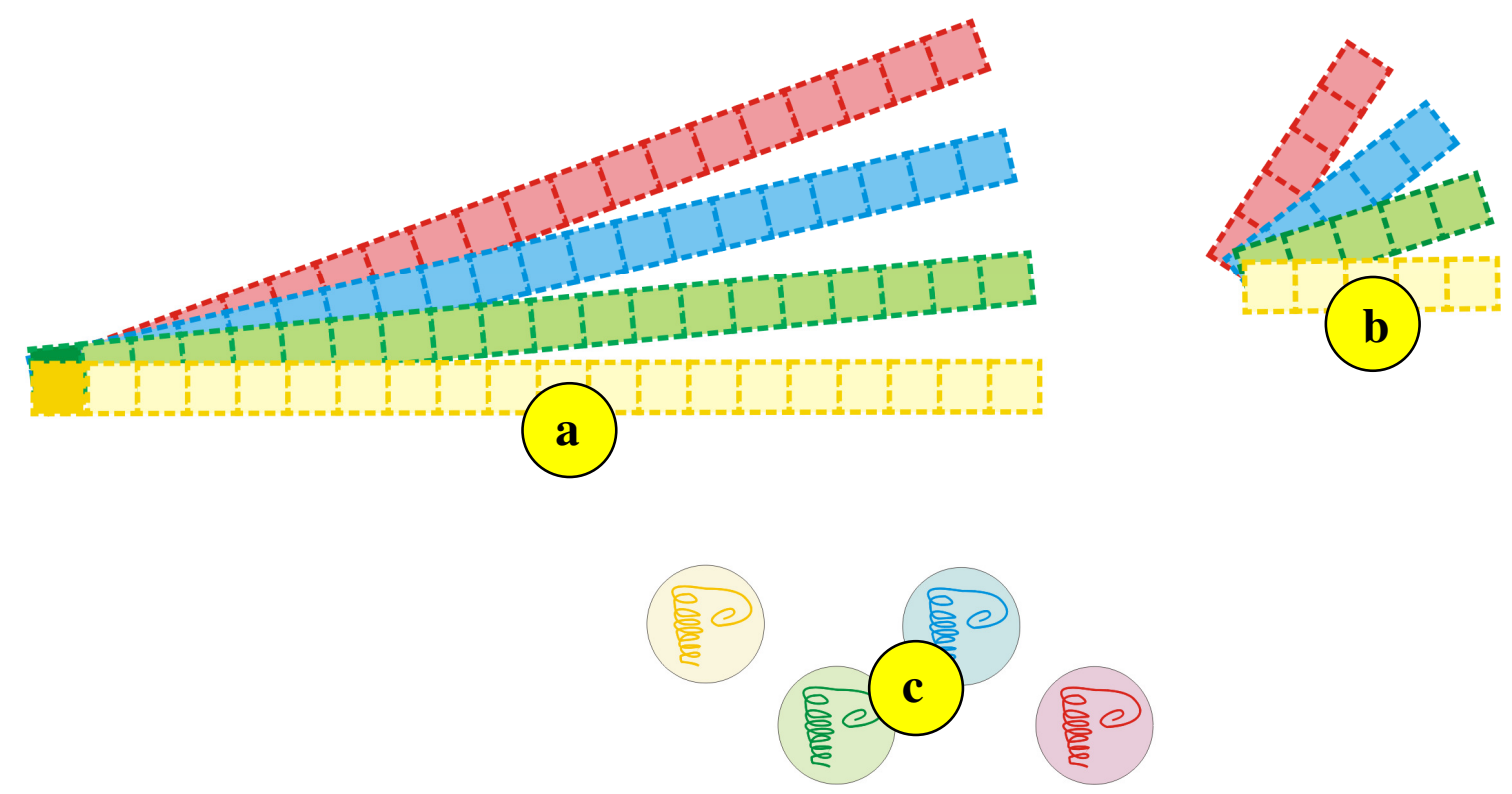

Figura 5 - Peças de tabuleiro representativas de estruturas bioquímicas, apresentada em 4 cores diferentes. (a) RNA mensageiro; (b) Estrutura primária da proteína e (c) Proteína processada.

Por último temos as cartas responsáveis pela dinâmica do jogo, denominadas "cartas-ação" (fig. 6), uma vez que são elas que permitem aos 
participantes avançar pelas etapas, como veremos a seguir. Com o intuito de otimizar o processo, as cartas apresentam duas opções de ação separadas pela conjunção "OU", indicando alternância ou exclusão, de forma que dependendo da etapa que o participante ou grupo estiver, poderá escolher a opção que lhe for conveniente. Apenas duas cartas, "RNAse" e "protease", não oferecem essa opção, e possuem ações paralelas ao processo, podendo destruir parte do que outro participante já construiu (será melhor detalhado no tópico seguinte).
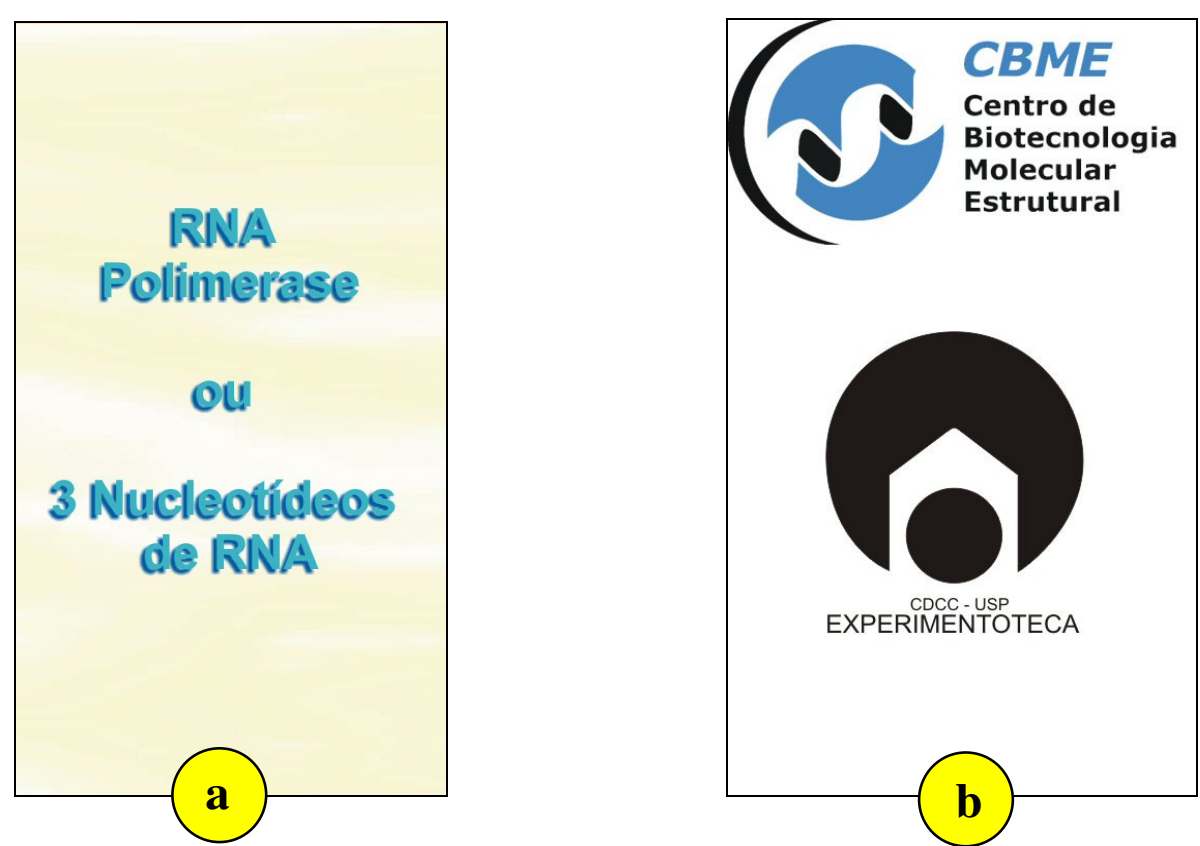

Figura 6 - 'Carta-ação'. (a) A parte interna do cartão, com duas opções de ação, separadas pela conjunção "ou"; (b) Verso do cartão com os logotipos do CBME e do projeto "experimentoteca" do CDCC/USP (Centro de Difusão Científica e Cultural da Universidade de São Paulo. 
A tabela 3.1 mostra os tipos de cartões "requeridos" para cada etapa a ser cumprida por cada participante ou grupo.

Tabela 3.1 - Tipos de cartas necessários para completar cada etapa do jogo.

\begin{tabular}{|c|c|c|}
\hline Etapas & Local de ocorrência & Cartas \\
\hline $\begin{array}{l}1^{\underline{a}} \text { etapa } \\
\text { Transcrição do RNA }\end{array}$ & Núcleo & $\begin{array}{l}\text { RNA polimerase } \\
\mathrm{n}^{\star} \text { nucleotídeos de RNA }\end{array}$ \\
\hline $\begin{array}{l}2^{\underline{a}} \text { etapa } \\
\text { Atravessar a carioteca }\end{array}$ & Citosol & Atravessar a carioteca \\
\hline $\begin{array}{l}3^{\text {a }} \text { etapa } \\
\text { Tradução }\end{array}$ & $\begin{array}{c}\text { Citosol ou Retículo } \\
\text { Endoplasmático Rugoso }\end{array}$ & $\begin{array}{l}\text { Ribossomo } \\
\text { RNAs transportadores + } \\
\mathrm{n}^{*} \text { aminoácidos }\end{array}$ \\
\hline $\begin{array}{l}4^{\underline{a}} \text { etapa } \\
\text { Processamento da proteína }\end{array}$ & $\begin{array}{c}\text { Citosol ou Complexo de } \\
\text { Golgi }\end{array}$ & Processar Proteínas \\
\hline $\begin{array}{l}5^{a} \text { etapa } \\
\text { Endereçamento das proteínas }\end{array}$ & $\begin{array}{c}\text { Membrana plasmática, } \\
\text { meio extra-celular ou } \\
\text { organelas citoplasmáticas }\end{array}$ & Destinar proteína \\
\hline
\end{tabular}

${ }^{*}$ ) corresponde a uma variável numérica, simbolizando que alguns cartões possuem mais de um tipo, dependendo do valor dessa variável.

\subsubsection{Descrição da dinâmica do jogo}

\section{a) Procedimentos preliminares}

O número máximo de participantes (ou grupos) do jogo é 4 e por isso todas as peças e cartas do jogo, com exceção das 'cartas-ação', vêm em 4 cores: vermelho, azul, verde e amarelo.

Cada participante ou grupo deverá escolher uma das cartas-objetivo, de acordo com a cor que assim o desejar e retirar o material correspondente à cor de sua escolha (fita do RNA mensageiro, fita da estrutura primaria da proteína e círculo representativo da proteína processada). Cada participante ou grupo lê em voz alta o 
conteúdo de sua carta-objetivo, a fim dos outros participantes tomarem conhecimento de todas as proteínas a serem formadas, seus mecanismos biológicos e onde atuarão dentro da célula.

\section{b) A primeira rodada}

Um dos participantes embaralha o maço de cartas-ação e em seguida distribui cinco cartas para cada participante, depositando o restante das cartas na região destinada ao maço de compras, com as informações viradas para baixo. 0 mesmo participante que embaralhou e distribuiu dá início ao jogo. De acordo com a seqüência da tabela 3.1, o mesmo verifica se entre as cartas em suas mãos existe uma com a opção "RNA polimerase", que só precisa ser apresentada uma única vez. Em caso negativo, o participante não poderá prosseguir, escolhendo uma das cartas para descartar, depositando-a na região do tabuleiro destinada a este propósito e passando a vez ao participante à sua direita. Em caso positivo o mesmo estará habilitado a prosseguir e havendo cartas com "n nucleotídeos de RNA" poderão fazer associações com outras cartas similares, somando-se as quantidades de nucleotídeos envolvidas, desde que reserve uma das cartas para a efetuação do descarte.

\section{c) Demais rodadas}

As demais rodadas seguem a seguinte seqüência de ações: 1) compra de

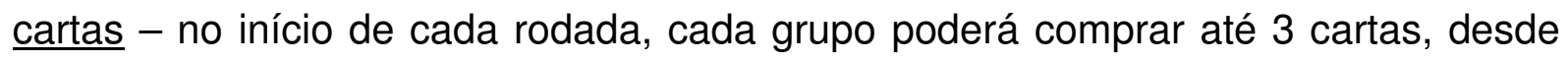
que não ultrapasse 5 em sua mão. Dessa forma, se o participante da vez tiver 1 ou 2 
cartas na mão, poderá comprar 3 , se tiver 3 cartas na mão, só poderá comprar 2 e se tiver com 4 cartas na mão, só poderá comprar apenas uma; 2) Utilização das

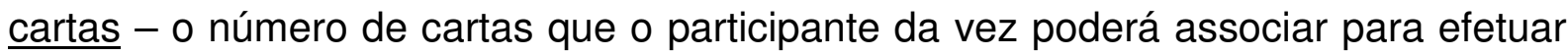
suas ações corresponde ao número de cartas que estiver em sua mão, menos uma. Assim, se o participante possui 5 cartas na mão, só poderá utilizar 4, se tiver 4 , só poderá utilizar 3 e assim por diante, pois uma das cartas deverá ser obrigatoriamente descartada; 3) $\underline{O \text { descarte }}$ - após o participante ter efetuado suas ações, o mesmo deverá escolher uma, dentre as cartas que restaram em sua mão, e descartá-la, depositando-a na região do tabuleiro destinada a esta finalidade.

\section{d) As cartas-coringa}

Dentre as cartas-ação que os participantes poderão associar para completar as etapas até cumprir seus objetivos dentro do jogo ora proposto, destacam-se duas delas que tem o objetivo, ao ser apresentada, não de proporcionar ao participante da vez um avanço nas etapas do processo, mas como um "trunfo" a ser usado contra outros participantes, atrasando-os. Uma delas denomina-se "RNAse", que tem o "poder" de fazer com que o participante escolhido apague metade dos nucleotídeos que já havia sido escrito na fita do RNA mensageiro, na $1^{\text {a }}$ etapa. A outra carta, denominada "Protease", ao ser apresentada a um dos participantes, faz com que o mesmo tenha que apagar metade dos aminoácidos já escritos na fita da estrutura primária da proteína, na $3^{\underline{a}}$ etapa.

Essas cartas só têm "validade" nas etapas indicadas anteriormente, ou seja, a partir do momento que um participante já estiver na $2^{\mathrm{a}}$ etapa, os mesmos estarão "imunes" à ação da RNAse. Da mesma forma, a "protease" só poderá ser 
apresentada a participantes que estiverem na $3^{\underline{a}}$ etapa; uma vez avançados para $4^{\underline{a}}$ etapa estarão “imunes” a sua ação.

\section{e) Finalizando o jogo}

O jogo poderá ser finalizado de duas formas: quando o primeiro dos participantes atingir a $5^{\text {a }}$ e última etapa ou somente quando o último participante 0 fizer.

A partir de um desses eventos, cada participante lê novamente seu objetivo para os demais estudantes, abrindo-se uma sessão de discussão a respeito do que aconteceria com a célula, e conseqüentemente ao organismo, se uma daquelas

proteínas a serem formadas não fosse expressa. Nesse caso, se ressaltaria a importância da proteína na resolução da situação-problema descrita em cada cartaobjetivo. Pode-se também abordar o fato de que os processos de síntese das diferentes proteínas em nosso organismo ocorrem simultaneamente, além disso, a comparação entre as proteínas abordadas no jogo pode levar os alunos a perceberem sua diversidade de funções e importância para o organismo.

\subsection{A avaliação prévia do jogo por professores de Biologia}

Anteriormente à avaliação do jogo com os alunos, nossos principais alvos de investigação, o mesmo foi submetido à avaliação por professores de Biologia do Ensino Médio, participantes de três cursos de extensão oferecidos pela 
Coordenadoria de Educação e Difusão do CBME. Os cursos tiveram como tema central a introdução a temas relacionados à Biologia Molecular e Biotecnologia, sendo que 0 jogo foi uma das ferramentas didáticas utilizadas para 0 desenvolvimento do conteúdo programático dos cursos. No total tivemos a participação de 34 professores de Biologia. Os cursos foram realizados nas cidades de Sertãozinho (SP) e Natal (RN), no ano de 2006, e em Salvador (BA) em 2007. Esses cursos foram oferecidos em parceria com Diretorias Regionais de Ensino, como foi o caso de Sertãozinho, e também com universidades públicas, como foram os casos de Natal (UFRN) e Salvador (UFBA). Estes cursos não foram restritos somente a professores de Biologia ou áreas afins. Contudo, para a avaliação do jogo "Sintetizando Proteínas" consideramos os relatos dos professores de Biologia por acreditarmos que poderiam contribuir mais efetivamente.

A avaliação consistiu na aplicação de um questionário (ver apêndice A) constituído de uma primeira seção contendo um levantamento a respeito da formação dos professores e também informações relevantes com relação a sua práxis. A segunda seção continha 8 questões, sendo 7 de múltipla escolha contemplando aspectos mensuráveis do jogo, como design, jogabilidade, clareza das regras, interação promovida entre os participantes, etc. A oitava questão era aberta e solicitava a opinião dos professores com relação à aplicabilidade do jogo em sala de aula, levando-se em conta aspectos como tempo de execução do mesmo em relação ao tempo disponível pelos professores para aplicá-los, assim como sugestões adicionais.

O questionário foi aplicado e respondido logo após a atividade com o jogo. 


\subsection{A escolha das escolas participantes e contato com os professores}

Selecionamos uma escola pública estadual e uma privada, por acreditarmos que pudesse oferecer dados que permitiriam a comparação entre os dois sistemas de ensino. Sobretudo esses dados ofereceriam condições à análise da influência desses sistemas no processo de ensino-aprendizagem. Dessa forma selecionamos a Escola Estadual Prof. Dr. Álvaro Guião e a Cooperativa Educacional de São Carlos (Educativa).

Primeiramente agendamos uma reunião com os professores de Biologia de cada escola. Nessa ocasião apresentamos o projeto (ver apêndice B) e os convidamos a participar como professores parceiros. Assim, contamos com a colaboração das professoras Ana Claudia Toledo dos Santos Prado e Alessandra Fernandes Rosa, ambas da E.E. Prof. Dr. Álvaro Guião e a professora Adriana do Valle Berganton, da Educativa.

Após o contato com os professores, a formalização com a escola foi feita mediante o encaminhamento de um termo de autorização à direção de cada escola (ver apêndice C), em que destacávamos a parceria firmada com os professores e o mestrando, bem como solicitávamos sua autorização para a utilização das dependências da escola para a realização da pesquisa, detalhando as etapas e ferramentas a serem utilizadas.

A partir de então o procedimento foi discutir com os professores 0 cronograma de aplicação das atividades, definir as turmas com as quais trabalharíamos e iniciar as atividades previstas pelo projeto. Dessa forma 
trabalhamos com 4 turmas, sendo duas da E. E. Prof. Dr. Álvaro Guião $\left(2^{\circ} D\right.$ e $\left.2^{\circ} G\right)$ e duas do Colégio Educativa $\left(2^{\circ} \mathrm{A}\right.$ e $\left.2^{\circ} \mathrm{B}\right)$, num total de 133 alunos, uma média de 33 alunos por turma.

A seguir apresentamos uma breve descrição de cada escola, destacando seu período de fundação, bem como sua importância para a cidade de São Carlos.

\section{A Escola Estadual Prof. Dr. Álvaro Guião}

"No período de 1911 a 1933, a Escola Normal desfrutou de um grande prestígio. Era a referência pedagógica máxima, hegemônica da educação da cidade e da região (...) uma verdadeira faculdade" (NOSELLA; BUFFA,

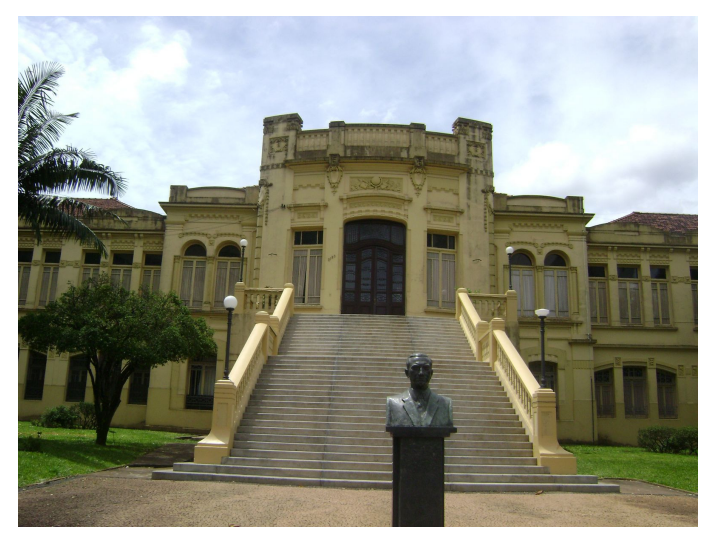

Figura 7 - Vista frontal da escola, com destaque de sua bela escadaria e um busto do Dr. Álvaro Guião. 1996, p. 27). Atendendo às necessidades da elite cafeeira são-carlense da época, Câmara Municipal, políticos e população conseguiram que a Lei Orçamentária de 30/12/1910 destinasse verbas para a instalação da Escola Normal Secundária de São Carlos. Assim, em 3/2/1911 foram feitas as primeiras nomeações do corpo docente e administrativo da escola (NOSELLA; BUFFA, 1996, p. 35). Segundo Nosella e Buffa, a pedra fundamental para a construção do prédio situado entre à avenida São Carlos entre as ruas São Sebastião e Padre Teixeira (Fig. 7) foi lançada em 18/09/1913 e instalada em 1916, cujo acabamento original constava de pisos de cerâmica francesa, lustres de cristal de Baccarat, mármore italiano, mobiliário inglês e austríaco, tamanha sua hegemonia na época. 
Segundo dados da Fundação Pró-memória de São Carlos (FPMSC), em 19 de dezembro de 1939 seu nome foi alterado para Instituto de Educação Dr. Álvaro Guião. Seu nome deve-se a uma homenagem póstuma prestada ao então secretário estadual da Educação e Saúde Pública, Dr. Álvaro de Figueiredo Guião, cargo que exerceu de 7/7/1938 a 14/12/1939, período em que desenvolveu importante atividade administrativa de organização e reorganização dos serviços públicos paulistas nas áreas de educação e saúde. A partir de 1966 passou-se a Escola Estadual prof. Dr. Álvaro Guião.

\section{A Educativa - Instituto de Educação e Cultura}

Idealizada por Oscar Hipólito na década de 1990, a idéia de criação de uma Cooperativa de

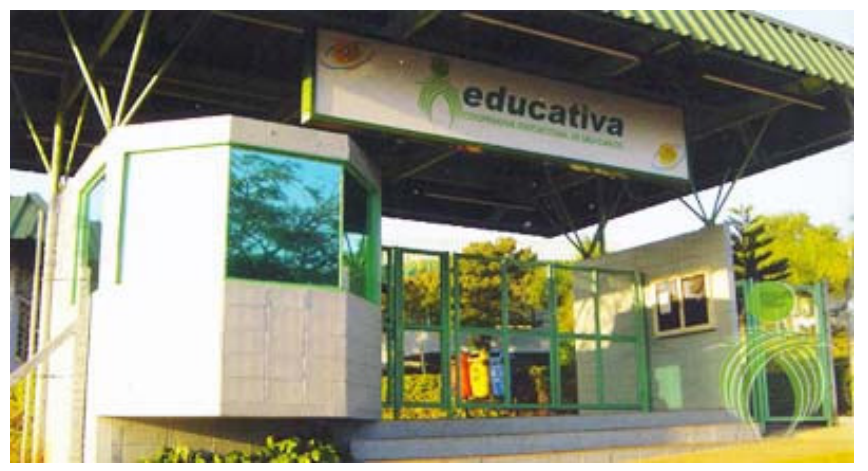

Figura 8 - Vista para a entrada principal da Educativa ensino na cidade de São Carlos

(Fig.8) foi inspirada em modelos já existentes em outras cidades na época, em especial o da cidade de São José do Rio Preto, interior de São Paulo. Teve sua primeira reunião em 9 de março de 1993, com 14 participantes, para a apresentação da proposta e convite para adesão e engajamento ao projeto. Após três reuniões, em uma assembléia marcada para o dia 27 de abril de 1993, já com a presença de 57 pessoas, foi efetivamente criada a "Cooperativa Educacional de São Carlos”, cujo estatuto foi uma adaptação do estatuto da Cooperativa de São José do Rio Preto. A partir de então 'levantaram a bandeira' da Cooperativa entre a população de São Carlos, através de propaganda em folders e outdoors (BRAGA, 1998). 
Em 1 de março de 1994, sob o nome de ‘Educativa - Instituto de Educação e Cultura', teve seu funcionamento autorizado, sendo publicado no Diário Oficial do Estado. O nome 'Educativa', segundo depoimento de Oscar Hipólito à pesquisadora Braga (1998), foi em alusão a uma rádio de Piracicaba que se chamava 'Radio Educativa' e que segundo ele "Educativa tem tudo a ver, é uma educação ativa, é uma coisa ativa, uma coisa dinâmica". O início das aulas deu-se em 7 de março de 1994 com 632 alunos, em sua maioria de classe média, oriundos de escolas particulares de São Carlos, cuja maioria dos pais possuíam nível superior (62\%). Destes, muitos eram pós-graduandos, mestres, doutores e docentes da USP, UFSCar, UNESP e UNICAMP (BRAGA, 1998).

\subsection{A primeira etapa: Levantamento das concepções dos alunos a respeito do tema "proteínas"}

\subsubsection{O questionário diagnóstico: construção e aplicação}

Para essa etapa podemos destacar duas finalidades. A primeira foi a de traçar o perfil dos alunos participantes da pesquisa e a segunda a de levantar as concepções prévias dos alunos com relação ao tema proteínas.

Levando-se em conta nosso público alvo ter sido composto de 133 alunos, optamos pelo uso do questionário. Segundo Gil (2006), uma das vantagens desse instrumento é justamente o fato de possibilitar atingir um grande número de pessoas, além de garantir o anonimato das respostas. 
O questionário diagnóstico (ver apêndice D), assim designado por seu importante papel de fornecer dados norteadores ao restante das etapas da pesquisa, foi uma adaptação de um roteiro de entrevista construído pelo mestrando durante uma disciplina cursada no Departamento de Metodologia de Ensino da Universidade Federal de São Carlos, intitulada 'Pesquisa em metodologia de ensino: Ensino de Ciências e Matemática', com a supervisão da Profa. Dra. Alice Helena Campos Pierson, uma das professoras responsáveis pela disciplina.

Como o tema do trabalho desenvolvido na disciplina descrita acima foi similar ao objetivo dessa etapa do nosso projeto, bastou transformar o roteiro de entrevista em um questionário, adequando seu formato e linguagem ao novo público alvo. O fato de o questionário diagnóstico ter sido oriundo de um roteiro de entrevista outrora aplicado, portanto testado, confere a ele a validação necessária para cumprir com seu propósito.

O questionário diagnóstico (ver apêndice D) é composto por um cabeçalho que descreve sua finalidade e ressalta a importância de se estabelecer laços de confiança e credibilidade entre o pesquisador e os alunos, solicitando aos mesmos autenticidade nas respostas e comprometimento com a pesquisa, além de duas seções denominadas 'Conte um pouco sobre você...' e 'Suas concepções sobre proteínas'.

A seção 'Conte um pouco sobre você...', composta por questões pessoais, sendo algumas de múltipla escolha, teve o objetivo de traçar um perfil dos alunos com respeito ao acesso aos meios de comunicação de massa, quando estudaram e quanto se lembravam do tema proteínas, bem como o grau de escolaridade dos pais. Esses dados foram importantes na caracterização de cada turma em particular e das escolas envolvidas de um modo geral. 
A seção 'Suas concepções sobre proteínas' foi dividida em seis questões abertas. As questões foram dispostas em ordem crescente de complexidade, de forma que a questão 1, mais geral, permitia a investigação da noção dos alunos com respeito ao conceito 'proteína'. A questão 2 buscava a relação entre o conceito de proteína e sua aplicação na classificação de estruturas que eram compostas por proteínas. A questão 3 desafiava os alunos a expor sua opinião a respeito da função das proteínas e com relação às propagandas e reportagens. As questões 4 e 5, mais complexas, buscavam a compreensão dos alunos com relação a dois mecanismos celulares distintos: a síntese e a absorção das proteínas. A sexta questão tinha a função de verificar a correspondência que os alunos faziam do conceito de proteína com algumas doenças.

Após agendamento prévio com os professores parceiros, o mestrando visitou cada turma a fim de aplicar o questionário diagnóstico, quando apresentou de forma sucinta o projeto a ser desenvolvido e a parceria com a escola e o professor parceiro. Ressaltou também a importância da colaboração dos alunos para o êxito desse projeto. Teve boa recepção por parte dos alunos, com demonstração de respeito e prazer em contribuir com a pesquisa.

O procedimento para a aplicação do questionário diagnóstico constou primeiramente da leitura e esclarecimento de cada questão e seus principais objetivos. Mesmo após a leitura, enquanto os alunos respondiam o questionário, o mestrando se colocou a disposição para sanar qualquer dúvida que pudesse impedir os alunos de respondê-lo com clareza.

De uma maneira geral, os alunos tiveram cerca de 1,5 h para responderem ao questionário, o que permitiu que os mesmos o fizessem sem que o tempo fosse um fator limitante. Ao término da aplicação do questionário o mestrando expôs aos 
alunos as próximas etapas do projeto. Com isso solicitou voluntários para participarem da próxima etapa, a pré-entrevista.

\subsubsection{A pré-entrevista: Seleção dos alunos e aplicação}

Antes de descrevermos como se deu a seleção dos alunos e aplicação da entrevista nas escolas, justificaremos o uso dessa técnica e suas vantagens em relação ao questionário.

A escolha pela entrevista após a aplicação do questionário diagnóstico baseou-se em suas características, pois segundo Gil (2006) trata-se de uma técnica eficiente para a obtenção de dados em profundidade. Gil ressalta ainda que em comparação ao uso do questionário, a entrevista possibilita a obtenção de um maior número de respostas, posto que seja mais fácil deixar de responder a alguma questão de um questionário do que diante do entrevistador, durante uma entrevista. Além disso, essa técnica oferece flexibilidade, devido ao fato de o entrevistador poder esclarecer as dúvidas com relação às questões e/ou adaptá-las de acordo com cada entrevistado, e possibilita a captação de suas expressões corporais.

Dessa forma o objetivo da pré-entrevista foi complementar os dados obtidos com o questionário diagnóstico. Entretanto, devido ao volume de dados que se obtém de uma entrevista e o tempo necessário desde sua realização até sua transcrição ser bastante grande, foi preciso selecionar uma amostra de alunos. Essa amostra participaria não somente da entrevista, mas de todas as etapas posteriores, 
que incluíam a atividade com o jogo, a pós-entrevista e o auxílio à aplicação do jogo com os demais alunos da turma.

Desse modo, logo após a aplicação do questionário diagnóstico, apresentamos aos alunos as etapas posteriores do projeto e solicitamos voluntários para a realização das mesmas. O critério para a escolha da amostra baseou-se na quantidade de alunos requerentes para o jogo (de 4 a 8 participantes). Com isso contamos com a participação de 6 alunos da E.E. Dr. Álvaro Guião e 9 alunos da Educativa.

Com base no próprio questionário diagnóstico, utilizado como roteiro e seguindo as instruções de Gil (2006, p. 122) e de Moreira e Silveira (1993, p. 61) quanto ao planejamento e conduta de uma entrevista, os procedimentos adotados para cada entrevista constaram de: a) esclarecimento aos alunos acerca dos objetivos da entrevista e a importância do comprometimento dos mesmos com a veracidade das respostas; b) comunicação a respeito da gravação da entrevista em formato mp3, justificando que sua utilização restringia-se somente à pesquisa e, portanto o nome dos alunos não seria revelado a fim de preservar sua imagem; c) leitura em voz alta de cada questão do questionário diagnóstico respondido pelo aluno com a respectiva resposta e, na seqüência, solicitação de esclarecimento por parte dele, caso a resposta estivesse confusa, ou complementação, caso a resposta ao questionário estivesse incompleta ou muito sucinta; d) um agradecimento ao aluno pela colaboração à pesquisa, feito ao término de cada entrevista. 


\subsection{A segunda etapa: Aplicação do jogo com os alunos da amostra}

Transcorrido cerca de 1 mês após a primeira etapa do trabalho, passamos para a segunda que foi a aplicação do jogo com os alunos da amostra. O objetivo dessa etapa foi o de simular uma situação de sala de aula, em que buscamos testar a compreensão dos alunos não somente com relação às regras do jogo, mas aos conceitos envolvidos e assim traçar relações entre o mesmo e o processo de ensinoaprendizagem dos alunos. Para isso o mestrando se colocou na condição de professor. Nessa ocasião atuou tanto como mediador quanto jogador, participando ativamente com os alunos.

Os procedimentos adotados para a aplicação do jogo constaram de: a) esclarecimento aos alunos acerca dos objetivos dessa etapa e a importância do comprometimento dos mesmos; b) comunicação a respeito da filmagem da aplicação do jogo (gravação de áudio e vídeo), justificando que sua utilização restringia-se somente à pesquisa e, portanto a imagem dos alunos seria preservada; c) distribuição dos materiais do jogo aos alunos ou às duplas (somente os alunos do $2^{\circ} \mathrm{B}$ da Educativa jogaram em duplas, por contarmos com 6 voluntários); d) explicação detalhada das regras do jogo por parte do mestrando; e) início da partida, conduzida pelo mestrando, que atuou como mediador do jogo, esclarecendo as dúvidas dos alunos ao longo de seu desenvolvimento; f) debate, ao término, sobre algumas questões relativas ao jogo, ao processo de síntese protéica e expressão gênica; g) agradecimento aos alunos pela colaboração à pesquisa. 


\subsection{A Terceira etapa: Verificação da aprendizagem e atuação dos tutores em sala de aula}

\subsubsection{A pós-entrevista}

A terceira etapa iniciou-se cerca de 1 mês após o término da segunda. $O$ objetivo dessa etapa foi observar se o jogo de certa forma auxiliou os alunos no entendimento de alguns conceitos, levantados com o questionário diagnóstico e a pré-entrevista. Para tanto a ferramenta utilizada foi novamente a entrevista. Elaboramos então um roteiro composto de 5 questões (ver apêndice E), baseadas em algumas questões do questionário diagnóstico (2c, 3a, 4, 5 e 6 - ver apêndice C), e que tinham uma maior correlação com os conceitos levantados durante a dinâmica do jogo. As questões do roteiro, em relação aos do questionário diagnóstico, apresentam ligeiras modificações, sem alterar sua essência, pois de acordo com Mortimer (2006), quando o que se quer verificar é a ocorrência de algum tipo de evolução conceitual, essa diferenciação entre os instrumentos de ensino usados antes e depois do processo de ensino é bastante válida. Antes do processo de ensino busca-se revelar as concepções dos alunos sobre o assunto e depois detectar e avaliar a presença de conceitos científicos incorporados além de avaliar sua capacidade de generalizar.

O tipo de entrevista adotado foi a semi-estruturada, cujos procedimentos foram os mesmos utilizados na pré-entrevista e já listados na seção 3.4.2. 


\subsubsection{Aplicação do jogo com os demais alunos: A ação dos tutores}

De modo a atender uma solicitação dos professores de ambas as escolas participantes, que gostariam que todos os alunos das 4 turmas utilizassem o jogo, realizamos essa atividade com a colaboração dos 15 alunos da amostra, que atuaram como tutores.

A idéia da participação dos alunos da amostra como tutores surgiu após uma análise prévia dos resultados da avaliação feita pelos professores de Biologia ${ }^{4}$ nos cursos de extensão. A proposição da parceria entre professores e alunos-tutores poderia adequar o desenvolvimento do jogo ao período de uma aula regular.

Decidimos por testar a proposição da parceria entre o professor e alunos tutores. Como havíamos selecionado alguns alunos para a entrevista e aplicação do jogo, os mesmos poderiam se tornar nossos tutores em sala de aula.

O procedimento para a aplicação do jogo com as turmas pode ser resumido nas seguintes etapas: a) divisão da sala de aula em grupos, de acordo com o número de tutores disponíveis; os tutores eram responsáveis em explicar as regras do jogo aos membros do seu grupo e acompanhá-los durante o andamento do mesmo, solucionando as dúvidas que pudessem comprometer o andamento do jogo; b) início do jogo pelos tutores; c) finalização do jogo e início das discussões com cada grupo, com o auxílio do mestrando e o professor da turma; d) aplicação de um questionário a cada tutor (ver apêndice F), em que pedíamos que expressasse sua opinião em relação a sua atuação como tutor, bem como outros comentários que julgasse pertinente.

\footnotetext{
${ }^{4}$ item 8 da questão 3 do questionário aplicado aos professores de Biologia durante os cursos de extensão - ver apêndice A.
} 
Durante a aplicação do jogo pelos tutores, o mestrando ficou livre para circular entre os grupos, levantar questões, iniciar discussões e anotar em seu diário de campo todas as informações relevantes à pesquisa, como as dúvidas mais freqüentes entre os grupos, por exemplo. Além disso, a aplicação foi filmada e dessa forma foi possível registrar o comportamento dos tutores durante a aplicação e assim enriquecer os dados contidos no diário de campo do mestrando.

\subsection{Forma de Análise dos dados}

Após a coleta dos dados, os mesmos foram analisados e interpretados segundo Gil (2006) e Bogdan e Biklen (1994), cujas propostas se baseiam na organização das respostas fornecidas pelos pesquisados em categorias de respostas ou categorias de codificação, respectivamente. Dessa forma, estabelecendo princípios de classificação, os dados puderam ser agrupados em um pequeno número de categorias, facilitando sua interpretação. Esses princípios foram baseados na relação entre a regularidade nos padrões de resposta apresentados pelos alunos frente às possibilidades de resposta impostas por cada questão.

Assim, a análise dos dados oriundos do questionário diagnóstico teve início com o estabelecimento das categorias de resposta para cada questão. Com o auxílio do computador todos esses dados foram codificados e puderam ser tabulados e assim preparados para sua interpretação.

Para as entrevistas (pré e pós) primeiramente foram transcritos os arquivos de áudio e em seguida selecionados os trechos que possibilitavam a comparação 
entre as categorias de respostas encontradas no questionário diagnóstico, em busca de regularidades ou diferenças que fossem relevantes à pesquisa.

Tanto os arquivos de áudio quanto os de vídeo gerados durante a aplicação do jogo com os alunos da amostra foram levados em consideração para a análise. Primeiramente foram transcritos todos os discursos ocorridos durante o jogo e selecionados os trechos cujas interações (aluno-aluno, aluno-mestrando ou alunoobjeto) eram mais ricas e pudessem assim fornecer mais elementos de discussão. Em seguida foram analisados os vídeos dos trechos selecionados, buscando expressões corporais que pudessem complementar as discussões trazidas pelas transcrições.

Para a análise da atuação dos tutores durante a aplicação do jogo com todas as turmas, foram tabulados os dados oriundos do questionário respondidos por eles e as anotações do diário de campo do mestrando enquanto circulava pelos grupos durante a aplicação do jogo. 


\section{CAPÍTULO 4}

RESULTADOS E DISCUSSÃO 



\subsection{A pré-avaliação do jogo com os professores}

Após criarmos o protótipo do jogo e antes de testá-lo com os alunos, decidimos por avaliar sua viabilidade, enquanto uma ferramenta de ensinoaprendizagem, entre professores de Biologia. Para isso o mesmo foi introduzido no contexto de três cursos de extensão oferecidos pelo CBME, cujo tema central foi a introdução de temas relacionados à Biologia Molecular e Biotecnologia, com a participação de 34 professores de Biologia do Ensino Médio, os quais após a manipulação com o jogo responderam a um questionário (ver apêndice A). Após a análise dos questionários, os resultados foram organizados e são apresentados na tabela 4.1.

Em geral, na maioria dos aspectos avaliados, os professores consideraram o jogo 'excelente' ou 'muito bom'. No entanto pudemos perceber que com relação à clareza das regras, 20,6\% consideraram o jogo 'bom' e 11,8\% o consideraram 'regular'. Com relação ao nível das informações apresentadas pelo jogo, 17,6\% consideraram o jogo 'bom'. Quando perguntado se o jogo estimulava a curiosidade, o mesmo foi considerado 'bom' por $14,7 \%$ dos professores. Em resposta à $8^{\text {a }}$ questão, 8,8\% dos professores afirmaram que o jogo não era aplicável em sala de aula devido ao tempo disponível para as aulas de Biologia ser insuficiente, sugerindo que o mesmo fosse aplicado em atividades extraclasse. Metade dos professores alegou ser aplicável desde que levássemos em consideração certos aspectos e/ou sugestões como:

- a explicação das regras deveria ser feita em uma aula, devido à complexidade das regras, e o jogo, trabalhado em outra aula; 
- que o jogo fosse aplicado em aulas duplas e com auxílio de um monitor;

- que o jogo fosse aplicado em atividades extra-classe ou à título de revisão, após o estudo do conteúdo, devido ao tempo de aula ser insuficiente;

- as regras precisariam ser apresentadas de forma mais clara;

- a quantidade de alunos por jogo não poderia ser muito grande.

Tabela 4.1 - pré-avaliação do jogo, realizada por 34 professores de Biologia participantes de cursos de extensão oferecidos pelo Centro de Biotecnologia Molecular Estrutural (CBME/CEPID/FAPESP).

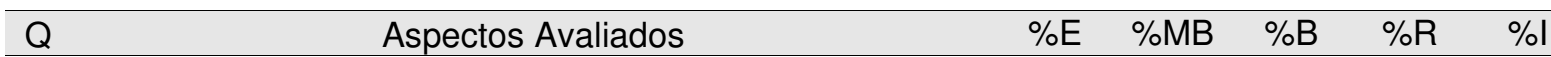

1 Quanto ao design do tabuleiro e materiais

2 Quanto à clareza das regras do jogo

3

Quanto à complexidade e nível das informações abordadas no jogo

4 jogo enquanto um estimulador do raciocínio reflexivo, fazendo contextualizações

O jogo enquanto um estimulador da curiosidade, fazendo-

5 os conhecer onde as proteínas são formadas, como atuam e sua importância para nós

6 O jogo enquanto um facilitador do conhecimento, no caso do processo de síntese de proteínas

7 Quanto ao nível de interação entre os participantes

$67,6 \quad 29,4 \quad 2,9 \quad 0,0 \quad 0,0$

$35,3 \quad 32,4 \quad 20,6 \quad 11,8 \quad 0,0$

$44,1 \quad 38,2 \quad 17,6 \quad 0,0 \quad 0,0$

$64,7 \quad 29,4 \quad 5,9 \quad 0,0 \quad 0,0$

$61,8 \quad 23,5 \quad 14,7 \quad 0,0 \quad 0,0$

$\begin{array}{lllll}61,8 & 35,3 & 2,9 & 0,0 & 0,0\end{array}$

$\begin{array}{lllll}67,6 & 29,4 & 2,9 & 0,0 & 0,0\end{array}$

\%A $\% A R \quad \% N A$

$\mathrm{Na}$ sua opinião, levando-se em conta o tempo médio de

8 duração do jogo e o tempo disponível, o jogo é aplicável em $\quad 41,2 \quad 50,0 \quad 8,8$ sala de aula? Comente e dê sugestões.

\section{\# Não Aplicável (categoria de resposta):}

Os professores alegaram falta de tempo, tanto no que diz respeito ao tempo em sala de aula quanto o número de aulas semanais, sugerindo que o mesmo fosse melhor aplicado em situações extra-classe. 
Continuação

\# Restrições à aplicação (categorias de resposta):

1. Precisa de uma boa mediação por parte do professor, pois as regras são complexas. O melhor seria explicar as regras em uma aula e somente jogar numa próxima aula.

2. O jogo seria muito bem aplicado em aulas práticas (duplas) desde que haja auxílio de um monitor para juntamente com o professor esclarecer as regras do jogo e acompanhar o seu desenvolvimento em cada grupo.

3. O fator tempo é crucial. Mesmo com aulas duplas talvez não seria suficiente, sendo sugerido se trabalhar ao longo de várias aulas, talvez um mês. Talvez seja mais adequado para atividades extraclasse ou quando já tiver terminado o conteúdo, a título de revisão.

4. O jogo poderá ser aplicado em sala de aula desde que a turma seja pequena (o jogo é para 4 participantes). O tempo médio encaixa-se dentro do tempo da aula sendo uma atividade mais atraente para o aluno. A sugestão é somente quanto as regras do jogo que, na minha opinião, precisa ser apresentada de uma forma mais clara.

5. O número de participantes por jogo também é um fator a ser levado em conta. Para isso a escola deverá ter muitos jogos, para que os grupos não fiquem com muitos alunos

Legenda: $\mathbf{E}=$ excelente; $\mathbf{M B}=$ muito bom $; \mathbf{B}=$ bom; $\mathbf{R}=$ regular; $\mathbf{I}=$ insuficiente.

$\mathbf{A}=$ aplicável; $\mathbf{A R}=$ aplicável com ressalvas; $\mathbf{N A}$ = não aplicável.

Esses resultados nos mostram que, na visão desses professores, o jogo apresentou certa complexidade, necessitando assim de uma revisão de certos aspectos antes de sua apresentação aos alunos, para que o mesmo pudesse auxiliar de modo mais efetivo o processo de ensino-aprendizagem deste tópico.

Todos os dados levantados com essa avaliação foram levados em consideração na preparação das atividades a serem aplicadas com os alunos.

Dessa forma, num primeiro momento, optamos por aplicar o jogo apenas com os alunos selecionados para a pré-entrevista para que o mestrando pudesse acompanhar mais de perto a execução do jogo, explicar claramente as regras, verificar as dificuldades encontradas pelos alunos, tanto com relação às regras quanto com relação ao conteúdo, além de testar o tempo necessário para a sua execução. Num segundo momento optamos por aplicar o jogo em sala de aula. Para isso decidimos testar as potencialidades e limitações da proposição de alunos tutores para auxiliar o professor na condução das atividades. Nessa ocasião, os 
alunos selecionados para o primeiro momento foram convidados a participarem do segundo momento, em que cada um conduziria um grupo dentro da sala de aula. Para cada turma utilizamos 5 conjuntos de jogos, de forma que cada conjunto comportava 4 duplas de alunos, de forma que o número de alunos não fosse um fator limitante.

Nas próximas seções apresentaremos os resultados referentes à avaliação do jogo com os alunos, em termos de suas potencialidades e limitações no processo de ensino e aprendizagem dos conceitos envolvidos - 'proteína' e 'síntese protéica' -, bem como da atuação dos alunos tutores em sala de aula.

\subsection{A avaliação do jogo com os alunos}

\subsubsection{O perfil dos alunos}

A primeira sessão do questionário diagnóstico, "conte um pouco sobre você", composta de 13 questões, objetivou o levantamento de algumas informações de caráter geral e que poderiam ser relevantes à pesquisa, de forma a permitir a caracterização das turmas envolvidas, a fim de conhecermos os alunos antes de direcionarmos as atividades. A tabela 4.2 apresenta as respostas a essas perguntas, exceto as dadas às questões 1 a 6 , que correspondiam aos dados pessoais dos alunos.

Com relação à questão 7 (tab. 4.2), que contemplava em que momento os alunos haviam estudado o tema 'proteína', podemos perceber que para $38,5 \%$ dos 
alunos do Álvaro Guião esse conteúdo foi estudado há muito tempo e somente $26,2 \%$ afirmaram terem estudado no ano anterior, enquanto para $92,6 \%$ dos alunos da Educativa tinha sido no ano anterior. Em virtude disso, 64,5\% dos alunos do Álvaro Guião afirmaram se lembrar pouco do assunto e em torno de $17 \%$ não se lembravam de nada, enquanto os alunos da Educativa se dividiram entre os que se lembravam médio $(42,6 \%)$ e pouco $(41,2 \%)$. Neste caso, é importante ressaltarmos que para a Escola Educativa havia apenas uma professora responsável pelas aulas de Biologia do Ensino Médio, além do número reduzido de turmas e a maioria dos alunos começarem e completarem seus estudos nessa escola. Tal regularidade foi observado para a escola Álvaro Guião, enquanto uma escola pública.

Tabela 4.2 - Dados referentes ao levantamento do perfil dos alunos (65 alunos do Álvaro Guião e 68 alunos da Educativa), obtidos a partir das respostas à "conte um pouco sobre você", do questionário diagnóstico, em termos de porcentagem (\%).

\begin{tabular}{|c|c|c|c|c|c|}
\hline \multicolumn{3}{|c|}{$\begin{array}{l}\text { 7. Quando foi a última vez que estudou } \\
\text { sobre proteínas? }\end{array}$} & \multicolumn{3}{|c|}{ 8. Quanto se lembra? } \\
\hline & Alvaro Guião & Educativa & & Alvaro Guião & Educativa \\
\hline Ano Passado & 26,2 & 92,6 & Muito & 0,0 & 2,9 \\
\hline Este ano & 0,0 & 0,0 & Médio & 15,4 & 42,6 \\
\hline Não Lembro & 13,8 & 2,9 & Pouco & 64,6 & 41,2 \\
\hline Muito Tempo & 38,5 & 0,0 & Nada & 16,9 & 8,8 \\
\hline Nunca & 6,2 & 0,0 & Não respondeu & 3,1 & 4,4 \\
\hline $\begin{array}{c}\text { Não } \\
\text { respondeu }\end{array}$ & 15,4 & 4,4 & Total & 100,0 & 100,0 \\
\hline Total & 100,0 & 100,0 & & & \\
\hline
\end{tabular}

\begin{tabular}{ccc}
\hline a. acesso & & \\
\hline & Alvaro Guião & Educativa \\
\cline { 2 - 3 } Sim & 12,3 & $\mathbf{5 7 , 4}$ \\
Não & $\mathbf{8 4 , 6}$ & 41,2 \\
Não & & 1,5 \\
Respondeu & 3,1 & 100,0 \\
\hline Total & 100,0 & \\
\hline
\end{tabular}

\section{c. tipos de revistas}

SCIAM

GALILEU

\begin{tabular}{cc} 
Alvaro Guião & Educativa \\
\hline 0,0 & 7,4 \\
3,1 & 0,0
\end{tabular}

$\mathrm{CH}$

SUPER

0,0

1,5

OUTRAS

4,6

19,1

Não respondeu

40,0

7,4

41,2

\begin{tabular}{ccc}
\hline \multicolumn{3}{l}{ b. tipo de acesso } \\
\hline & Alvaro Guião & Educativa \\
\cline { 2 - 3 } Escola & 12,3 & 17,6 \\
\hline
\end{tabular}

d. com que freqüência?

\begin{tabular}{ccc} 
& Alvaro Guião & Educativa \\
\cline { 2 - 3 } Diariamente & 0,0 & 2,9 \\
\hline & & Continua
\end{tabular}




\begin{tabular}{ccc}
\hline \multicolumn{3}{l}{ b. tipo de acesso } \\
\hline & Alvaro Guião & Educativa \\
\cline { 2 - 3 } Internet & $\mathbf{2 3 , 1}$ & $\mathbf{3 2 , 4}$ \\
Assinante & 9,2 & 25,0 \\
Não & & \\
Respondeu & 6,2 & 13,2 \\
\hline
\end{tabular}

\begin{tabular}{lcc} 
& & Continuação \\
\hline d. com que freqüência? & \\
\cline { 2 - 3 } Semanalmente & 10,8 & Educativa \\
\cline { 2 - 3 } Mensalmente & 3,1 & $\mathbf{2 0 , 6}$ \\
& $\mathbf{2 0 , 6}$ \\
Dificilmente & $\mathbf{2 6 , 2}$ & 19,1 \\
Não respondeu & 4,6 & 7,4 \\
\hline
\end{tabular}

10. Tem acesso ou se interessa por programas de televisão, seja em canais abertos seja em TV por assinatura, que discutem sobre ciência?

\begin{tabular}{ccc}
\hline a. acesso & & \\
\hline & Alvaro Guião & Educativa \\
\cline { 2 - 3 } Sim & $\mathbf{5 2 , 3}$ & $\mathbf{6 6 , 2}$ \\
Não & 44,6 & 30,9 \\
Não respondeu & 3,1 & 2,9 \\
Total & 100,0 & 100,0 \\
\hline
\end{tabular}

\section{Assuntos pelos quais se interessa}

\begin{tabular}{ccc}
\hline b. Canais & & \\
\hline & Alvaro Guião & Educativa \\
\cline { 2 - 3 } GLOBO & $\mathbf{2 1 , 5}$ & 1,5 \\
CULTURA & $\mathbf{1 3 , 8}$ & 2,9 \\
NATGEO & 4,6 & $\mathbf{2 5 , 0}$ \\
DISCOVERY & 7,7 & $\mathbf{5 0 , 0}$ \\
FUTURA & 7,7 & 1,5 \\
ANIMALP. & 0,0 & 2,9 \\
OUTROS & 1,5 & 2,9 \\
Não respondeu & 10,8 & 13,2 \\
\hline
\end{tabular}

\begin{tabular}{ccc} 
& Alvaro Guião & Educativa \\
\cline { 2 - 3 } Física & 23,1 & 20,6 \\
Cosmologia & 9,2 & 20,6 \\
Astronomia & 26,2 & 23,5 \\
Tecnologia & $\mathbf{3 8 , 5}$ & $\mathbf{5 8 , 8}$ \\
Biologia & 27,7 & $\mathbf{5 8 , 8}$ \\
Biotecnologia & 6,2 & 36,8 \\
Ecologia & 26,2 & $\mathbf{5 2 , 9}$ \\
História & $\mathbf{3 8 , 5}$ & 27,9 \\
Arqueologia & 21,5 & 17,6 \\
Neurociência & 3,1 & 25,0 \\
\hline
\end{tabular}

\section{Grau de escolaridade dos pais}

\begin{tabular}{ccccccc}
\cline { 5 - 6 } & \multicolumn{2}{c}{ Álvaro Guião } & & \multicolumn{2}{c}{ Educativa } \\
\cline { 2 - 3 } \cline { 5 - 6 } & Pai & Mãe & & Pai & Mãe \\
\hline F. Incompleto & 13,8 & $\mathbf{2 9 , 2}$ & & 0,0 & 0,0 \\
F. Completo & 9,2 & 6,2 & & 0,0 & 0,0 \\
M. Incompleto & 15,4 & 13,8 & & 0,0 & 4,4 \\
M. Completo & $\mathbf{4 0 , 0}$ & $\mathbf{2 6 , 2}$ & & 5,9 & 4,4 \\
S. Incompleto & 3,1 & 4,6 & & 2,9 & 10,3 \\
S. Completo & 7,7 & 10,8 & & 35,3 & 38,2 \\
Pós-graduação & 6,2 & 6,2 & & $\mathbf{5 5 , 9}$ & $\mathbf{4 1 , 2}$ \\
Não Respondeu & 4,6 & 3,1 & & 0,0 & 1,5 \\
\hline Total & 100,0 & 100,0 & & 100,0 & 100,0 \\
\hline
\end{tabular}

As questões 9 e 10 contemplavam o acesso dos alunos com relação aos meios de comunicação de massa, como revistas e TV. Era esperado que os alunos 
da escola Educativa, por pertencerem as classes média e alta e a escola dispor de infra-estrutura como sala de informática com acesso a internet, por exemplo, apresentassem resultados que comprovassem maior acesso a revistas de divulgação científica e a canais por assinatura. Essa diferença é contemplada também com relação ao grau de escolaridade dos pais, em que para a maioria dos alunos do Álvaro Guião os pais possuem até o ensino médio completos, ao passo que para os alunos da Educativa a maioria possui pós-graduação.

Um dado bastante curioso foi com relação aos assuntos pelos quais os alunos mais se interessam. Tecnologia e Biologia estão entre os mais interessantes entre $58,8 \%$ dos alunos da Educativa, enquanto para os alunos do Álvaro Guião apenas $38,5 \%$ e $27,7 \%$ respectivamente. $36,8 \%$ dos alunos da Educativa acham Biotecnologia um assunto interessante contra 6,2\% dos alunos do Álvaro Guião.

Esse levantamento também teve outra função complementar que era a de fornecer elementos que pudessem enriquecer as discussões ao comparar as duas escolas envolvidas no que diz respeito ao nível social dos alunos e a influência do sistema de ensino no desempenho dos alunos, discutidas nas próximas seções.

\subsubsection{As concepções dos alunos com respeito à 'proteínas'}

A segunda parte do questionário diagnóstico (ver Apêndice D) teve por objetivo, o levantamento das concepções apresentadas pelos alunos a respeito das proteínas. As questões foram elaboradas de forma a contemplar desde a definição de uma proteína, até processos como síntese e metabolismo das mesmas. Os 
dados foram analisados e interpretados baseados em Gil (2006) e em Bogdan e Biklen (1994), cuja proposta se baseia na organização das respostas fornecidas pelos pesquisados em categorias de respostas ou categorias de codificação, respectivamente. Os resultados encontram-se dispostos na tabela 4.3, organizada de forma a expressar a freqüência das categorias de resposta citadas, separadas por escola, em termos de número de alunos e porcentagem (em relação ao total de cada escola), bem como a somatória de citações para cada categoria, com sua respectiva porcentagem em relação ao universo de alunos estudados. Participaram dessa etapa 133 alunos, sendo 65 oriundos da Escola Estadual Dr. Álvaro Guião (30 alunos do $2^{\circ} \mathrm{G}$ e 35 do $2^{\circ} \mathrm{D}$ ) e 68 alunos da Educativa (33 alunos do $2^{\circ} \mathrm{A}$ e 35 do 2으).

Tabela 4.3 - Dados referentes ao levantamento das concepções dos alunos a respeito do tema 'proteínas', através da aplicação do questionário diagnóstico. Os dados foram organizados de forma a contemplar as categorias de reposta apresentadas pelos alunos a cada questão, bem como a freqüência com que cada categoria foi encontrada na análise dos questionários de cada turma envolvida no projeto. $O$ público constou de 133 alunos (2DAG - 30; 2ํGAG - 35; 2ํAEDU - 33 e 2BEDU - 35).

Q. 1a - Qual sua opinião a respeito da afirmação do zulu - "Macarrão é proteína"... Comente

\section{Categorias de respostas}

1. Consideram a afirmação errada, justificando que macarrão é carboidrato.

2. Manifestam dúvida ou discordam parcialmente da afirmação, predominando respostas que afirmam que macarrão contém alguma proteína.

3. Macarrão é outra macromolécula que não carboidrato

4. Consideram a afirmação correta, concordando que macarrão seja proteína

Não souberam ou não responderam

\section{sua resposta}

Álvaro Guião $\quad$ Educativa $\quad$ Total

$12(18,5 \%)$

$53(77,9 \%)$

$65(48,9 \%)$

$28 \quad(43,1 \%)$

$7 \quad(10,3 \%)$

$35 \quad(26,3 \%)$

\author{
$5 \quad(7,7 \%)$
}

$6 \quad(8,8 \%)$

$11(8,3 \%)$

$6(9,2 \%)$

2 (2,9\%)

$8(6,0 \%)$

$14 \quad(21,5 \%)$

$0 \quad(0,0 \%)$

$14 \quad 10,5 \%$

$65(100,0 \%)$

$68 \quad(100,0 \%)$

$133 \quad 100,0 \%$


Continuação

Q. 1b - Falando em proteínas, o que você entende por PROTEÍNA?

Categorias de respostas Álvaro Guião

Educativa

Total

1. Respostas Genéricas que relacionam proteína ao bemestar próprio, fornecendo energia, força... Ao próprio $42(64,6 \%)$

$31(45,6 \%)$

$73(54,9 \%)$ organismo

2. Caracteriza estruturalmente a proteína (cadeia polipeptídica, formada por aminoácidos...)

\begin{tabular}{rlrlrl}
3 & $(4,6 \%)$ & 26 & $(38,2 \%)$ & 29 & $(21,8 \%)$ \\
0 & $(0,0 \%)$ & 5 & $(7,4 \%)$ & 5 & $(3,8 \%)$ \\
20 & $(30,8 \%)$ & 6 & $(8,8 \%)$ & 26 & $(19,5 \%)$ \\
\hline 65 & $(100,0 \%)$ & 68 & $(100,0 \%)$ & 133 & $(100,0 \%)$ \\
\hline
\end{tabular}

3. Remete as funções das proteínas

Não souberam ou não responderam

\section{Total}

\begin{tabular}{rlrl}
\multicolumn{2}{c}{ Educativa } & \multicolumn{2}{c}{ Total } \\
\hline 61 & $(89,7 \%)$ & 99 & $(74,4 \%)$ \\
37 & $(54,4 \%)$ & 77 & $(57,9 \%)$ \\
40 & $(58,8 \%)$ & 56 & $(42,1 \%)$ \\
14 & $(20,6 \%)$ & 38 & $(28,6 \%)$ \\
16 & $(23,5 \%)$ & 28 & $(21,1 \%)$ \\
7 & $(10,3 \%)$ & 27 & $(20,3 \%)$ \\
3 & $(4,4 \%)$ & 26 & $(19,5 \%)$ \\
10 & $(14,7 \%)$ & 24 & $(18,0 \%)$ \\
6 & $(8,8 \%)$ & 23 & $(17,3 \%)$ \\
4 & $(5,9 \%)$ & 17 & $(12,8 \%)$ \\
8 & $(11,8 \%)$ & 12 & $(9,0 \%)$ \\
2 & $(2,9 \%)$ & 8 & $(6,0 \%)$ \\
3 & $(4,4 \%)$ & 5 & $(3,8 \%)$ \\
0 & $(0,0 \%)$ & 3 & $(2,3 \%)$
\end{tabular}

Q. 2b - Essa lista de alimentos ricos em proteínas também incluem vegetais, como verduras e

\begin{tabular}{crlrlrl} 
& \multicolumn{2}{c}{ legumes? } & \multicolumn{2}{c}{ Educativa } & \multicolumn{2}{c}{ Total } \\
\hline Categorias de respostas & \multicolumn{2}{c}{ Álvaro Guião } & 36 & $(52,9 \%)$ & 89 & $(66,9 \%)$ \\
Sim & 53 & $(81,5 \%)$ & 31 & $(45,6 \%)$ & 37 & $(27,8 \%)$ \\
Não & 6 & $(9,2 \%)$ & 1 & $(1,5 \%)$ & 7 & $(5,3 \%)$ \\
Não souberam ou não & 6 & $(9,2 \%)$ & 68 & $(100,0 \%)$ & 133 & $(100,0 \%)$ \\
responderam & 65 & $100,0 \%$ & &
\end{tabular}

\begin{tabular}{|c|c|c|c|c|c|c|}
\hline \multicolumn{7}{|c|}{$\begin{array}{c}\text { Q. 2c - Onde mais podemos encontrar proteínas? Relacione algumas estruturas que } \\
\text { constituem seu corpo ou de outros organismos, como algum tipo de tecido ou secreção, que } \\
\text { seja constituído basicamente por proteínas. }\end{array}$} \\
\hline \multirow{2}{*}{$\begin{array}{c}\text { Categorias de respostas } \\
\text { Cabelo }\end{array}$} & \multicolumn{2}{|c|}{ Álvaro Guião } & \multicolumn{2}{|c|}{ Educativa } & \multicolumn{2}{|c|}{ Total } \\
\hline & 16 & $(24,6 \%)$ & 13 & $(19,1 \%)$ & 29 & $(21,8 \%)$ \\
\hline Músculos & 4 & $(6,2 \%)$ & 18 & $(26.5 \%)$ & 22 & $(16.5 \%)$ \\
\hline $\begin{array}{l}\text { Pele } \\
\text { Pel }\end{array}$ & 16 & $(24.6 \%)$ & 5 & $(7.4 \%)$ & 21 & $(15,8 \%)$ \\
\hline Unha & 10 & $(15,4 \%)$ & 5 & $(7,4 \%)$ & 15 & $(11,3 \%)$ \\
\hline Nas Células (geral) & 8 & $(12,3 \%)$ & 5 & $(7,4 \%)$ & 13 & $(9,8 \%)$ \\
\hline Ossos & 7 & $(10,8 \%)$ & 5 & $(7,4 \%)$ & 12 & $(9,0 \%)$ \\
\hline Suor & 4 & $(6,2 \%)$ & 5 & $(7,4 \%)$ & 9 & $(6,8 \%)$ \\
\hline Órgãos & 4 & $(6,2 \%)$ & 4 & $(5,9 \%)$ & 8 & $(6,0 \%)$ \\
\hline Outros & 1 & $(1,5 \%)$ & 7 & $(10,3 \%)$ & 8 & $(6,0 \%)$ \\
\hline Hormônios & 1 & $(1,5 \%)$ & 0 & $(0,0 \%)$ & 1 & $(0,8 \%)$ \\
\hline $\begin{array}{l}\text { Não souberam ou não } \\
\text { responderam }\end{array}$ & 31 & $(47,7 \%)$ & 14 & $(20,6 \%)$ & 45 & $(33,8 \%)$ \\
\hline
\end{tabular}


Continuação

Q. 3a - A grande questão é: Por quê precisamos tanto de proteínas? Qual é o grande papel que elas exercem nos organismos?

\section{Categorias de respostas}

1. Remetem novamente ao

caráter mantenedor do organismo, dando energia, fortalecendo...

2. Constroem o corpo

3. Oferecem proteção ao organismo

4. Remetem a conteúdos escolares, como funções estruturais, defesa, hormonais....

5. responsáveis pelas características genéticas

6. Quebram moléculas

7. Transportam substâncias no organismo

Não souberam ou não

responderam Álvaro Guião Educativa Total

\begin{tabular}{rlrlrl}
40 & $(61,5 \%)$ & 34 & $(50,0 \%)$ & 74 & $(55,6 \%)$ \\
5 & $(7,7 \%)$ & 8 & $(11,8 \%)$ & 13 & $(9,8 \%)$ \\
7 & $(10,8 \%)$ & 1 & $(1,5 \%)$ & 8 & $(6,0 \%)$ \\
0 & $(0,0 \%)$ & 6 & $(8,8 \%)$ & 6 & $(4,5 \%)$ \\
0 & $(0,0 \%)$ & 5 & $(7,4 \%)$ & 5 & $(3,8 \%)$ \\
0 & $(0,0 \%)$ & 3 & $(4,4 \%)$ & 3 & $(2,3 \%)$ \\
1 & $(1,5 \%)$ & 1 & $(1,5 \%)$ & 2 & $(1,5 \%)$ \\
12 & $(18,5 \%)$ & 10 & $(14,7 \%)$ & 22 & $(16,5 \%)$ \\
65 & $(100,0 \%)$ & 68 & $(100,0 \%)$ & 133 & $(100,0 \%)$ \\
\hline
\end{tabular}

Q. 4 - Não resta dúvida que nosso organismo precisa constantemente suprir suas necessidades de proteínas. Mas como você acha que essas proteínas serão absorvidas pelo nosso organismo? Leve em consideração que os alimentos antes de serem absorvidos passam pelo processo de digestão Categorias de respostas

1. Consideram a quebra das proteínas, antes de serem absorvidas. Álvaro Guião Educativa Total

$$
11(16,9 \%)
$$

$38(55,9 \%)$

$49(36,8 \%)$

2. Apenas descrevem como seria a absorção, sem mencionar quebra, $15(23,1 \%)$ $5 \quad(7,4 \%)$ $20 \quad(15,0 \%)$ considerando a absorção da proteína inteira

3. Respostas confusas que não se enquadram nas categorias acima.

Não souberam ou não responderam

\begin{tabular}{rlrlrl}
1 & $(1,5 \%)$ & 8 & $(11,8 \%)$ & 9 & $(6,8 \%)$ \\
38 & $(58,5 \%)$ & 17 & $(25,0 \%)$ & 55 & $(41,4 \%)$ \\
65 & $(100,0 \%)$ & 68 & $(100,0 \%)$ & 133 & $(100,0 \%)$ \\
\hline
\end{tabular}

\begin{tabular}{|c|c|c|c|c|c|c|}
\hline \multicolumn{7}{|c|}{$\begin{array}{l}\text { Q. } 6 \text { - Você saberia relacionar algumas doenças ou deficiências de que já tenha ouvido falar } \\
\text { em que sua causa está relacionada a alguma proteína específica? Não precisa escrever a } \\
\text { proteína, somente as doencas. }\end{array}$} \\
\hline Categorias de respostas & Álvaro & Guião & Edu & ativa & & \\
\hline 1. Anemia & 10 & $(15,4 \%)$ & 36 & $(52,9 \%)$ & 46 & $(34,6 \%)$ \\
\hline 2. Osteoporose & 3 & $(4,6 \%)$ & 15 & $(22,1 \%)$ & 18 & $(13,5 \%)$ \\
\hline 3. Diabete & 0 & $(0,0 \%)$ & 15 & $(22,1 \%)$ & 15 & $(11,3 \%)$ \\
\hline 4. Albinismo & 0 & $(0,0 \%)$ & 14 & $(20,6 \%)$ & 14 & $(10,5 \%)$ \\
\hline $\begin{array}{l}\text { 5. Mal estar (cansaço, } \\
\text { sonolência, indisposição, } \\
\text { preguiça, câimbra) }\end{array}$ & 2 & $(3,1 \%)$ & 7 & $(10,3 \%)$ & 9 & $(6,8 \%)$ \\
\hline 6. Cegueira noturna & 0 & $(0,0 \%)$ & 9 & $(13,2 \%)$ & 9 & $(6,8 \%)$ \\
\hline 7. Raquitismo & 1 & $(1,5 \%)$ & 6 & $(8,8 \%)$ & 7 & $(5,3 \%)$ \\
\hline 8. Mal Parkinson & 0 & $(0,0 \%)$ & 6 & $(8,8 \%)$ & 6 & $(4,5 \%)$ \\
\hline 9. Prisão de ventre & 0 & $(0,0 \%)$ & 6 & $(8,8 \%)$ & 6 & $(4,5 \%)$ \\
\hline 10. Hipoglicemia & 0 & $(0,0 \%)$ & 4 & $(5,9 \%)$ & 4 & $(3,0 \%)$ \\
\hline
\end{tabular}


Conclusão

Q. 6 - Você saberia relacionar algumas doenças ou deficiências de que já tenha ouvido falar em que sua causa está relacionada a alguma proteína específica? Não precisa escrever a

\begin{tabular}{lccrcrc}
\multicolumn{7}{c}{ proteína, somente as doenças. } \\
\hline 11. Síndrome de Down & 0 & $(0,0 \%)$ & 3 & $(4,4 \%)$ & 3 & $(2,3 \%)$ \\
12. Dores Ósseas & 0 & $(0,0 \%)$ & 3 & $(4,4 \%)$ & 3 & $(2,3 \%)$ \\
13. Doenças da pele & 0 & $(0,0 \%)$ & 3 & $(4,4 \%)$ & 3 & $(2,3 \%)$ \\
14. Fenilcetonúria & 0 & $(0,0 \%)$ & 3 & $(4,4 \%)$ & 3 & $(2,3 \%)$ \\
15. Hanseníase & 0 & $(0,0 \%)$ & 3 & $(4,4 \%)$ & 3 & $(2,3 \%)$ \\
16. Alergia (leite) & 0 & $(0,0 \%)$ & 3 & $(4,4 \%)$ & 3 & $(2,3 \%)$ \\
17. Atrofiamento muscular & 1 & $(1,5 \%)$ & 0 & $(0,0 \%)$ & 1 & $(0,8 \%)$ \\
18. Leucemia & 1 & $(1,5 \%)$ & 0 & $(0,0 \%)$ & 1 & $(0,8 \%)$ \\
19. Bulimia & 1 & $(1,5 \%)$ & 0 & $(0,0 \%)$ & 1 & $(0,8 \%)$ \\
20. Desnutrição & 1 & $(1,5 \%)$ & 0 & $(0,0 \%)$ & 1 & $(0,8 \%)$ \\
21. Gripe & 1 & $(1,5 \%)$ & 0 & $(0,0 \%)$ & 1 & $(0,8 \%)$ \\
22. Virose & 1 & $(1,5 \%)$ & 0 & $(0,0 \%)$ & 1 & $(0,8 \%)$ \\
Não souberam ou não & 48 & $(73,8 \%)$ & 18 & $(26,5 \%)$ & 66 & $(49,6 \%)$ \\
responderam & & & & & &
\end{tabular}

A análise por categoria de resposta nos revela as concepções dos alunos em termos de tendências do pensar.

Com relação à questão $1 \mathrm{a}$, em que foi solicitado aos alunos comentar a afirmação "macarrão é proteína", cujo objetivo era instigar os alunos com respeito ao conceito que tinham sobre proteína e conseqüentemente sobre carboidratos, 65 alunos $(48,9 \%)$ responderam que se tratava de uma afirmação falsa, pois macarrão é composto basicamente por carboidratos. No entanto, destes 65 alunos, 53 eram da Educativa, com respostas do tipo "macarrão contém carboidratos ótimos para fornecer energia, mas não tem nada a ver com proteína", "macarrão não é proteína e sim carboidrato" ou "o comentário foi totalmente errado, macarrão não é fonte de proteínas e sim carboidratos". A maioria dos alunos do Álvaro Guião (28 alunos 43,1\%) apresentou dúvida ou concordou parcialmente com a afirmação, alegando que "no macarrão há muitas proteínas. Nele há trigo e outros componentes", "macarrão é carboidrato, deve ter pouca proteína", "macarrão deve 'conter proteína'... será? Carboidrato, não sei..." ou "não confirmo que é proteína, mas não descarto a hipótese de conter proteína". 
Quando pedido para definirem uma proteína (Q. 1b), $42(64,6 \%)$ alunos do Álvaro Guião e 31 (45,6\%) da Educativa, apresentaram respostas genéricas do tipo "é uma substância essencial ao nosso corpo, indispensável para o desenvolvimento do corpo e sua nutrição", "acho que serve para dar energia, essas coisas...", "proteína é uma substância necessária para o bom funcionamento do organismo, além de ter várias outras funções", indicando uma tendência Em definir genericamente o papel das proteínas no organismo (humano). Esta tendência, de certo modo, foi confirmada pelas respostas dadas à questão $3 a$, quando 55,6\% dos alunos relacionaram proteínas ao caráter mantenedor do organismo, como observado nos trechos: "não se consegue viver bem sem a função que ela exerce no organismo", "porque sem elas nosso corpo não constitui energias para manter nosso corpo saudável", "precisamos de proteínas para que nosso organismo funcione melhor" ou "porque através delas nos mantemos vivos".

Ainda na questão 1b, observou-se que 26 (38,2 \%) alunos da Educativa definiram estruturalmente uma proteína ("substância formada por um conjunto de aminoácidos") e 5 (7,4\%) alunos, funcionalmente ["proteína é uma estrutura que produzimos e podem ter diversas funções: estrutural (formar tecidos), enzimática, hormonal, etc".]. Dos alunos do Álvaro Guião, apenas 3 (4,3 \%) definiram proteínas estruturalmente; dessa escola, 20 (30,8\%) alunos não souberam ou não responderam a questão.

Com respeito às fontes de proteínas $(\mathrm{Q}$. 2a), percebemos uma tendência dos alunos em associar proteínas aos alimentos de origem animal, como carnes $(74,4 \%)$, leite $(57,9 \%)$ e ovos $(42,1 \%)$, embora cerca de $70 \%$ dos alunos tenham afirmado na questão $2 \mathrm{~b}$ que vegetais como verduras e legumes também faziam parte da lista de alimentos ricos em proteínas. 
Em contrapartida, ao serem questionados (questão 2c) sobre a presença de proteínas no corpo humano e de outros organismos, um número considerável de alunos $(33,8 \%)$ não respondeu à questão. Os demais, ao referirem-se às estruturas formadas ou compostas por proteínas, mencionaram tecidos/anexos como cabelo $(21,8 \%)$, músculos $(16,5 \%)$, pele $(15,8 \%)$ ou unha $(11,3 \%)$, percebendo-se uma tendência em entenderem as proteínas apenas como 'construtoras' de tecidos, portanto uma função prioritariamente estrutural.

Com isso a questão 2 indicou certa dificuldade por parte dos alunos em relacionar os tipos de proteínas encontradas nos alimentos com os encontrados no corpo humano. Ou seja, apesar de 89 alunos (66,9\%, questão $2 b)$ afirmarem que as proteínas estão presentes também em legumes e verduras, somente em torno de 6 a $28,6 \%$ dos alunos (questão 2 a) citaram espontaneamente alimentos de origem vegetal (verduras, legumes, frutas, feijão, cereais, soja e arroz) como fonte de proteínas. A "carne", por exemplo, foi o alimento mais citado como fonte de proteínas $(74,4 \%$, questão $2 a)$, em contrapartida, na questão 2c, "músculo" foi citado espontaneamente por apenas $16,5 \%$ dos alunos como constituinte estrutural de organismos.

Percebemos com a questão 4 que grande parte deles não entende 0 processo de digestão, ao constatar que 55 (41,4\%) não responderam a essa questão, sendo que destes, 38 pertenciam ao Álvaro Guião. Dos 49 (36,8\%) alunos que mencionaram a quebra das proteínas antes de serem absorvidas pelo organismo, 38 eram do colégio Educativa. As professoras responsáveis pelas turmas informaram que o conteúdo relativo ao processo de digestão no homem é tratado no $3^{\circ}$ ano do ensino médio, ainda que esse conteúdo, de modo menos aprofundado, também seja parte do currículo de Ciências do ensino fundamental. 
Quanto à associação de algumas doenças/deficiências relacionadas às proteínas (Q. 6) também percebemos um número considerável de alunos que não respondeu ou não sabia (49,6\%), sendo a maioria do Álvaro Guião (que corresponde a $36,1 \%$ do total de alunos), dificultando o apontamento de uma tendência, mesmo porque as doenças listadas são bastante diferentes entre si. No entanto podemos destacar o alto índice de citações de 'anemia'. Os casos mais comuns de anemia resultam da falta de ferro no organismo, resultando na falta da capacidade do organismo de transportar oxigênio, uma vez que a hemoglobina, uma proteína presente nas hemácias, possui em seu sitio de ligação ao oxigênio, um átomo de ferro. Na falta de ferro, o oxigênio não consegue ligar-se à hemoglobina. Nesse caso temos uma associação da doença a uma proteína, embora secundária, já que a causa principal está ligada à falta de ferro. Apesar disso, não é possível assumir que os alunos estabeleçam uma relação direta da doença com a hemoglobina/ hemácia. Doenças associadas à falta de proteínas específicas, como diabete e albinismo, também foram lembradas por $11,3 \%$ e $10,5 \%$ dos alunos que, neste caso, eram todos da Educativa. Citações de doenças como osteoporose, 'atrofiamento' muscular, doenças da pele, podem ter sido feitas por conta da associação da presença de proteínas em tecidos como o ósseo, muscular e da pele, conforme resultados observados na questão 2 c.

\subsubsection{Verificação da aprendizagem: uma comparação entre o questionário diagnóstico e as pré e pós-entrevistas dos alunos selecionados}


Nesta etapa do trabalho, optamos por analisar os dados de apenas uma turma de cada escola - $2^{\circ}$ G do Álvaro Guião e $2^{\circ}$ B da Educativa - e isso se deveu aos motivos apresentados a seguir. A etapa da aplicação do jogo aos alunos selecionados das referidas turmas mostrou-se mais rica em interações e, portanto, com possibilidades de fornecer mais elementos para a interpretação dos dados. Além disso, a quantidade de dados gerada a partir das entrevistas (pré e pós) seria menor e, portanto, mais adequada para o tipo de análise proposta (qualitativa). Ponderamos que a escolha feita não comprometeria a qualidade dos dados e análises.

Dessa forma o objetivo foi investigar possíveis evoluções conceituais ao longo do processo, comparando-se os dados obtidos com o questionário diagnóstico às pré e pós-entrevistas feita com os alunos da amostra. Em outras palavras procuramos identificar nos registros escritos e nas falas dos alunos, elementos que pudessem indicar uma ampliação da definição e função das proteínas (por exemplo, incorporação de novos termos, definições e informações) originados do jogo.

Os dados foram organizados em tabelas de forma a facilitar a visualização global das respostas dadas pelos alunos e assim de todo o processo. Optou-se por selecionar as questões do questionário diagnóstico, bem como os trechos das entrevistas, que remetiam ao tema 'proteínas', por englobarem as discussões e/ou eventos proporcionados pelo jogo. A análise dos dados foi feita levando-se em conta cada aluno separadamente e, para preservar sua imagem, seus nomes verdadeiros não foram revelados, sendo substituídos por pseudônimos.

Analisando a Q.1b da tabela 4.4, no que se refere à pré-entrevista, vemos que ao afirmar que "proteína serve pro músculo"... "serve para os músculos fazerem os movimentos", o aluno James apresentou uma definição de proteína baseada em 
sua função. A definição apresentada pelo aluno privilegia apenas as proteínas com função estrutural, apesar de, mais adiante, admitir que não existe apenas uma função atribuída às proteínas, alegando que isso se deve ao fato de não existir apenas um tipo de proteína e sim vários e assim cada tipo exerceria uma função diferente. Essa relação da proteína com os músculos pode ser vista também em Q.2b e Q.6, em resposta ao questionário diagnóstico. Porém, a pós-entrevista revelou que, por meio das situações-problema proporcionadas pelo jogo (representadas pelas cartas-objetivo), houve uma ampliação destes conceitos, em especial pela situação resolvida pelo aluno James (síntese da proteína Melanina, da pele), bem como pelas discussões promovidas por meio das interações (alunoaluno, aluno-pesquisador).

Tabela 4.4 - Aluno James (EEAG): Respostas ao questionário diagnóstico e trechos das pré e pósentrevistas.

Q.1b O QUE E UMA PROTEÍNA?
Questionário
Não respondeu
Pré-entrevista
Quando questionado sobre o que para ele era uma proteína
"Então, isso eu não estou conseguindo lembrar, assim né, mas pelo que eu lembro... eu vou chutar
assim mais ou menos... é que proteína serve pro músculo, acho que... é que eu não estou
conseguindo lembrar muito... serve para os músculos fazerem os movimentos, um negócio assim...
é que eu não estou conseguindo lembrar agora."
Quando questionado se lembrava de algumas funções das proteínas
"Funções da proteína...? Ah, então, agora, assim de cara não lembro... não estou conseguindo
lembrar."
Quando questionado se ele achava que as proteínas tinham apenas um tipo de função ou vários
"Pelo que mais ou menos assim vou chutar, eu acho que ela tem mais de uma função no
organismo, não tem só uma função específica, por que não tem só um tipo de proteína, tem vários
tipos de proteínas, vários modos de se adquirir proteína, não é só um jeito né. Isso é o que eu acho
assim."

* Pré-entrevista

Não consta

Q2b. ONDE PODEMOS ENCONTRAR PROTEÍNAS, ALÉM DOS ALIMENTOS?

* Questionário

"espermatozóides, músculos, leite materno"

* Pré-entrevista

Ao ler com ele a resposta dada ao questionário

"Hum... não lembro. Foi o que eu lembrei assim na hora, agora eu não lembro." 
Continuação

* Pós-entrevista

Foi perguntado se ele onde podemos encontrar proteínas em nosso organismo e se o jogo ajudou de certa forma

"Bom, eu já sabia que tinha... eu tive isso no ano passado. Pra mim, o que eu vi no jogo eu já sabia... o básico que a gente aprende de proteínas."

Se ele poderia destacar onde podemos encontrar proteínas

"Ah, na pele né, melanina, em verduras, legumes, grãos como feijão, na carne, no leite, é o que eu lembro agora... frutas..."

E em estruturas... lembrar das cartas-objetivo

"De lá eu não lembro muito. Eu só lembro da minha..."

"Melanina... no corpo da gente deve ter no estômago, porque é onde vai né... mais eu não lembro muito bem assim."

\section{Q3a. QUAL O GRANDE PAPEL DAS PROTEÍNAS?}

\section{* Questionário}

"São as proteínas que mantém nosso corpo em ordem, são elas que são responsáveis por manter nosso corpo são."

\section{* Pré-entrevista}

Não foi discutido, uma vez que a conversa "tomou outro rumo" e o aluno já começou a responder a próxima questão e depois não retornamos

\section{* Pós-entrevista}

Ao perguntar qual seria o grande papel das proteínas?

"Cada proteína tem uma função diferente no nosso organismo. Porque nosso organismo tem acho que 23 tipos de proteínas diferentes..." (querendo dizer 23 aa)

"é importante sim, tem uma doença, que é a atrofia muscular que na falta de uma proteína a pessoa pode ficar sem movimento..."

Relacionado ao seu objetivo

"Então, dar cor para a nossa pele, proteger também dos raios solares, do ultra-violeta, eu acho... au acho que é só, que eu me lembre."

\section{Q.4 COMO AS PROTEÍNAS SÃO ABSORVIDAS POR NOSSO ORGANISMO?}

\section{* Questionário}

"As proteínas são absorvidas pelo estômago depois elas sofrem a quebra para poderem ir ao sangue."

\section{* Pré-entrevista}

O que ele entende por processo de digestão e como as proteínas são absorvidas

"Eu não lembro muita coisa, eu só lembro disso, que o suco gástrico do estômago quebra a proteína, em vários pedaços, não pode digerir ela inteira, tem que quebrar, depois ela vira energia se eu não me engano, é que eu não estou conseguindo lembrar direito."

\section{* Pós-entrevista}

Com relação aos 'ingredientes' que a célula precisa para sintetizar uma proteína

"Ah, aminoácidos!"

Por que precisamos ingerir proteínas?

"Porque o nosso organismo tem três jeitos de absorver proteínas: A primeira é que ele faz o que ele precisa, só que não são todas, aí tem umas que são encontradas nos alimentos... tem que comer, pois o corpo não produz e tem que pegar dos alimentos."

Ao ser questionado se as proteínas serão absorvidas inteiras

"Não ta inteira né, ele quebra em pedaços..."

Que pedaços são esses

"Não sei, acho que são aminoácidos... eu não lembro direito."

\section{Q.5 AS CÉLULAS SÃO CAPAZES DE SINTETIZAR PROTEÍNAS?}

\section{* Questionário}

a. "Sim, pois existem proteínas que são fabricadas pelas células e outras adquiridas por alimentos."

b. Analogia

\author{
Gaveta \\ Livro de receitas \\ Receita \\ Ingredientes
}

\begin{tabular}{cc}
\hline Questionário & Pré-entrevista \\
\hline Núcleo & OK \\
DNA & OK \\
RNA & Não lembrava \\
Aminoácidos & OK \\
\hline
\end{tabular}




\section{Pós-entrevista}

Conclusão

Resumo das etapas do processo de síntese protéica, desde onde começa

"Então, começa na célula, no DNA, o DNA se divide... quer dizer, o DNA vira RNA lá, aí tem todo aquele processo, aí ele transcreve em RNA pra virar uma proteína... pega o trio e transforma em proteína e quando transforma em proteína vai para o local específico."

\section{Q.6 RELAÇÃO ENTRE AS DEFICIÉNCIAS COM PROTEÍNAS}

\section{* Questionário}

"Atrofiamento muscular."

* Pré-entrevista

Ao ser perguntado porque ele acreditava ter relação com proteína

"Então eu não lembro, eu sei que essa doença tem a ver, mas eu não sei o porquê. Também sei que aquela doença da pele lá, que tira a cor da pele, que agora eu não lembro o nome... vitiligo, problema de visão, agora porque eu não lembro."

* Pós-entrevista

Lembrando de sua carta-objetivo, você conseguiu estabelecer uma relação entre proteínas e algumas deficiências?

"Não lembro... o meu era melanina, mas eu não lembro se tinha problema."

Com respeito à Q.2b, em que no questionário diagnóstico o aluno James respondeu que as proteínas podiam ser encontradas nos "espermatozóides, músculos, leite materno", na pós-entrevista o aluno afirmou "ah, na pele né, melanina" "(...) Eu só lembro da minha... melanina... no corpo da gente deve ter no estômago, porque é onde vai né...". Nesse caso o jogo proporcionou ao aluno o contato com outros tipos de proteínas, além da apropriação de informação, como o nome da proteína, por exemplo. Com respeito ao papel das proteínas no nosso organismo (relativo à Q.3a) na pós-entrevista o aluno acrescenta “(...) dar cor para a nossa pele, proteger também dos raios solares, do ultra-violeta, eu acho...". Nesse caso percebe-se a ampliação do conhecimento no que se refere às funções das proteínas, que não somente estrutural.

Ao descrever o que acontece com as proteínas no processo de digestão, o aluno demonstrou, no questionário diagnóstico (Q.4), ter noção de metabolismo de proteínas, ao afirmar que "sofrem quebra para poderem ir ao sangue", embora não relacione o produto dessa quebra aos aminoácidos (mesmo fazendo a relação dos aminoácidos com os 'ingredientes' necessários para a síntese protéica, na analogia da Q.5). Na pós-entrevista (Q.4) o aluno não somente fez a relação ingredientes- 
aminoácidos no processo de síntese protéica como os identificou como produto da ‘quebra' das proteínas no processo de digestão.

Através da interpretação feita pelo aluno da analogia contida na Q.5 do questionário diagnóstico, fazendo corretas as associações propostas, o mesmo demonstrou compreensão da analogia o que nos faz supor a sua compreensão de parte do processo de síntese protéica. Na pós-entrevista, ao ser solicitado que resumisse o processo de síntese protéica, pudemos perceber em sua fala alguns elementos que faziam alusão às etapas do jogo. Após ter mencionado o processo de transcrição, James descreveu o processo de tradução (sem mencionar o termo) como sendo "pega o trio e transforma em proteína" e finalmente "quando transforma em proteína vai para o lugar específico", referentes à etapa 3 do jogo em que, utilizando a tabela do código genético, tinham que traduzir as trincas de nucleotídeos da fita do RNA mensageiro em uma seqüência de aminoácidos, e à etapa 5 (destinar proteína) em que os alunos tinham que encaminhar sua proteína formada ao seu 'local de atuação', intra ou extracelularmente.

No entanto devemos destacar a manutenção de uma concepção alternativa a respeito da produção de proteínas pela célula. Em resposta à Q.5a do questionário diagnóstico, James afirma que a célula produz proteínas, pois "existem proteínas que são fabricadas pelas células e outras adquiridas por alimentos" e respondendo à Q.4, na pós-entrevista, acrescenta que "nosso organismo tem três jeitos de absorver proteínas: A primeira é que ele faz o que ele precisa, só que não são todas, aí tem umas que são encontradas nos alimentos... tem que comer, pois o corpo não produz e tem que pegar dos alimentos". Dessa forma, não fica claro, pelo discurso do aluno na pós-entrevista, se ao afirmar que algumas proteínas não são sintetizadas pelas células, devendo ser adquiridas por meio da alimentação, estava querendo se referir 
aos aminoácidos essenciais ou se mesmo entendendo que as proteínas sejam sintetizadas a partir de aminoácidos e que no processo de digestão as proteínas são ‘quebradas' em aminoácidos, não compreende o processo.

O aluno Maurício define proteína (tab. 4.5, Q.1b do questionário diagnóstico) como “... uma molécula formada por um conjunto de aminoácidos” e “... é criada pelos genes". Na pré-entrevista, ao ser confrontado com sua definição no questionário diagnóstico, o aluno teve a oportunidade de reformular sua resposta, justificando que "o gene contém um código pra sintetizar proteína, não que o gene cria proteína. Ele tem o código”.

Tabela 4.5 - Aluno Maurício (EEAG): Respostas ao questionário diagnóstico e trechos das pré e pósentrevistas.

\section{Q.1b O QUE É UMA PROTEÍNA? \\ * Questionário}

"Proteína é uma molécula formada por um conjunto de aminoácidos. A proteína é criada pelos genes que por sua vez localizam no DNA. A proteína é essencial para a vida, pois ela é quem cria matéria."

\section{* Pré-entrevista}

Enquanto lia sua resposta ao questionário...

"Mas ta errado isso aqui" (...) "Porque o gene contém um código pra sintetizar proteína, não que o gene cria proteína. Ele tem o código".

O que é um gene?

"Gene é uma cadeia de nucleotídeos, quer dizer, um pedaço de uma cadeia de nucleotídeos que contém informação pra sintetizar proteínas. Eu não estou lembrado se o gene é uma seqüência de nucleotídeos, que dali vai sair uma proteína" (...) "Ele é um pedaço do DNA. É que pra definir só um gene é difícil, mas se você for definir na síntese de proteína, dá pra falar que a RNA polimerase vem, vê onde está o gene... desfaz as ligações, aí dá pra entender um pouquinho melhor."

\section{* Pós-entrevista}

Não consta

Q2b. ONDE PODEMOS ENCONTRAR PROTEÍNAS, ALÉM DOS ALIMENTOS?

\section{* Questionário}

"Membrana plasmática, cromossomos..."

\section{* Pré-entrevista}

Ao perguntar onde poderíamos encontrar proteínas em nosso organismo

"Membrana plasmática eu não tenho certeza, cromossomo sim. Porque cromossomo é DNA enrolado em proteína... então tem proteína". (...) "Os ossos é uma estrutura. A estrutura óssea acho que tem proteína, suor eu acho que não tem. Então eu acho que só. O resto de tecidos assim que a gente tem eu acho que todos praticamente são formados de proteínas. O que é mais certeza são os ossos". (...) "Tecidos acho que todos são de proteínas".

\section{* Pós-entrevista}

Ao perguntar se baseado no jogo ele era capaz de me dizer onde encontramos proteínas

"Então, todos os tecidos do nosso organismo são constituídos de proteínas né e no jogo tinha vários exemplos... o que eu peguei era do movimento do tendão, que tinha um cara tentando jogar bola e precisava de uma quantidade maior de proteína pra curar mais rapidamente aquele ferimento. $\mathrm{E}$ eu tenho essa base, que todos os tecidos, que na verdade forma o nosso organismo, são compostos por proteínas". (...) "o que eu peguei foi só esse, mas o que os outros pegaram eu não lembro". 
Q3a. QUAL O GRANDE PAPEL DAS PROTEÍNAS?

Continuação

\section{* Questionário}

"São elas quem fabricam matéria no nosso organismo"

\section{* Pré-entrevista}

Ao ler sua resposta do questionário e perguntar se ele achava que as proteínas possuem apenas uma função.

"Criar matéria como eu falei é criar pele, osso, tudo. Eu acho que só essa daí". (...) "Tem vários tipos" (...) "Não. Tipo, a queratina define a cor da pele, do cabelo, outro tipo de proteína define outras coisas. Glicose... não é glicose, como é que chama aquela da diabete?... insulina. Cada tipo de proteína tem um tipo de função. Ainda que a insulina é sintética né, fabricada por células."

\section{* Pós-entrevista}

Lembrando do jogo, perguntei qual seria o papel das proteínas e se ele ajudou.

"Ah, as proteínas têm várias funções e cada uma exerce uma. De restaurar vamos supor, que nem o que eu peguei, o tendão do pé do moleque... só que a grande, que eu tenho com... pra que serve as proteínas, é pra fazer matéria, vamos supor, é um dos elementos principais da constituição da matéria. Pra mim a base que eu tenho é essa". (...) "cada uma tem uma função. Porque cada gene define uma proteína, cada proteína tem sua função no nosso organismo. Que nem, tipo, se você for dar exemplo da pele, o tecido da pele, é composto por uma proteína, já a insulina, que é responsável pela quantidade de... esqueci o nome... do açúcar". (...) "Tem várias, tem a queratina, que dá a cor do cabelo, a cor dos olhos, da pele... cada uma tem sua função".

\section{Q.4 COMO AS PROTEÍNAS SÃO ABSORVIDAS POR NOSSO ORGANISMO?}

\section{* Questionário}

"No processo de digestão, os alimentos são quebrados em micropartículas, depois disso somente as moléculas que tem proveito são absorvidas."

\section{* Pré-entrevista}

Quando perguntado a respeito do processo de digestão das proteínas

"a gente vai absorver não tenho certeza se tudo, mas uma boa parte vai absorver, pra sintetizar proteína.

Quando questionado se nosso organismo absorve a proteína inteira

"Não, daí eu não tenho certeza". (...) "Então, eu acho que ela vai ser quebrada ainda... subdividida...".

Será quebrada em que?

"Não sei se em pedaços, não sei como é que é... porque mesmo uma cadeia de aminoácido é muito menor que o pozinho que vem, dentro daquilo lá... como vem a proteína comprada, daí você vai tomar... como eu falei tudo que é proteína é digerido de um jeito no nosso corpo e tudo o que não é proteína... esqueci o nome do lugar sabe? Por exemplo lipídeos sei lá pra onde ele vai... no lugar onde ele tem proveito ele absorve".

\section{* Pós-entrevista}

Ao ser perguntado do que é constituída um proteína.

A proteína é constituída por uma cadeia de aminoácidos. Aminoácidos são os nucleotídeos que compõe o DNA, o conjunto deles formam os aminoácidos. Só que depois de passado por um processo de transcrição, de separar, todos esses processos são importantes para a formação da proteína.

Por quê precisamos ingerir proteínas?

“Eu lembro da síntese de proteína, agora como nosso organismo absorve essa proteína e usa na hora de sintetizar... Porque se agente já absorve a proteína já pronta, não tem porque sintetizar né?" (...) "Eu lembro que o professor deu que... tem que... o que vai servir pra gente, o resto vai ser eliminado". (...) "Não entra na cabeça como elas vão absorver, pra que absorver proteína... já vitaminas, carboidratos, esse tipo de coisa, sim né, tem uma necessidade, agora proteína eu não consigo entender".

\section{Q.5 AS CÉLULAS SÃO CAPAZES DE SINTETIZAR PROTEÍNAS?}

\section{* Questionário}

a. "Não." 
Pré-entrevista

Conclusão

Por que ele achava que a célula não fosse capaz de fabricar proteínas e se vinha tudo da alimentacão

"A proteína é fabricada no DNA, que ta na célula, não que ela é fabricada, contém o código genético, como eu falei, no DNA, que chama genes, que vem a polimerase vê onde está o gene, desfaz as ligações, vem o RNA copia e leva aquilo lá, deixa no citoplasma, vem o RNA trasportador, carrega o ribossomo e faz a síntese de proteína. A célula não faz a proteína, ocorre na célula, mas não é a célula que faz. Bom aí eu não tenho certeza se vem uma mensagem do cérebro e fala... deixa na célula e fala... que ta precisando de proteína, porque é tudo por mensagem eletrônica..."

\section{* Pós-entrevista}

Resumo das etapas da síntese

"Pra sintetizar uma proteína começa num processo de transcrição, que ele fala em codificação da linguagem de DNA pra RNA, isso passa para o RNA... a linguagem codificada em RNA passa para ter uma seleção de uma trinca de nucleotídeos que vai ser levada pelo RNA transportador até o citoplasma pra haver a síntese de proteínas com os ribossomos."

O Ribossomo vai fazer a leitura?

"Isso, ele que vai fazer a etapa final ali... de formar cada conjunto de aminoácido."

\section{Q.6 RELAÇÃO ENTRE AS DEFICIÉNCIAS COM PROTEÍNAS}

\section{* Questionário}

"Anemia."

* Pré-entrevista

Não acrescentou nada

* Pós-entrevista

Pedi que relacionasse a proteína que ele havia formado com alguma deficiência

"Em termos de formar proteínas, sim, imaginar que vai reconstituir aquele pedaço que estava danificado."

O que aconteceria ao menino

"Não ia reconstituir aquele pedaço que estava danificado."

"Acho que ele ia ficar machucado a vida inteira."

Com relação ao papel que as proteínas podem exercer no organismo (Q. 3a), Maurício apresentou a concepção de que "elas fabricam matéria". Embora na pré-entrevista tenha mencionado que existem vários tipos de proteínas, com outras funções diferentes (citando a insulina, que é um hormônio), a concepção de que as proteínas "fabricam matéria" foi a que prevaleceu, sendo reforçada na pósentrevista. Podemos perceber essa predominância também quando o aluno, ao definir onde as proteínas podem ser encontradas (Q.2b), privilegia os tecidos, atribuindo às proteínas somente a função de construtoras de tecidos e, ao relacionar deficiências às proteínas (Q.6), menciona a incapacidade de regeneração de tecidos danificados devido à ausência de alguma proteína. Com relação às situaçõesproblema apresentadas no jogo, só lembrou da sua, relacionada ao tendão. 
O aluno, ao descrever o processo de digestão das proteínas (Q.4), citou "quebra em micro partículas" e "absorção de moléculas que tem proveito"; na pósentrevista, questionou "não entra na cabeça como elas vão absorver, pra que absorver proteína...". Apesar de demonstrar segurança ao definir uma proteína em termos estruturais (molécula formada de aminoácidos) (Q.1b), apresentou dificuldade em aplicar esses conceitos em outro contexto, no caso a digestão (Q. 4).

Maurício discute o processo de síntese protéica em vários momentos (Q.1b, Q.4 e Q.5). Em especial na Q.5 do questionário diagnóstico, apresentou a seguinte descrição: "vem a polimerase vê onde está o gene, desfaz as ligações, vem o RNA copia e leva aquilo lá, deixa no citoplasma, vem o RNA transportador, carrega o ribossomo e faz a síntese de proteína”. Analisando essa fala percebemos o uso de termos científicos, por parte do aluno, como 'polimerase' (referindo-se a RNA polimerase), 'RNA transportador', 'gene', embora o faça de maneira um pouco confusa. Porém na pós-entrevista, quando solicitado para resumir o processo de síntese protéica, o mesmo declarou:

\footnotetext{
"Pra sintetizar uma proteína começa num processo de transcrição, que ele fala em codificação da linguagem de DNA pra RNA, isso passa para o RNA... a linguagem codificada em RNA passa para ter uma seleção de uma trinca de nucleotídeos que vai ser levada pelo RNA transportador até o citoplasma pra haver a síntese de proteínas com os ribossomos."
}

Podemos perceber uma melhor organização de suas idéias e não somente uma aglomeração de termos científicos sem muito sentido. Houve a menção do processo de 'transcrição' como sendo 'codificação da linguagem de DNA para RNA'; o RNA transportador foi relacionado com o 'carreamento de trincas' e não do ribossomo, como havia declarado anteriormente; e os ribossomos como participantes do processo de síntese protéica. 
A tabela 4.6, referente ao aluno Michael, mostra que antes da interação com o jogo, o conceito de proteína construído pelo aluno (Q.1b) levava em consideração aspectos estruturais e funcionais da mesma. No questionário diagnóstico, o aluno inicia sua definição de proteína como "É o conjunto de aminoácidos...”; entretanto, teve dificuldade, na pré-entrevista, em esclarecer o que seriam os aminoácidos. Em termos funcionais remetia somente a função estrutural, ao afirmar que "tinham a função de construtores e reparadores do nosso organismo". No entanto podemos notar que após o jogo houve uma ampliação desses conceitos: "Antigamente eu só achava que era construir e reparar, mas agora vejo que não é só isso, por exemplo a insulina, outros hormônios, a 'criatina' (referindo-se a queratina), presente no cabelo, unha, são mais para manter o organismo mesmo..."(Q.3a).

Tabela 4.6 - Aluno Michael (EEAG): Respostas ao questionário diagnóstico e trechos das pré e pósentrevistas.

Q.1b O QUE É UMA PROTEÍNA?
"É Q o conjuntionário de aminoácidos que exercem função de construtores e reparadores no nosso
organismo."

* Pré-entrevista

O que seria esse conjunto de aminoácidos

"É que eu aprendi e na hora eu não lembrava bem assim o que era, eu lembro que das outras aulas da professora ela falou que a proteína quando ela é digerida é quebrada em aminoácidos... aí eu pensei, deve ser um conjunto de aminoácidos, mas explicar assim eu não sei. E o que eu lembrei é que carboidratos tem a função de dar energia, proteína é construir, lipídeo era dar energia e construir, então por isso que eu coloquei."

Pra você a proteína é formada de...

"Aminoácidos. São vários aminoácidos juntos, uma coisa assim."

Com relação as funções que colocou

"Pelo que eu me lembro, no caso quando temos um machucado no tecido, é função da proteína ir lá e reparar... quando tem alguma enfermidade, uma coisa assim. Eu não lembro, faz muito tempo que eu vi isso."

\section{* Pós-entrevista}

Não consta

Q2b. ONDE PODEMOS ENCONTRAR PROTEÍNAS, ALÉM DOS ALIMENTOS?

* Questionário

"Na membrana celular - lipoprotéica"

\section{* Pré-entrevista}

Ao ler com ele a resposta dada ao questionário

"É que eu lembrei que a membrana é lipoprotéica, aí foi só isso que eu lembrei na hora. No momento não lembro mais de nada não."

E em termos de outras estruturas

"Acho que em termos de tecidos mesmo, como a pele, as cartilagens também, mas os ossos eu acho que não, não sei... mas acho que mais na pele mesmo."

E com relação a secrecões, fluidos.

"Não, não sei... se eu estudei eu não lembro." 
Continuação

* Pós-entrevista

Ao perguntar se baseado no jogo ele era capaz de me dizer onde encontramos proteínas e se ele ajudou de alguma forma

"Ajudou... não vou lembrar de todos, mas..."

Se lembrar do seu

"O que eu tinha que fazer era da adrenalina... não, tinha que produzir a insulina, que era pra ajudar

na digestão. Ah, o jogo ajudou sim..."

Ao perguntar qual era sua idéia antes do jogo

"Só nos músculos!!... risos. Aí eu vi no caso da insulina, um hormônio, a 'criatina', no cabelo..."

Relacionada a pele...

"A melanina"

A situação do garoto no quarto escuro...

"No olho."

Foram várias proteínas diferentes

"Pois é, os hormônios, eu nunca tinha pensado assim... ajudou a abrir um pouco a visão que eu tinha sobre as proteínas."

\section{Q3a. QUAL O GRANDE PAPEL DAS PROTEÍNAS?}

\section{* Questionário}

"Eles exercem função de construtores dos tecidos e órgãos. Precisamos delas pra crescermos fortes e saudáveis."

\section{* Pré-entrevista}

Quando questionado se existem outras funções além dessas

"Eu acho que tem, mas eu não lembro. Mas acho que é mais isso mesmo, a construção dos tecidos. Tem aquela parte do DNA que codifica proteína, mas de explicar eu não vou saber não."

\section{* Pós-entrevista}

Quais as funções que as proteínas podem exercer no nosso organismo?

"Antigamente eu só achava que era construir e reparar, mas agora vejo que não é só isso, por exemplo a insulina, outros hormônios, a 'criatina', presente no cabelo, unha, são mais para manter o organismo mesmo..."

No seu caso, se o organismo não produzir insulina...

"Ele não ia conseguir queimar todo o açúcar ingerido..."

Dessa forma está relacionada a qual deficiência?

"Com diabetes"

\section{Q.4 COMO AS PROTEÍNAS SÃO ABSORVIDAS POR NOSSO ORGANISMO?}

\section{* Questionário}

"Durante a digestão as proteínas são 'quebradas' pelas enzimas. Assim ficam menores e podem ser absorvidas."

\section{* Pré-entrevista}

Ao ler sua resposta ao questionário diagnóstico

"A digestão, pelo que eu aprendi, ela começa na boca, com a mastigação e a saliva, depois eu não lembro onde vai as enzimas, se eu não me engano no estômago... no estômago tem enzimas e depois ela é absorvida no intestino, se eu não me engano."

No caso elas são quebradas em quê?

"Em aminoácidos... como eu disse, as partes menores. Eu só não sei se os aminoácidos são maiores e são quebrados novamente... só sei isso, se ainda é mais uma vez."

O que o nosso corpo está interessado? Nas proteínas ou na "matéria prima"?

"Pelo que eu entendi até agora, os aminoácidos se juntam com os ribossomos pra fazer a divisão celular, pra crescer... Pelo que eu entendi... até agora."

\section{* Pós-entrevista}

Quais os ingredientes que uma célula precisa?

"Primeiro tem a cadeia de nucleotídeos, depois formam os aminoácidos e depois os aminoácidos se juntam no ribossomo para fazerem a proteína."

Por que devemos ingerir proteínas, já que elas precisam de aminoácidos?

"A gente ingere proteína, aí a saliva e tipo outros... quebram a proteína em aminoácidos, pra poder ter vários aminoácidos pra formar novas proteínas para as células."

Você acha que o jogo ajudou de alguma forma?

"Não foi bem o jogo, eu lembro que conversamos durante o jogo e você explicou como funcionava, mas ajudou sim." 
Q.5 AS CÉLULAS SÃO CAPAZES DE SINTETIZAR PROTEÍNAS?

Conclusão

\section{* Questionário}

a. "Sim, os ribossomos e o RNA atuam na síntese de proteínas dentro da célula".

b. Analogia

Gaveta

Livro de receitas

Receita

Ingredientes

\begin{tabular}{c}
\hline Questionário \\
\hline Núcleo \\
RNAm \\
Mensagem do RNA para os \\
ribossomos \\
Aminoácidos
\end{tabular}

Aminoácidos

\section{Pré-entrevista}

Núcleo

“... o DNA, não seria o RNA né?..."

"Seria o gene"

OK

\section{Pós-entrevista}

Resumo das etapas do processo de síntese protéica, desde onde começa

"No núcleo. Aí tem a cadeia de nucleotídeo, aí atravessa a carioteca... eu lembro da polimerase, que daí começa a cadeia de nucleotídeo".

Começa a partir do DNA, mas o que se forma?

"Forma a cadeia de nucleotídeos, aí sai do núcleo e vai o ribossomo... o RNA transportador junto pra fazer a seqüência de aminoácidos e depois acaba a proteína".

Qual a última etapa?

"Ela vai pra onde... ou ela é guardada ou ela é expelida, no caso da insulina ela é guardada".

Q.6 RELAÇÃO ENTRE AS DEFICIÉNCIAS COM PROTEÍNAS

\section{* Questionário}

"Anemia, mas não tenho certeza".

* Pré-entrevista

Enquanto lia a resposta dada ao questionário

"Eu acho que eu já vi algumas doenças causadas pela falta de alguma proteína, mas eu não to conseguindo lembrar".

\section{* Pós-entrevista}

Lembrando das cartas-objetivo... você conseguiria ver a relação entre alguma deficiência e proteína?

"No caso a diabetes, que se você for pensar o corpo não produz a insulina e a pessoa precisa ingerir a insulina pra suprir. E com relação a melanina, tem o albinismo, que é a ausência de melanina e tem outra também que eu não me lembro..."

"O vitiligo".

Vemos essa evolução em seu discurso também com relação à localização da proteína num (Q.2b). Em resposta ao questionário diagnóstico mencionou apenas "membrana plasmática", reforçando o conceito de que a função predominante nas proteínas é a estrutural. Na pós-entrevista vemos uma reformulação em seu modo de pensar, ao admitir que antigamente pensasse que encontrávamos proteínas "só nos músculos!!... risos. Aí eu vi no caso da insulina, um hormônio, a 'criatina' (queratina), no cabelo..." (...) "melanina” (...) "Pois é, os hormônios, eu nunca tinha pensado assim... ajudou a abrir um pouco a visão que eu tinha sobre as proteínas".

Ao descrever o processo de digestão das proteínas pelo organismo (Q.4), no questionário diagnóstico, apesar de mencionar que existiam enzimas que 
quebravam as proteínas, não mencionou nenhum produto dessa quebra. Na préentrevista esclarece que os produtos dessa quebra são os aminoácidos, mas demonstra dúvida se os mesmos também “... são quebrados novamente”. Já na pósentrevista, Michael apresentou bastante segurança ao afirmar que "a gente ingere proteína, aí a saliva e tipo outros... quebram a proteína em aminoácidos, pra poder ter vários aminoácidos pra formar novas proteínas para as células”.

Com a Q.5 podemos perceber que o aluno tinha uma noção de que o ribossomo e o RNA faziam parte do processo de síntese de proteína dentro da célula. Na pós-entrevista, ao resumir as etapas do processo de síntese protéica, além de ampliar sua explicação, o aluno retomou as etapas do jogo em expressões do tipo "lembro da polimerase, que daí começa a cadeia de nucleotídeo" ou "daí sai do núcleo e vai para o ribossomo" (referindo-se à etapa 'atravessar a carioteca') ou "ela é guardada ou expelida" (referindo-se a etapa 'destinar proteína', que no caso do Michael, tinha que formar a insulina, que ficava armazenada em grânulos). Houve uma ampliação também no que diz respeito aos exemplos de doenças relacionadas a proteínas, pois de somente "anemia" no questionário diagnóstico, ampliou para "diabetes" (relacionada à insulina, um hormônio), "albinismo" e "vitiligo" (ambas relacionadas à melanina, na pele).

Analisando as respostas da aluna Priscila (tab. 4.7), detectamos a presença de uma série de imprecisões relativas ao conceito de proteína e ao processo de síntese protéica e, de certa forma, a manutenção de algumas dessas imprecisões ao longo do processo. Para ela "proteína é algo que nos dá energia, é essencial para a nossa sobrevivência e nos dá força para as atividades do cotidiano". Ao relacionar DNA à proteína afirma que “DNA, por exemplo, é formado por proteínas e nós somos o nosso DNA, portanto a importância das proteínas fica clara”. Embora um 
pouco confusa, a aluna relaciona DNA tanto às características fenotípicas de um indivíduo quanto à proteína. Com relação à síntese protéica apresentou algumas divergências. Para a Q.1b, na pré-entrevista, respondeu: "o que eu lembro é que você tem um RNA transportador, que pega os aminoáci... os ribossomos e forma uma cadeia, um códon, com os aminoácidos e aí... isso no RNA mensageiro e depois eu não lembro". Percebemos que a aluna possuía os conceitos separadamente, mas não conseguia relacioná-los ou de alguma forma não faziam sentido para ela. Isso pode ser verificado também ao analisarmos a Q.5a em que a aluna apresentou a noção de que “...o DNA está presente no núcleo das células, onde são produzidas as proteínas." e que os aminoácidos são formados dentro do núcleo. No entanto na pós-entrevista, na tentativa de lembrar as fases do jogo, não conseguiu se expressar direito: "Eu lembro que tinha aquela parte que ela está dentro da célula ainda... dentro do núcleo, depois ela saía..." (se referindo a 'fita' representativa do RNA mensageiro).

Tabela 4.7 - Aluna Priscila (Educativa): Respostas ao questionário diagnóstico e trechos das pré e pós-entrevistas.

\section{Q.1b O QUE É UMA PROTEÍNA?}

\section{* Questionário}

"Proteína é algo que nos dá energia, é essencial para a nossa sobrevivência e nos dá força para as atividades do cotidiano. Nosso DNA, por exemplo é formado por proteínas e nós somos o nosso DNA, portanto a importância das proteínas fica clara".

\section{* Pré-entrevista}

"Somos o nosso DNA"... pedia para explicar um pouco mais.

"É porque é o DNA que mostra todas as nossas características, como nós vamos ser, fisicamente e também por dentro, então..."

Explicar o que seria esse "mostrar"

"Ah! A cor do nosso cabelo, a cor dos olhos... silêncio... não sei".

Qual a relação com proteínas

"Ah! O DNA é formado por proteínas, aminoácidos, então... eu acho que é. Como nós somos praticamente o nosso DNA, nosso corpo praticamente inteiro é formado por proteína, por isso que ela é tão essencial".

Como as proteínas são formadas

"Por... três aminoácidos... porque são três bases... códon".

"(...) mas o que eu lembro é que você tem um RNA transportador, que pega os aminoáci... os ribossomos e forma uma cadeia, um códon, com os aminoácidos e aí... isso no RNA mensageiro e depois eu não lembro".

De onde vem o RNA mensageiro

"Vem do DNA" 
Continuação

* Pós-entrevista

Não consta

Q2b. ONDE PODEMOS ENCONTRAR PROTEÍNAS, ALÉM DOS ALIMENTOS?

* Questionário

"A urina, fígado, rins..."

* Pré-entrevista

Pedindo para pensar um pouco mais em cima do que escreveu no questionário

"Agora pensando, acho que boa parte do nosso organismo se encontra... acho que no sangue também, provavelmente..."

Onde mais

"Órgãos, acho que na vesícula, na bexiga... no fígado e no estômago também porque o que a gente ingere de proteína, uma parte deve ficar lá... e acho que é isso".

\section{* Pós-entrevista}

Ao perguntar se baseado no jogo ele era capaz de me dizer onde encontramos proteínas

"Eu sei que no sangue, no olho, na pele, acho que em quase tudo... tudo a gente encontra".

Q3a. QUAL O GRANDE PAPEL DAS PROTEINAS?

* Questionário

"As proteínas carregam aminoácidos, que são essenciais para o funcionamento adequado do organismo".

\section{* Pré-entrevista}

Para explicar melhor sua resposta do questionário

"Porque as proteínas carregam os aminoácidos que formam praticamente o nosso corpo, porque o DNA... silêncio... é aquilo, que o DNA mostra o que a gente vai ser por fora. Uma operação no DNA muda totalmente seu código genético... então... você, dependendo da quantidade de proteína você pode ter algumas doenças ou ser de um jeito, que se você não tivesse você seria de outro jeito".

\section{* Pós-entrevista}

Qual o grande papel das proteínas dependendo de onde atuarem.

"Por exemplo, no sangue... se não estiver no sangue, ele não coagula, não é? Ela ajuda os órgãos a funcionarem corretamente".

E da pele?

"Ela dá o pigmento da pele".

E com relacão ao sol?

"Porque quando você fica bronzeado, é uma proteção da pele".

Q.4 COMO AS PROTEÍNAS SÃO ABSORVIDAS POR NOSSO ORGANISMO?

\section{* Questionário}

"Eles vão sendo lentamente absorvidas na digestão e o que sobra é eliminado pela urina".

\section{* Pré-entrevista}

Como essas moléculas são absorvidas, inteiras ou não?

"Elas vão uma parte para o sangue, elas se dividem pelo corpo e elas também vão entrar em contato com o DNA né?... acho que é isso".

De que forma?

"Pelo RNA?"

De quais elementos a célula precisa para formar proteínas?

"Aminoácidos"

O que precisa ocorrer no processo de digestão para absorvermos os aminoácidos das proteínas?

"Ela tem que ser separada, os aminoácidos tem que se soltar..."

\section{* Pós-entrevista}

De que é formada a proteína?

"Aminoácidos".

Por que precisamos ingerir proteínas?

"Porque nós somos feitos basicamente de proteínas".

O que precisa acontecer com as proteínas ingeridas para serem absorvidas?

"Precisam ser digeridas".

"Elas vão ser quebradas e cada uma vão para a parte que vão trabalhar!" 
Q.5 AS CÉLULAS SÃO CAPAZES DE SINTETIZAR PROTEÍNAS?

Conclusão

\section{* Questionário}

a. "Sim, o DNA está presente no núcleo das células, onde são produzidas as proteínas."

b. Analogia

\begin{tabular}{ccc} 
& Questionário & Pré-entrevista \\
\cline { 2 - 3 } Gaveta & Núcleo & OK \\
Livro de receitas & DNA & OK \\
Receita & Proteínas & Bases \\
Ingredientes & Aminoácidos & OK
\end{tabular}

\section{Pós-entrevista}

Resumo das etapas do processo de síntese protéica

"Eu lembro que tinha aquela parte que ela está dentro da célula ainda... dentro do núcleo, depois ela saía..."

Dentro do núcleo forma qual molécula?

"Aminoácidos!"

\section{Q.6 RELAÇÃO ENTRE AS DEFICIÊNCIAS COM PROTEÍNAS}

\section{* Questionário}

"Anemia, cegueira noturna, osteoporose, descalcificação dos dentes, mal de Parkinson".

\section{* Pré-entrevista}

Da relacão que havia colocado, por que achava que tinham relacão

"Acho que osteoporose está errado, porque tem a ver com calcificação e não proteína, mas acho que anemia ta certo porque Anemia é falta de glóbulos brancos e isso acho que é falta de uma proteína... essa eu acho que talvez não, mas é causada... uma coisa que ajuda são alguns vegetais, ajuda a prevenir, então talvez tenha a ver com alguma proteína que você tenha que ingerir. Descalcificação nos dentes também não...."

Mal de Parkinson

"Eu acho que tem a ver com a falta de alguma proteína e eu também estava pensando no albinismo que é falta de proteína também".

\section{* Pós-entrevista}

Lembrando das cartas objetivo, relacione algumas deficiências com proteínas.

"Miopia eu acho que está relacionada né, com a falta de uma proteína".

Percebemos algumas evoluções conceituais, embora bastante pontuais. Antes do jogo Priscila tinha uma visão bastante limitada com relação à localização das proteínas em nosso organismo (Q.2b), respondendo de forma genérica "nos órgãos". Após o jogo, citou "no sangue, no olho, na pele, acho que em quase tudo... tudo a gente encontra", lembrando-se das situações-problemas proporcionadas pelo jogo. Ao se referir à função das proteínas (Q.3a) no questionário, atribuiu a importância dos aminoácidos ao bom funcionamento do organismo, reforçando essa idéia na pré-entrevista. Na pós-entrevista mencionou funções como "pigmentar e proteger a pele”, em alusão ao seu objetivo no jogo, que era a síntese da proteína melanina, presente na pele. 
O aluno Paulo (tab. 4.8) não apresentou dificuldade ao definir uma proteína como "uma estrutura molecular composta de aminoácidos" (Q.1b) e que "todo ser vivo produz proteína... animal, planta, bactéria...” (Q.2b), mas teve dificuldade com respeito às funções desempenhadas pelas proteínas no nosso organismo, associando somente à energia (Q.3a). No entanto, ao ser entrevistado após o jogo, lembrou-se que a adrenalina aumenta a circulação sangüínea e a melanina, estaria relacionada ao pigmento da pele.

Tabela 4.8 - Aluno Paulo (Educativa): Respostas ao questionário diagnóstico e trechos das pré e pós-entrevistas.

\section{Q.1b O QUE É UMA PROTEÍNA?}

\section{* Questionário}

"Uma estrutura molecular composta por aminoácidos e sintetizada por ribossomos (+ RNA)".

\section{* Pré-entrevista}

Pedi para ele explicar um pouco melhor o que quis dizer no questionário

"Bom, o RNA mensageiro junto com o Ribossomo, meio que atrai o RNA transportador com os aminoácidos. Cada RNA transportador, juntando com outro aminoácido, vai sintetizando a proteína. Pelo menos é isso que eu me lembro".

\section{O RNA mensageiro vem de onde?}

"Tanto o RNA mensageiro quanto o transportador vem... são sintetizados no núcleo, a partir da fita do DNA".

* Pós-entrevista

Não consta

Q2b. ONDE PODEMOS ENCONTRAR PROTEÍNAS, ALÉM DOS ALIMENTOS?

\section{* Questionário}

"Todo ser vivo produz proteínas. A membrana plasmática de uma célula é composta por proteínas".

\section{* Pré-entrevista}

Pedindo para se lembrar, ser mais específico em sua resposta.

"Qualquer ser vivo praticamente né... qualquer animal, planta, bactéria..."

Dei o exemplo de um inseto, pedi que relacionasse alguma proteína.

"Ah! Eu não sei nome de proteína alguma. Desculpe, mas... mas deve produzir proteína também".

\section{* Pós-entrevista}

Pedi que falasse onde podemos encontrar proteínas em nosso organismo e se o jogo ajudou.

"Bom, proteínas... qualquer célula... qualquer célula produz proteína. Bom, o jogo meio que ajudou a relembrar, a visualizar um pouquinho o processo..."

Pedi que se lembrasse das situacões, ao menos da que ele formou.

"A minha foi... nossa esqueci... acho que foi... era adrenalina? Tinha alguém que estava fazendo adrenalina. Não, eu não lembro qual que é".

\section{Q3a. QUAL O GRANDE PAPEL DAS PROTEÍNAS?}

\section{* Questionário}

"Produção de energia (esqueci o resto)".

\section{* Pré-entrevista}

O aluno não soube acrescentar, só sabia que as proteínas tinham várias funções, mas não sabia quais eram. 
Continuação

\footnotetext{
Pós-entrevista

Perguntei sobre o papel que as proteínas podem exercer no organismo.

"Bom, adrenalina o que ela faz? Ela aumenta a circulação do sangue, seria isso?".

"Tem a melanina também que produz o pigmento de pele né... Ah, vários outros".

Q.4 COMO AS PROTEÍNAS SÃO ABSORVIDAS POR NOSSO ORGANISMO?

* Questionário

"São quebradas em seus aminoácidos de origem para a síntese de proteínas próprias".

* Pré-entrevista
}

Pedi que falasse um pouco mais

"Ah! No estômago você quebra qualquer proteína que entra e solta nos seus aminoácidos que era antes de ser uma proteína e depois seu corpo sintetiza outra proteína com os aminoácidos da proteína anterior".

Então porque ingerimos proteínas? Para que vão servir?

Mais aminoácidos

* Pós-entrevista

O que a célula precisa para sintetizar proteínas?

"Aminoácidos"

Por que precisamos ingerir proteínas?

"Pra quebrar os aminoácidos que os outros animais ou plantas produzem, pra ter aminoácidos pra gente sintetizar as nossas proteínas".

\section{Q.5 AS CÉLULAS SÃO CAPAZES DE SINTETIZAR PROTEÍNAS?}

\section{* Questionário}

a. "As células são fábricas de proteínas".

b. Analogia

\begin{tabular}{ccc} 
& Questionário & Pré-entrevista \\
\cline { 2 - 3 } Gaveta & Núcleo & OK \\
Livro de receitas & RNAm & DNA \\
Receita & RNAt & RNAm \\
Ingredientes & Aminoácidos & OK
\end{tabular}

\section{Pós-entrevista}

Resumo das etapas do processo de síntese protéica

"Começava lá com o... como é que chamava?... caramba eu esqueci, era a primeira cartinha... "

RNA Polimerase

"Isso, polimerase!! Só tinha visto aquilo no jogo, nunca tinha visto antes. Enfim..."

"É... pega aos aminoácidos do... quer dizer, é o RNA né..."

"Isso, vai formar o RNA dentro do núcleo. O RNA sai, vai para o ribossomo, certo o ribossomo?"

"Aí lá pega o RNA mensageiro, pra poder fazer... pegar os aminoácidos..."

"O RNA transportador carrega os aminoácidos... vai sintetizando a proteína e... aí já..."

Tem mais algumas etapas?

"Ah! Sim... Nomes que eu nunca tinha visto antes... processar proteína e destinar."

Q.6 RELAÇÃO ENTRE AS DEFICIÉNCIAS COM PROTEÍNAS

\section{* Questionário}

"Albinismo (falta de uma proteína)".

* Pré-entrevista

Pedi que explicasse a relação do Albinismo com proteínas.

"O albinismo, pelo que me lembro, a minha professora de Biologia falou a algumas semanas atrás... hehe., é a falta de uma proteína na pele do ser humano que não deixa ela adquirir o pigmento".

* Pós-entrevista

Pedi para relacionar deficiências relacionadas a proteínas... pode ser local, tipo na pele.

"Que tem a melanina".

O que pode acontecer a pele, se não for produzido melanina?

"Acho que com a melanina, com o tempo a pele ia clareando... mas é um processo demorado né".

Com relação ao processo de metabolismo das proteínas também não

apresentou dificuldade, uma vez que não somente demonstrou apropriação do 
conceito envolvido, mencionando "quebra" da proteína em aminoácidos, como conseguiu aplicá-lo a outro contexto, como no caso da ingestão de proteínas através da alimentação "para ter aminoácidos para sintetizarmos as nossas proteínas".

A análise da $Q .5$, com respeito à analogia proposta e ao resumo do processo de síntese protéica, nos mostrou um fato curioso. O aluno entendeu a analogia, conseguiu transpor todos os eventos e recursos necessários do preparo do bolo ao contexto celular, relacionando-os ao processo de síntese de uma proteína. Porém, ao tentar resumir todo o processo de síntese, apresentou dificuldade, ou seja, o problema não estava no significado de cada elemento presente no processo e sim na relação entre esses elementos para a construção do conceito envolvido na síntese protéica. Descrevendo o processo de síntese, o aluno remetia sempre às etapas do jogo. Ao declarar "polimerase!! Só tinha visto aquilo no jogo, nunca tinha visto antes" e "nomes que eu nunca tinha visto antes... processar proteína e destinar", nos mostra que o jogo proporcionou uma ampliação de conceitos em relação ao processo de síntese de proteína como um todo, desde seus precursores até procedimentos pós-síntese.

O aluno Junior (tab. 4.9), ao responder que proteína corresponde a uma “cadeia de aminoácidos" (Q.1b) e ter declarado na pré-entrevista que não se lembrava o que era uma proteína, somente que ela era formada de aminoácidos, pareceu ter apenas se apropriado desse conceito, porém sem compreendê-lo totalmente. Isso se refletiu na sua definição das funções das proteínas (Q.3a), em que além de afirmar que era “... para criarmos massa muscular e dar energia”, na pré-entrevista declarou que não sabia se "proteína era gordura", ou "digeria gordura". 
Tabela 4.9 - Aluno Junior (Educativa): Respostas ao questionário diagnóstico e trechos das pré e pós-entrevistas.

\section{Q.1b O QUE É UMA PROTEÍNA?}

* Questionário

"Cadeia de aminoácidos".

* Pré-entrevista

Perguntei se uma proteína era definida somente por ter uma cadeia de aminoácidos

"É, eu acho que sim, porque eu não lembro o que é uma proteína. Só lembro que ela é formada por aminoácidos... é o que eu lembro".

Perguntei se ele se lembrava de alguma função

"Não. Mais ou menos... lá no vaso, no vaso, no fundo... não lembro".

* Pós-entrevista

Não consta

Q2b. ONDE PODEMOS ENCONTRAR PROTEÍNAS, ALÉM DOS ALIMENTOS?

* Questionário

"Em nossos músculos e em outras estruturas das plantas como o tecido que as constitui: celulose".

\section{* Pré-entrevista}

Pedi para dizer onde podemos encontrar proteínas em nosso organismo ou de outros seres

"Então, eu não sei, mas eu pensei assim que ela ajuda na formação dos músculos e dos tecidos.

Eu coloquei que eu acho que também na planta, ela é que forma os tecidos da planta. É o que eu acho... a celulose... não sei, posso estar equivocado".

\section{* Pós-entrevista}

Baseado no jogo, onde encontramos proteínas

"A proteína a gente acha no nosso organismo, nas células. Elas são formadas nas células. Sim, o jogo me ajudou a lembrar mais, porque eu lembro que na hora que você fez aquela primeira entrevista eu falei tudo errado, depois, ali no jogo eu lembrei. Mas eu já esqueci tudo".

Pedi que se lembrasse da proteína que ele formou

"Eu não lembro a minha, não sei se era adrenalina... não sei".

Q3a. QUAL O GRANDE PAPEL DAS PROTEÍNAS?

* Questionário

"Para criarmos massa muscular e dar energia e seu grande papel é...."(o aluno não completou)".

* Pré-entrevista

Pedi que completasse o que havia comecado a responder no questionário.

"E eu não coloquei. Eu acho que o grande papel é ajudar na formação do músculo, mas eu não lembro, proteína é gordura ou digere gordura?... tem alguma coisa que digere gordura que eu não lembro..."

\section{* Pós-entrevista}

Relembrei algumas proteínas vistas no jogo e pedi que associasse uma função a elas

Proteína da pele:

"Estrutural?"

Adrenalina:

"Daí é energia, porque ela vai ser usada pelo corpo para produzir um tipo de energia, que seria a adrenalina..."

Rodopsina:

"Ela atua no músculo do olho".

"Não sei..."

\section{Q.4 COMO AS PROTEÍNAS SÃO ABSORVIDAS POR NOSSO ORGANISMO?}

* Questionário

"Por meio de sua quebra e absorção das células e tecidos".

* Pré-entrevista

Pedi um esclarecimento

"Eu acho que os aminoácidos que compõe a proteína são quebrados em partículas menores e as células conseguem absorver."

Quando questionado sobre o que realmente é quebrado se as proteínas ou os aminoácidos

"Não, a proteína não é composta por uma cadeia de aminoácidos? Então quando ela é quebrada é quebrada em aminoácidos e eles são absorvidos pela célula".

Para que vão servir

"Não sei!" 
Continuação

* Pós-entrevista

O que a célula precisa para sintetizar proteínas?

"Aminoácidos"

Por que precisamos ingerir proteínas?

"Pra fornecer energia para o nosso corpo".

No processo de digestão o que acontece com as proteínas?

"Vão ser quebradas"

Quebradas em que?

"Em aminoácidos"

Você acredita que esses aminoácidos vão ser utilizados pelas células na síntese de novas proteínas?

"É... não lembro!"

Q.5 AS CÉLULAS SÃO CAPAZES DE SINTETIZAR PROTEÍNAS?

* Questionário

a. "Sim, por meio dos ribossomos, DNA ribossômico e aminoácidos."

b. Analogia

Gaveta
Livro de receitas
Receita
Ingredientes

\begin{tabular}{cc}
\hline Questionário & Pré-entrevista \\
\hline Célula & Núcleo \\
Núcleo & DNA \\
RNA ribossômico & RNAr, RNAt e ribossomo \\
Aminoácidos & OK \\
\hline
\end{tabular}

\section{Pós-entrevista}

Resumo das etapas do processo de síntese protéica

"Tem o núcleo, aí tem o DNA, ele se divide e vão os... agora esqueci os nomes".

Se divide?

"Ele se abre, daí vem o... não sei o nome daquela outra fita que vai se combinar. Daí essa fita sai e vai no ribossomo..."

Ele sai de onde?

"Do núcleo da célula e vai no ribossomo da célula, onde vem... não lembro direito... acho que daí vem os aminoácidos, formando uma proteína ali no ribossomo, de acordo com a fita lá..."

\section{Q.6 RELAÇÃO ENTRE AS DEFICIÊNCIAS COM PROTEÍNAS}

\section{* Questionário}

"Anemia - falta de proteína no sangue".

\section{* Pré-entrevista}

Pedi para relacionar deficiências relacionadas a proteínas.

"Eu acho a falta de proteína, eu acho que o ferro é uma proteína, não sei, devo estar enganado, mas a falta de proteína no sangue causa anemia".

"Ah! Polidactilia é uma doença causada pela falta de proteína também. Acho que algumas doenças genéticas também, só que eu não sei algum nome, acho que Nelzaimer, acho que é.... Tem algumas doenças, que depois que você saiu da sala, a Adriana falou de algumas doenças só que eu lembro da polidactilia, que é uma que a gente está estudando".

\section{* Pós-entrevista}

De acordo com o jogo, pedi para relacionar algumas deficiências a proteínas.

No caso da falta da adrenalina em uma situação de perigo

"Você não saberá reagir".

Pedi para relacionar outras

"Se faltar alguma proteína do seu olho, seu olho não reage de acordo com a luminosidade. Então a luz pode queimar sua retina".

No caso da pele, o que acontecerá se faltar melanina

"Então se você fizer um corte, sua pele não... seu sangue não... não vai cicatrizar".

No que se refere às estruturas compostas por proteínas (Q.2b), houve uma ampliação de conhecimento, pois no questionário Junior respondeu que as proteínas eram encontradas preferencialmente nos músculos, sendo isso reforçado na pré- 
entrevista. No entanto, na pós-entrevista declarou que as proteínas "são encontradas nas células... são formadas nas células".

Embora Junior tenha mencionado "quebra" das proteínas em aminoácidos ao descrever o processo de metabolismo das proteínas durante a digestão (Q.4), quando questionado na pós-entrevista a respeito da necessidade de ingestão de proteínas, para ele prevaleceu a concepção de que é "prá fornecer energia para o nosso corpo".

Ao relatar de forma geral o processo de síntese protéica $(\mathrm{Q} .5 \mathrm{a})$, o aluno Junior demonstrou certa dificuldade. Mas embora seu discurso pareça simplista, podemos perceber que ele compreende parte do processo e seus elementos principais. Isso pode ser percebido também ao analisarmos a forma como ele transpôs corretamente a analogia do bolo com o processo de síntese na célula. Já no pós-entrevista, percebemos, pela fala do aluno, uma ampliação da sua compreensão quanto às etapas do processo de síntese. Segundo Junior, o processo inicia no "núcleo da célula e vai no ribossomo da célula, onde vem... não lembro direito... acho que daí vem os aminoácidos, formando uma proteína ali no ribossomo, de acordo com a fita lá...”. O fato de o aluno não ter se apropriado de termos científicos como 'transcrição', 'tradução', RNA mensageiro e etc., não quer dizer que não tenha assimilado o conceito implícito neles. Portanto, quando o aluno menciona, por exemplo, que uma proteína se forma no ribossomo "de acordo com a fita lá”, podemos inferir que o aluno se referia ao RNA mensageiro.

De um modo geral podemos perceber nas falas da aluna Kátia (tab. 4.10) uma grande dificuldade em se expressar, em lidar com os conceitos e na maior parte do tempo recorrendo a concepções alternativas. Para ela as proteínas "existem em alguns alimentos e nosso corpo também produz". É como se o corpo produzisse, 
segundo ela, algumas proteínas e as outras proteínas importantes para o organismo tivéssemos que repor com a alimentação. Quando pedido para ela descrever o papel das proteínas, afirmou no questionário: "Existe o DNA que produz o RNA, tem as bases e elas produzem os aminoácidos que produz proteínas. Elas são importantes, por exemplo, a falta de proteínas da pele”. Ao tentar esclarecer sua resposta na préentrevista, apresentou respostas muito confusas do tipo "tem aqueles três RNAs, o "m" e o "t", daí eles fazem a parte deles sabe, tipo pega um e vai colocando, encaixa sabe nas bases assim, aquelas bases $A, T, C, G$ ", ou se referindo ao momento em que a proteína é formada como "acho que no momento que encaixa as bases... não tenho certeza, quando está tudo tipo, pegou, ta tudo bonitinho, o RNA ta montado bonitinho com as bases tal...".

Tabela 4.10 - Aluna Kátia (Educativa): Respostas ao questionário diagnóstico e trechos das pré e pós-entrevistas.

\section{Q.1b O QUE É UMA PROTEÍNA?}

\section{* Questionário}

"Proteína existe em alguns alimentos e nosso corpo também produz. Com o RNA nós produzimos proteína, por exemplo: a proteína da pele. Se a pessoa tem pouca dessa proteína ela é albina, que tem já tem mais dessa proteína".

\section{* Pré-entrevista}

Pedi que explicasse, para eu poder entender melhor o que escreveu no questionário

"Ah! Eu acho, tipo... nosso corpo com o RNA produz... tem o RNA mensageiro, transportador e o "r"... ribossômico. Daí ele produz, sabe... daí, tipo, por exemplo coloquei a proteína da pele aí... coloquei que se você tem mais cor assim entre aspas, você produz mais essa proteína, se não tivesse você não produz tanto. Quem é albino não produz quase nada assim, sabe, dessa proteína".

\section{* Pós-entrevista}

\section{Não consta}

\section{Q2b. ONDE PODEMOS ENCONTRAR PROTEÍNAS, ALÉM DOS ALIMENTOS?}

\section{* Questionário}

"Nossa pele, nossas células - essas células podem dar a você a cor do cabelo, olho".

\section{* Pré-entrevista}

Pedi que explicasse um pouco mais o que escreveu

"É que a célula... não sei se está certa, mas sei lá, é que pela célula você produz RNA né... bom, tem o DNA lá dentro da célula bonitinho, aí faz o RNA tal e tipo, na nossa pele tem proteína, acho que por exemplo, a mesma coisa do albino... eu peguei essa pra fazer a coisa inteira".

Você disse no cabelo

Então do cabelo você pode... não sei se é proteína mesmo assim sabe, mas acho que tem mais a ver com o DNA. Sei lá... pra ver se é escuro, talvez tenha uma proteína que te dá a cor do seu cabelo assim, ser escuro ou loiro... sei lá... com o olho é a mesma coisa.

\section{* Pós-entrevista}

Pedi que, baseada no jogo, me falasse onde podemos encontrar proteínas. Mas mesmo fazendo algumas intervenções no sentido de relembra-la não conseguiu. 
Q3a. QUAL O GRANDE PAPEL DAS PROTEÍNAS?

Continuação

\section{* Questionário}

"Existe o DNA que produz o RNA, tem as bases e elas produzem os aminoácidos que produz proteínas. Elas são importantes, por exemplo, a falta de proteínas da pele".

* Pré-entrevista

Pedi que tentasse lembrar das etapas da síntese

"Seu corpo tem DNA tal, você produz... Ao tem o RNA, que pelo DNA você produz o RNA, aí tem aqueles três RNAs, o "m" e o "t", daí eles fazem a parte deles sabe, tipo pega um e vai colocando, encaixa sabe nas bases assim, aquelas bases A, T, C, G".

Em que momento a proteína se forma

"Acho que no momento que encaixa as bases... não tenho certeza, quando está tudo tipo, pegou, ta tudo bonitinho, o RNA ta montado bonitinho com as bases tal... eu não sei, acho que é isso".

* Pós-entrevista

Também não conseguiu discorrer sobre o assunto

Q.4 COMO AS PROTEÍNAS SÃO ABSORVIDAS POR NOSSO ORGANISMO?

* Questionário

"Os alimentos são ingeridos e depois vão para o intestino e são excretadas pela urina. Algumas proteínas ficam no nosso estômago".

\section{* Pré-entrevista}

Pedi que explicasse como as proteínas vão ser absorvidas

"Assim eu não sei... boa pergunta, sei lá deve ser alguma coisa no nosso corpo pega um pouco e sei lá tipo, eu não sei o que, mas nosso corpo tipo guarda... sei lá, quando a gente come, alguns saem e outros ficam sabe, porque é bom para o nosso organismo... deve ser a mesma coisa assim".

Pedi que explicasse o que acontecia com os alimentos na digestão

"Mastiga ele, fica pequeno..."

Perguntei se ela achava que nesse processo a proteína ia ser quebrada ou não.

"Vai ser quebrada assim sabe... não sei, não tenho a mínima idéia. Acho que ela vai ser quebrada... algumas partes podem sair outras ficam assim ou até pode tudo sair, daí você vai ingerindo mais assim, mas acho que não, um pouco fica e um pouco sai".

\section{* Pós-entrevista}

Do que a proteína é composta?

"Aminoácidos".

Se as proteínas são formadas de aminoácidos, por que ingerimos proteínas?

"Porque talvez não é suficiente, ou é perdido alguma coisa".

\section{Q.5 AS CÉLULAS SÃO CAPAZES DE SINTETIZAR PROTEÍNAS?}

\section{* Questionário}

a. "Sim, pelas nossas células produz o RNA e o RNA produz as necessárias para a nossa vida".

b. Analogia

\begin{tabular}{ccc} 
& Questionário & Pré-entrevista \\
\cline { 2 - 3 } Gaveta & Célula & Núcleo \\
Livro de receitas & DNA & OK \\
Receita & RNA & RNA mensageiro \\
Ingredientes & As bases e aminoácidos & OK
\end{tabular}

\section{Pós-entrevista}

Resumo das etapas do processo de síntese protéica

Comeca aonde?

Não conseguia se lembrar nem da seqüência e fazia confusão com as estruturas.

Q.6 RELAÇÃO ENTRE AS DEFICIÊNCIAS COM PROTEÍNAS

\section{* Questionário}

"A falta de cor na pele - pessoa albina e alguém com anemia".

* Pré-entrevista

Porque Anemia está relacionada

"Sei lá, talvez tipo, se você não ingere tanto alimento que tenha ferro, daí você fica feio..."

* Pós-entrevista

Pedi para lembrar das cartas objetivo e relacionar proteína a deficências

"Só lembro da adrenalina que não liberar... sei lá!" 
Com relação ao metabolismo das proteínas durante o processo de digestão, apresentou respostas como: "os alimentos são ingeridos e depois vão para o intestino e são excretadas pela urina. Algumas proteínas ficam no nosso estômago" ou "acho que ela vai ser quebrada... algumas partes podem sair outras ficam assim ou até pode tudo sair, daí você vai ingerindo mais assim, mas acho que não, um pouco fica e um pouco sai". Até mesmo na pós-entrevista, quando questionada por que precisamos ingerir proteínas, apresentou uma resposta pautada em concepções do tipo "porque talvez não é suficiente, ou é perdido alguma coisa".

Com relação ao processo de síntese protéica, não conseguiu lembrar-se de nenhuma etapa do jogo.

O aluno Guto (tab. 4.11), de uma forma geral, mostrou-se seguro com relação aos conceitos envolvidos e não apresentou dificuldades em articulá-los ou aplicá-los em outros contextos, como observado, por exemplo, na sua explicação sobre o processo de digestão. Define proteínas como uma "cadeia de aminoácidos", localiza a sua presença na membrana plasmática, pele e cabelo, e depois acrescenta que todas as células do nosso organismo são constituídas de proteínas. Guto acredita que as proteínas desempenham diversas funções no nosso organismo, citando o exemplo da melanina que "protege nossa pele contra os raios do sol". No processo de digestão as proteínas são quebradas em aminoácidos que serão depois reaproveitados pelas células na síntese de novas proteínas.

Tabela 4.11 - Aluno Guto (Educativa): Respostas ao questionário diagnóstico e trechos das pré e pós-entrevistas.

\section{Q.1b O QUE É UMA PROTEÍNA?}

* Questionário

"A proteína é uma cadeia de aminoácidos. Elas realizam diversas funções nos seres vivos, por isso são importantíssimas para a vida".

* Pré-entrevista

Como estava bastante claro, não tinha o que acrescentar

* Pós-entrevista

Não consta 
Q2b. ONDE PODEMOS ENCONTRAR PROTEÍNAS, ALÉM DOS ALIMENTOS?

Continuação

\section{* Questionário}

"A membrana plasmática das células contém proteínas, por exemplo. Por isso a pele também contém. Ela contém a melanina que determina sua coloração".

\section{* Pré-entrevista}

Pedi que se lembrasse de mais algum exemplo

"Acho que o cabelo... é constituído de proteína. O que mais?... acho que todas as células tem proteínas, todas as células do nosso organismo tem... eu acredito".

\section{* Pós-entrevista}

Onde podemos encontrar proteínas em nosso organismo e se o jogo ajudou

"Quase tudo!"

"Ajudou a relembrar... é, algumas coisas eu já sabia, mas na verdade tem alguns detalhes que eu não sabia".

\section{Q3a. QUAL O GRANDE PAPEL DAS PROTEÍNAS?}

\section{* Questionário}

"Precisamos de proteínas, pois elas desempenham diversos papéis, têm diversas funções no nosso organismo. Um exemplo é a membrana plasmática".

\section{* Pré-entrevista}

Perguntei se podia citar pelo menos uma função ou papel?

"Ah! Papel?... deixa eu pensar... bom, a melanina serve para proteger a pele contra os raios do sol... silêncio... eu não lembro".

\section{* Pós-entrevista}

Dependendo de onde estiverem qual o grande papel?

"Aaaa... o grande papel?... acho que tem várias funções..."

Por exemplo a adrenalina

"Nos deixar... mais alerta!"

Q.4 COMO AS PROTEÍNAS SÃO ABSORVIDAS POR NOSSO ORGANISMO?

\section{* Questionário}

"Os alimentos contém proteínas formadas de diversos aminoácidos. Essas proteínas são 'quebrados' através da digestão, então os aminoácidos se separam novamente. As nossas células sintetizam novas proteínas com esses aminoácidos através do RNA ribossômico".

\section{* Pré-entrevista}

Para formar novas proteínas as células vão utilizar esses aminoácidos?

"Sim, ela vai utilizar os aminoácidos que conseguimos através da alimentação e é o DNA que controla isso".

Quer dizer que nosso organismo está querendo a proteína em si ou seus aminoácidos?

"Eu acredito que são os aminoácidos... os aminoácidos mesmo".

Se ingerirmos leite por exemplo, a proteína inteira serve para o nosso organismo?

"Ela vai ser útil porque ela vai fornecer certos aminoácidos que nosso corpo produz".

\section{* Pós-entrevista}

Quais os componentes que formam uma proteína?

"Aminoácidos?... aminoácidos"

Por que precisamos ingerir proteínas?

"Porque a gente quebra para transformar em aminoácidos de novo".

\section{Q.5 AS CÉLULAS SÃO CAPAZES DE SINTETIZAR PROTEÍNAS?}

\section{* Questionário}

a. "Sim, certas estruturas da célula as sintetizam."

b. Analogia

$$
\begin{gathered}
\text { Gaveta } \\
\text { Livro de receitas } \\
\text { Receita } \\
\text { Ingredientes }
\end{gathered}
$$

\begin{tabular}{cc}
\hline Questionário & Pré-entrevista \\
\hline Núcleo & OK \\
DNA & OK \\
RNAm & RNAm \\
Aminoácidos & OK \\
\hline
\end{tabular}

\section{Pós-entrevista}

Resumo das etapas do processo de síntese protéica

"Bom, tem o DNA e a partir do DNA que forma o RNA. Então o RNA... a cadeia do RNA que determina quais aminoácidos vão ser unidos. Então os RNAs transportadores é que vão levar os aminoácidos em direção ao RNA mensageiro. Então a cada trinca... é, não conheço mais ninguém 
que participa".

Quem faz a leitura do RNAm?

"É o ribossomo".

Q.6 RELAÇÃO ENTRE AS DEFICIÊNCIAS COM PROTEÍNAS

* Questionário

"Anemia - falta de proteína no sangue".

* Pré-entrevista

Não foi perguntado

* Pós-entrevista

Não foi perguntado

$\mathrm{Na}$ pós-entrevista, o aluno descreve corretamente as etapas da síntese protéica (Q.5), porém não há elementos na sua fala que podem indicar com clareza que esse conhecimento e/ou relações estabelecidas tenham sido incorporados após o jogo. Na descrição do processo de síntese, comenta "Bom, tem o DNA e a partir do DNA que forma o RNA. Então o RNA... a cadeia do RNA que determina quais aminoácidos vão ser unidos. Então os RNAs transportadores é que vão levar os aminoácidos em direção ao RNA mensageiro. Então a cada trinca... é, não conheço mais ninguém que participa". E ao perguntar que fazia a leitura do RNAm - "é o ribossomo".

Para o aluno Breno (tab. 4.12) uma proteína é uma "cadeia de aminoácido (ou sei lá) que pode ser metabolizada pelo organismo e ajudar na formação da musculatura" (Q.1b), portanto uma definição baseada em sua estrutura primária. Relata também o papel ou função da proteína na formação da musculatura, sendo confirmada nas Q.2b e Q.3a, relativas ao questionário diagnóstico e "os tecidos" na pré-entrevista (Q.2b). No entanto podemos perceber na pós-entrevista uma ampliação dessa visão, ao afirmar que "tem proteína dentro das células", portanto não restringe a uma única estrutura. Com respeito às funções das proteínas, lembrou da sua carta-objetivo e citou a importância da 'adrenalina' para o organismo em situações de perigo que exige 'reflexo', tomada de decisão. 
Tabela 4.12 - Aluno Breno (Educativa): Respostas ao questionário diagnóstico e trechos das pré e pós-entrevistas.

\author{
Q.1b O QUE É UMA PROTEÍNA? \\ * Questionário \\ "Cadeia de aminoácido (ou sei lá) que pode ser metabolizado pelo organismo e ajudar na formação \\ da musculatura".
}

* Pré-entrevista

As proteínas se diferem só por possuírem aminoácidos?

"Basicamente isso, tem outras funções, mas ele é isso".

\title{
* Pós-entrevista
}

Não consta

Q2b. ONDE PODEMOS ENCONTRAR PROTEÍNAS, ALÉM DOS ALIMENTOS?

\section{* Questionário}

"Músculos".

\section{* Pré-entrevista}

Nossas proteínas estão concentradas nos músculos?

"É, nos tecidos, músculos e coisa do gênero".

Teria outro lugar? Por exemplo, sangue...

"Deve ter, não dá para dizer que não tem, $0 \%$ assim, mas deve ter assim... 10\%".

\section{* Pós-entrevista}

Baseado no jogo, onde podemos encontrar proteínas

"Tem proteína dentro da célula... naquela..."

Você se lembra da proteína que formou?

"Só sei que era... nem me lembro da coisa direito... calma aí. Era dentro da célula... ajudou a aumentar né, pois eu não sabia quais eram as etapas, pra onde iria, nada. Começava dentro do núcleo, saia e ia para o ribossomo, basicamente era isso que tinha".

\section{Q3a. QUAL O GRANDE PAPEL DAS PROTEÍNAS?}

\section{* Questionário}

"Nós usamos proteínas dos outros para formar musculatura e nosso para criar RNA e DNA".

\section{* Pré-entrevista}

Me explique esses dois tipos de proteínas?

"Eu acho que tipo, a proteína que a gente recebe estão numa ordem diferente e a gente precisa quebrar ela pra poder usar no nosso organismo. O nosso DNA e RNA, eles são cadeias de proteínas, eu acho, não sei... tenho quase certeza que é. E daí a gente fez para poder trazer os pés pra frente... e ter mais saúde também".

Você acredita que nossas células não produzem todas as proteínas?

"Não, eles podem produzir proteínas assim... proteína por proteína, mas tipo, a gente faz uma cadeia de aminoácidos assim diferente, do que dos outros. É que tipo, a proteína deles é igual a nosso, só que tipo, a cadeia deles é diferente da nossa. Porque proteína é uma cadeia de aminoácido e a cadeia deles é diferente da nossa e a gente não consegue fazer igual a deles, a nossa é da espécie humana, que carrega as nossas características".

\section{* Pós-entrevista}

Lembrando das proteínas que tinham no jogo, qual o grande papel delas?

"Ela ajuda nas funções do organismo. Tem a adrenalina, que ela ajuda nas funções do organismo, basicamente coisas intuitivas. Não emocionais, nem nada, mas.... A adrenalina por exemplo, ela solta no seu cérebro quando você tem alguma coisa tipo, rápido sabe, que tem algum perigo. Porque tendo mais adrenalina, tem mais gás assim, você consegue se livrar da situação".

\section{Q.4 COMO AS PROTEÍNAS SÃO ABSORVIDAS POR NOSSO ORGANISMO?}

\section{* Questionário}

"Ela quebra a cadeia de aminoácidos e as absorve".

\section{* Pré-entrevista}

Pedi para explicar um pouquinho melhor

"Quando a gente come carne ou coisa que a gente possa absorver proteínas, a gente come, só que tipo lá no estômago ou sei lá no... depois do estômago, não sei, a gente tenta quebrar um pouco essas proteínas, elas são muito grandes para a gente absorver. Então é assim que a gente metaboliza as proteínas né, a gente quebra a cadeia de aminoácidos pra transformar em menor tamanho pra a gente poder absorver". 
Continuação

* Pós-entrevista

Do que a proteína é composta?

"Ela é formada por aminoácidos... cadeias de nitrogênios lá".

Se as proteínas são formadas de aminoácidos, por que ingerimos proteínas?

"Pra conseguir os... pra a gente quebrar, pra formar aminoácidos, depois quebrar mais ainda pra poder usar... reformular de novo, tipo... é que nem lego assim, você quebra e faz outro..."

\section{Q.5 AS CÉLULAS SÃO CAPAZES DE SINTETIZAR PROTEÍNAS?}

* Questionário

a. "Eles fazem DNA, que é uma cadeia de proteína".

b. Analogia

Gaveta

Livro de receitas

Receita

Ingredientes
Questionário

Núcleo

DNA

O que a gente é

Nucleotídeos
Pré-entrevista

OK

OK

Tem a ver com as

características

OK

* Pós-entrevista

Resumo das etapas do processo de síntese protéica

Comeca aonde?

"No DNA. Quebra na metade, faz o RNA mensageiro ligando um com o outro... sai da carioteca, vai para o ribossomo... daí faz os RNAs transportadores. Daí esses RNAs vão e... daí as célula solta e ta pronto".

Q.6 RELAÇÃO ENTRE AS DEFICIÊNCIAS COM PROTEÍNAS

* Questionário

"Anemia".

* Pré-entrevista

Porque Anemia está relacionada

"Porque... esqueci o nome... acho que é hemácias, que tem lá no sangue. Anemia é quando a gente tem pouco glóbulos vermelhos. Então as hemácias são feitas de proteínas né, então ela é uma doença relacionada a proteínas, a gente precisa fazer as hemácias... é isso".

\section{* Pós-entrevista}

Pedi para relacionar a sua carta-objetivo (Adrenalina) com alguma deficiência decorrente

"Você teria uma reação mais lenta. Se você não tivesse bom reflexo assim, você teria... você iria se 'ferrar' mesmo. Daí você iria ou ficar parado assim, em estado de choque, ou também você iria tomar uma atitude, só que mais lenta.

E também a melanina lá que a gente forma, que a gente faz quando o sol bate. Daí também se a gente não tiver a gente pode pegar câncer".

Ao descrever como as proteínas são absorvidas pelo nosso organismo (Q.4), menciona "quebra da cadeia de aminoácidos". Curiosamente o aluno descreve, na pré-entrevista, que "quebra a cadeia de aminoácidos pra transformar em menor tamanho pra a gente poder absorver", mas não associa essas 'partes de menor tamanho' aos aminoácidos. Para ele 'cadeia de aminoácidos' é sinônimo de 'proteínas'. No entanto, podemos perceber com a pós-entrevista que o Breno não somente mencionou a 'quebra' das proteínas no processo de digestão como mencionou a quebra "pra formar aminoácidos"e depois reutilizá-los "que nem lego". 
Na descrição do processo de síntese protéica, mesmo de forma simplista, o aluno mencionou onde ocorria cada etapa e que estrutura estava envolvida, fazendo alusão as etapas do jogo: "no DNA (onde começa). Quebra na metade, faz o RNA mensageiro ligando um com o outro... sai da carioteca (alusão a etapa 2 do jogo, “atravessar a carioteca"), vai para o ribossomo (etapa 3, em que os alunos pegavam sua fita de RNAm e 'transportavam' até a região do ribossomo, no tabuleiro)... daí faz os RNAs transportadores. Daí esses RNAs vão e... daí as célula solta e ta pronto". Com relação às doenças podemos perceber um aumento no seu repertório, pois no questionário havia apenas associado anemia e já na pós-entrevista lembrouse das situações-problema envolvendo as proteínas 'adrenalina' e 'melanina'.

De forma geral, levando-se em consideração que uma parcela dos alunos já havia estudado o tema proteínas na escola (conforme questão 7 da tabela 4.2), pudemos notar em seus discursos a presença de muitos termos e definições próprias da linguagem científica da área. No entanto, a maior dificuldade apresentada pelos alunos estava na aplicação desses termos e definições em outros contextos. Somente o fato de se apropriar de uma palavra não garante a apropriação do conceito embutido nela (PEDRANCINI, 2007).

Por exemplo, ao compararmos as diferentes definições de proteínas apresentadas pelos alunos, tais como "uma molécula formada por um conjunto de aminoácidos" (Maurício, EEAG); "uma estrutura molecular composta de aminoácidos" (Paulo, Educativa); "um conjunto de aminoácidos" (Michael, EEAG); "cadeia de aminoácidos" (Junior, Guto e Breno, Educativa), podemos supor que as mesmas foram concebidas baseadas em um atributo, 'possuírem aminoácidos como unidade monomérica'. Todos esses alunos citados, ao aplicarem esse conceito ao processo de digestão e absorção de proteínas por meio da alimentação, foram 
unânimes em relacionar digestão a um processo de 'quebra'. Somente os alunos Paulo e Guto afirmaram, entre o questionário e a pré-entrevista, que as proteínas eram 'quebradas em aminoácidos' e estes 'são absorvidos pelas células para a síntese de novas proteínas'. Os demais tiveram dificuldade em aplicar o conceito e recorreram a formas elementares de pensamento, como "mastiga ele, fica pequeno..." (Kátia, Educativa), "no processo de digestão os alimentos são quebrados em micro partículas” (Maurício, EEAG), “as proteínas são quebradas pelas enzimas, assim ficam menores e podem ser absorvidas” (Michael, EEAG) ou "o suco gástrico do estômago quebra a proteína em vários pedaços” (James, EEAG). Na literatura, esse tipo de concepção foi encontrado entre alunos do ensino fundamental, com idade média de 10 anos, ao tentarem definir o que acontece com os alimentos após serem digeridos (CARVALHO, 2004; CAKICI, 2005).

De acordo com Vygotsky (1991a), isso se deve ao fato de os adolescentes, mesmo após aprenderem a formar conceitos, não abandonam as formas mais elementares de pensamento, idéia também defendida por Mortimer (1995), em que a construção do conhecimento não se dá através da ruptura entre as formas de pensar, e sim através da tomada de consciência de cada uma delas e dos argumentos que justificam o uso de uma ou de outra em determinados contextos. Em outras palavras, para Vygotsky a adolescência é marcada pela transição entre duas fases de pensamento, o chamado 'pensamento por complexos', em que as relações atribuídas aos elementos podem ser tão diversas quanto às relações que realmente existem entre eles, e a fase do 'pensamento por conceitos', em que as relações baseiam-se em atributos. Sendo que, em alguns casos, o pensamento por 'complexos' predomina em relação aos 'conceitos'. A maior dificuldade encontrada 
pelos adolescentes, segundo Vygotsky, não está na formulação dos conceitos, mas em sua definição e aplicação.

Apesar dessa predominância de pensamentos baseados em complexos, ou seja, apesar de em muitas construções dos alunos prevalecerem formas primitivas ou simplistas de pensamento, devemos destacar que a interação dos mesmos com o jogo, por seu caráter simbólico e lúdico, contribuiu para o desenvolvimento cognitivo dos alunos, como observado nas pós-entrevistas. Dessa forma pudemos perceber a evolução de alguns modelos conceituais, discutidos com mais detalhes a seguir.

\subsubsection{Análise das interações ocorridas durante o jogo}

Transcorridos cerca de 1 mês após a entrevista com os alunos selecionados, os mesmos foram convidados a participarem da $2^{a}$ etapa do projeto, a aplicação do jogo. Na ocasião o mestrando - aqui identificado pelo seu próprio nome (Julio) atuou tanto como mediador quanto jogador, participando ativamente do jogo com os alunos. Com a mesma justificativa explicitada na seção 4.2.3, os trechos analisados a seguir referem-se à aplicação do jogo com os alunos selecionados das turmas do $2^{\circ} \mathrm{G}$ do Álvaro Guião e do 2B da Educativa.

Analisando as transcrições do áudio das filmagens, procuramos identificar possíveis interações (mediador-aluno e aluno-aluno) ocorridas durante o jogo e a influência das mesmas no processo de ensino-aprendizagem, em termos de evoluções conceituais percebidas nos discursos dos alunos durante a pós-entrevista 
e à luz do referencial de Vygotsky. Optou-se então por analisar os principais trechos (chamados de seqüências) das transcrições das duas turmas envolvidas, em que percebemos maior riqueza de tais interações. Estas transcrições podem ser vistas integralmente nos apêndices $\mathrm{G}$ e $\mathrm{H}$.

Vale ressaltar que, para a turma do Álvaro Guião que era composta por 3 alunos, optamos por jogar individualmente (ao invés de duplas) de modo a explorar mais exemplos de proteínas. Para a turma da Educativa, que continha 6 participantes, o jogo foi organizado em duplas e somente o mestrando jogou individualmente.

Antes de iniciar as partidas com as turmas, o mestrando (caracterizado nas seqüências com um grifo em seu nome) primeiramente apresentou o jogo aos alunos, começando pelos seus componentes e em seguida explicando as regras. Como as regras do jogo correspondiam, de forma simplificada, aos processos bioquímicos que levariam à síntese de uma proteína, o mestrando aproveitou para rever os conceitos envolvidos com os alunos. Portanto as interações ocorridas entre o mestrando (mediador) e os alunos foram em sua maioria de ordem conceitual, em que o mestrando ora questionava os alunos a respeito de conceitos que eles já haviam estudado, ora introduzia novos conceitos, possibilitados pelo jogo.

Na seqüência 1, vemos que o mestrando, ao questionar os alunos do $2^{\circ} \mathrm{G}$ do Álvaro Guião acerca de qual processo tratava-se a etapa 1 do jogo, ocorrida no núcleo e a qual molécula correspondia a 'fitinha' utilizada nessa etapa, procurou ajudar os alunos a associarem os elementos dos jogo, sua regras, aos conceitos anteriormente aprendidos por eles. O mesmo podemos verificar na seqüência 2 , com os alunos do $2^{\circ} \mathrm{B}$ da Educativa, em que o mestrando, ao explicar a etapa 3 do jogo correspondente ao processo de 'tradução', buscou novamente a 
correspondência entre o que os alunos estavam observando no tabuleiro do jogo (um desenho esquemático do ribossomo), com o conceito envolvido ('leitura' do RNA mensageiro).

\section{Seqüência 1 - Álvaro Guião (Apêndice G)}

\begin{tabular}{|c|c|}
\hline$\underline{\text { JULIO }}$ & $\begin{array}{l}\text { [...] Aí, fora essa carta vocês tem essa "tirinha aqui" } \\
\text { (referindo-se a fita onde será transcrito o RNA } \\
\text { mensageiro), que a gente vai colocar aqui, pois } \\
\text { vamos começar no núcleo... e como que chama esse } \\
\text { processo que a gente vai... }\end{array}$ \\
\hline JAMES & [0:01:39] Transcrição? \\
\hline JULIO & $\begin{array}{l}\text { [0:01:42] Transcrição. Então o que vocês acham que } \\
\text { representa essa "fitinha" aqui? }\end{array}$ \\
\hline JAMES & [0:01:47] É o... \\
\hline MAURÍCIO & [0:01:48] É a cadeia de nucleotídeos do RNA. \\
\hline JAMES & [0:01:50] RNA \\
\hline JULIO & $\begin{array}{c}\text { [0:01:51] Cadeia de nucleotídeos do RNA.... (apontando para } \\
\text { os dois alunos que responderam). Qual RNA? }\end{array}$ \\
\hline MAURÍCIO & [0:01:58] RNA... no núcleo? \\
\hline JAMES & [0:01:59] RNA mensageiro? \\
\hline$\underline{\text { JULIO }}$ & $\begin{array}{l}\text { [0:02:01] RNA mensageiro. Quer dizer que a gente vai } \\
\text { começar aqui (apontando para o núcleo da célula), a } \\
\text { gente vai começar com esse primeiro processo que é } \\
\text { o de transcrição [...] }\end{array}$ \\
\hline
\end{tabular}

\section{Seqüência 2- Educativa (Apêndice $\boldsymbol{H}$ )}

JULIO [0:09:32] [...] aqui ó, seu RNA mensageiro vai começar outro processo, que é o que? Tradução, né gente? (todos acenaram com a cabeça em sinal positivo). Que é onde realmente vai ocorrer o processo de síntese de proteína. Então estão vendo esse "bichinho" aqui? (apontando para a figura do ribossomo no tabuleiro) te lembra alguma coisa?

PAULO [0:09:50] Ribossomo

JULIO [0:09:51] Ribossomo né gente? Então essa estrutura aqui se junta ao RNA mensageiro. O ribossomo vai começar a fazer o que? A leitura do RNA mensageiro, ta? E aqui vai funcionar o que? Qual outro tipo de RNA que vai ajudar o ribossomo na produção da proteína?

PAULO [0:10:11] RNA transportador? 


\begin{tabular}{|c|c|}
\hline$\underline{\text { JULIO }}$ & $\begin{array}{l}\text { [0:10:12] RNA transportador. Qual a função do RNA } \\
\text { Transportador? }\end{array}$ \\
\hline PAULO & [0:10:15] Trazer os aminoácidos. \\
\hline$\underline{\text { JULIO }}$ & [0:10:17] Trazer os aminoácidos. \\
\hline JUNIOR & $\begin{array}{l}\text { [0:10:20] Voltando-se para a KÁTIA, disse algo do tipo: Sabe } \\
\text { tudo! E ela riu. }\end{array}$ \\
\hline
\end{tabular}

Em outros momentos, no entanto, o jogo proporcionou situações inéditas aos alunos, com introdução de termos que não tinham se deparado ainda em sala de aula. Na ocasião o mestrando, como mediador e 'parceiro mais capaz', explicou seus significados e importância para o processo, bem como suas funções no contexto do jogo. Assim, podemos ver na seqüência 3, uma situação ocorrida no início da partida com a turma do Álvaro Guião, em que o mestrando explica aos alunos a importância da molécula 'RNA polimerase' no processo de síntese protéica.

Seqüência 3- Álvaro Guião (Apêndice G)

[...] Para iniciar lá o processo de transcrição, eu preciso de uma molécula que chama "RNA polimerase", ela que é responsável, depois que as fitas do DNA estão abertas, em reconhecer e encaminhar a ligação de todos os nucleotídeos.

MAURícIO [0:06:29] E ela acha onde é que está o gene?

JULIO $\quad[0: 06: 31]$ Isso!

MAURícIO [0:06:34] Ela desfaz as ligações hidrogenadas? (referindo-se as pontes de hidrogênio)

JULIO [0:06:35] Esse desfazer da hélice, quem faz é outra proteína, ela chama "helicase", mas não vem ao caso, então a gente já está partindo do pressuposto que já está aberto. Depois que o DNA se abre, a RNA polimerase reconhece a região onde vai ser sintetizado o RNA mensageiro e vai "colocar" os nucleotídeos aqui [...] Então pra começar o jogo eu preciso ter primeiro essa daqui, "RNA polimerase"

Na seqüência 4, por exemplo, temos a introdução, por parte do mestrando, da definição e função das moléculas 'RNAse' e 'Protease', bem como seus papéis no jogo. 


\begin{tabular}{|c|c|}
\hline JAMES & [0:13:54] O que é RNAse? \\
\hline JULIO & $\begin{array}{l}\text { [0:13:56] Ah, esqueci de explicar... tem duas cartinhas aí que } \\
\text { são cartinhas "coringa" vamos dizer assim, que são } \\
\text { cartas que você pode associar para "sacanear" o } \\
\text { colega. Então... }\end{array}$ \\
\hline JAMES & [0:14:11] Que ótimo!!! \\
\hline JULIO & $\begin{array}{l}\text { [0:14:12] São duas, que são duas moléculas que existem. } \\
\text { Uma delas chama "RNAse" e a outra chama } \\
\text { "Protease", sempre quando tem esse "ASE" no final, } \\
\text { em biologia, está sempre associada com tipos de } \\
\text { moléculas que podem 'quebrar' outras moléculas. } \\
\text { Então por exemplo, se é RNAse, ela vai quebrar que } \\
\text { tipo de molécula? }\end{array}$ \\
\hline JAMES & [0:14:31] RNA \\
\hline JULIO & $\begin{array}{l}\text { [0:14:32] RNA, no caso, RNA mensageiro. Então como a } \\
\text { gente vai simbolizar essa quebra aqui? Vai } \\
\text { simbolizar apagando metade do que já havia sido } \\
\text { feito, como uma forma de padronizar [...] E a } \\
\text { protease é quando já... a molécula saiu daqui } \\
\text { (núcleo), já não vale mais a RNAse, daí ela ta aqui } \\
\text { fora, quando tiver formando a proteína, colocando } \\
\text { essa seqüência de aminoácidos... [...] Aí se a pessoa } \\
\text { apresentar a carta "Protease", a pessoa apaga } \\
\text { metade do que já fez. }\end{array}$ \\
\hline
\end{tabular}

Analisaremos agora as interações do tipo aluno-aluno, que em algumas situações teve um caráter cooperativo, com um dos alunos atuando como parceiro mais capaz (VYGOTSKY, 1991a), e em outras um caráter competitivo, característico do jogo de regras (MACEDO, 1995).

As seqüências 5 e 6 , referentes ao Álvaro Guião e Educativa respectivamente, mostram situações de cooperação. Essas situações foram observadas com mais freqüência durante a primeira e a terceira etapas do jogo. $\mathrm{Na}$ primeira etapa, ditando a seqüência de nucleotídeos do DNA para que o jogador da vez pudesse inserir as bases complementares na fita correspondente ao RNA mensageiro que estava formando. Na terceira, auxiliando-o na manipulação da 
tabela de código genético, durante a tradução, fazendo correções e reformulações quando necessário.

Seqüência 5- Álvaro Guião (Apêndice G)

JULIO [0:23:02] Não, não, então você vai poder colocar 10 (nucleotídeos). Aí você vai falando pra ele aqui (pedindo para o MICHAEL ditar para o JAMES marcar na fita do RNA mensageiro).

MICHAEL $\quad[0: 23: 11] \mathrm{T}-\mathrm{A}-\mathrm{C} \ldots$ vai completando aí... T ...

JULIO $\quad$ [0:23:17] Ele vai falando a seqüência e você vai colocando a complementar...

MICHAEL $\quad[0: 23: 18] T-A-C-C-G-T-C-T \ldots 8$ não é? ... T - T. T não é U não...

JULIO $\quad$ [0:23:45] "T" é "A", só quando for "A", que é "U"... risos. Se quiser tem borracha... Agora você só descarta uma e já pode passar pro MICHAEL.

$[\ldots]$

JAMES [0:50:22] Xi MAURÍCIO, só você ta perdendo...

MICHAEL [0:50:23] Eu ajudei ele, mas ele não quis...

"AUG"... é "Met", "Lys", "Glu", "lle"... terminei.

Pega 3 aí... quanto falta pra você sair? (incentivando o MAURÍCIO a terminar o RNA mensageiro dele e sair do núcleo).

MAURícIO [0:51:58] Só os últimos... Fala aí...

MICHAEL [0:52:02] Falta só os três últimos né?

MAURÍCIO [0:52:03] É.

MICHAEL [0:52:04] "ACT". U - G - A. Você tem que ter "atravessar"...

MAURÍCIO [0:52:15] Eu tenho...

MICHAEL [0:52:16] Você tem "atravessar"? Que menino esperto...

MAURícIO [0:52:33] Deixa eu ver...

MICHAEL [0:52:34] Ribossomo...

MAURícIO [0:52:36] Tem que ser ribossomo? Então eu tenho.

MICHAEL [0:52:39] Isso! Beleza (colocando a fita do RNA mensageiro do MAURí́cIO no espaço correspondente a etapa 3).

Você descartou qual?... não, ele tem a "protease"!!... Ai, meu Pai...

$[\ldots]$

MAURÍcIO [0:53:18] A seqüência é essa daqui né? "AUG" é o que começa... "AUG" início. Aí "pula" $3 . .$. 
MICHAEL $\quad$ [0:53:40] Não, não... vai de 3 em 3... "AUG", agora "CGA"...

MAURÍCIO [0:53:45] Não vai "pulando" 3?

MICHAEL [0:53:47] Não...

MAURÍcIO [0:53:49] Você falou que ia "pulando" 3. Então como vai fazer? Codifico esses três, "pula" 3 ...

MICHAEL [0:53:59] Não!

MAURíCIO [0:54:00] É de 3 em 3, direto. "CGA", "arg"...

Na seqüência 5, podemos ver que o aluno Michael auxiliou tanto o aluno James com a primeira etapa quanto o aluno Maurício com a terceira etapa. Em ambos os casos, vemos que Michael inclusive os corrigiu. Em especial na interação do mesmo com o aluno Maurício, demonstrou ter entendido as regras e conseqüentemente o processo de tradução.

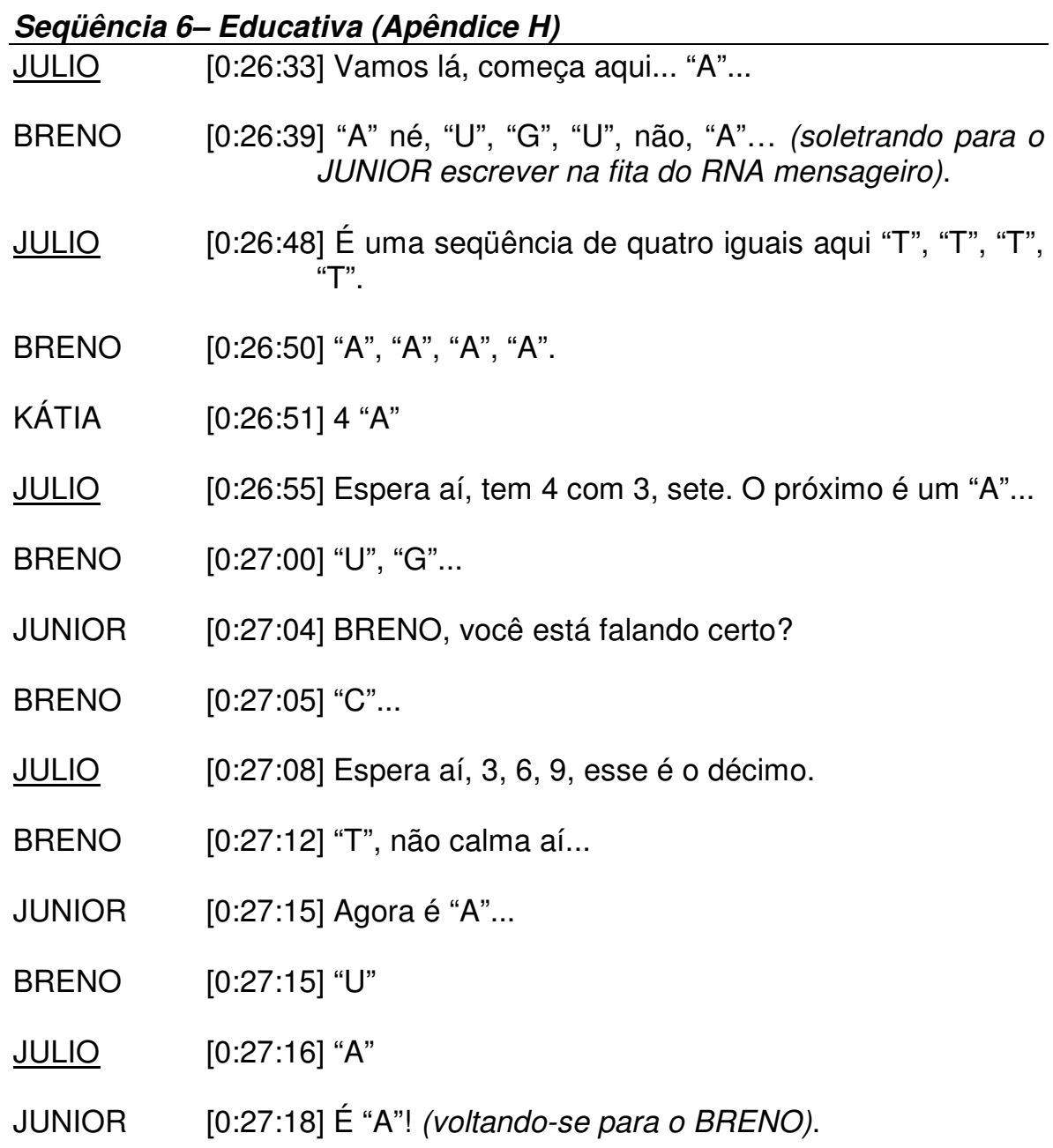




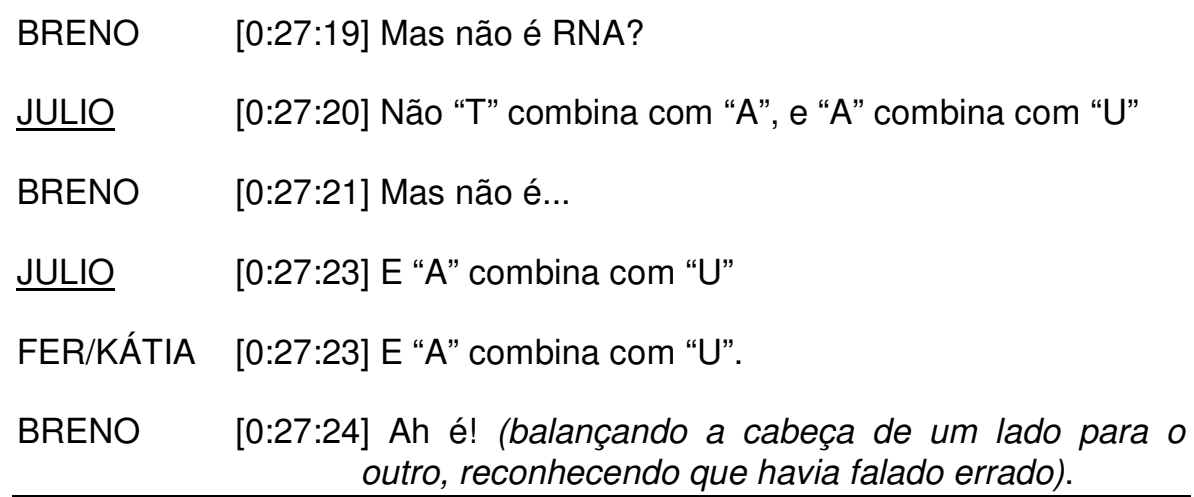

Situações de competitividade foram vistas com mais intensidade entre os alunos da Educativa, talvez pelo fato de terem jogado em dupla, como mostra a seqüência 7. Vemos que os alunos ao incorporarem as regras e entenderem que a jogada de um poderia interferir na jogada do outro, passaram a jogar estrategicamente, tomando cuidado com as cartas que poderiam descartar sem favorecer os adversários.

\section{Seqüência 7- Educativa (Apêndice H)}

JUNIOR [0:34:28] Agora ele vem e destrói tudo aqui... risos. (referindo-se ao PAULO e ao GUTO, as próximas duplas a jogarem).

PAULO [0:34:39] Vamos ver... essa aqui...

JULIO [0:34:43] Está pensando qual carta vai descartar?... e essa aqui? (apontando para uma carta que estava virada para baixo na mesa, não na mão do PAULO).

PAULO [0:34:47] Segredo!!

JUNIOR [0:34:50] Ah! Ele vai usar aquela carta... de destruir

KÁTIA [0:34:54] Ah! Não!

JUNIOR [0:34:57] A gente tem menos chance.

KÁTIA [0:34:59] Não... eu estou sozinha, não vale.

$[\ldots]$

PAULO [0:35:24] Pronto, a gente vai escolher. Aqui ó (mostrando uma carta com 8 nucleotídeos), aí a gente descarta isso aqui ó... RNA polimerase e ribossomo.

JUNIOR [0:35:35] Olha, eles sabem jogar! (voltando-se para 0 BRENO, seu parceiro). 


\begin{tabular}{|c|c|}
\hline KÁTIA & $\begin{array}{c}\text { [0:35:37] Risos, com certeza! (concordando com a afirmação } \\
\text { do JUNIOR). }\end{array}$ \\
\hline JUNIOR & [0:35:40] A gente não escolhe cartas, a gente gasta todas. \\
\hline \multicolumn{2}{|l|}{ [...] } \\
\hline$\underline{\text { JULIO }}$ & $\begin{array}{l}\text { [0:38:10] Então vocês já podem vir pra cá. (colocando-os na } \\
\text { região correspondente a etapa } 3 \text { ). }\end{array}$ \\
\hline JUNIOR & $\begin{array}{l}\text { [0:38:16] Fica, pra gente poder guardar... a gente tem duas... } \\
\text { (ele não queria descartar uma carta que serviria para } \\
\text { o grupo do PAULO). }\end{array}$ \\
\hline BRENO & [0:38:19] Não dá nada! Nós já saímos mesmo. \\
\hline$\underline{\text { JULIO }}$ & [0:38:20] Vocês tem que descartar uma. \\
\hline KÁTIA & $\begin{array}{l}\text { [0:38:21] E descarta o... de tirar... (referindo-se a carta } \\
\text { "atravessar a carioteca"). }\end{array}$ \\
\hline JUNIOR & $\begin{array}{l}\text { [0:38:27] BRENO! Eu não vou dar esse assim barato pra } \\
\text { alguém... }\end{array}$ \\
\hline$\underline{\text { JULIO }}$ & [0:38:45] Não pode ser egoísta. \\
\hline PAULO & $\begin{array}{l}\text { [0:38:56] É nóis!! (alegre por que a dupla JUNIOR e BRENO } \\
\text { acabara de descartar uma carta que servia para } \\
\text { eles). }\end{array}$ \\
\hline BRENO & $\begin{array}{l}\text { [0:39:03] Mas vocês vão ter que comprar tudo daqui. } \\
\text { (voltando-se para o PAULO, que estava prestes a } \\
\text { comprar a carta que o BRENO havia descartado, e } \\
\text { avisando que ele deveria escolher de que monte } \\
\text { deveria comprar). }\end{array}$ \\
\hline PAULO & $\begin{array}{l}\text { [0:39:04] Bem, isso não é um problema... pra quem tem duas } \\
\text { vezes "atravessar a carioteca"... risos. Porque você } \\
\text { acha que a gente ta guardando essas duas cartas? } \\
\text { Somos c... (no sentido de Somos sacanas). } \\
\text { Pode colocar } 5 \text { (nucleotídeos). }\end{array}$ \\
\hline
\end{tabular}

Um momento bastante importante dessa atividade com o jogo, já que seu objetivo principal era a síntese de proteínas, foi a leitura em voz alta das cartasobjetivos pelos grupos. Para os alunos da Educativa, esse momento ocorreu antes do início da partida e para os alunos do Álvaro Guião somente ao término do jogo. Através desses momentos os alunos puderam se familiarizar com alguns exemplos de proteínas e diversas funções que podem desempenhar no nosso organismo, como mostrado na seqüência 8, a título de exemplo. 


\section{Seqüência 8- Álvaro Guião (Apêndice G)}

\begin{tabular}{|c|c|}
\hline MICHAEL & $\begin{array}{l}\text { [0:58:00] Sintetizar um molécula de "pró-insulina" num } \\
\text { grânulo de secreção, para que após a alimentação, } \\
\text { seja transformada em insulina e liberada. A minha } \\
\text { ficaria aqui... (apontando para o grânulo de } \\
\text { secreção) }\end{array}$ \\
\hline JULIO & [0:58:12] No caso ficaria aqui né... o seu era o da insulina? \\
\hline MICHAEL & [0:58:16] Isso, insulina \\
\hline$\underline{\text { JULIO }}$ & $\begin{array}{l}\text { [0:58:18] Então por isso que no caso da diabete... quem tem } \\
\text { problema de diabete, é que o organismo não } \\
\text { consegue produzir essa proteína aí, insulina. Por } \\
\text { isso que a pessoa tem que "injetar" insulina todo dia, } \\
\text { porque o organismo não consegue. O seu qual que } \\
\text { é? (JAMES) }\end{array}$ \\
\hline JAMES & $\begin{array}{l}\text { [0:58:35] O meu é queratina. "Para criar uma barreira de } \\
\text { proteção da sua pele, você precisa produzir uma } \\
\text { molécula de queratina e destina-la ao citosol". }\end{array}$ \\
\hline JULIO & [0:58:45] O que é a queratina? Onde ela está? \\
\hline JAM & 0:58:48] Queratina \\
\hline
\end{tabular}

Os resultados obtidos com a pós-entrevista, aplicada cerca de 1 mês após a intervenção com o jogo, e discutidos na seção 4.2.3, nos ajudam a discutir a respeito do papel do mesmo no processo de ensino e aprendizagem. Vimos na pósentrevista que alguns alunos apresentaram evolução de alguns conceitos, ou seja, o jogo os ajudou a reformular alguns conceitos e ampliar outros.

Com relação à 'onde podemos encontrar proteínas', percebeu-se que os alunos, em geral, fizeram menção às estruturas abordadas no jogo, através das situações-problema, como "ah, na pele né, melanina” (James, EEAG), “todos os tecidos do nosso corpo... o que eu peguei era do movimento do tendão" (Maurício, EEAG), "eu sei que no sangue, no olho, na pele, acho que em quase tudo" (Priscila, Educativa). Em especial, o aluno Michael declarou que "achava que era só nos músculos... aí eu vi no caso da insulina, um hormônio, a criatina (queratina), no cabelo..." e acrescentou "pois é, os hormônios, eu nunca tinha pensado assim... ajudou a abrir um pouco a visão que eu tinha sobre as proteínas”. Ao falarem sobre 
o papel das proteínas, apresentaram declarações como "bom, adrenalina o que ela faz? Ela aumenta a circulação do sangue, seria isso?... tem a melanina também que produz o pigmento da pele né...” (Paulo, Educativa), “antigamente eu só achava que era construir e reparar, mas agora vejo que não é si isso, por exemplo a insulina, outros hormônios, a criatina (queratina) presente no cabelo, unha, são mais pra manter o organismo..." (Michael, EEAG), "então, no caso da melanina, dar cor a nossa pele, proteger também dos raios solares, do ultra-violeta..." (James, EEAG). Percebemos também que ao formularem suas respostas, remeteram aos papéis desempenhados pelas proteínas referidas no jogo.

Mesmo não tendo sido discutido diretamente com os alunos a respeito do metabolismo das proteínas, a pós-entrevista revelou um resultado interessante. No questionário diagnóstico e pré-entrevista, a maioria dos alunos mencionam 'quebra' das proteínas durante o processo de digestão, mas sem mencionar essa quebra em aminoácidos. Porém, após o jogo, o aluno Michael respondeu "a gente ingere proteína, aí a saliva e tipo outros... quebram a proteína em aminoácidos, pra formar novas proteínas para as células" e segundo ele "eu lembro que conversamos durante o jogo e você explicou como funcionava".

Relacionado ao processo de síntese protéica, ao descreverem suas etapas os alunos não fizeram menção direta à 'transcrição' ou à 'tradução' e sim apresentaram expressões que lembram as etapas do jogo. Para o processo de transcrição, tivemos respostas como "o DNA vira RNA" (James, EEAG), "a partir do DNA que forma o RNA" (Guto, Educativa) ou "quebra na metade (DNA), faz o RNA mensageiro ligando um com o outro" (Breno, Educativa). Para o processo de tradução, tivemos respostas do tipo "aí sai do núcleo e vai o ribossomo... o RNAt junto pra fazer a seqüência de aminoácidos...” (Mateus, Educativa), "O RNA sai, vai 
para o ribossomo... aí lá pega o RNAm, para poder pegar os aminoácidos, o RNAt carrega os aminoácidos" (Paulo, Educativa), "vai para o ribossomo... daí faz os RNAs transportadores" (Breno, Educativa), "a cadeia do RNA que determina quais aminoácidos vão ser unidos... então os RNAs transportadores é que vão levar os aminoácidos em direção ao RNA mensageiro" (Guto, Educativa) e "pega o trio e transforma em proteína” (James, EEAG).

Ao entendermos o jogo "Sintetizando Proteínas" enquanto um jogo de regras, devemos analisá-lo tanto do ponto de vista de seu caráter simbólico (imaginário) quanto de seu caráter coletivo (gera competição). Do ponto de vista simbólico, proporcionou aos alunos a concretização de um processo que só é entendido no âmbito do imaginário, a síntese de uma proteína. Ou seja, no momento em que através do jogo os alunos assumiram papéis de moléculas e, 'mergulhando' no microscópico 'mundo' celular simularam mecanismos e processos que estão fora de seus limites perceptuais, assemelharam-se a crianças que realizam no brinquedo seus 'desejos não-realizáveis', criando-se assim uma 'zona de desenvolvimento proximal' nos alunos (VYGOTSKY, 1991b, p.106). Do ponto de vista coletivo, em que se associou a síntese de uma determinada proteína ao ato de 'vencer' do aluno, estimulou neles o desenvolvimento de habilidades importantes como, 'tomada de decisão', 'fazer antecipações', 'coordenar situações' e 'ter condutas estratégicas' (MACEDO, 1995).

Segundo Oliveira (1997), a relações entre desenvolvimento e aprendizado e a concepção de 'zona de desenvolvimento proximal' "estabelece forte ligação entre o processo de desenvolvimento e a relação do indivíduo com seu ambiente sóciocultural", no momento em que esse indivíduo só se desenvolve em sua plenitude com o suporte de outros indivíduos de mesma espécie. Dessa forma a autora afirma 
que "é na 'zona de desenvolvimento proximal' que a interferência de outros indivíduos é a mais transformadora". Partindo do pressuposto que o aluno não tem condições de percorrer sozinho o caminho do aprendizado, a intervenção de outras pessoas, como o professor ou os próprios colegas, é fundamental para o seu desenvolvimento.

Mesmo sabendo que o processo de desenvolvimento não é igual para todos os alunos e que tão pouco podemos estabelecer padrões de tempo entre os níveis de desenvolvimento de um indivíduo, podemos inferir que os avanços conceituais percebidos na pós-entrevista tiveram forte influência da intervenção com o jogo.

\subsubsection{Aplicação do jogo com as turmas: A ação dos tutores}

Para esta etapa contamos com a participação dos 15 alunos da amostra, convidados para nos auxiliar na aplicação do jogo com as turmas, sendo 3 alunos no $2^{\circ}$ D e 3 no $2^{\circ} \mathrm{G}$ do Álvaro Guião, 3 alunos no $2^{\circ} \mathrm{A}$ e 6 no $2^{\circ} \mathrm{B}$ da Educativa. Para a ocasião dispúnhamos de um kit contendo 5 protótipos do jogo, de forma que em cada turma pudemos trabalhar com até 5 grupos. Como o nosso fator limitante eram os tutores, trabalhamos em cada turma com uma média de 3 a 5 grupos. Padronizamos que cada grupo seria composto de 8 participantes, em 4 duplas, pois uma quantidade excessiva de alunos por jogo poderia torna-lo inviável. Nas turmas com apenas 3 tutores, com exceção do $2^{\circ} D$ do Álvaro Guião, o mestrando também atuou como tutor, a fim de que pudéssemos preservar o limite de alunos por jogo estipulado inicialmente. 
A função dos tutores compreendeu desde a introdução das regras do jogo aos participantes quanto a fiscalização do andamento das partidas, esclarecendo possíveis dúvidas conceituais ou técnicas. Dessa forma, o mestrando ficou mais livre para circular entre os tutores, auxilia-los e também questionar os alunos dos grupos a cerca do que estavam fazendo naquela etapa do jogo. O registro dos dados foi feito através de gravação audiovisual e anotações em um 'diário de campo'. Nessa ocasião o mestrando pôde fazer algumas considerações gerais sobre a aplicação do jogo com as turmas e a ação dos tutores:

- A aplicação dos jogos foi feita em aulas duplas, portanto de aproximadamente $1 \mathrm{~h}$ e $40 \mathrm{~min}$. Não teve nenhum grupo que não conseguiu terminar o jogo dentro desse prazo. Em geral o tempo de execução do jogo com cada turma oscilou entre $1 \mathrm{~h}$ e $1 \mathrm{~h}$ e $30 \mathrm{~min}$, mesmo considerando o tempo inicial, de preparação dos grupos;

- Alguns tutores precisaram ser orientados antes e durante a execução dos jogos, pois não lembravam das regras;

- Em alguns grupos os alunos estavam inquietos e o tutor apresentou dificuldade em explicar as regras, sendo preciso a intervenção do professor da turma ou do mestrando;

- Uma das maiores dificuldades apresentadas pelos tutores estava em iniciar as partidas, explicar as regras iniciais.

Ao término das aplicações dos jogos, os tutores foram convidados a responder a um breve questionário (ver Apêndice F), em que os mesmos puderam expressar suas opiniões a cerca das suas experiências em conduzir a atividade, expor suas dificuldades e propor sugestões. A análise dos questionários revelou que para $40 \%$ (6) dos tutores a experiência foi fácil, não tendo dificuldade em explicar as 
regras e conduzir o jogo com os colegas. Já os outros $60 \%$ (9) deles tiveram dificuldade em conduzir a atividade, sendo suas principais queixas: "não lembravam do assunto, inclusive eu" (5); "me confundia ao passar de fase, e a quantidade de alunos foi pesado para mim" (1); "o grupo era muito disperso" (2) e; "a ordem das etapas é um pouco complexa, tornaria mais fácil escreve-las em um manual”(1).

A experiência com os tutores foi bastante positiva e o fato de $60 \%$ deles apresentar dificuldade em conduzir a atividade não invalida a proposta, pois a maioria das dificuldades apresentadas, tanto pelo mestrando quanto pelos tutores, remetiam a características particulares da turma em que foi aplicada a atividade. Nesse caso não podem ser tomadas como generalizações. Se retomarmos as restrições apresentadas pelos professores à aplicação do jogo em sala de aula (ver tabela 4.1), veremos que essa proposta de aplicação do jogo mediada por alunos tutores atende aos principais fatores apresentados por eles, como tempo, necessidade de mediação e quantidade de alunos por jogo.

Dentre as observações feitas pelos tutores, tivemos alguns relatos que expressavam suas experiências e motivações, como:

"Eu adorei a experiência, achei super interessante e divertida, porém, achei que faltou colaboração dos colegas na hora de aplicar o jogo, pois eles não queriam saber das regras e apenas reclamaram".

"Percebi que quando você está monitorando o jogo, fica mais fácil para entender e guardar as informações".

"Alguns colegas demonstraram desinteresse, mas aqueles que participaram ativamente do jogo gostaram dele".

Porém outros aproveitaram para sugerir algumas modificações quanto à dinâmica do jogo e público alvo:

"Acho que a dificuldade do jogo poderia ser maior. Quando jogávamos criei uma variável para a última parte do jogo (5 - destinar proteína) fazendo com que os jogadores tivessem que de fato destinar a proteína para o local correto, correndo o risco de voltar ao início. Fora a dificuldade um tanto baixa, o jogo sana dúvidas dos jogadores e pode (e deve) ser aplicado em classes do ensino fundamental e médio como introdução a Citologia e Síntese protéica". 
"Na minha opinião o jogo ajuda a entender o assunto, as regras estão claras e seria uma ótima atividade para ser aplicada no $1^{\circ}$ ano, após a aprendizagem do assunto para assim ser fixado melhor e entendido com clareza".

“Jogo fácil e rápido, porém muitos alunos não se importam em qual proteína estão formando! Seria interessante acrescentar algo ao jogo que aumente seu interesse nesta área. Os alunos gostam de atrapalhar seus adversários. Não sei se é viável, mas aconselho a invenção de mais cartas 'protease' e 'RNAse'”.

Com isso, este estudo piloto utilizando alunos tutores como mediadores na aplicação do jogo, contribuiu tanto para a sua avaliação em uma situação real de sala de aula, quanto para a proposição de futuras modificações para sua adequação à realidade escolar dos professores de Biologia. 


\section{CAPÍTULO 5}

CONCLUSÕES 

Considerando as questões de pesquisas apresentadas no final do capítulo 1

e os resultados oriundos deste trabalho, apresentaremos a seguir algumas conclusões:

- Com relação aos tipos de concepções dos alunos sobre 'proteínas', detectamos, durante a análise dos questionários diagnósticos, 'tendências' do pensar (formas comuns de pensamento, elucidadas por meio das categorias de resposta) que tiveram recorrência em outras etapas do trabalho, como na pré e pós-entrevista. Um exemplo seria a simplificação observada entre os alunos ao definirem proteínas (tendência Em definir genericamente o papel das proteínas no organismo (humano)), mantidas nas pré- e pósentrevistas de alguns alunos. Neste caso podemos inferir se tratar de uma concepção alternativa, em que uma das principais características é o fato de serem resistentes à mudança;

- As interações promovidas pelo jogo bem como o contato dos alunos com diferentes tipos de proteínas (por meio das cartas-objetivo) foram essenciais para a evolução de alguns conceitos por parte de alguns alunos, superando a tendência inicial observada entre eles de entenderem as proteínas apenas como ‘construtoras' de tecidos, portanto com uma função prioritariamente estrutural. Nesse caso podemos supor que as interações proporcionadas pelo jogo influenciaram o processo de ensino-aprendizagem dos alunos na promoção de uma aprendizagem significativa, prospectiva, ou seja, voltada para a 'zona de desenvolvimento proximal'; 
○ O bom nível de conhecimento com relação a determinados conceitos observado entre os alunos da escola Educativa, quando comparado aos da escola Álvaro Guião, pode ser explicado por fatores como: a escola possui poucas turmas de ensino médio, que são formadas por alunos que em sua maioria iniciam e terminam seu curso naquela escola; um único professor assume as aulas de biologia das três turmas do ensino médio, acompanhando-os durante todo esse período. Trata-se apenas de uma hipótese, não podemos sustentar generalizações a respeito dos sistemas de ensino envolvidos, baseados apenas em casos particulares;

- O recrutamento de alunos para a função de tutores pode ser uma eficiente estratégia de auxílio ao professor na aplicação do jogo em sala de aula.

Nesse contexto, o jogo 'Sintetizando Proteínas' teve um impacto positivo no processo de ensino-aprendizagem do tema 'proteínas e síntese protéica' entre alunos do $2^{\circ}$ ano do ensino médio. $O$ jogo, enquanto um modelo que simula 0 processo de síntese protéica dentro da célula, proporcionou aos alunos experiências que os permitiram 'vivenciar' esse processo, estabelecendo uma ponte entre o abstrato e o concreto, possibilitando aos mesmos o alcance de níveis de desenvolvimento mais elevados e a evolução de conceitos antes incompreendidos. Por ser um jogo de regras, pode, ainda, proporcionar o desenvolvimento de habilidades como o respeito às regras, a disciplina, a competição, o raciocínio estratégico, além de proporcionar a diversão. 


\section{REFERÊNCIAS*}

ARAUJO-JORGE, T. C. et al. Microscopy images as interactive tools in cell modeling and cell biology education. Cell Biology Education, v. 3, n. 3, p. 99-110, 2004.

$\mathrm{ASH}, \mathrm{V}$. The report card comment generator: a model to help explain the relationship between genes and alleles. Journal of Biological Education, v. 35, n. 2, p. 100-1001, 2001.

ASMUS, E. G. Protein structure. The American Biology Teacher, v. 59, n. 1, p. 38-43, 2007.

ATKINS, T.; RODERICK, J. Demonstration: genetic jewelry. The American Biology Teacher, v. 68, n. 6, p. 80-85, 2006.

BAKER, W. P.; JONES, C. B.; HULL, E. Modeling protein domain function. Science Activities, v. 44, n. 2, p. 43-46, 2007.

BANTA, L. DNA - How sweet it is!. The American Biology Teacher, v. 59, n. 8, p. 511-512, 1997.

BELTRAMINI, L, M. et al. A new three-dimensional educational model kit for building DNA and RNA molecules. Biochemistry and Molecular Biology Education, v. 34, n. 3, p. 187-193, 2006.

BIERMANN, C. A. The protein a cell built (and the house Jack built). The American Biology Teacher, v. 50, n. 3, p. 162-163, 1988.

BOGDAN, R.; BIKLEN, S. Investigação qualitativa em Educação: uma introdução à teoria e aos métodos. Porto: Porto editora, 1994.

BANTA, L. DNA - how sweet it is! The American Biology Teacher, v. 59, n. 8, p. 511512, 1997.

\footnotetext{
* De acordo com:

ASSOCIAÇÃO BRASILEIRA DE NORMAS TÉCNICAS. NBR 6023: informação e documentação: referências: elaboração. Rio de Janeiro, 2002.
} 
BONZANINI, T. K.; BASTOS, F. Concepções de alunos do ensino médio sobre clonagem, organismos transgênicos e projeto genoma. Atas do ENPEC - n.5, ISSN 1809-5100, 2005.

BRAGA, M. C. Cooperativa educacional de São Carlos - Educativa: Uma experiência entre o público e o privado em educação. 1998. 304f. Dissertação (mestrado em educação) - Centro de Educação e Ciências Humanas, Universidade Federal de São Carlos, São Carlos, 1998.

BRASIL, MINISTÉRIO DA EDUCAÇÃO (MEC), SECRETARIA DE EDUCAÇÃO MÉDIA E TECNOLÓGICA (SEMTEC). Parâmetros Curriculares Nacionais - Ensino Médio: Parte 3 - Ciências da natureza, matemática e suas tecnologias. Brasília: MEC/Semtec, 1999. p. 201-279.

BRASIL, MINISTÉRIO DA EDUCAÇÃO (MEC), SECRETARIA DE EDUCAÇÃO MÉDIA E TECNOLÓGICA (SEMTEC). PCN+Ensino Médio: orientações educacionais complementares aos Parâmetros Curriculares Nacionais - Ciências da natureza, matemática e suas tecnologias. Brasília: MEC/Semtec, 2002.

BRINNER, B. Of molecules and models. Science Scope, v. 15, n. 7, p. 14-17, 1992.

CACHAPUZ, A. et al. A necessária renovação do ensino das ciências. São Paulo: Editora Cortez, 2005.

CAKICl, Y. Exploring Turkish upper primary level pupils' understanding of digestion. Journal of Science Education, v. 27, n. 1, p. 79-100, 2005.

CLEMENTS, L. A. J.; JACKSON, K. E. Protein synthesis - an interactive game. The American Biology Teacher, v. 60, n. 6, p. 427-429, 1998.

CORN, J.; PITTENDRIGH, B. R.; ORVIS, K. S. Genomics analogy model for educators (GAME); from jumping genes to alternative splicing. Journal of Biological Education, v. 39, n. 1, p.24-26, 2004.

CROWTHER, D. T.; LANDON, J.; JACOBITZ, K. Protein potluck: doing tasteful science. The American Biology Teacher, v. 59, n. 2, p. 108-112, 1997.

DAVIES, G. Nuggets, stories, fun and games: teaching genetics in primary school. Journal of Biological Education, v. 40, n. 1, p. 31-31, 2005. 
DIAS, M. C. M. Metáfora e pensamento: considerações sobre a importância do jogo na aquisição do conhecimento e implicações para a educação pré-escolar. In: KISHIMOTO, T. M. Jogo, brinquedo, brincadeira e a educação. São Paulo: Cortez, 1996. p. 45-56.

DRIVER, R. et al. Construindo conhecimento científico na sala de aula. Química Nova na Escola, 1999. Disponível em: <http://qnesc.sbq.org.br/online/qnesc09/>. Acesso em: 13 out. 2008.

FALK, H.; BRILL, G.; YARDEN, A. Teaching a biotechnology curriculum based on adapted primary literature. International Journal of Science Education, v. 1, n. 1, p. 1-26, 2008.

FINK, P. A. An interactive 3D model of protein synthesis. The American Biology Teacher, v. 52, n. 5, p. 274-275, 1990.

GARCIA-MILÀ, M. O ensino e a aprendizagem das ciências físico-naturais: uma perspectiva psicológica. In: COLL, C.; ÁLVARO, M.; PALACIOS, J. (Org.) Desenvolvimento psicológico e educação - Psicologia da educação escolar. Tradução Daisy Vaz de Moraes. 2. ed. Porto Alegre: Artmed, 2004, v. 2. p.361-366.

GIL, A. C. Métodos e técnicas de pesquisa social. 5. ed. São Paulo: Atlas, 1999.

KIRKPATRICK, G.; ORVIS, K.; PITTENDRIGH, B. A teaching model for biotechnology and genomics education. Journal of Biological Education, v. 37, n. 1, p. 31-35, 2002.

KISHIMOTO, T. M. Jogo, brinquedo, brincadeira e a educação. São Paulo: Cortez, 1996. p. $45-55$.

LEWIS, A.; PEAT, M.; FRANKLIN, S. Understanding protein synthesis: an interactive card game discussion. Journal of Biological Education, v. 39, n. 3, p. 125-130, 2005.

LEWIS, J.; WOOD-ROBINSON, C. Genes, chromosomes, cell division and inheritance - do students see any relationship? Journal of Science Education, v. 22, n. 2, p. 177-195, 2000.

LEWIS, J. Traits, genes, particles and information: re-visiting students' understandings of genetics. International Journal of science education, v. 26, n. 2, p. 195-206, 2004. 
LEWIS, J.; LEACH, J.; WOOD-ROBINSON, C. All in the genes? young people's understanding of the nature of genes. Journal of Biological Education, v. 34, n. 2, p. 74-79, 2000a.

LEWIS, J.; LEACH, J.; WOOD-ROBINSON, C. What's in a cell? young people's understanding of the genetic relationship between cells, within an individual. Journal of Biological Education, v. 34, n. 3, p. 129-132, $2000 \mathrm{~b}$.

LOCK, R. Post-16 biology - some model approaches? School Science Review, v. 79, n. 286, p. 33-39, 1997.

LÜDKE, M.; ANDRÉ, M. E. D. A. Pesquisa em educação: abordagens qualitativas. São Paulo: EPU, 1986.

MACEDO, L. Os jogos e a sua importância na escola. Caderno de Pesquisa, n. 93, p. 5-10, 1995.

MACEDO, L., PETTY, A. L. S., PASSOS, N. C. Aprender com jogos e situaçõesproblema. Porto Alegre: Artes Médicas Sul, 2000.

MACEDO, L., PETTY, A. L. S., PASSOS, N. C. Os jogos e o lúdico na aprendizagem escolar. Porto Alegre: Artemed, 2005.

MARBACH-AD, G. Attempting to break the code in student comprehension of genetic concepts. Journal of Biological Education, v. 35, n. 4, p. 183-189, 2001.

MARTÍNEZ-GRACIA, M. V.; GIL-QUÍLEZ, M. J. Genetic engineering: a matter that requires further refinement in Spanish secondary school textbooks. International Journal of Science Education, v. 25, n. 9, p. 1147-1168, 2003.

MENSCH, D. L.; RUBBA, P. A. A study of large hands-on protein synthesis models in a biology class. School Science and Mathematics, v. 91, n. 4, p. 164-168, 1991.

MORTIMER, E. F. Conceptual change or conceptual profile change? Science and education, v. 4, n. 3, p. 267-285, 1995. 
NELSON, A.; GOETZE, J. Modeling protein folding applying it to a relevant activity. The American Biology Teacher, v. 64, n. 4, p. 287-289, 2004.

NOSELLA, P., BUFFA, E. Schola mater. a antiga escola normal de São Carlos 1911-1933. São Carlos: EDUFScar, 1996.

O'DAY, D. H.Using animations to teach biology: past \& future research on the attributes that underlie pedagogically sound animations. The American Biology Teacher, v. 70, n. 5, p. 274-278, 2008.

OLIVEIRA, M. K. Vygotsky e a formação de conceitos. In: LE TAILLE, Y.; OLIVEIRA, M. K. ; DANTAS, H. Piaget, Vygotsky e Wallon: teorias psicogenéticas em discussão. 18. ed. São Paulo: Summus, 1992. p. 26-34.

PAVAN, O. H. O. Jogos didáticos: evoluindo-genética. In: CAUÊ, M., ALVES, O. L. Conhecimento científico e vida cotidiana. São Paulo: Terceira Margem, 2003. p.175180.

PEDRANCINI, V. D. et al.. Ensino e aprendizagem de Biologia no ensino médio e a apropriação do saber científico e biotecnológico. Revista Electrónica de Enseñanza de las Ciências, v. 6, n. 2, p. 299-309, 2007.

PIGAGE, H. K. The central dogma in action. The American Biology Teacher, v. 53, n. 7, p.436-437, 1991.

RIBEIRO, M. P. O. Jogando e aprendendo a jogar: funcionamento cognitivo de crianças com história de insucesso escolar. São Paulo: EDUC, 2005.

RODE, G. A. Teaching protein synthesis using a simulation. The American Biology Teacher, v. 57, n. 1, p. 50-52, 1995.

ROGERSON, A. C.; CHENEY JUNIOR, R. W. A physical model illustrating protein synthesis on the ribosome. The American Biology Teacher, v. 51, n. 1, p. 29-31, 1989.

ROTHHAR, R.; PITTENDRIGH, B. R.; ORVIS, K. S. The Lego ${ }^{\circledR}$ analogy model for teaching gene sequencing and biotechnology. Journal of Biology Education, v. 40, $n$. 4, p. 166-171, 2008. 
SÁEZ, M. J.; NIÑO, A. G.; CARRETERO, A. matching society salues: students' views of biotechnology. International Journal of Science Education, v. 30, n. 2, p. 167-183, 2008.

SANTOS, M. E. V. M. Tendências e resultados no interior da linha de investigação sobre concepções alternativas. In: - Mudança conceptual em sala de aula: um desafio pedagógico. Lisboa: Livros horizonte, 1991. p. 91-127.

SANTOS, W. L. P.; SCHNELTZER, R. P. Educação em Química: compromisso com a cidadania, 2. ed. ljuí: Editora Unijuí, 2000.

SEIPELT, R. L. Cookie-ases: interactive models for teaching genotype-phenotype relationships. The American Biology Teacher, 2006. Disponível em: <

http://www.nabt.org/sites/S1/index.php?p=318>. Acesso em: 10 out. 2008.

SILVA, M. A. R.; LETA, J. As moléculas da hereditariedade. Ciência Hoje, v. 38, n. 227, p. 64-66, 2006.

SMIT, L. A.; WILLIANS, J. M. "It's the $X$ and $Y$ thing": cross-sectional and longitudinal changes in children's understanding of genes. Research in Science Education, v. 37, n. 3, p. 407-422, 2007.

SPREHN, J. L. Protein building blocks: a concrete model for an abstract thought. The Science Teacher, v. 60, n. 7, p. 22-25,1993.

STENCEL, J.; BARKOFF, A. Protein synthesis: role playing in the classroom. The American Biology Teacher, v. 55, n. 2, p. 102-103, 1993.

TEMPLIN, M. A.; FETTERS, M. K. A working model of proteins synthesis using Lego ${ }^{\circledR}$ building blocks. The American Biology Teacher, v. 64, n. 9, p. 673-678, 2002.

TURNER, H. M. Simulation and demonstration: the nature of enzymes and how they are denatured. The American Biology Teacher, v. 69, n. 3, p. 142, 2007.

VASQUEZ, J. AV \& software review. The American Biology Teacher, v. 65, n. 7, p. 548-551, 2003.

VOLPATO, G. Jogo e brinquedo: reflexões a partir da teoria crítica. Educação \& Sociedade, v. 23, n. 81, p. 217-226, 2002. 
VYGOTSKY, L.S. Pensamento e linguagem. Tradução Jeferson Luiz Camargo. 3. ed. São Paulo: Martins fontes, 1991a.

A formação social da mente: o desenvolvimento dos processos psicológicos superiores. Tradução José Cipolla Neto; Luis Silveira Menna Barreto; Solange Castro Afeche. 4. ed. São Paulo: Martins fontes, 1991b.

WILLMOTT, C. J. R. Revision bingo. Biochemistry and Molecular Biology Education, v. 29, n. 5, p. 193-195, 2001.

WOOD-ROBINSON, C.; LEWIS, J.; LEACH, J. Young people's understanding of the nature of genetic information in the cells of an organism, Journal of Biological Education, v. 35, n. 1, p. 29-36, 2000. 


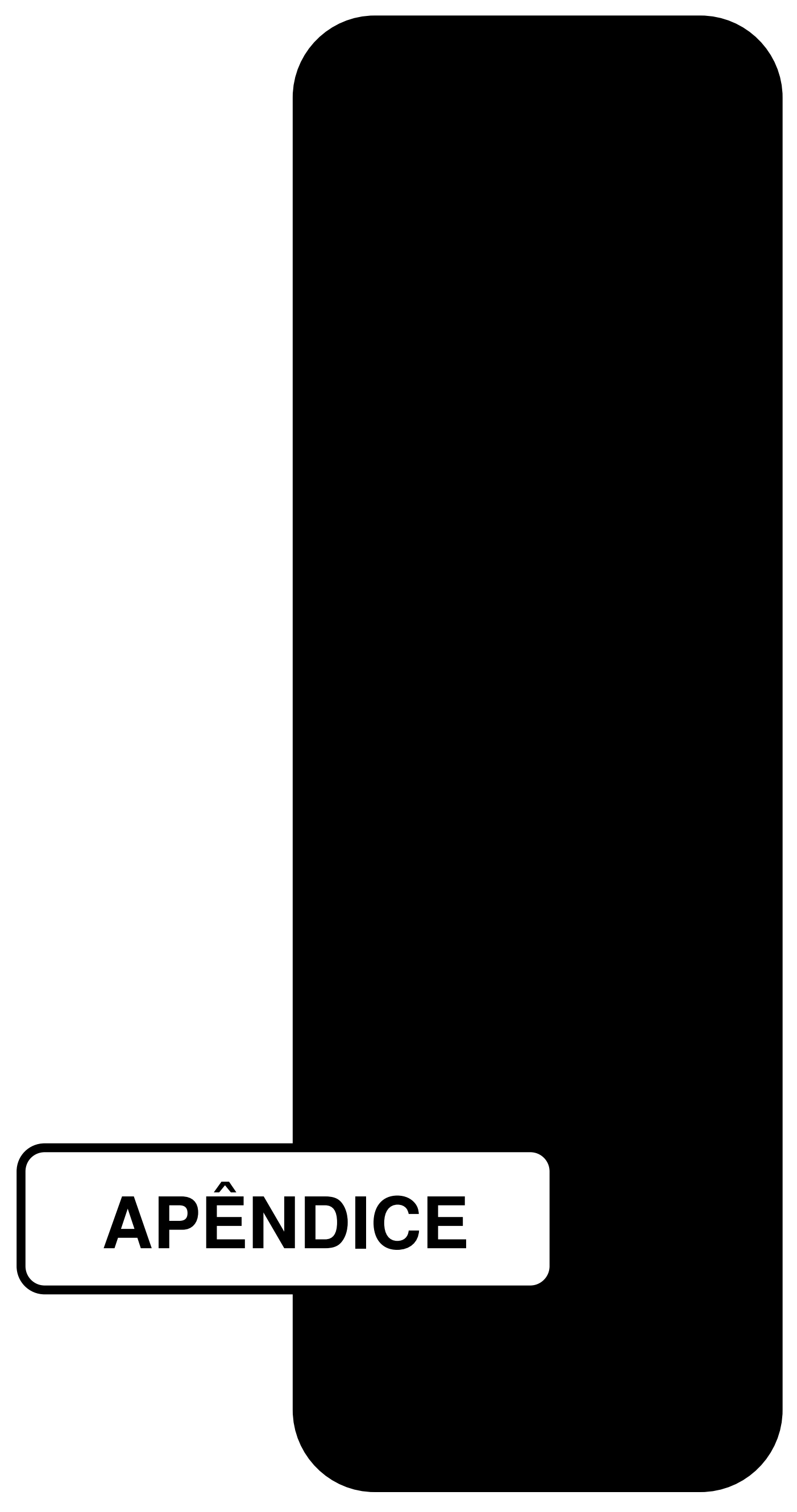





\section{APÊNDICE A \\ PRÉ-AVALIAÇÃO DO JOGO: TESTE APLICADO AOS PROFESSORES}
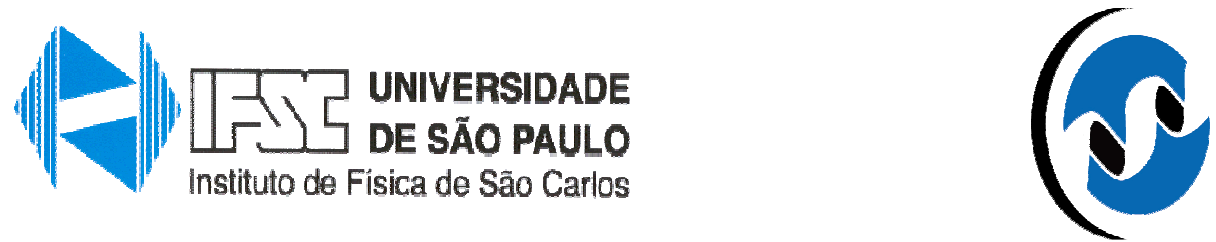

CBME

Centro de

Biotecnologia

Molecular

Estrutural

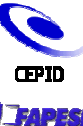

\section{Centro de Biotecnologia Molecular Estrutural}

\section{Coordenadoria de Difusão do CBME}

Estamos realizando uma pesquisa entre professores de Biologia do Ensino Médio que manipularam o jogo "Sintetizando Proteínas", com o intuito de fazer uma pré-avaliação do mesmo quanto a sua eficiência e aplicabilidade em sala de aula. Essa pesquisa contribuirá para futuras modificações no sentido de torna-lo cada vez mais próximo da realidade de sala de aula e possa se confirmar enquanto uma ferramenta didática de auxílio ao professor.

\section{Fale um pouco sobre você...}

Nome:

Escola em que leciona:

1.1. Qual a sua formação inicial (graduação)?

Curso:

Instituição:

Ano de conclusão:

1.2. Fez (ou faz) algum curso de pós-graduação?

( ) Sim ( ) Não

1.3 Em caso afirmativo, trata-se de um curso de qual nível?

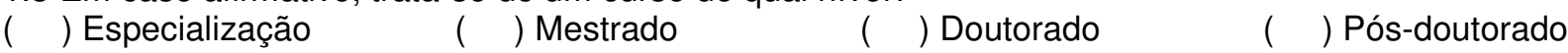

1.4 Costuma participar de cursos de formação continuada? （） Sim ～～Não

1.5 Em caso afirmativo, com que freqüência participa desses cursos?
( ) Mensal
( ) Semestral
( ) Anual
( ) Eventual/Esporádica

1.6 Onde esses cursos são oferecidos?
( ) Na escola em que trabalho (
( ) Universidades/faculdades privadas
) Diretoria de Ensino
( ) CDCC/USP
( ) Universidades Públicas
( ) Outras Instituições:

\section{Atuação profissional}

2.1. Há quanto tempo atua em sala de aula?

2.2. Nesse período, sua atuação foi:

\section{( ) Somente em escolas públicas}

( ) A maior parte do tempo em escolas públicas

( ) Somente em escolas privadas

( ) Em escolas públicas e privadas, igualmente 
2.3. Em qual (quais) instituição (instituições) você trabalha atualmente?

2.4. Em caso de escola pública, qual é seu vínculo com a instituição?
( ) Titular de cargo efetivo
( ) ACT
( ) Eventual

2.5. Em média, qual é a sua a carga horária/aula semanal? Costumam ter aulas duplas?

2.7. Você costuma utilizar outros recursos didáticos que não somente lousa e livro didático? Quais?

2.8. Como você normalmente aborda o tema síntese de proteínas com seus alunos? Qual o nível de informações que chega a discutir?

3. Quanto ao Jogo "Sintetizando Proteínas"...

Marque com um $x$ o item a direita que melhor traduzir a sua expressão com relação aos aspectos avaliados

\begin{tabular}{|l|l|l|l|l|l|l|}
\hline NNo & \multicolumn{1}{|c|}{ Aspectos avaliados } & ótimo & $\begin{array}{c}\text { muito } \\
\text { bom }\end{array}$ & bom & regular & ruim \\
\hline $\mathbf{1}$ & Quanto ao design do tabuleiro e materiais & & & & & \\
\hline $\mathbf{2}$ & Quanto à clareza das regras do jogo & & & & & \\
\hline $\mathbf{3}$ & $\begin{array}{l}\text { Quanto à complexidade e nível das informações } \\
\text { abordadas no jogo. }\end{array}$ & & & & & \\
\hline $\mathbf{4}$ & $\begin{array}{l}\text { O jogo enquanto um estimulador do raciocínio } \\
\text { reflexivo, fazendo contextualizações. }\end{array}$ & & & & & \\
\hline $\mathbf{5}$ & $\begin{array}{l}\text { O jogo enquanto um estimulador da } \\
\text { curiosidade, fazendo-os conhecer onde as } \\
\text { proteínas são formadas, como atuam e sua } \\
\text { importância para nós. }\end{array}$ & & & & & \\
\hline $\mathbf{6}$ & $\begin{array}{l}\text { O jogo enquanto um facilitador do } \\
\text { conhecimento, no caso do processo de síntese } \\
\text { de proteínas. }\end{array}$ & & & & & \\
\hline $\mathbf{7}$ & $\begin{array}{l}\text { Quanto ao nível de interação entre os } \\
\text { participantes }\end{array}$ & & & & & \\
\hline
\end{tabular}

8. Na sua opinião, levando-se em conta o tempo médio de duração do jogo e o tempo disponível, o jogo é aplicável em sala de aula? Comente e dê sugestões. 


\section{APÊNDICE B \\ PROJETO E PLANO DE AÇÃO APRESENTADO AOS PROFESSORES PARCEIROS}

\section{Introdução}

O Centro de Biotecnologia Molecular Estrutural (CBME), com sede no Instituto de Física da USP de São Carlos (IFSC), em parceria com o Centro de divulgação Científica e Cultural de São Carlos (CDCC), desenvolveu uma ferramenta didática na forma de um jogo, intitulado "Sintetizando Proteínas". Este jogo tem por objetivo tornar-se um facilitador do conhecimento entre alunos do Ensino Médio no que diz respeito ao tema "proteínas", uma vez que alia conhecimento à descontração, diversão.

Este jogo, ainda em sua versão piloto, é tema de um projeto de mestrado, vinculado ao IFSC e ao CBME, o qual se propõe a avaliar essa ferramenta didática quanto ao seu impacto no processo de ensino-aprendizagem de alunos do Ensino Médio do tema "proteínas e síntese protéica". Esta avaliação consiste de três etapas: levantamento das concepções dos alunos com respeito a proteínas, a aplicação do jogo propriamente dito e a verificação da aprendizagem. O intuito é ressaltar possíveis potencialidades do jogo.

Nesse processo, a parceria entre pesquisadores, professores, alunos e direção da Escola é imprescindível para o sucesso do projeto. Desse modo gostaríamos de apresentar nossa proposta de trabalho.

\section{Justificativa e objetivo}

Neste trabalho iremos avaliar o impacto do jogo "Sintetizando Proteínas" no processo de ensino-aprendizagem de alunos do Ensino Médio, no que se refere o tema "proteínas e síntese protéica". Essa avaliação tem por finalidade o 
levantamento das potencialidades e falhas desse jogo enquanto uma ferramenta didática proposta.

\section{Questões de pesquisa}

- Que tipo de concepções esses alunos tem ou trazem sobre proteínas antes da aplicação do jogo?;

- Que tipo de interações o jogo promove?;

- Qual a influência dessas interações no processo de aprendizagem dos alunos?;

- Ao comparar os discursos dos alunos antes e depois da aplicação do jogo, percebe-se alguma evolução em termos conceituais?

\section{Metodologia}

Os fundamentos metodológicos desta pesquisa têm suas bases na pesquisa qualitativa (LÜDKE \& ANDRÉ, 1986, BOGDAN \& BIKLEN, 1994).

A pesquisa terá o ambiente natural (escola, sala de aula, professores e alunos) como sua fonte direta de dados e questionários, entrevistas, "diário de campo" e filmagens como seus principais instrumentos de coleta.

\subsection{Procedimentos e instrumentos para coleta de dados}

Para atingir os objetivos propostos, inicialmente será realizado um levantamento das concepções prévias dos alunos sobre a temática a ser desenvolvida. Esse levantamento será feito com alunos do ensino médio. 
Um questionário escrito e entrevistas serão utilizados como instrumentos para a realização do levantamento proposto. O questionário conterá questões abertas e de múltipla escolha e será aplicado a pelo menos 15 alunos de cada série e curso. A sua elaboração será baseada em GIL (1999) e a análise das questões abertas será feita segundo LUDKE e ANDRÉ (1986) e BOGDAN \& BIKLEN (1994), que propõem a distribuição das respostas em categorias.

Após a análise dos questionários respondidos, 4 a 6 alunos de cada turma serão entrevistados quanto ao mesmo conteúdo abordado pelo questionário escrito. A finalidade da entrevista é complementar os dados levantados pelo questionário e identificar mais claramente as concepções dos alunos sobre a temática, o que nem sempre é conseguido pelo primeiro instrumento. A entrevista será do tipo semi-estruturada e sua elaboração e análise serão baseadas em MOREIRA \& SILVEIRA (1993), BOGDAN \& BIKLEN (1994), GIL (1999) e BAUER \& GASKELL (2004).

As informações relativas as concepções prévias apresentadas pelos estudantes, levantadas pelo questionário inicial e entrevistas, serão utilizadas na estratégia de abordagem na aplicação do jogo "Sintetizando Proteínas".

O jogo será aplicado aos grupos de alunos entrevistados. Registros das variáveis envolvidas no ensino e na aprendizagem tais como dificuldades de compreensão dos alunos sobre o que foi proposto ou solicitado no material, motivação e disponibilidade dos alunos para a realização das atividades, bem como as dúvidas relativas ao conteúdo específico abordado serão feitos durante e após o jogo. 
Após um mês passado da aplicação do jogo aos estudantes, os mesmos alunos serão novamente entrevistados. A finalidade dessa etapa é avaliar a evolução dos conceitos, possibilitados pelas interações promovidas pelo jogo.

\section{Forma e Análise dos resultados}

Os resultados obtidos através dos instrumentos de coleta de dados serão analisados quanto: a) compreensão e aplicação em outros contextos, das situações-

problemas propostas pelo jogo; b) Interação social entre os alunos durante a aplicação do jogo, através da análise dos discursos (gravados em áudio e vídeo). 
6. Cronograma de atividades

\begin{tabular}{|c|c|c|c|c|c|c|c|}
\hline \multirow{11}{*}{ 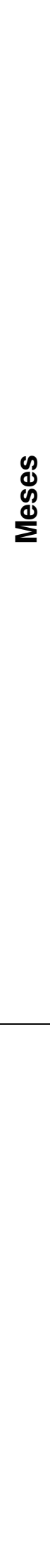 } & & ญे & & & & & \\
\hline & & ? & & & & & \\
\hline & & 亏ै & & & & & $x$ \\
\hline & & $\begin{array}{l}\bar{\Phi} \\
\stackrel{\infty}{*}\end{array}$ & & & & $x$ & \\
\hline & & 용 & & & & $x$ & \\
\hline & & $\overline{3}$ & & & & & \\
\hline & & $\stackrel{5}{丂}$ & & & $x$ & & \\
\hline & & ${ }^{\bar{\pi}}$ & & $x$ & & & \\
\hline & & '⿳亠口冋 & & $x$ & & & \\
\hline & & $\sum^{\frac{1}{\pi}}$ & $x$ & & & & \\
\hline & $\begin{array}{l}\text { o } \\
\frac{0}{0} \\
\frac{\pi}{0} \\
\end{array}$ & & 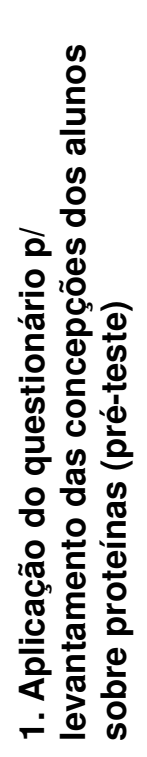 & 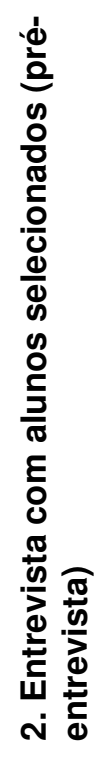 & 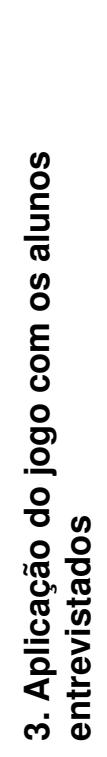 & 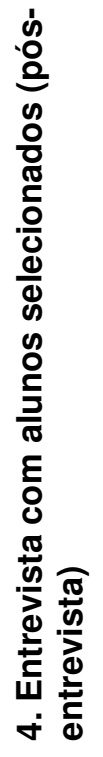 & 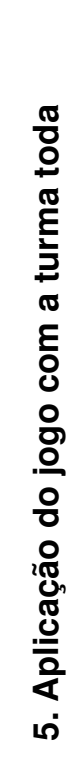 \\
\hline
\end{tabular}




\section{Referências bibliográfica}

BAUER, M.W.; GASKELL, G. (ed.) Pesquisa qualitativa com texto, imagem e som um manual prático. trad. Pedrinho A. Guareschi. Petrópolis, Editora Vozes, 2004.

BOGDAN, R.; BIKLEN, S. Investigação qualitativa em Educação: Uma introdução à teoria e aos métodos. Porto, Porto editora, 1994, Portugal, 335p.

GIL, A.C. Métodos e técnicas de pesquisa social. 5 åed, São Paulo, Atlas, 1999.

LÜDKE, M.; ANDRÉ, M. E. D. A. Pesquisa em educação: abordagens qualitativas. São Paulo. EPU, 1986. 99p.

MOREIRA, M. A.; SILVEIRA, F.L. Instrumentos de pesquisa em ensino e aprendizagem: a entrevista clínica e a validação de testes de papel e lápis. Porto Alegre, EDIPUCSC, 1993. 


\section{APÊNDICE C \\ TERMO DE AUTORIZAÇÃO ENCAMINHADO À DIREÇÃO DAS ESCOLAS}

\section{$\underline{\text { AUTORIZAÇ̃̃̃O }}$}

Segundo o que foi acordado com os(as) professores(as) de Biologia (nome dos professores), em reunião no dia (data da reunião), durante o HTPC, o aluno de pósgraduação do Instituto de Física da USP de São Carlos, Julio Cesar Queiroz de Carvalho, sob minha orientação, apresentou a proposta de uma parceria no desenvolvimento de seu projeto de mestrado, cujo tema é a avaliação de um jogo intitulado "Sintetizando Proteínas", a ser aplicado com as turmas do segundo ano do ensino médio dos referidos professores.

A primeira etapa desse projeto compreende um levantamento estatístico com respeito às concepções dos alunos sobre o tema "proteínas e síntese protéica", em que será utilizado como ferramenta de coleta de dados questionários e entrevista com uma amostragem das turmas, gravadas em áudio. A segunda etapa corresponde à aplicação do jogo com os alunos entrevistados e verificação das dificuldades dos mesmos com a manipulação e suas regras, sendo todas registradas em um "diário de campo" e contaremos também com gravações tanto em áudio quanto em vídeo. A última etapa do projeto compreenderá a aplicação do jogo às turmas de alunos da segunda série com o intuito de verificar a utilização do jogo em situação real de aula.

Nesse sentido vimos por meio desta solicitar autorização para a utilização das dependências da escola na realização do projeto, incluindo a própria sala de aula quanto outro espaço para a realização das entrevistas. Solicitamos ainda permissão para convidar os alunos entrevistados a comparecerem em período oposto para apresentar-lhes o jogo, a fim de formar tutores que irão auxiliar na aplicação do mesmo com as suas respectivas turmas.

Sem mais, agradecemos,

Profa. Nelma R. Segnini Bossolan

Julio Cesar de Queiroz Carvalho

São Carlos, de de de 2007

De acordo

Diretor(a) 


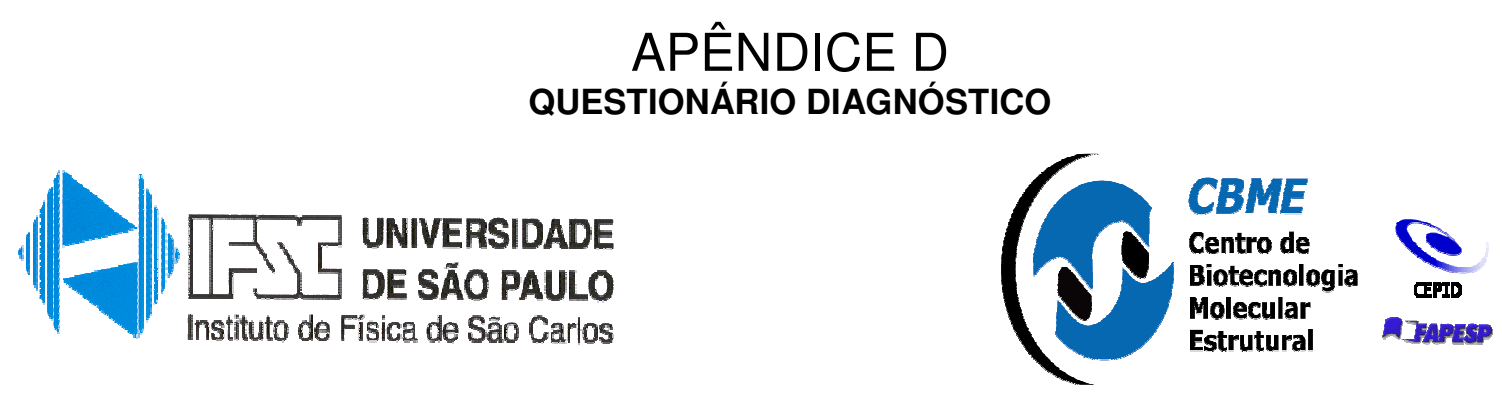

Centro de Biotecnologia Molecular Estrutural

Coordenadoria de Difusão do CBME

Estamos realizando uma pesquisa entre alunos do Ensino Médio, com o intuito de fazer um levantamento sobre suas concepções a respeito de proteínas. Desde o que são, suas principais características e seu papel nos organismos vivos. Gostaríamos de contar com sua colaboração no que se refere a autenticidade das respostas e comprometimento com a pesquisa, pois ela só terá sucesso se for estabelecido laços de confiança e credibilidade entre o pesquisador e você.

CONTE UM POUCO SOBRE VOCÊ...

1. Nome:

2. Idade: 3. Sexo: 4. Série: 5. Período:

6. Escola:

7. Quando foi a última vez que estudou sobre proteínas?

8. Quanto se lembra? ( ) muito ( ) médio ( ) pouco ( ) nada

9a. Você tem acesso a alguma revista de divulgação científica, do tipo Ciência Hoje, Super interessante, Scientific American? ( ) sim ( ) não.

b. Que tipo de acesso: ( ) leio na escola ( ) tenho acesso pela internet ( ) minha família assina

c. Se assinante, qual(ais):

d. Com que freqüência? ( ) todo dia ( ) uma vez por semana ( ) uma vez por mês ( ) dificilmente

10. Tem acesso ou se interessa por programas de televisão, seja em canais abertos seja em TV por assinatura, que discutem sobre Ciência? a. ( ) $\operatorname{sim}($ ) não. b. Se $\underline{\text { sim }}$, quais:

11. Assinale os assuntos pelos quais você mais se interessa:

$$
\begin{aligned}
& \text { ( ) Física ( ) Cosmologia ( ) Astronomia ( ) Tecnologia ( ) Biologia } \\
& \text { ( ) Biotecnologia ( ) Ecologia ( ) História ( ) Arqueologia ( ) Neurociência }
\end{aligned}
$$

12. Qual o grau de escolaridade de seus pais?

Pai Mãe

( ) ( ) Primário ou Fundamental incompleto

( ) ( ) Fundamental completo

( ) ( ) Médio incompleto

( ) ( ) Médio completo

( ) ( ) Superior incompleto

( ) ( ) Superior completo 
( ) ( ) pós-graduação

13. Qual a profissão de seus pais?

Pai:

Mãe:

\section{SUAS CONCEPÇÕES SOBRE PROTEÍNAS}

Q.1. Diálogo extraído de uma das edições do Big Brother Brasil (BBB), exibido pela rede Globo:

JAMES no meio do furdunço da cozinha:

- Mais comida?

Juliana:

- É só macarrão. Se ninguém quiser, fica pra amanhã.

Zulu:

- Pode fazer! Macarrão é proteína! Faz bem...

a. Qual sua opinião a respeito da afirmação do Zulu - "Macarrão é proteína!'.... comente sua resposta

b. Falando em proteína, o que você entende por PROTEÍNA?

Q.2. a. Que alimentos, na sua opinião, são ricas fontes de proteínas?

b. Nessa lista de alimentos ricos em proteínas também incluem vegetais, como verduras e legumes?

c. Onde mais podemos encontrar proteínas? Relacione algumas estruturas que constituem seu corpo ou de outros organismos, como algum tipo de tecido ou secreção, que seja constituído basicamente por proteínas. 
Q.3. Observe as propagandas e reportagens a seguir:
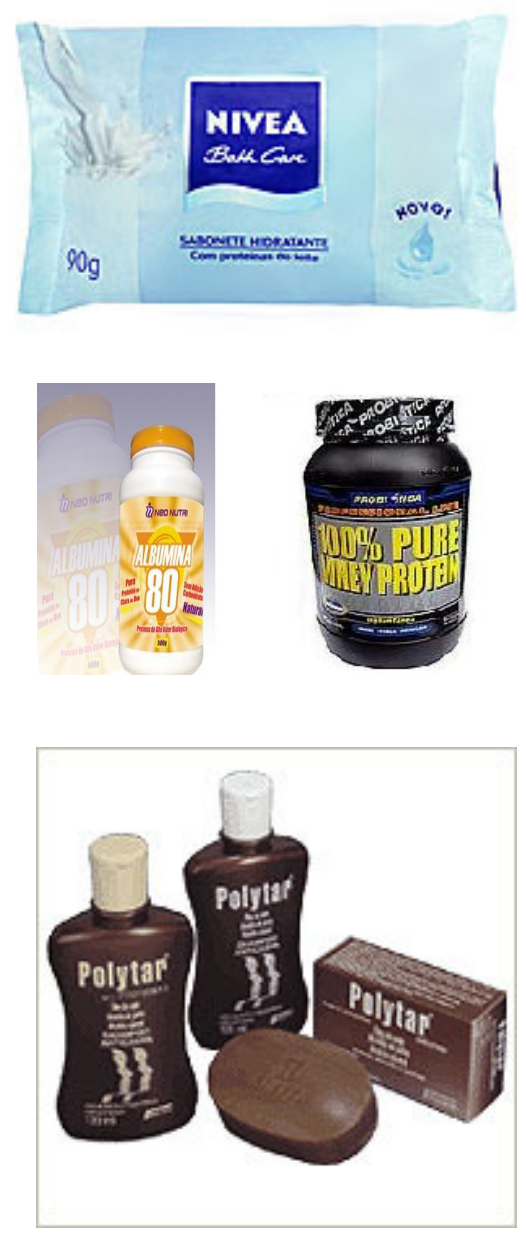

Sabonete Hidratante com Proteínas do Leite

O sabonete hidratante com proteínas do leite combina as proteínas, vitaminas e carboidratos do leite, indispensáveis ao corpo humano, que hidratam e acalmam a pele. Mantém sua pele hidratada diariamente e protege contra o ressecamento.

\begin{abstract}
Albumina 80
A Albumina 80 é um alimento em pó para preparo de bebida, constituído com a proteína da clara de ovo desidratada pura e sem adição de outros componentes.
\end{abstract}

\title{
$100 \%$ Pure Whey Protein
}

alimento composto por $100 \%$ whey protein concentrado, usado por atletas de diversas modalidades esportivas . Contém em uma dose toda a cadeia de aminoácidos essênciais para o ganho de massa magra, recuperaçâo e desempenho fisíco dos atletas.

"As crianças necessitam de proteínas extras para que possam crescer adequadamente. A necessidade média de proteínas de um bebê de quatro a seis meses é estimada em 1,4 grama por quilo de peso do corpo por dia, quase o dobro da necessidade de um adulto. Estima-se que mais do que $40 \%$ do consumo de proteínas de um bebê deve ser de aminoácidos essenciais".

Guia da Saúde Familiar - revista ISTOÉ - Volume 16 - 03/2002

"Cientistas espanhóis desenvolveram um novo tomate geneticamente modificado, de cor azul, que tem uma série de proteínas que não podem ser encontradas no tomate comum e poderia ser usado com fins terapêuticos".

Biotecnologia na saúde - BBC Brasil - 10/2006

a. A grande questão é: Por quê precisamos tanto de proteínas? Qual é o grande papel que elas exercem nos organismos?

b. Qual sua visão crítica com relação às propagandas acima? Você acha que o fato de possuírem proteínas em suas fórmulas vai surtir os efeitos propostos ou usam isso como slogan para vender mais seus produtos? Comente sua resposta. 
c. Com base nas reportagens acima, comente a respeito dos avanços da ciência com relação a Biotecnologia. Você os vê como positivos? Comente sua resposta.

Q.4. Não resta dúvida que nosso organismo precisa constantemente suprir suas necessidades de proteínas. Mas como você acha que essas proteínas serão absorvidas pelo nosso organismo? Leve em consideração que os alimentos antes de serem absorvidos passam pelo processo de digestão.

Q.5. Você acredita que nossas células sejam capazes de fabricar proteínas?

a. ( ) sim ( ) não, comente sua afirmação

b. Se $\underline{\text { sim }}$, siga com a questão...

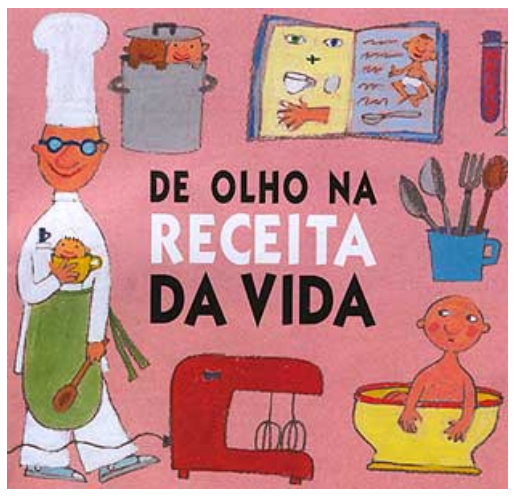

Imagine que diante dos seus olhos encontra-se um apetitoso bolo de chocolate. O bolo tem recheio, cobertura, enfeites... Enfim, deve ter dado um trabalho danado pra fazer. Agora, pense que, antes de dar uma dentada no bolo, você quer saber de onde saiu tão maravilhosa receita. Abre a gaveta da cozinha e lá está o livro de receitas. Folheando algumas páginas, você logo vê a foto do bolo, a lista de seus ingredientes e o modo de fazer, que explica a ordem em que cada ingrediente deve ser colocado para resultar naquela delícia.

Pensando agora que a célula seria a cozinha onde seu bolo (proteína) seria fabricado, responda:

O que representa a gaveta onde se encontra o livro de receitas?

O que representa o livro de receita?

O que representa a receita?

O que representa os ingredientes?

Q.6. Você saberia relacionar algumas doenças ou deficiências de que já tenha ouvido falar em que sua causa está relacionada a alguma proteína específica? Não precisa escrever a proteína, somente as doenças. 


\section{APÊNDICE E \\ ROTEIRO DA PÓS-ENTREVISTA}

Pós-entrevista

1. Baseado no jogo "sintetizando proteínas", você seria capaz de responder onde podemos encontrar proteínas em nosso organismo? O jogo ajudou a aumentar seus conhecimentos a respeito?

2. Também lembrando do jogo, qual é o grande papel que as proteínas podem exercer no nosso organismo?

3. Quais os ingredientes que a célula precisa para sintetizar uma proteína? Por quê precisamos ingerir proteínas? O jogo de alguma forma te ajudou a responder essa pergunta?

4. Com poucas palavras, descreva as etapas até formar uma proteína, lembrando das etapas do jogo.

5. Lembrando das cartas-objetivo, você conseguiria relacionar algumas deficiências relacionadas a proteínas? 


\section{APÊNDICE F \\ AUTO-AVALIAÇÃO DA ATUAÇÃO COMO TUTOR PELOS ALUNOS SELECIONADOS}
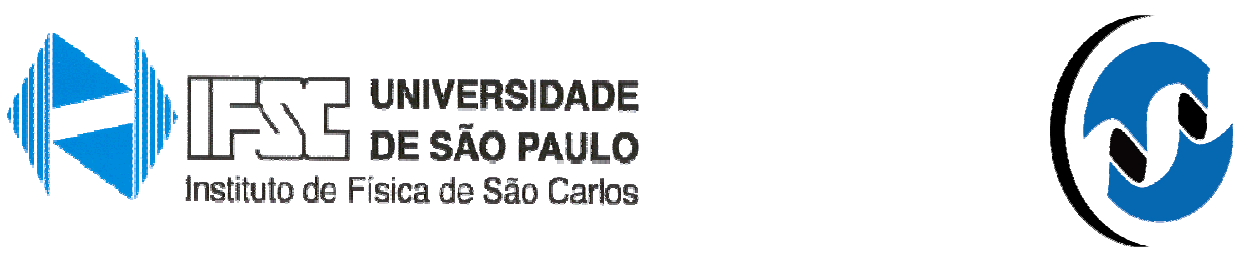

CBME

Centro de

Biotecnologia

Molecular

Estrutural

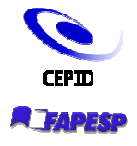

Centro de Biotecnologia Molecular Estrutural

Coordenadoria de Difusão do CBME

Nome:

Escola:

Série: período:

O que você achou de atuar como tutor na aplicação do jogo "Sintetizando Proteínas"?

Fácil, pude explicar as regras e responder as dúvidas dos colegas com clareza.

Senti dificuldade ao explicar as regras e responder as dúvidas dos meus colegas. Quais:

Outras observações que queira fazer:

Obrigado pela colaboração 
TRANSCRIÇÃO DA APLICAÇÃO DO JOGO COM A AMOSTRAGEM DO 2ª A.G.
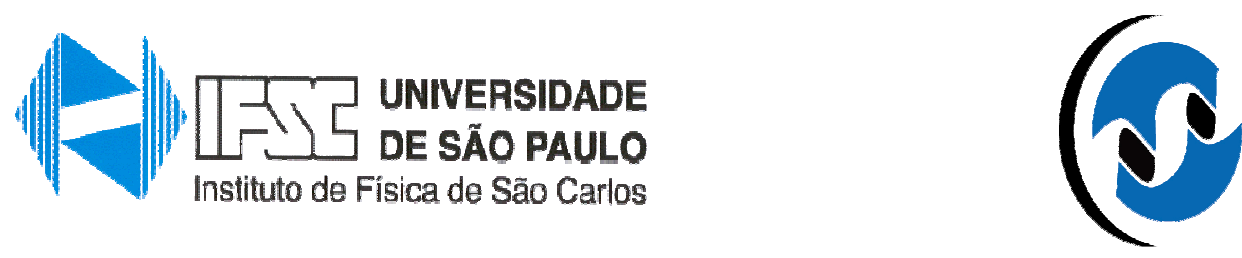

CBME

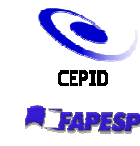

\section{Centro de Biotecnologia Molecular Estrutural}

\section{Coordenadoria de Difusão do CBME}

Escola Estadual Dr. Álvaro Guião (Turma $2^{\circ} \mathrm{G}$ )

Aplicação do jogo "Sintetizando Proteínas" com alunos entrevistados

JULIO

[0:00:05] Então vamos lá! O objetivo desse jogo, vocês já devem saber, nós vamos "passar" por todo o processo de síntese de proteínas. Se vocês prestarem atenção no material que vocês têm aí, todos têm uma carta, que a gente chama de "carta-objetivo", que o objetivo na verdade corresponde ao nome de uma proteína a ser formada. No meu caso aqui é a "actina". No caso cada um tem uma aí. Essa carta está dividida assim, tem "a situação", que a gente coloca uma situação do cotidiano que está envolvido com essa proteína. O "mecanismo" já seria o mecanismo biológico de como essa proteína atua no organismo e em baixo tem "seu objetivo", que está relacionado com o jogo, dizendo o que você tem que fazer e como conduzir a produção de sua proteína pra resolver um problema que está descrito na "situação". Porque assim, como as nossas células estão constantemente produzindo proteínas, se por algum motivo ela deixar de produzir determinada proteína, isso pode acarretar em algum problema, algum dano ao organismo, por isso que nessa "situação" a gente coloca sempre como um problema a ser resolvido.

Aí, fora essa carta vocês tem essa "tirinha aqui" (referindose a fita onde será transcrito o RNA mensageiro), que a gente vai colocar aqui, pois vamos começar no núcleo... e como que chama esse processo que a gente vai...

JAMES [0:01:39] Transcrição?

JULIO [0:01:42] Transcrição. Então o que vocês acham que representa essa "fitinha" aqui?

JAMES $\quad[0: 01: 47]$ É o... 
MAURÍCIO [0:01:48] É a cadeia de nucleotídeos do RNA.

JAMES [0:01:50] RNA

JULIO [0:01:51] Cadeia de nucleotídeos do RNA.... (apontando para os dois alunos que responderam). Qual RNA?

MAURÍCIO [0:01:58] RNA... no núcleo?

JAMES [0:01:59] RNA mensageiro?

JULIO [0:02:01] RNA mensageiro. Quer dizer que a gente vai começar aqui (apontando para o núcleo da célula), a gente vai começar com esse primeiro processo que é o de transcrição. Então esses espaços, que depois vou explicar como vai ser a dinâmica do jogo, vão ser preenchidos pelos nucleotídeos correspondentes. (referindo-me a fita do RNA mensageiro, que será preenchida com os nucleotídeos).

Estão vendo que tem uns números aqui? Significam as etapas. Então aqui, que não tem número, é a primeira etapa, que é a transcrição e num segundo momento, depois que o RNA mensageiro é feito, ele se desprende do DNA e ele sai do núcleo. Aí aqui, num segundo momento ele tem que sair, tem que atravessar essa carioteca aqui e depois num terceiro momento vai ocorrer o processo de tradução. Então essa "bolinha" aqui representa o ribossomo, então é o ribossomo que vai fazer a leitura do RNA mensageiro. Então o RNA mensageiro vai estar aqui (colocando uma das fitas de RNA no local correspondente a etapa 3)... Ta vendo que tem três? (mostrando na figura do ribossomo os espaços que representam os sítios de ligação ao RNA mensageiro) na hora da leitura aqui, em que os RNAs transportadores estarão trazendo os aminoácidos, cada três nucleotídeos no RNAm vai codificar para 1 aminoácido, não é isso, que a gente chama de trincas. Depois o ribossomo vai "andando" pela fita e a cada 3 nucleotídeos, codifica para 1 aminoácido, até ele terminar toda a leitura e vai ter formado, no caso, 5 aminoácidos. (demonstrando como seria esse processo no tabuleiro). Aí aqui você já formou sua proteína, vamos supor assim, você já tem uma seqüência de aminoácidos...

JAMES [0:03:36] Essa "fitinha" aqui? (mostrando a fita onde os alunos anotarão os aminoácidos correspondentes no processo de tradução).

JULIO [0:03:38] Isso, essa "fitinha" menor aqui. Aí formou isso aqui, formou sua proteína, isso aqui você já não utilizar mais (referindo-se a fita correspondente ao RNA mensageiro), 
JAMES [0:03:51] Aí usa essa bolinha aqui, da proteína.

JULIO [0:03:53] Aqui a proteína já ta formada.

JAMES [0:03:54] Ela vai enrolar?

JULIO $\quad[0: 03: 56] \ldots$ É, enrolar...

JAMES [0:03:57] Enovelar!

JULIO [0:04:00] Aí pra facilitar aqui, a gente colocou como sendo processar proteína, porque envolve não só enovelar, mas outros processos também. Adquirindo aqui uma forma tridimensional, porque somente essa seqüência de aminoácidos, linear, não dá a ela função. Ela só vai ser ativa depois de processada. Depois na última etapa, que é a 5", a gente chamou de "destinar proteína" por quê? É uma forma genérica de, depois que ela processou, está ativa, vai ser encaminhada onde ela vai atuar. Então pode ser que ela atue aqui na mitocôndria, pode ser que ela seja uma proteína de membrana, então ela vai ficar aqui, pode ser uma proteína que num determinado momento ela vai ficar armazenada em grânulos e depois excretada para 0 meio extra-celular... Então é nesse momento que ela vai destinar. Tudo bem?

Então seriam essas as etapas que a gente irá passar.

JAMES [0:05:01] Mas aqui seria a parte de fora da célula? (apontando para a região do tabuleiro correspondente ao meio extra-celular)

JULIO [0:05:04] Isso! É o que a gente chama de "meio-extracelular".

Aí todos esses passos, para ir do 1 até o 5 , todos eles estão descritos pelas cartas. A dinâmica que a gente faz do jogo é sempre assim: pra cada rodada a gente vai ter a possibilidade de comprar cartas, utilizar as cartas e por último descartar. Por isso que tem o descarta aqui (apontando para o tabuleiro). Pra toda rodada eu vou poder comprar, aí a gente estabelece um limite que você pode comprar até três cartas, aí você pode usar quantas puder, desde que você deixe uma para você descartar, pois toda rodada você vai ter que descartar uma.

Então por exemplo aqui ó, (apontando para o núcleo) nessa primeira etapa, que eu preciso formar o RNA mensageiro, a gente tem por exemplo... (procurando no monte de cartas que estava embaralhando)... Para iniciar lá o processo de transcrição, eu preciso de uma molécula que chama "RNA polimerase", ela que é responsável, depois 
que as fitas do DNA estão abertas, em reconhecer e encaminhar a ligação de todos os nucleotídeos.

MAURícIO [0:06:29] E ela acha onde é que está o gene?

JULIO [0:06:31] Isso!

MAURÍCIO [0:06:34] Ela desfaz as ligações hidrogenadas?

JULIO [0:06:35] Esse desfazer da hélice, quem faz é outra proteína, ela chama "helicase", mas não vem ao caso, então a gente já está partindo do pressuposto que já está aberto. Depois que o DNA se abre, a RNApol reconhece a região onde vai ser sintetizado o RNA mensageiro e vai "colocar" os nucleotídeos aqui. Ela é uma molécula que a gente chama de precursora, ela que começa. Então pra começar o jogo eu preciso ter primeiro essa daqui, "RNA polimerase", depois... isso aqui a gente vai usar uma vez só, depois do momento em que já apresentei a "RNA polimerase" aí eu posso, por exemplo, colocar nucleotídeos... aí vai ser com esse tipo de carta, ta vendo. (mostrando as cartas para eles entenderem o processo) essa aqui por exemplo tem 3 nucleotídeos, tem cartas que tem 5 nucleotídeos e eu posso, por exemplo somar. Eu tenho aqui 3 e outra com 5, posso colocar 8 nucleotídeos.

JAMES [0:07:31] Colocar 8 escritos na...

JULIO [0:07:33] Isso! A gente vai completando isso daqui. (mostrando a fita representativa do RNA mensageiro)

MAURÍCIO [0:07:35] Enquanto não completar você não...

JULIO

[0:07:38] Enquanto você não completar, você não completa essa $1^{\text {a }}$ etapa. Você só vai para a $2^{\mathrm{a}}$ etapa, quando completar aqui. $\mathrm{E}$ aqui, ta vendo que são sempre duas possibilidades? Você só pode usar duas possibilidades de cada vez? Eu tenho essa carta, se nesse primeiro momento me interessa esse aqui, que eu to colocando nucleotídeos, eu uso essa parte aqui, "ribossomo" como você vai utilizar só na $3^{\text {a }}$ etapa, você não vai utilizar, só vai utilizar uma delas. Essa é a $1^{\text {a }}$ etapa, aí eu terminei aqui, fiz o RNA mensageiro, aí eu tenho que sair, não tenho? E gente tem uma carta então chamada "atravessar a carioteca", ta vendo, só essa carta que me possibilita de pegar essa fita e trazer aqui pra fora.

MAURÍcIO [0:08:23] "Carioteca" é igual a "envelope nuclear"?

JULIO [0:08:24] É essa membrana aqui do núcleo. 
MAURÍCIO [0:08:26] É a mesma coisa?

JULIO [0:08:29] Sim, envelope você pode entender como algo que está envolvendo, fechando...

Bom, na segunda etapa é só sair. Aí a terceira, como eu vou começar a tradução, eu preciso de quem? Do ribossomo, também no mesmo "esquema" da "RNApol", eu preciso apresentar uma única vez, aí depois eu vou começar colocar aminoácidos... aí eu tenho essas cartas aqui ó (mostrando aos alunos as cartas correspondentes).

JAMES [0:09:01] Tem que completar o ciclo?

JULIO [0:09:03] Isso. Ta vendo que essas cartas já vem juntas "RNAs transportadores" e uma quantidade de aminoácidos, por exemplo com essa aqui eu coloco 3 , eu preciso colocar 5. Quando eu completar aqui eu acabei essa etapa. Aí aqui é processar proteína, que também vai ter a carta aqui ó, "processar proteína", aí eu saio dessa "fitinha" para ir para essa "bolinha" aqui. Depois de processar eu preciso destinar, que tem as carta aqui "destinar proteína". Ta bom, são essas as etapas e se no decorrer do jogo se tiver alguma dúvida, a gente vai...

MAURÍCIO [0:09:41] Dura em média quanto tempo?

JULIO [0:09:42] Em torno de 40 a 50min. É que depende muito das cartas...

JAMES [0:09:56] Não assistindo a aula de artes, ta bom. (pois com essa turma, eu apliquei o jogo no período de aula, com a autorização da professora).

JULIO [0:10:04] E aqui ó, quando chegar o momento eu vou falar pra vocês, porque eu trouxe isso aqui ó? (mostrando uma tabela com o código genético) é que quando chegar nessa parte aqui, que precisa traduzir, eu preciso converter cada trinca de nucleotídeos num aminoácido, a gente tem... vocês já viram em livros o código genético?

MAURÍCIO [0:10:22] Já.

JULIO [0:10:23] Que na verdade é uma tabelinha, mas que eu fiz de uma outra forma. Então você começa daqui do centro pra cá.

JAMES $\quad[0: 10: 36]$ A C U, por exemplo

JULIO [0:10:37] A C U, então eu vou A $-C-U$, Thr, que é a Treonina. (mostrando como utilizar o código genético) 
JAMES $\quad[0: 10: 46]$ melhor que o do livro.

JULIO

[0:10:50] $A-U-G$, aí venho aqui e vejo, "met", de metionina e assim você vai até completar aqui.

Vamos lá! Eu já embaralhei aqui... Pra essa primeira rodada não vai ter compra...

MAURÍCIO [0:12:38] E como que é, horário, anti-horário... ímpar/par...

JULIO $\quad[0: 12: 40]$ Tanto faz.

JAMES $\quad[0: 12: 46]$ Os outros podem ver nossa carta?

JULIO [0:12:47] Não tem problema.

MICHAEL [0:12:55] As cartas que usa vão ser descartas, como é que é?

JULIO [0:12:56] As cartas que a gente utilizar no jogo vamos colocar aqui embaixo (do monte de compras) e carta que for descartada aqui do lado. (monte de descarte)

Então eu posso começar que daí eu vou mostrando pra vocês. Então lembrando que na primeira etapa a gente precisa de...

MICHAEL $\quad[0: 13: 13]$ Nucleotídeos...

1 a rodada

JULIO [0:13:14] É, mas primeiro a "RNA polimerase" e depois "nucleotídeos". Vamos ver se eu tenho... por exemplo ó, eu tenho a carta "RNA polimerase" e nucleotídeos... eu posso associar essa aqui ó, tenho 5 nucleotídeos e essa outra carta com mais 5, então eu já posso colocar 10 nucleotídeos e essa aqui depois eu descarto.

JAMES $\quad[0: 13: 41]$ O que é RNAse?

JULIO [0:13:42] Ta faltando a sua fita aqui (pegando a fita do JAMES e colocando lá no núcleo juntamente com as outras dos outros jogadores) ... Então tinha a RNA polimerase, coloquei 10 nucleotídeos e vou descartar essa...

JAMES $\quad[0: 13: 54]$ O que é RNAse?

JULIO [0:13:56] Ah, esqueci de explicar... tem duas cartinhas aí que são cartinhas "coringa" vamos dizer assim, que são cartas que você pode associar para "sacanear" o colega. Então... 


\begin{abstract}
JAMES [0:14:11] Que ótimo!!!
JULIO [0:14:12] São duas, que são duas moléculas que existem. Uma delas chama "RNAse" e a outra chama "Protease", sempre quando tem esse "ASE" no final, em biologia, está sempre associada com tipos de moléculas que podem quebrar outras moléculas. Então por exemplo, se é RNAse, ela vai quebrar que tipo de molécula?
\end{abstract}

JAMES $\quad[0: 14: 31]$ RNA

JULIO [0:14:32] RNA, no caso, RNA mensageiro. Então como a gente vai simbolizar essa quebra aqui? Vai simbolizar apagando metade do que já havia sido feito, como uma forma de padronizar. Então quem já fez, no meu caso que vou colocar 10 aqui, aí se você apresentar a carta pra mim eu apago 5 e fico só com 5 . E a protease é quando já... a molécula saiu daqui (núcleo), já não vale mais a RNAse, daí ela ta aqui fora, quando tiver formando a proteína, colocando essa seqüência de aminoácidos...

JAMES [0:15:12] Pode usar essa também...

JULIO [0:15:14] Aí se a pessoa apresentar a carta "Protease", a pessoa apaga metade do que já fez.

Mas também não tem muitas dessas cartas por aí. Não precisa se preocupar tanto.

Então vamos lá!! Vou colocar aqui... O meu é o azul, vou colocando de acordo com a correspondência... "T" é "A", "A" é "U", "C" é "G"... (fui colocando os nucleotídeos e eles me ajudavam)

JAMES $\quad[0: 16: 05]$ Ah, já colocou 10...

JULIO [0:16:08] Então, por exemplo, o que eu podia fazer eu já fiz, aí essas três cartas que eu usei eu coloco embaixo do monte e agora vou ter que descartar uma.

JAMES $\quad[0: 16: 17]$ Só uma coisa assim...

JULIO [0:16:21] Descartar é esse aqui (apontando para o monte de descarte)

O descartar você acha que não é... mas o descartar que possibilita você sempre comprar carta, porque se você ficar com 5 na mão e você não usar nenhuma, na próxima rodada você não poderá comprar...

JAMES [0:16:35] Quando vou usar "processar proteína"?

TODOS [0:16:37] É a $4^{\mathrm{a}}$ etapa. 
JAMES [0:16:39] Ah, então vou usar os 5 aminoácidos.

JULIO [0:16:42] Você tem a "RNA polimerase"?

JAMES [0:16:43] Ah! Tem que ter...

JULIO [0:16:45] Você tem que ter pelo menos uma pra começar...

MAURÍCIO [0:16:46] Quantas cartas eu posso comprar?

JULIO [0:16:49] Você pode comprar até 3 cartas, mas você não pode ficar com mais de 5 na mão.

MAURÍCIO [0:16:54] Ta certo.

JULIO [0:16:56] Você não tem a carta "RNA polimerase"? (voltando-me para o JAMES)

JAMES [0:16:57] Não

JULIO [0:16:58] Então no caso você vai ter que esperar a próxima rodada. Então você vai ter que descartar uma...

JAMES [0:17:02] Ah! Eu tenho que descartar uma?

JULIO [0:17:03] Tem que descartar, porque na próxima rodada você pode comprar uma. Porque como você não pode ter mais de 5 cartas na mão, então se não tivesse esse esquema de descartar, se a pessoa não usar as cartas não poderá comprar...

JAMES [0:17:18] Agora eu pego? (referindo-se a compra de cartas)

JULIO [0:17:19] Não, só na próxima rodada.

MICHAEL [0:17:20] Sou eu?

JULIO [0:17:21] É você. Então você tem...

MICHAEL [0:17:23] RNA polimerase...

JULIO [0:17:24] Isso! E nucleotídeos?

MICHAEL $\quad[0: 17: 26]$ Três...

MAURícIO [0:17:27] Posso fazer uma coisa só por vez, é isso?

JULIO [0:17:31] Como assim? 
MAURícIO [0:17:32] Tipo, não posso... se eu tenho as cartas pra colocar todos os nucleotídeos e tiver a carta pra passar pra cá eu não posso...

JULIO [0:17:39] É, se você tiver as cartas que dão seqüência, você pode...

MAURÍCIO [0:17:41] Pode?

MAURÍCIO [0:17:43] Se eu tiver 5, 5, eu acabei a minha...

JULIO [0:17:46] Se você tiver a carta "atravessar a carioteca", você já vem pra cá, se tiver "ribossomo", já vem pra cá.

MAURÍCIO [0:17:50] Ahhh.

JULIO [0:17:51] Desde que você deixe sempre uma pra descartar.

MICHAEL [0:17:53] Seis né? (referindo-se a quantidade de nucleotídeos que poderá colocar na fita do RNA mensageiro, de acordo com suas cartas).

JULIO [0:17:54] Seis.

MICHAEL $\quad[0: 18: 00] A-U \ldots$

JULIO [0:18:05] Você está aqui ó... (corrigindo o MICHAEL que estava começando a seqüência do RNA mensageiro de trás pra frente.)

MICHAEL $\quad$ [0:18:17] A - no caso né....

JAMES $\quad[0: 18: 19] A-U-G-U-G-A$

MICHAEL [0:18:27] Seis né?

JULIO [0:18:29] Aí essas aquí... (pegando as cartas que ele havia utilizado e colocando em baixo do monte de compras).

MICHAEL $\quad[0: 18: 30]$ Tenho que descartar né...

JULIO [0:18:32] Descarta uma.

MICHAEL $\quad[0: 18: 36]$ Vou descarta essa.

JULIO [0:18:37] Essa eu vou colocar aqui. (no monte de descarte) Porque a gente põe virado aqui, porque na hora de você comprar, se te interessar alguma daqui (monte de descarte), você pode comprar daqui também ta? As vezes a pessoa sei lá, se descuidou ao descartar... 
MAURÍCIO [0:18:51] Eu tenho a RNAse, pode apagar metade dos seus nucleotídeos...

JULIO

[0:18:56] Agora eu venho aqui... (pegando o lápis-borracha para apagar metado dos nucleotídeos que já havia formado)

JAMES

[0:18:57] Ainda bem que eu ainda não fiz nenhum. Não precisa apagar, é só não...

MAURÍCIO [0:19:32] Depois que eu usei a carta eu tenho que descartar ela...

JULIO

[0:19:35] Essa aqui ela vai por último. (colocando-a em baixo do monte de compras)... Aí você tem que descartar uma. Você utilizou uma carta...

MAURÍCIO [0:19:42] Sempre que eu utilizar uma carta, tenho que descartar?

JULIO [0:19:43] Não não

JAMES $\quad$ [0:19:44] A que você usou você descarta.

JULIO [0:19:45] Não não, calma aí ó. A que você utilizou você utilizou, você não fez descarte ainda. O que você utilizou utilizou, normal.

JAMES $\quad$ [0:19:54] É como comer um doce...

JULIO [0:19:56] Você tem que descartar uma.

MAURÍCIO [0:20:12] E eu pego...

JULIO [0:20:13] Não não. É só na próxima rodada que vocês compram.

$2^{\mathrm{a}}$ rodada

JULIO [0:20:17] Então por exemplo já completou uma rodada, eu tenho só uma na mão, posso comprar 3.

JAMES [0:20:22] A ta, entendi, você sempre usa uma e descarta outra.

JULIO [0:20:26] Você pode usar quantas cartas você puder usar...

JAMES [0:20:29] Mas, depois que você usou...

JULIO [0:20:30] Desde que você deixe... por exemplo, você tem 5 cartas na mão, você tem que descartar uma, então você pode utilizar 4 cartas até, por rodada, se você puder você pode utilizar. 
JAMES [0:20:38] A ta.

JULIO [0:20:39] Então por exemplo, eu tinha uma na mão e comprei 3, ficando com 4 na mão, só não posso ter mais do que 5 tá. Bom, vamos ver, eu continuo precisando de nucleotídeos... eu tenho aqui...

JAMES [0:20:51] Pode comprar daqui? (apontando para o monte de descarte)

JULIO [0:20:53] Eu tenho aqui 3 nucleotídeos, aqui 4 nucleotídeos, então tenho 7 nucleotídeos. Então vou colocar mais 7.

JAMES [0:21:02] Ééééé.

Dá pra entender mais ou menos... (referindo-se a minha letra, que não estava bonita)

JULIO [0:21:32] Ainda bem que o DNA é perfeito, pois se dependesse de entender a minha letra pra... fazer uma proteína.

JAMES [0:21:38] Ta fazendo a proteína de repente ela sai torta... risos.

JULIO [0:21:41] Então vamos lá, eu posso utilizar duas, não necessariamente só uma. Agora descartar é uma só. Eu descarto essa daqui, essas que eu já utilizei eu coloco aqui embaixo do monte.

JAMES

[0:21:58] Agora eu compro... eu tenho que tirar o que? RNA polimerase pra começar?

JULIO [0:22:04] sim, "RNA polimerase". Se você já tiver a carta "RNA plimerase" você já pode começar e vê quantos nucleotídeos você tem...

JAMES $\quad[0: 22: 17] 5 \ldots$

JULIO [0:22:22] 5 aqui e 5 aqui ta vendo, você pode juntar e dá 10 .

Não não não... (O JAMES estava descartando as cartas que ia utilizar). O descarte é só aquela última carta que você vai descartar. As cartas que você utilizar você vai colocar aqui, embaixo do monte. Porque se você descartar essa daqui, serve pra ele, que serve pra ele... então todo mundo vai utilizar as mesmas cartas.

JAMES

[0:22:45] Ah entendi, o que descarta é só as cartas tipo "curinga"...

JULIO [ [0:22:48] Não.

MICHAEL [0:22:50] Não, o descarte é o que você descartar, não o que você usa entendeu? 
JULIO [0:22:52] Ó, espera aí...

JAMES [0:22:54] Ah o que eu uso vem pra aqui e o que eu descartei vem pra cá... (apontando para os montes de compra e descarte respectivamente).

JULIO [0:22:56] O que você usou vem aqui pra baixo e o que você não usou mas tem que descartar uma, você joga aqui.

JAMES [0:23:00] Aaaa, é que eu tinha entendido que todas as cartas eram descartadas...

JULIO

[0:23:02] Não, não, então você vai poder colocar 10 (nucleotídeos). Aí você vai falando pra ele aqui (pedindo para o MICHAEL ditar para o JAMES marcar na fita do RNA mensageiro).

MICHAEL $\quad[0: 23: 11] \mathrm{T}-\mathrm{A}-\mathrm{C} \ldots$ vai completando aí... T ...

JULIO [0:23:17] Ele vai falando a seqüência e você vai colocando a complementar...

MICHAEL $\quad[0: 23: 18] \mathrm{T}-\mathrm{A}-\mathrm{C}-\mathrm{C}-\mathrm{G}-\mathrm{T}-\mathrm{C}-\mathrm{T} \ldots 8$ não é? $\ldots \mathrm{T}-\mathrm{T}$. T não é U não...

JULIO

[0:23:45] "T" é "A", só quando for "A", que é "U"... risos. Se quiser tem borracha... Agora você só descarta uma e já pode passar pro MICHAEL.

MICHAEL [0:24:00] Tem 9, não tem? Conta aí quantos que tem... pra ter certeza.

JULIO [0:24:10] Agora é você (MICHAEL)... você pode comprar cartas.

MICHAEL [0:24:13] Tanto faz do $1^{\circ}$ ou do $2^{\circ}$ ? (apontando para os montes)

JULIO [0:24:15] Você escolhe se você quer comprar daqui ou daqui. (mostrando ao MICHAEL que ele poderia comprar tanto do monte de compras quanto do descarte).

Você começou já, ou não?

MICHAEL [0:24:40] Comecei, mas... não tenho nada... (referindo-se as cartas que havia acabado de comprar). Vou ter que descartar só. Vou descartar essa aqui... tinha duas polimerase. São duas cartas polimerase pra ele não pegar... risos. (mostrando as cartas para o JAMES e referindo-se ao MICHAEL, que ainda não havia tirado a carta "RNA polimerase")

JAMES [0:25:16] Pode escolher a carta que tiver aqui, quando for pegar? 
JULIO [0:25:18] Então é só pensar assim, é na ordem que está ai.

MAURÍCIO [0:25:20] Eu posso pegar três?... duas?

JULIO [0:25:23] Você pode pegar duas, pois você tem três.

MICHAEL [0:25:31] Você já tinha pegado a polimerase?

MAURÍCIO [0:25:32] Palhaço pera aí... risos.

JAMES [0:25:34] Ta saindo na fita vocês brigando aí sabia?

MAURÍCIO [0:25:43] nucleotídeos... 7.7 nucleotídeos. Dita pra mim...

MICHAEL $\quad[0: 25: 50]$ T $\ldots$ vai completando... A - C - G - C - T - A. Deu 7.

3ㅁodada

JULIO

[0:26:35] Essas aí são as que você usou, então vai pra baixo do monte... agora você descarta uma.

Eu posso comprar $3 . .$. é, eu preciso completar aquele negócio ali (referindo-me ao RNA mensageiro).

Eu tenho aqui... 5 nucleotídeos de RNA.

JAMES [0:27:14] Não anota 3 viu, não anota 3... Porque eu posso usar essa carta, não posso?

MICHAEL [0:27:21] Pode, só que na sua vez! É mais metade... metade de tudo. (referindo-se a carta RNAse, que pode "cortar" metade não só do que está sendo colocado, mas a metade de toda a molécula).

JAMES [0:27:27] Não, o meu é 3. Ta escrito aqui 3 RNAse.

JULIO [0:27:28] Não, Não... não sei porque está assim, mas é só RNAse e é sempre metade.

JAMES [0:27:37] A ta, essa que era minha dúvida.

JULIO [0:28:00] Vou descartar essa daqui... Vocês ficam espertos aí... risos.

JAMES [0:28:02] Aí acabou minhas cartas né, porque eu uso essas...

MICHAEL [0:28:07] Não, compra 3!!

JAMES [0:28:08] Ah, compro 3... eu tenho uma. 
JULIO

JAMES

JULIO

JAMES

JULIO

JAMES

JULIO

JAMES

JULIO

MICHAEL

JAMES

MICHAEL

JAMES

MICHAEL

JAMES

MICHAEL

JAMES

MICHAEL

JAMES

JULIO

[0:29:51] Tem que descartar uma.

MICHAEL

JULIO

MICHAEL ultrapasse 5 na mão.

[0:28:32] "Destinar proteína”...

[0:28:44] Eu tenho que jogar né?

[0:28:45] Ta certo...

[0:28:47] Onde você ta?

[0:28:48] To no C.

[0:29:00] Isso! A - A - C.

$[0: 29: 05] \mathrm{G}-\mathrm{C}-\mathrm{A} \ldots$ apagar aqui...

[0:30:22] É só uma que descarta?
[0:28:13] Você sempre pode comprar até 3, desde que não

[0:28:21] Vamos ver... 4 nucleotídeos... "atravessar a carioteca"...

[0:28:30] É, "atravessar a carioteca" é a segunda etapa.

[0:28:34] "Destinar proteína" é por último...

[0:28:39] Então eu vou usar "4nucleotídeos" e "RNAse”...

[0:28:43] Ta, então eu já vou apagando... risos.

[0:28:54] Vê se é $A-A-C$ ? (referindo-se aos últimos três nucleotídeos que ele havia colocado).

[0:29:01] Escreve aí então, G - vai completando aí...

[0:29:04] Ah "G” aí? Então espera...

[0:29:16] Eu faço confusão... deixa eu ir olhando... (preferindo ele mesmo olhar a seqüência e transcreve-la).... deixa eu

[0:29:23] Você colocou "C", não colocou? Então "A".

[0:29:27] $A-U-G-C$. Já to fazendo confusão... tem que pensar, é jogo que pensa... Eu não tenho que descartar uma?

[0:30:27] Isso, descarte é só uma... você não conseguiu?

[0:30:48] Não falei que eu sou o cara mais sortudo do mundo? 
JULIO [0:30:49] Você podia comprar quantas cartas?

MICHAEL $\quad[0: 30: 50]$ Uma.

MAURÍCIO [0:31:00] Não é 3 por vez que pode comprar, até completar 6?

MICHAEL $\quad[0: 31: 03] 3 \ldots$

JULIO [0:31:04] Pode comprar 3, desde que...

MAURÍCIO [0:31:05] Aí, só pode ter até 5.

MICHAEL [0:31:06] Toda vez que ele vai jogar ele faz essa confusão.

JAMES [0:31:09] É que ele ta querendo catar mais.

MICHAEL $\quad[0: 31: 20] \mathrm{C}-\mathrm{C}$.

JAMES [0:32:01] Não vale, o MAURÍCIO ta na frente...

JULIO [0:32:02] Não dá nada... eu já fui e já voltei duas vezes... risos. (referindo-me ao fato de ter recebido a carta RNAse por duas vezes).

JAMES [0:32:06] Já dava pra acabar né...

JULIO [0:32:12] Tem que descartar uma... Olha o cara ó... to vendo que eu não vou sair daqui ó. Já tive duas RNAse aqui, agora ele tem uma protease... risos.

JAMES [0:32:22] Ah, ele tem a protease? Mas também, não vai adiantar...

MICHAEL [0:32:26] Vai adiantar se alguém conseguir sair né... risos.

4. Rodada

JULIO [0:32:30] Como eu tenho 2 cartas, posso comprar 3 né... to no limite aqui de 5 cartas. Tenho aqui 11 nucleotídeos.

Aí ó, eu não preciso necessariamente esperar uma próxima rodada pra passar pra próxima etapa, eu preciso ter carta. Só que aqui, sobrou mais 2 e necessariamente eu tenho que descartar uma, então só posso utilizar mais uma. Aí eu vou utilizar essa aqui ó, "atravessar a carioteca"... já to livre da RNAse, se tiver mais alguma... risos... e venho pra ca... e essa aqui eu tenho que descartar. Apesar que ela seria útil pra mim, pos tem ribossomo e eu poderia passar pra ca ( $3^{\underline{a}}$ etapa), mas eu tenho que descartar. Agora é você. (JAMES). 
JAMES [0:34:00] Nossa! 4 nucleotídeos... já acabei. Já tenho o transportador também...

JULIO [0:34:11] Então completa... Transportador não, você precisa ter "atravessar a carioteca"...

JAMES [0:34:14] Então, "atravessar a carioteca"...

JULIO [0:34:17] É que você falou "transportador"... risos.

MICHAEL [0:34:18] "T", então é "A" - (...) - A - T - G... porque "G"? (questionando o JAMES pelo que ele tinha colocado, pois o JAMES havia colocado "G", quando deveria colocar o complementar " $C$ ").

JAMES [0:34:48] Eu to ficando...

MICHAEL [0:34:49] Espera aí... "A" é "U”.

JAMES [0:34:50] É, isso aí eu já tinha olhado...

MICHAEL [0:34:43] E não "T".

JULIO

[0:34:54] É que quando um fala pro outro fazer, aí você não sabe se ta falando essa letra aqui...

MICHAEL $\quad[0: 34: 57]$ Não, mas...

JAMES [0:35:01] Deixa eu ir olhando que é mais fácil. Parei no "A", "U”...

JULIO $\quad$ [0:35:11] Você colocou... é "A"...

JAMES [0:35:12] Agora ta certo...

JULIO [0:35:13] Quando é "T", é "A"... você colocou "C".

JAMES $\quad$ [0:35:14] Não, é “U”...

JULIO [0:35:15] Aqui ó, quando é "A", é "U", quando é "T" é um "A", você colocou um "C".

MAURÍCIO [0:35:20] Porque aquele pedaçinho ali que vai sintetizar a proteína não é? A trinca... como a gente vai chegar aqui e escolher o que vai passar?

JULIO

[0:35:25] Ta. Então a gente precisa aqui de "ribossomo" primeiro e depois precisamos de "RNAs transportadores + aminoácidos" aí quando for passando aqui... 
JAMES [0:35:36] Aí eu já passo lá pra baixo né? (referindo-se a etapa 2)

JULIO

[0:35:37] ... é uma seqüência, então tem esses três por exemplo, $A$ - U - G, aí eu olho e vejo qual eu vou colocar aqui primeiro... aí eu passo aqui, depois mais três, $A-U-C$, no caso é o segundo aqui e assim por diante. (Explicando para o MAURÍCIO como é procedimento na terceira etapa, a tradução).

JAMES [0:35:53] Pra que que serve a RNA polimerase mesmo?

MICHAEL [0:35:56] Pra começar... e você usa uma vez só..., então olha só (momentos antes de comprar sua carta, porque como ele só pode comprar uma carta, então precisa de sorte pra encontrar o que ele precisa)... Eeee... 3 (nucleotídeos)

JAMES

[0:36:11] Já pensou se eu conseguisse uma RNAse aqui?

MICHAEL $\quad$ [0:36:13] Nossa!!!

MICHAEL $\quad[0: 36: 14]$ Que ia detonar...

MAURÍCIO [0:37:19] Eu posso pegar 3 daqui? (monte de descarte)

JULIO [0:37:20] Pode.

MAURÍCIO [0:37:25] Eu posso pegar 2 daqui (monte de descarte) e 1 daqui (monte de compra)?

JULIO [0:37:27] Aí você escolhe se quer comprar de um ou de outro.

Ou se você quiser comprar só duas não tem problema, você pode comprar até 3 , mas se não quiser...

MAURÍcIO [0:37:46] Vai MICHAEL! (pedindo para o MICHAEL ditar a seqüência de nucleotídeos pra ele).

MICHAEL [0:37:47] Onde você está? C - A... quantos são?

MAURÍCIO [0:37:54] 4

MICHAEL $\quad[0: 37: 58]$ A ...

JULIO [0:37:59] Em qual você está?

MICHAEL [0:38:02] Então, estou no de cima (apontando para a fita em que ele estava olhando a seqüência de nucleotídeos)

Você escreveu até 0 "G"... Aqui tem $G-T-T-C .$. descarta ô. 
5 rodada

JULIO

[0:39:21] O meu, pra eu passar daqui ( $2^{\underline{a}}$ etapa) pra cá (3aa etapa), eu preciso de ribossomo... e no caso, eu não tenho. Não tenho ribossomo e tenho que descartar uma...

MICHAEL $\quad$ [0:39:30] Oh que beleza!... descarta...

JAMES [0:39:33] E essa carta "destinar proteína", o que eu faço com isso?

MICHAEL [0:39:35] Você usa aqui... (apontando para a região da $5^{\text {a }}$ etapa)

JULIO [0:39:36] É a última etapa.

MICHAEL [0:39:37] É a última.

JULIO [0:39:39] Vou descartar essa aqui, estão vendo? ... fiquem espertos, quem precisa de nucleotídeos...

JAMES [0:39:44] Agora sou eu?

JULIO [0:39:45] Agora é você.

JAMES $\quad$ [0:39:47] Vou descartar essa daqui...

MICHAEL $\quad$ [0:39:48] Não, não, você não precisa descartar...

JULIO [0:39:50] Deixa ela aí, primeiro você compra primeiro e o descarte você deixa como última...

JAMES $\quad$ [0:40:01] "Protease"... catei uma protease...

JULIO [0:40:02] Esses que são os problemas...

MICHAEL $\quad[0: 40: 03]$ Só pra ajudar...

MAURÍCIO [0:40:06] O que é "Protease"?

JULIO [0:40:07] Então, é que nem eu expliquei lá, aquelas duas moléculas, a RNAse e a Protease...

JAMES [0:40:10] A RNAse é transportadora de amino...

JULIO [0:40:13] "ASE" é "que quebra", e protease, quer dizer que ela vai quebrar proteína... então ela vai quebrar a seqüência de aminoácidos formados na 3aㅗ etapa.

JAMES [0:40:18] E "processar proteína"?... ah, é só no final...

JULIO [0:40:20] É a 4ª etapa.

Você não tem ribossomo não? 
JAMES

balançou a cabeça em sinal de negação

MICHAEL [0:40:26] Então descarta.

JULIO [0:40:27] Então você tem que descartar... descarta uma.

MICHAEL $\quad[0: 40: 30]$ Descarta uma que tem nucleotídeo...

JULIO [0:40:32] Você precisa de nucleotídeos... tem duas cartas aí... (me referindo ao monte de descarte, pois tanto eu quanto o JAMES havíamos descartado cartas que continham nucleotídeos).

JAMES [0:40:35] 5 de RNA... ajudei você em MICHAEL, R\$ 5,00.

MICHAEL $\quad$ 0:40:38] Olha! 10... olha 10 nucleotídeos!!!

JULIO [0:42:11] Não tem nucleotídeos?... então descarta uma e espera. (voltando-me para o MAURÍCIO).

MICHAEL $\quad[0: 42: 17]$ Não descarta ribossomo... não descarta ribossomo...

JAMES [0:42:21] É, não descarta ribossomo na vez dele... (referindo-se a mim, pois estava na $2^{a}$ etapa e precisava adquirir ribossomo para poder ir para a $3^{\underline{a}}$ etapa).

JULIO [0:42:23] Pode descartar, fique à vontade... risos.

JAMES [0:42:25] Só na minha.

MICHAEL $\quad$ [0:42:27] Aí, descartou...

JULIO [0:42:28] É que ele não ta ligado...

JAMES [0:42:32] Você descartou ribossomo? Ele vai passar pra próxima e ganhar de você seu bobo...

MAURÍcIO [0:42:36] Ah, eu tinha pensado em mim...

JULIO [0:42:38] Eu vou fazer o seguinte ó: vou comprar 3. Eu preciso de ribossomo, então eu já posso passar pra cá (3aㅡ etapa). Aí eu tenho aqui, 2 mais 2 são $4 \ldots$ na verdade eu já tinha 4 aqui. Teria a possibilidade de colocar 6 , mas vou colocar 5 (referindo-me ao número de nucleotídeos que colocaria na $3^{\underline{a}}$ etapa).

Então vamos lá. Aqui ó, é para eu colocar... esquema das trincas... AUG... 
MICHAEL [0:43:49] Você pega a pequenininha né? (referindo-se a fita onde os aminoácidos, frutos do processo de tradução do RNA mensageiro serão escritos).

JULIO

[0:43:53] Isso, a pequenininha. Vamos lá, "AUG", é "MET", de metionina.

JAMES [0:43:58] Tem que escrever "met"?

JULIO [0:44:00] É só escrever "MET" aqui ó. Aí, do "AUG" vou para outra trinca, "AUC", então "AUC" é "ILE", que é de Isoleucina.

MICHAEL $\quad$ [0:44:18] Você lembra tudo...

JULIO

[0:44:19] É que algumas eu gravei. "UGU", "UGU" é "CYS", de Cysteína. "AAC", "AAC" é "ASN", de asparagina. "ACA", "ACA" é treonina. Aí vocês podem pensar, tem mais uma trinca aqui e não tem mais espaço na fita. Porque a gente vem aqui ó, "UAG"... "UAG" é "fim". Então tem algumas trincas que codificam pra... elas são sinais, que a gente chama... elas codificam pra terminar, que "diz" pro ribossomo e pra RNA polimerase que "acabou", aí o ribossomo vai "desacoplar".

Aí eu posso utilizar mais uma carta... esse processo depois da tradução...

MICHAEL $\quad$ [0:45:32] Processar proteína.

6⿳亠口了 rodada

JULIO

[0:45:34] Processar né... então, eu tenha aqui... "processar proteína". E essa aqui vou ter que descartar.

MICHAEL [0:45:40] No seu caso só falta "destinar proteína"?

JULIO [0:45:41] Isso.

JAMES [0:45:47] A aparência dessa peça é de um "P"... isso é proposital?

JULIO [0:45:50] É porque é um "P" de proteína, mais processada. (O desenho da peça corresponde a um " $P$ " representado numa forma espiralada). E aqui a última etapa é "destinar proteína".

MICHAEL [0:46:00] Descarta nucleotídeo...

JAMES [0:46:02] Já posso descartar uma...

MICHAEL [0:46:06] Você já sabe o que você vai usar? 
JAMES [0:46:07] Não, é que essa eu já ia utilizar faz tempo.

JULIO [0:46:08] Ele tem tudo já na cabeça...

JAMES [0:46:11] Ribossomo, aí com o ribossomo passa...

JULIO [0:46:13] Isso, com o ribossomo você já pode passar pra cá (3 etapa). Você tem a carta ribossomo?

JAMES [0:46:17] Ribossomo, e tenho 4 aminoácidos. É isso, não é?

JULIO [0:46:26] Isso! Aí você já pode colocar 4. Código na mão!

JAMES [0:46:31] E tem mais 4 RNA transportador!

JULIO [0:46:32] Então você já pode completar os cinco aqui também...

JAMES [0:46:37] “Processar proteína”... também tenho. É só ir pra frente

JULIO [0:46:40] Então põe aqui... mas vamos... pra você aprender a colocar. (mesmo o JAMES tendo completado e já ter carta para prosseguir para a próxima etapa, pedi para que ele pegasse o código genético e colocasse os aminoácidos correspondentes na fita antes de passar para a próxima etapa).

Vamos lá... o primeiro aqui é $A U G$, qual que é $A U G$ aí?

JAMES [0:46:55] AUG... MET.

JULIO [0:47:03] Você vê que isso também é proposital, ta vendo... todo mundo começa com "AUG", e se você for ver no código aqui ó, em cima do "AUG" está escrito "início". Então essa seqüência "AUG" significa pro ribossomo que ele vai se ligar e o processo de tradução vai ser iniciado. Só começa nessa seqüência.

O próximo é "GCA"

JAMES [0:47:33] Alanina... quer dizer não sei... "Ala"

JULIO [0:47:38] Ta certo. "GAA"

JAMES [0:47:45] "Glu"

JULIO [0:47:46] Glutamato. "CCU"

JAMES [0:47:53] "Pro"

JULIO [0:47:54] Prolina. "CGA" 
JAMES [0:47:59] "Arg"

JULIO [0:48:02] Arginina. Aí, "UAG" que é o de terminar...

JAMES [0:48:09] Já foi... não cabe!

JULIO $\quad$ [0:48:10] Pode deixar aí... esse outro é o de fim.

JAMES [ [0:48:13] Já acabou já...

JULIO [0:48:15] Agora você tem que descartar uma, não tem jeito.

MICHAEL [0:49:40] Vou descartar essa... Aqui eu escrevo 3 nucleotídeos (mostrando a carta e escrevendo na fita do RNA mensageiro). "Atravessar a carioteca", "Ribossomo" e 4 aminoácidos. Vou escreve 4.

JAMES $\quad[0: 50: 22]$ Xi MAURÍCIO, só você ta perdendo...

MICHAEL [0:50:23] Eu ajudei ele, mas ele não quis...

"AUG"... é "Met", "Lys", "Glu", "lle"... terminei.

Pega 3 aí... quanto falta pra você sair? (incentivando o MAURÍCIO a terminar o RNA mensageiro dele e sair do núcleo).

MAURÍCIO [0:51:58] Só os últimos... Fala aí...

MICHAEL [0:52:02] Falta só os três últimos né?

MAURÍCIO [0:52:03] É.

MICHAEL $\quad$ 0:52:04] "ACT". U - G - A. Você tem que ter "atravessar"...

MAURÍCIO [0:52:15] Eu tenho...

MICHAEL $\quad$ [0:52:16] Você tem "atravessar"? Que menino esperto...

JAMES [0:52:20] Olha, todo mundo atravessando...

MAURÍCIO [0:52:21] "Atravessar a carioteca", "processar proteína"... não posso usar? Os dois não posso usar?

MICHAEL $\quad[0: 52: 24]$ Não.

JULIO [0:52:26] Como é que é?

MAURÍCIO [0:52:27] Os dois numa carta só... não posso usar?

JULIO [0:52:28] Ou um, ou outro. 


\begin{abstract}
MAURÍCIO [0:52:33] Deixa eu ver...
MICHAEL $\quad[0: 52: 34]$ Ribossomo...

MAURÍCIO [0:52:36] Tem que ser ribossomo? Então eu tenho.

MICHAEL [0:52:39] Isso! Beleza (colocando a fita do RNA mensageiro do MAURÍCIO no espaço correspondente a etapa 3).

Você descartou qual?... não, ele tem a "protease"!!... Ai, meu Pai...

A "protease" pode usar em qualquer lugar?

JULIO [0:53:04] Pode ser aqui ó... (apontando para a região da $3^{\underline{a}}$ etapa). No caso aqui, as nossas já estão processadas (apontando para a minha e a do JAMES, que já estávamos na $4^{\underline{a}}$ etapa e portanto, segundo a regra, fora da atuação da "protease").
\end{abstract}

JAMES [0:53:08] Usa a "protease" no MICHAEL!!!

MAURícIO [0:53:18] A seqüência é essa daqui né? "AUG" é o que começa... "AUG" início. Aí "pula" 3...

MICHAEL $\quad$ [0:53:40] Não, não... vai de 3 em 3... "AUG", agora "CGA"...

MAURÍCIO [0:53:45] Não vai "pulando" 3?

MICHAEL $\quad[0: 53: 47]$ Não...

MAURícIO [0:53:49] Você falou que ia "pulando" 3. Então como vai fazer? Codifico esses três, "pula" 3 ...

MICHAEL [0:53:59] Não!

MAURÍCIO [0:54:00] É de 3 em 3, direto. "CGA", "arg"...

JAMES [0:54:07] Ele quer ficar pulando... safado ele... E podia fazer assim: daqui pula três, e se errar não completa...

JULIO [0:54:15] Por isso que fala que a diferença de uma proteína e outra é a seqüência... "você" vai seguindo a seqüência né, mudou a seqüência, mudou a proteína.

JAMES [0:54:25] Ah, o deles é aqui então... (não havia percebido ainda que as vias de síntese de proteína podiam ser diferentes)

JULIO [0:54:26] É, porque tem assim, tem proteínas que o processo de tradução, processamento é feita aqui mesmo no citosol, outros é aqui... por isso que um dos retículos endoplasmáticos é chamado de "rugoso", porque ele tem 
um monte de ribossomos aqui ó. Então o processo de síntese ele ocorre aqui dentro... ele vai formar a proteína aqui dentro, a proteína vai passar pra cá... passa pelo complexo de golgi...

MICHAEL $\quad$ [0:54:40] É só três... Agora descarta.

JAMES [0:54:52] E essas vão ser "mandadas" pra fora da célula

JULIO [0:54:53] Isso.

JAMES [0:54:58] E essas aqui no caso vem pra cá, pra cá (apontando para as regiões do tabuleiro correspondente aos "destinos" das proteínas intra-celulares).

MAURÍCIO [0:55:00] São éxons aquilo ali?

JULIO [0:55:02] O que?

MAURÍCIO [0:55:04] Essas excretadas...

JULIO [0:55:07] Espera aí...

JAMES [0:55:11] Acha!! "Éxons" e "íntrons"... aqueles "pedaços que a professora falou"...

JULIO [0:55:16] Porque assim, você pega o gene, a seqüência de nucleotídeos lá, não são todas as seqüências que codificam pra "alguma coisa"...

JAMES [ [0:55:24] "Íntrons" joga fora... não, são os "éxons"...

JULIO [0:55:26] São os "íntrons" que... aí a célula "tira", porque não vai servir pra nada. A seqüência que você vai codificar pra proteína é a que contém os "éxons"...

MAURÍcIO [0:55:35] Não tem nada a ver com aquilo ali...

JULIO [0:55:36] Não, aquilo são proteínas que vão ser encaminhadas para os lisossomos ou ao meio extracelular, através de grânulos de secreção.

7므 rodada

JULIO [0:55:46] Sou eu né... vou comprar aqui 3... eu só preciso destinar a proteína...

MICHAEL $\quad$ [0:55:51] Tava aqui embaixo... (no monte de descarte) 
JULIO [0:55:53] Caramba, eu não vi!

JAMES [0:55:54] Tem gente que vai perdeer!!

JULIO [0:55:56] Mas eu já tenho aqui ó... então olha lá... "destinar proteína". Então essa minha proteína, ela vem pra cá. Aí eu vou ler só para vocês terem uma idéia... depois cada um vai ler o seu... no meu caso, o objetivo era formar uma proteína chamada Actina. Vocês sabem onde... vocês já ouviram falar dessa proteína? Ta sempre junta com outra proteína chamada miosina... Actina e miosina. (ninguém se manifestou, somente balançavam a cabeça em sinal de negação). É no músculo... no mecanismo de contração. (Passei então a leitura da carta-objetivo)

Ta vendo que ela vai ficar no citosol, da célula muscular, e aí quanto mais miofibrilas tiver, mais massa muscular o indivíduo terá. Por isso que a gente brinca que as pessoas que fazem musculação ficam "bombados"... Então esse que era o meu objetivo. Vocês querem ler o objetivo de cada um?

MAURÍCIO [0:57:58] Eu já li o meu.

A partir desse momento cada um leu seu objetivo em voz alta, para discutirmos ao final

MICHAEL [0:58:00] Sintetizar um molécula de "pró-insulina" num grânulo de secreção, para que após a alimentação, seja transformada em insulina e liberada. A minha ficaria aqui... (apontando para o grânulo de secreção)

JULIO [0:58:12] No caso ficaria aqui né... o seu era o da insulina?

MICHAEL $\quad[0: 58: 16]$ Isso, insulina

JULIO [0:58:18] Então por isso que no caso da diabete... quem tem problema de diabete, é que o organismo não consegue produzir essa proteína aí, insulina. Por isso que a pessoa tem que "injetar" insulina todo dia, porque o organismo não consegue. O seu qual que é? (JAMES)

JAMES [0:58:35] O meu é queratina. "Para criar uma barreira de proteção da sua pele, você precisa produzir uma molécula de queratina e destina-la ao citosol".

JULIO [0:58:45] O que é a queratina? Onde ela está?

JAMES $\quad[0: 58: 48]$ Queratina? Ta no cabelo, na pele... 
JULIO

[0:58:45] Seria essa primeira camada da nossa pele... certinho? Entenderam, gostaram... o que vocês acharam?

MICHAEL $\quad$ [0:59:47] Interessante o jogo... engraçado.

JAMES

[0:59:55] É, eu achei normal... pra mim eu achei normal, porque eu não gosto muito de jogo assim.

MAURÍcIO [1:00:02] Só com cerveja, num churrasco assim... Chamar os amigos... ô vamos brincar de sintetizar proteína?

JAMES

[1:00:06] Nossa! Você acaba com o churrasco.

MAURÍCIO [1:00:09] Já pensou se um dia a gente chegasse assim?

JAMES

[1:00:11] Você acaba com o churrasco, não vem ninguém.

JULIO

[1:00:14] E com relação ao processo de produção da proteína? Entenderam?

JAMES [1:00:21] Isso eu já sabia.

MICHAEL [1:00:22] AAA, eu não sabia não... risos. Eu não sabia, deu pra aprender um pouco.

JULIO

[1:00:25] As etapas todas aqui, deu pra entender? Lembrar?

MICHAEL

[1:00:29] É, ficou mais detalhado né... A polimerase, acho que nenhum de nós três sabia...

JAMES [1:00:32] Ah sim, acho que na minha opinião, vendo você consegue imaginar melhor, entendeu? Por exemplo, sai de lá, vem pra cá, a gente vai acompanhando... bem melhor.

JULIO

[1:00:50] Quer dizer que uma coisa é você aprender os conceitos separados - O que é transcrição? O que é tradução?...

MICHAEL $\quad[1: 00: 56]$ Agora que eu entendi os processos... risos.

MAURÍCIO [1:00:57] Agora, que nem "complexo de golgi", "retículo rugoso", esses assim...

JAMES [1:01:04] Você nunca viu?

MAURÍCIO [1:01:05] Vi sim, mas o que que é?

MICHAEL $\quad[1: 01: 06]$ Você tinha que aprender isso no $1^{\circ}$ ano... risos.

MAURÍCIO [1:01:12] É sério!!! Meu professor do 1ํano vou dizer pra você viu... 
MICHAEL [1:01:14] Um dos últimos seminários que fui apresentar, todos do meu grupo faltaram e não tinha nem o trabalho escrito, só tinha um rascunho na mão e tinha que falar sobre retículo endoplasmático e ribossomo...

JULIO [1:01:25] Tem algumas funções gerais, como vocês podem ver que ele tem uma série de canais, então serve, entre outras coisas, como transporte de substâncias do núcleo para outras organelas... No caso do R.E.R, os ribossomos na superfície são responsáveis pelo processo de síntese de proteínas... no complexo de golgi, entre outras coisas, ocorrerá o processamento de algumas proteínas, as mitocôndrias...

MICHAEL [1:02:47] São as bombas energéticas.

Fim da transmissão... 


\section{APÊNDICE H}

TRANSCRIÇÃO DA APLICAÇÃO DO JOGO COM A AMOSTRAGEM DO 2B EDUCATIVA
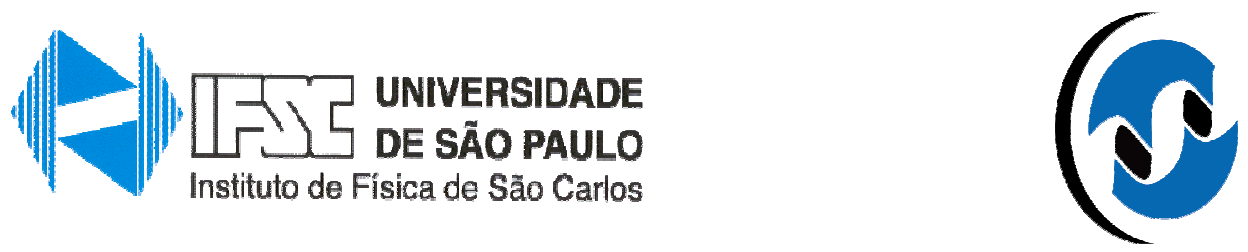

CBME

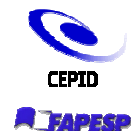

Centro de Biotecnologia Molecular Estrutural

Coordenadoria de Difusão do CBME

Colégio Educativa (Turma $2^{\circ} \mathrm{B}$ )

Aplicação do jogo "Sintetizando Proteínas" com alunos entrevistados

Obs. Os primeiros cinco minutos e vinte e dois segundos da gravação não puderam ser transcritos por ocasião de ruídos oriundos de conversas paralelas terem sido captados pela câmera. O fato de esses ruídos serem de conversas, uma filtragem pela freqüência não foi possível pela similaridade entre esses ruídos e o diálogo com os alunos durante o jogo.

JULIO [0:05:22] ... Agora para iniciar eu preciso da carta... dessa aqui ó...

GUTO [0:05:25] Polimerase.

JULIO [0:05:27] RNA polimerase. Eu preciso dela para iniciar, porque enquanto eu não tiver essa carta... porque tipo assim, eu distribuo as cartas, vocês podem ter no máximo cinco cartas na mão e cada rodada você vai ter direito de comprar até três cartas e no final de cada rodada você é obrigado a descartar uma carta.

O descartar... está ali o descarte (apontando para a região do tabuleiro destinada para o descarte). E o descartar eu descarto com a carta virada para cima.

PRISCILA [0:05:58] Eu posso comprar a carta que foi descartada?

JULIO [0:05:59] É, se o próximo jogador ele quiser... ele pode comprar três cartas... ele pode comprar três cartas tanto do monte de compras como do descarte.

BRENO [0:06:09] Agora tem como eu comprar umas do monte de compras e outras do descarte? 
JULIO

PRISCILA

JULIO

TODOS

JULIO

PAULO
[0:06:14] Pra via de regra a gente padronizou assim, ou você compra do monte de compras ou você compra do descarte. Então, como eu tentei mais ou menos passar é que você pode ter no máximo cinco cartas. Vamos supor que em uma rodada você está com três cartas na mão...

[0:06:29] Você só pode comprar duas.

[0:06:31] Você só pode comprar duas, porque não pode exceder cinco cartas na mão.

Pensa! Toda rodada vai ser essa dinâmica: compro carta, jogo e descarto. E a jogada vai ser o que? Você trocar as cartas pelos elementos que necessitar naquela rodada. Então só pra a gente entender aqui as etapas, na primeira aqui, que é a transcrição o que a gente precisa? Da RNA polimerase, então eu preciso ter a carta "RNA polimerase". Enquanto você não adquirir a carta "RNA polimerase", você ficar parado e os demais jogadores jogam normal. Adquiriu a carta "RNA polimerase", então você já iniciou, que está representado por esses quadradinhos coloridos (apontando para as fitas que representam o RNA mensageiro que os alunos formarão, em que a RNA polimerase está representada por um quadradinho colorido no início da cadeia). Então você já pode iniciar. Iniciou você precisa do que? Dessas cartas de nucleotídeos. Então você só vai evoluir no jogo quando você tiver essas cartas de nucleotídeos para ir colocando. Então se você tiver outras cartas como "atravessar carioteca", "processar proteína", vão ser outras etapas, agora você precisam de nucleotídeos. Terminou essa parte aqui, em que você vai sintetizar seu RNA mensageiro, aí eu preciso o que? A próxima etapa... esse RNA mensageiro vai continuar aqui no núcleo?

[0:07:38] Não.

[0:07:39] Não tem função nenhuma ele ficar aqui dentro, ele precisa o que? Ele precisa sair. Aí para ele sai ele precisa atravessar essa membrana que a gente chama de carioteca. É por isso que tem essa carta aqui "atravessar a carioteca". Vocês estão vendo que todas as etapas estão descritas nas cartas. A dinâmica do jogo ela vai se dar somente pelas cartas... compra, descarte... Aí tem duas cartas aqui, que a gente fala que são "carta sacanagem", que foi uma forma de a gente criar uma forma dinâmica para o jogo... que são duas cartas... 
JULIO [0:08:19] Dá trabalho!

PAULO [0:08:21] É? Eles destroem o RNA?

JULIO [0:08:22] Isso! É basicamente isso daí.

PAULO [0:08:24] Cara! Isso vai ser zaz!... nós vamos pegar as duas (voltando-se para o seu parceiro).

JUNIOR [0:08:27] Achei que eu fosse fugir desse tipo de jogo... É o "RNA faca"... risos (voltando-se para a PRISCILA, a KÁTIA e o BRENO, que também riram).

JULIO

[0:08:30] Porque assim, são coisas que existem na natureza... tem uma molécula que chama RNAse, então tem algumas proteínas em que a principal função delas é quebrar algumas moléculas. Essa RNAse quebra basicamente RNA. Então no nosso jogo, enquanto o jogador está aqui no núcleo, onde ele está formando o RNA mensageiro, se alguém tiver uma carta que chama RNAse, aí você pode escolher um dos jogadores, apresenta a carta e ele vai ter que fazer o que? Apagar metade do que ele já tiver feito.

TODOS

[0:09:03] $\mathrm{N}-\mathrm{O}-\mathrm{O}-\mathrm{O}-\mathrm{O}-\mathrm{O}-\mathrm{S}-\mathrm{A} ! ! ! ! ! ! !$

JULIO

[0:09:04] Foi a forma que a gente padronizou, é lógico que a RNAse na natureza, ela corta "aonde ela quiser" (não entrei em detalhes do tipo: especificidade das RNAses), mas a gente vai padronizar sempre a metade. Aí ta, você saiu aqui, já vai começar o processo de...

BRENO [0:09:19] Então essa carta "RNAse" só pode usar no núcleo?

JULIO

[0:09:24] Só usa dentro do núcleo! O RNA saiu do núcleo, já não vale mais aquela carta. Aí ele está imune, vamos dizer assim.

KÁTIA [0:09:30] Tem outra?

JULIO [0:09:32] Tem outra, mas é aqui (apontando para a região do tabuleiro correspondente a etapa 3 (tradução). Aí aqui ó, seu RNA mensageiro vai começar outro processo, que é o que? Tradução, né gente? (todos acenaram com a cabeça em sinal positivo). Que é onde realmente vai ocorrer o processo de síntese de proteína. Então estão vendo esse "bichinho" aqui? (apontando para a figura do ribossomo no tabuleiro) te lembra alguma coisa?

PAULO [0:09:50] Ribossomo 
JULIO

PAULO

JULIO

PAULO

JULIO

JUNIOR

JULIO

PRISCILA

JULIO

JULIO
[0:09:51] Ribossomo né gente? Então essa estrutura aqui se junta ao RNA mensageiro. O ribossomo vai começar a fazer 0 que? A leitura do RNA mensageiro, ta? E aqui vai funcionar o que? Qual outro tipo de RNA que vai ajudar o ribossomo na produção da proteína?

\section{[0:10:11] RNA transportador?}

[0:10:12] RNA transportador. Qual a função do RNA Transportador?

[0:10:15] Trazer os aminoácidos.

[0:10:17] Trazer os aminoácidos.

[0:10:20] Voltando-se para a KÁTIA, disse algo do tipo: Sabe tudo! E ela riu.

[0:10:21] A gente sabe que aqui ó que a cada trinca, que é um códon, vai ter um aminoácido que tem uma seqüência de três, o anti-códon, que vai encaixar aqui. Então a gente precisa do que? Do RNA transportador e de aminoácidos, certo? Aí passou dessa etapa aqui, já vai...

[0:11:00] Só tem cinco aminoácidos?

[0:11:05] Isso, porque a cada três nucleotídeos você vai ter um aminoácido correspondente. Quer dizer que nessa seqüência todinha, essa vai ser a seqüência de aminoácidos (mostrando a outra fita que eles terão que usar na etapa 3, correspondente aos aminoácidos). É menorzinha justamente porque a cada três, você tem um aminoácido. A gente vai representar só com um "a" porque eu esqueci de trazer um código que a gente consegue relacionar os três nucleotídeos e saber qual o aminoácido correspondente, que tem entorno de 20 , mas como eu não trouxe agora a gente vai representar assim: cada vez que você trocar cartas, você coloca um "a" aqui. Aí terminou aqui, você já vai ter formado sua proteína, mas ela é basicamente só uma cadeia solta. Aí ela precisa passar por um outro processo...

\section{PRISCILA [0:12:11] Aí você não vai mais usar essa fita? (RNA mensageiro)}

[0:12:14] Isso, aí você não precisa mais desse, só desse. Aí depois você tem um outro processo que é assim, você tem a proteína, só que apenas uma cadeia de aminoácidos, só que para ela ter função dentro da célula, pra ela exercer a função para a qual ela foi criada, elas não vai estar solta assim, simplesmente uma cadeia de aminoácidos, ela vai 
se torcer toda, vai se enovelar, que a gente chama, para dar uma forma e essa forma é que vai dar a função para a proteína. A gente simplificou para apenas "processar proteína". Tem uma carta que está escrito "processar proteína", aí você passa... sai dessa forma linear aqui para essa aqui. Então ela já está processada e a última etapa é "destinar proteína", por quê destinar proteína? Porque a gente não tem um tipo só de proteína, temos proteínas de membrana, temos algumas proteínas que estão soltas (citosol), outras saem como é o caso da hemoglobina, que carreia o oxigênio na corrente sangüínea. Outras proteínas podem ficar na mitocôndria, outras voltam para o núcleo. Então essa última etapa seria esse "destinar proteínas".

PRISCILA [0:13:56] Dessa parte pra frente não entendi nada (apontando para a região do tabuleiro correspondente a etapa 4)

JULIO [0:13:58] Então depende do tipo de proteína. Quando você processa, ela vai estar aqui, onde está esses "p" e quando você vai destinar proteína você já vai para essas outras regiões aqui.

\section{PRISCILA $\quad$ [0:14:11] E esse número aqui? (Apontando ainda para a etapa 4)}

JULIO

[0:14:13] É que essa aqui é só o número das etapas. A etapa 1 é aqui dentro (núcleo), etapa 2 aqui fora (citosol), etapa 3 aqui com o ribossomo, etapa 4 "processar proteína" e etapa 5 "destinar proteína”, última etapa.

Aí o que que a gente tem, bom, vocês vão formar proteínas, mas aí vocês perguntam: que proteína iremos formar? Não sei? A gente fez o seguinte, tem quatro proteínas aqui. Na verdade esse jogo possui 16 tipos de proteínas diferentes, assim cada vez que você jogar, você pode mudar. Dando seqüência aqui, para a gente começar, cada um pode escolher. Vocês? (Voltando-me para a dupla JUNIOR e BRENO)

FERN./BRENO [0:15:01] Amarelo

JULIO [0:15:04] Então o de vocês é esse aqui. O objetivo é o nome da proteína que vocês vão formar. Essa aqui é uma forma também de vocês aprenderem o nome de algumas proteínas, funções e tudo mais. A proteína de vocês é essa aqui, "glucagon"... não pensem besteira... Aí a gente sempre coloca uma situação, pois a proteína de alguma forma está relacionada ao cotidiano, o mecanismo, que é como essa proteína vai atuar e o seu objetivo que é a formação dessa proteína. Então aqui, essa aqui é de vocês (JUNIOR e BRENO - amarelo), essa aqui é de vocês (PRISCILA e KÁTIA - verde), essa aqui é minha (azul) e 


\section{G. AZUL [0:15:55] Adrenalina!}

TODOS [0:15:56] Oh!!!!!!

G. AZUL [0:15:57] Power!

JULIO [0:16:00] Vamos lá, qual é a situação?

G. AZUL [0:16:06] Leitura da carta-objetivo pelo PAULO.

JULIO [0:17:56] Vocês entenderam como ela vai ser utilizada, quando que você precisa dela? Que são sempre situações que requerem o que? Quando ele diz "luta e fuga", é que você precisa assim, geralmente quando você fica numa situação de excitação, o coração palpita, você fica naquela tensão, naquele nervosismo e seu corpo reage como? Se é numa situação que nem do cachorro, você quer o que? Você quer sair correndo, seu corpo precisa daquela energia, daquele gás pra sair ou no caso de situações que, sei lá...

KÁTIA [0:18:41] Montanha russa

JULIO [0:18:42] É, nesse caso seu corpo está produzindo constantemente adrenalina e você fica naquela situação de tensão. Então o objetivo dele é formar isso daqui. Quando ele fala aqui que o objetivo é formar e lançar no citosol, o citosol é aonde?

PAULO [0:18:53] Aqui fora (apontando para o meio extracelular)

JULIO [0:18:55] É aqui ó, aqui dentro.

PAULO [0:18:57] Dentro?

JULIO [0:19:00] Primeiro a adrenalina vai ficar livre aqui no citosol e toda vez que o organismo precisa, ela será mandada para a corrente sangüínea. Vocês agora (PRISCILA e KÁTIA)

G. VERDE [0:19:05] Leitura da carta-objetivo pela PRISCILA

JULIO [0:20:09] Então onde vai atuar essa proteína?

G. VERDE $\quad[0: 20: 11]$ No olho. 
JULIO

[0:20:12] Então está vendo que já tem uma proteína que está presa numa célula, então ela está espalhada pelo corpo todo. No caso dessa aqui ela está especificamente no olho. Quando você tem aquela sensação de estar num quarto escuro e de repente sua mãe chega e - paaaaaa! - você não consegue abrir o olho. Então você precisa de um tempo para você poder produzir essa proteína e poder abrir o olho. E você (JUNIOR e BRENO)

G. AMARELO [0:21:28] Leitura da carta-objetivo pelo JUNIOR.

JULIO [0:22:58] No caso aí relacionado com a alimentação. Se você não se alimenta como vai produzir energia? Ele fica armazenado em grânulos e depois ele é secretado para fora da célula.

Nesse momento a partida foi interrompida para que as alunas PRISCILA e KÁTIA pudessem telefonar. Desse momento em diante o jogo recomeçou, mas sem a presença da aluna PRISCILA, que teve que ir com seus pais embora. Portanto a aluna KÁTIA ficou sozinha no jogo.

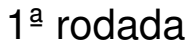

JULIO [0:23:23] Quem vai começar?

PAULO [0:23:27] Joquemmmm-po!

KÁTIA [0:23:30] Eu começo vai.

JULIO [0:23:32] Você tem a carta RNA polimerase?

KÁTIA [0:23:34] Eu tenho.

JULIO [0:23:36] Você já pode começar... abriu o jogo. Ta, o que você precisa agora? Você já tem a RNA polimerase e agora você precisa de quê?

KÁTIA [0:23:44] Eu tenho os nucleotídeos.

JULIO [0:23:45] Então você pode associar as cartas para usar.

PAULO [0:23:49] Pode usar mais de uma?

JULIO [0:23:51] Pode. Se você quiser usar as cinco, você pode usar as cinco.

PAULO [0:23:54] Nossa!!... já é!!!

JULIO [0:23:55] Quantos nucleotídeos você tem... 


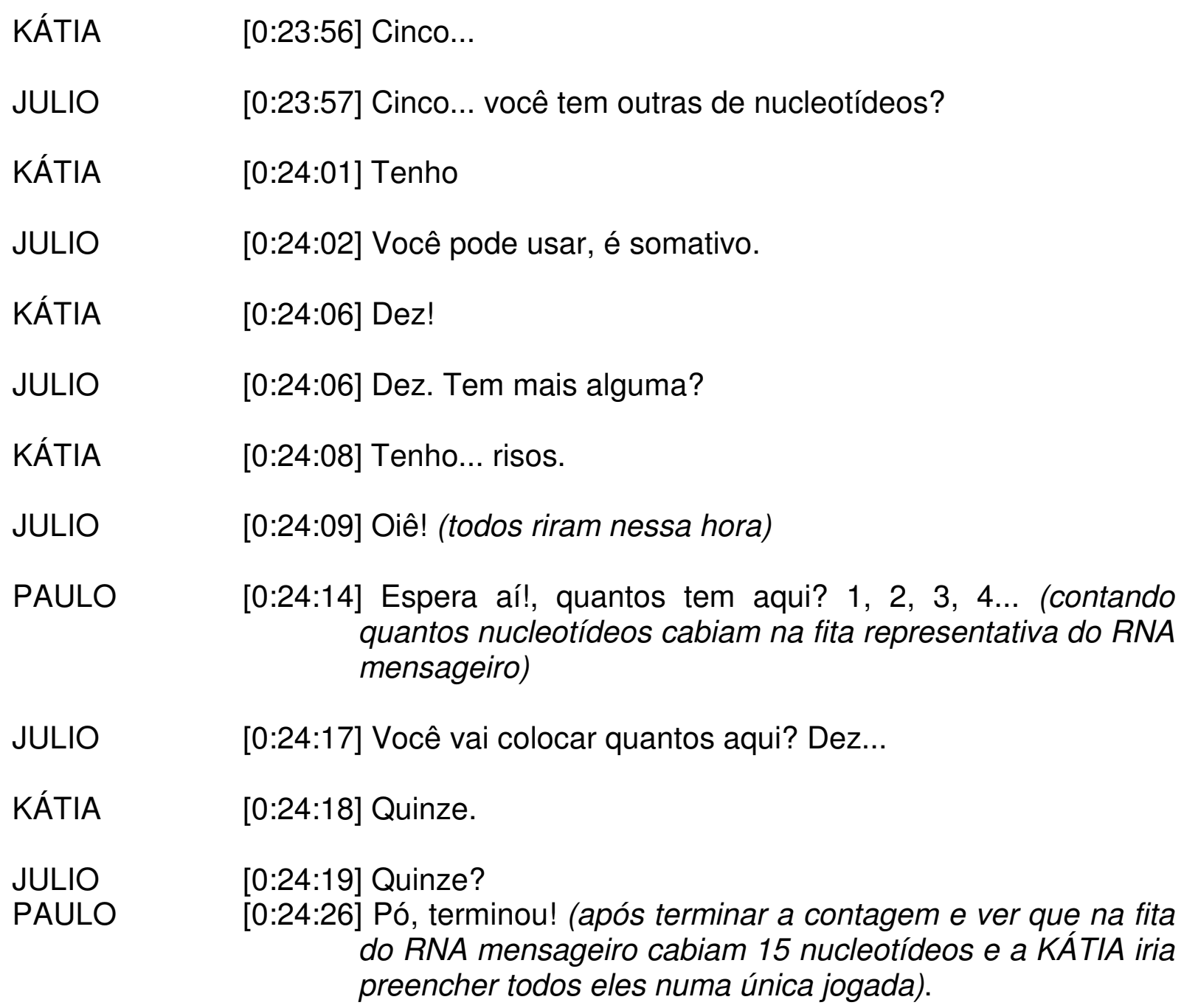

JULIO [0:24:29] Tem uns vinte... passou. Não tem problema. Mas coloca aqui, para você não esquecer. Agora você tem que lembrar... você tem que completar. Vamos lá, "T", quem complementa o "T"?
KÁTIA
[0:24:50] O "A".
JULIO
[0:24:51] Então põe. O próximo é o "A"...
KÁTIA [0:24:58] "T"
JULIO [0:24:59] “T”?
JUNIOR [0:25:00] “U”
KÁTIA [0:25:01] É verdade!
JULIO [0:25:02] Não esqueça que esse é o seu RNA mensageiro. No RNA é "U". O próximo é C ... (Eu ditava a seqüência de nucleotídeos na fita de DNA, enquanto ela formava seu RNA colocando os nucleotídeos correspondentes). 
PAULO [0:25:42] Nossa! Mais já? (referindo-se ao fato da KÁTIA já ter terminado de completar seu RNA mensageiro).

JULIO

[0:25:43] Sobrou alguma aí? Você usou todas as cartas?

KÁTIA

[0:25:46] É.

JULIO

[0:25:54] As cartas que você usou você pode colocar embaixo do monte.

PAULO [0:25:52] Nossa!, pelo amor... eu te mato! Risos. (Voltando-se para a KÁTIA, que também respondeu com risos)

JULIO

[0:25:58] As vezes acontece. Os próximos são vocês (apontando para a dupla JUNIOR e BRENO).

JUNIOR

[0:26:05] Apresenta uma carta na mesa.

JULIO

[0:26:06] Que carta você tem? RNA polimerase? Pode começar.

JUNIOR

[0:26:08] Então a gente começa! Aqui a gente tem 3 nucleotídeos, 4 e 5. A gente tem 12 nucleotídeos.

JULIO

[0:26:33] Vamos lá, começa aqui... "A"...

BRENO

[0:26:39] "A" né, “U”, "G”, “U”, não, "A”... (soletrando para o JUNIOR escrever na fita do RNA mensageiro).

JULIO

[0:26:48] É uma seqüência de quatro iguais aqui "T", "T", “T”, "T".

BRENO

[0:26:50] "A", "A", “A", “A".

KÁTIA

[0:26:51] 4 "A"

JULIO

[0:26:55] Espera aí, tem 4 com 3, sete. O próximo é um "A"...

BRENO

[0:27:00] "U”, “G”...

JUNIOR [0:27:04] BRENO, você está falando certo?

BRENO [0:27:05] “C”...

JULIO

[0:27:08] Espera aí, 3, 6, 9, esse é o décimo.

BRENO

[0:27:12] "T", não calma aí...

JUNIOR

[0:27:15] Agora é “A”...

BRENO

[0:27:15] "U" 

JULIO
[0:27:16] "A"
JUNIOR
[0:27:18] É "A"! (voltando-se para o BRENO).
BRENO
[0:27:19] Mas não é RNA?
JULIO
[0:27:20] Não "T" combina com "A", e "A" combina com "U"
BRENO
[0:27:21] Mas não é...
JULIO
[0:27:23] E "A" combina com "U"
FER/KÁTIA
[0:27:23] E "A" combina com "U".
BRENO
[0:27:24] Ah é! (balançando a cabeça de um lado para o outro, reconhecendo que havia falado errado).
PAULO [0:27:44] Podemos? (pedindo permissão para iniciar o jogo).
JULIO
[0:27:45] Vocês tem por algum acaso uma carta chamada "atravessar a carioteca"? (voltando-me para a dupla JUNIOR e BRENO)
JUNIOR [0:27:51] Não
JULIO
[0:27:52] e você tem que descartar uma, então essa última você descarta... Espera aí, essas que você usou vão para o fundo do monte e essa última aí você põe no monte de descarte virada pra cima.
JUNIOR [0:28:11] E agora compro?
JULIO [ [0:28:12] Agora não, só na próxima rodada.
PAULO [0:28:14] Qual que vamos descartar? (perguntando para o seu parceiro GUTO e o mesmo apontou uma das cartas)
Essa não podemos descartar!
JULIO [0:28:18] O descartar você tem que lembrar que o outro pode comprar
KÁTIA [0:28:19] E to aqui? (apontando para a região do tabuleiro correspondente a etapa 2).
JULIO [0:28:20] Você precisa sair daqui (do núcleo).
KÁTIA [0:28:23] Como que é !? 
JULIO

KÁTIA

JULIO

PAULO

JULIO

PAULO

JULIO

PAULO

KÁTIA

JULIO

KÁTIA

JULIO

PAULO

JUNIOR

PAULO

JULIO

PAULO

JULIO

KÁTIA

JUNIOR
[0:28:26] Como que chama isso daqui mesmo? (apontando para a carioteca)

[0:28:29] Membrana... risos.

[0:28:31] Vocês têm a RNA polimerase?

[0:28:35] Aqui. Temos mais 9... nucleotídeos.

[0:28:40] Pode começar a colocar... Vai ditando pra ele aí... risos (voltando-me para o PAULO, que ia ditar para o parceiro a sequência correspondente, de nucleotídeos do RNAm).

[0:28:49] E nós iremos descartar... 3 nucleotídeos.

[0:28:52] Isso você pode fazer no final.

[0:29:01] Ta vai... "A", "U”, "G"...

[0:29:37] Ninguém terminou, só eu.

[0:29:39] Isso é sorte de principiante... risos.

[0:29:41] Ô loco!

[0:29:44] Vamos ver, por sorte eu também tenho a "RNA polimerase... risos. (nesse momento todos riram também)

[0:29:51] Alguém tem que puxar aquela cartinha lá de destruir o DNA... aliás RNAse.

[0:29:56] Mas ela já terminou!

[0:29:58] Mas ela ainda não saiu. (lembrando da regra para o uso da carta RNAse, que só pode ser apresentada a um jogador enquanto este estiver no núcleo)

[0:29:59] Tenho a "RNA polimerase", tenho aqui 5 nucleotídeos... só tem 5 nucleotídeos... legal!

[0:30:07] Destrói a proteína dela!... quer dizer, o RNA.

[0:30:10] Mas... eu não tenho esse poder ainda!... risos.

[0:30:12] Ai, que clima gente!

[0:30:13] Ahhhh... A gente tem! (nesse momento o BRENO estendeu suas mãos sobre o monte de compras como quem estivesse transmitindo alguma energia ou poder 
sobrenatural ou coisa do gênero... risos. Em seguida a KÁTIA também fez o mesmo gesto)

PAULO [0:30:19] Ah! Ela vai puxar um "sair da carioteca" (referindo-se retirada da carta "Atravessar a carioteca" do monte de compras pela KÁTIA).

JULIO [0:30:33] Qual eu vou descartar...

KÁTIA [0:30:43] Dá a saída para mim... risos.

$2^{\mathrm{a}}$ rodada

KÁTIA [0:31:05] Sou eu? Quantas cartas?

JULIO $\quad[0: 31: 06] 3$

Nesse momento o BRENO e o PAULO fizaram novamente o gesto de transmissão de energia, torcendo para ela não pegar a carta "Atravessar a carioteca".

JULIO [0:31:09] Então agora, como ela já completou, precisa o que?

PAULO [0:31:13] Só sair.

JULIO [0:31:15] Só atravessar a carioteca

PAULO $\quad[0: 31: 15]$ Atravessar a carioteca

JULIO [0:31:17] A carioteca é essa membrana aqui, então seria atravessar a carioteca. (mostrando no tabuleiro o que estava explicando)

Se você não tiver... (referindo-me a carta "atravessar a carioteca", voltando-me a KÁTIA).

Nesse momento a aluna KÁTIA balança a cabeça em sinal de negação

JULIO [0:31:24] Não tem? Então necessariamente você vai ter que descarta uma.

JUNIOR [0:31:34] Você poderia descartar uma com 10 nucleotídeos!!

KÁTIA [0:31:45] Éééé... RNA (referindo-se a carta que havia escolhido para descartar, uma "RNA polimerase". Carta essa que ninguém mais precisava. Portanto pensou antes de descartar). 
Nesse momento a dupla JUNIOR e BRENO pegou três cartas do monte de compra para iniciar sua jogada.

JULIO

[0:31:54] Vocês ainda estão aqui e precisam de nucleotídeos ainda, ta... (referindo-se ao fato de a dupla ainda estar construindo a molécula de RNA polimerase no núcleo).

Eles estão maquinando!!! (voltando-me para a KÁTIA e comentando o fato da dupla começar a rir ao adquirir as cartas e se inclinar sobre o tabuleiro e conversarem entre si como se estivessem definindo uma estratégia de jogo).

KÁTIA [0:32:01] Ai meu Deus!!! (com medo de eles terem adquirido a carta "RNAse" e estarem confabulando para "destruir" parte de seu RNA mensageiro).

Que medo!!

JUNIOR [0:32:08] Sete... esse aqui também conta? (referindo-se a contagem do número de nucleotídeos que faltava para eles terminarem a fase de transcrição).

JULIO [0:32:10] Qual esse aqui? (referindo-me a um símbolo que tem na fita do RNA mensageiro [...], indicando aos alunos que o RNA é muito maior do que simplesmente o que está mostrando)

KÁTIA [0:32:11] Conta.

JULIO [0:32:12] Onde tem esse quadradinho, você vai colocar assim (ou seja era para ele repetir o símbolo).

JUNIOR [0:32:16] Você conta como um nucleotídeo?

JULIO $\quad$ [0:32:17] Não.

BRENO

[0:32:18] Aêêêê!!! (em sinal de vibração).

JUNIOR [0:32:19] Então se aqui tem 7 contando com esse, é 6?

JULIO [0:32:23] Você precisa de quanto? Você precisa de 1, 2, 3, 4, 5, você precisa de 5 .

KÁTIA [0:32:28] 5? ... tem 6!

JULIO [0:32:35] Mas um aqui é o traçinho!!!... ta certo é 6, desculpe.

JUNIOR [0:32:36] A lá BRENO!

BRENO [0:32:37] É, a gente vai ter que descartar do mesmo jeito. (estava indignado, pois como pela regra ele tem que descartar uma carta $e$ as três cartas que estavam na mão eram com 
JUNIOR [0:32:40] Ó BRENO, tem aqui e tem aqui...

JULIO [0:32:42] Vocês tem que lembrar que tem que descartar uma. Lembra que eu falei que você poderia usar várias cartas...você pode ter até cinco, utilizar algumas e descartar uma.

BRENO [0:32:56] ... Não, mas a gente vai ter que descartar uma. (trecho que consegui transcrever, que corresponde ao final da conversa entre a dupla BRENO e JUNIOR, discutindo quais cartas utilizar e qual descartar, pois anteriormente estavam conversando juntamente comigo e não consegui distinguir)

PAULO [0:32:58] Sempre tem que descartar? Ou seja você pode utilizar as cartas que conseguir desde que você sempre descarte uma?... certo. (após a minha confirmação com a cabeça)

JULIO [0:33:05] É que a gente criou uma dinâmica assim... você está "segurando" as cartas, porque elas servem para o outro, mas tem situação que não tem jeito, você tem que descartar, aí você favorece o outro também.

JUNIOR [0:33:22] Então a gente vai usar essas duas e essa aqui vai embora... (referindo-se a estratégia utilizada para a jogada).

JULIO [0:33:28] Vocês tem que mostrar pra gente... Vai que vocês não estão falando a verdade!... risos. (por que o BRENO estava colocando as cartas que iria utilizar na jogada no monte de compras).

JUNIOR [0:33:32] ... três nucleotídeos, com mais esses três aqui... seis. Descartou uma...

JULIO [0:33:38] Então completa lá.... Qual que eles descartaram? Deixa eu ver se eu preciso... risos. (me aproximando para ver qual carta a dupla JUNIOR e BRENO havia descartado).

KÁTIA [0:33:46] Essa aqui? Três nucleotídeos ou ribossomo? (lendo a carta que a dupla anterior acabara de descartar).

GUTO [0:33:54] Pode escolher qual que você vai comprar do descarte? 
JULIO

[0:33:56] Lá não... deve seguir a ordem, não pode escolher qual você vai comprar.

Um silêncio enquanto a dupla JUNIOR e BRENO terminavam de preencher a seqüência correspondente de seu RNA mensageiro.

JULIO [0:34:26] Vocês praticamente já saíram

JUNIOR [0:34:28] Agora ele vem e destrói tudo aqui... risos. (referindo-se ao PAULO e ao GUTO, as próximas duplas a jogarem).

PAULO [0:34:39] Vamos ver... essa aqui...

JULIO

[0:34:43] Está pensando qual carta vai descartar?... e essa aqui? (apontando para uma carta que estava virada para baixo na mesa, não na mão do PAULO).

PAULO [0:34:47] Segredo!!

JUNIOR $\quad$ [0:34:50] Ah! Ele vai usar aquela carta... de destruir

KÁTIA [0:34:54] Ah! Não!

JUNIOR [0:34:57] A gente tem menos chance.

KÁTIA [0:34:59] Não... eu estou sozinha, não vale.

BRENO [0:35:02] Mas você tem duas cartas já, na sua mão.

JULIO [0:35:08] Tenho duas também.

JUNIOR [0:35:10] Nossa, é mesmo!

BRENO [0:35:14] A gente não tem nenhuma carta aqui para destruir você não, porque você vai querer destruir a gente.

PAULO [0:35:24] Pronto, a gente vai escolher. Aqui ó (mostrando uma carta com 8 nucleotídeos), aí a gente descarta isso aqui ó... RNA polimerase e ribossomo.

JUNIOR [0:35:35] Olha, eles sabem jogar! (voltando-se para o BRENO, seu parceiro).

KÁTIA [0:35:37] Risos, com certeza! (concordando com a afirmação do JUNIOR).

JUNIOR [0:35:40] A gente não escolhe cartas, a gente gasta todas. 
PAULO, para fazer um pouco de mistério e causar certo pânico nos adversários, começa a movimentar as duas cartas restantes, como se as mesmas fossem uma RNAse, por exemplo).

JUNIOR [0:35:55] A gente tem que sair com uma carta dessa! (referindo-se a carta "RNAse").

KÁTIA [0:35:56] Eu também!!

JULIO [0:36:01] Tenho duas, então posso comprar três... então, três nucleotídeos.

TODOS [0:36:22] Nossa!

JULIO [ [0:36:24] Tenho tanta carta, mas não saiu nada...

KÁTIA [0:36:29] Descarta "atravessar a carioteca" pra mim... risos.

3몸 roda

PAULO [0:36:58] Não vai sair nada... risos (torcendo para a KÁTIA não comprar a carta de que precisa, "atravessar a carioteca").

BRENO [0:37:00] O que precisa para sair da mesmo?

JULIO [0:37:02] Pra você sair daqui precisa de uma carta chamada "atravessar a carioteca"

KÁTIA [0:36:05] Humm!... b.... (após lembrar-se que estava sendo filma, levou a mão à boca e depois pediu desculpa. Essa atitude foi a decepção por não ter pego a carta que precisava).

Vou descartar essa.

JUNIOR [0:37:33] Não vai fazer mais nada?

KÁTIA [0:37:35] Não!... risos.

JULIO [ [0:37:37] Quem tiver a "RNAse" aí ó... risos.

JUNIOR [0:37:44] Aaaaaaaaaah! Nós conseguimos! (estavam eufóricos pois haviam conseguido comprar a carta "atravessar a carioteca”, podendo mudar para a etapa 2).

JULIO [0:37:55] Cadê a cadeia de vocês... então ao atravessar, vocês virão pra cá.

JUNIOR [0:38:00] Hum! E a gente não precisa descartar?

PAULO [0:38:02] Vão ter que descartar uma. 
BRENO [0:38:04] Agora, a gente já pode vir pra cá? (apontando para a região do tabuleiro correspondente a etapa 3).

JULIO

[0:38:05] Pra essa etapa 3, você precisa de ribossomo, você tem ribossomo?

BRENO [0:38:09] Temos

JULIO [0:38:10] Então vocês já podem vir pra cá. (colocando-os na região correspondente a etapa 3).

JUNIOR

[0:38:16] Fica, pra gente poder guardar... a gente tem duas... (ele não queria descartar uma carta que serviria para o grupo do PAULO).

BRENO [0:38:19] Não dá nada! Nós já saímos mesmo.

JULIO [0:38:20] Vocês tem que descartar uma.

KÁTIA [0:38:21] E descarta o... de tirar... (referindo-se a carta "atravessar a carioteca").

JUNIOR [0:38:27] BRENO! Eu não vou dar esse assim barato pra alguém...

JULIO [0:38:45] Não pode ser egoísta.

PAULO [0:38:56] É nóis!! (alegre por que a dupla JUNIOR e BRENO acabara de descartar uma carta que servia para eles).

BRENO [0:39:03] Mas vocês vão ter que comprar tudo daqui. (voltando-se para o PAULO, que estava prestes a comprar a carta que o BRENO havia descartado, e avisando que ele deveria escolher de que monte deveria comprar).

PAULO [0:39:04] Bem, isso não é um problema... pra quem tem duas vezes "atravessar a carioteca"... risos. Porque você acha que a gente ta guardando essas duas cartas? Somos c... (no sentido de Somos sacanas).

Pode colocar 5 (nucleotídeos).

JULIO [0:39:23] To ficando por último... (referindo-me a KÁTIA e eu). Essa proteína está meio atrasada hein!? (voltando-me para a KÁTIA, que esperava pela carta "atravessar a carioteca" enquanto as outras duplas passaram na frente).

PAULO [0:39:38] Vamos lá... a última foi "C" né;? Então agora é "G", "A", -, "U”, "A", "G", terminamos. Agora é o seguinte...

JULIO [0:40:07] Tem o "atravessar" aí? 
PAULO [0:40:13] Temos que usar o certo ó... esse aqui... ó, a gente usa esse "atravessar a carioteca"... aí a gente usa esse para esse aqui...

JUNIOR [0:40:35] Não podem destruir nada!!

Enquanto o PAULO e o GUTO discutem para decidirem que cartas usar e qual descartar, as outras duplas ficam impacientes e começam a pedir para que eles joguem logo.

JULIO [0:40:51] Eles estão maquinando... risos.

PAULO [0:40:54] Quando usaremos essa carta "RNAs Transportadores + aminoácidos?

JULIO [0:41:00] Vocês vão precisar aqui ó (apontando para a região correspondente a etapa 3), quando já tiverem o ribossomo. Porque qual é essa etapa aqui... o RNA transportador traz o aminoácido...

PAULO [0:41:08] Então tem que conseguir todos os aminoácidos... todos os... três aminoácidos significa que são três aqui? (apontando para o espaço destinado a escrever os aminoácidos correspondentes, na tradução).

JULIO $\quad[0: 41: 15]$ É, isso... ta certo.

PAULO [0:41:18] Ué, então a gente usou... isso.

JULIO [0:41:22] Não esqueçam que primeiro atravessam a carioteca... aí depois que vocês adquirem o ribossomo, vocês vem para cá, aí vocês começam a colocar os aminoácidos.

PAULO [0:41:30] Então tipo, tem essa carta aqui "RNAs transportadores + 3 aminoácidos"...

JULIO [0:41:34] Depois que vocês já tiverem o ribossomo.

PAULO [0:41:36] Sim... isso não é problema, a gente consegue... a gente consegue. Mas esses três aminoácidos significa que a gente risca 1 ou três aqui? (em dúvida quanto ao número de aminoácidos que contava, se era 1 na fita de aminoácido ou 3 no RNA mensageiro. Mostra que não ficou claro para ele o fato de que 3 nucleotídeos codificam para 1 aminoácido).

JULIO [0:41:43] Três aqui (apontando para ele a fita de aminoácidos). Aqui tem cinco, então você risca três. 
PAULO [0:41:50] Cada vez que vai um desses, significa que vai um daqueles naquela tabelinha?

JULIO

[0:41:52] É porque assim ó, cada três aqui (RNAm) é uma trinca e cada trinca codifica um aminoácido. Quer dizer que nessa fita $(R N A m)$ vai de 3 em 3 . Eu estou sem o código aqui, mas iríamos ver que por exemplo "AUG" codifica para um aminoácido aqui. No caso não são 3 ? Vocês estariam aqui. (mostrando que a cada 3 nucleotídeos que percorremos no RNA mensageiro, inserimos 1 aminoácido).

PAULO [0:42:17] Ta certo. A gente vai ter que descartar essa daqui... então é melhor usar essas aqui e descartar essa...

Então é o seguinte: a gente usa esse aqui pra atravessar, a gente usa esse, "Ribossomo", que também seria para atravessar a carioteca...hehe, e esse aqui para já transferir 4 aminoácidos. Vou ter que descartar essa aqui, infelizmente.

JULIO

[0:43:49] Então, olha só, quando o Ribossomo vai "ler" o RNA mensageiro ele vai de 3 em 3, ou seja cada trinca codifica um aminoácido, então aqui 1, 2, 3 e 4. (mostrando ao GUTO, que iria colocar a seqüência de aminoácidos na fita, como esse processo ocorreria na célula. Como se o Ribossomo deslizasse sobre o RNA mensageiro).

Então sou eu... tenho duas cartas, vou comprar três.

PAULO [0:44:11] Ah! A gente vai ganhar... risos.

JULIO [0:44:18] Bom, eu preciso de nucleotídeos, então tenho... 5 nucleotídeos... só 5 nucleotídeos.

PAULO [0:44:28] Esse jogo é meio rápido.

KÁTIA [0:45:30] Bom, eu vou pegar "atravessar a carioteca"

TODOS [0:45:34] Aaaaaâô̂ô... risos (devido ao fato de ter demorado até que ela conseguisse essa carta).

JULIO [0:45:36] Ninguém tirou "RNAse" ta vendo... só sobrou eu. Risos.

KÁTIA [0:45:37] Depois eu preciso de quê?

JULIO [0:45:40] Você precisa de ribossomo.

JUNIOR [0:45:43] Não joga ribossomo aí!!

PAULO [0:45:45] Coloca o que você usou na mesa... calma aí, só pode ter 5 cartas na mão. 


\begin{abstract}
KÁTIA [0:45:51] Nossa, é verdade!!
PAULO [0:46:01] Nossa, ainda bem que eu percebi.

JUNIOR [0:46:17] E aí? (perguntando para a KÁTIA se ela já havia terminado, para eles começarem sua jogada).

Nós pegamos essas três, que estavam ali em cima (monte de descarte). Eu vou usar essas duas... vou colocar 5 aminoácidos e a gente vai descartar essa.
\end{abstract}

BRENO [0:47:00] O que que eu faço? (não sabia como colocar os aminoácidos na fita destinada a isso). Eu já completei a fita né... legal... é só por "a"?

JULIO [0:47:05] É só por "a".

JUNIOR [0:47:06] Então a gente já saiu dali? (referindo-se a etapa 3)

JULIO [0:47:07] Calma... vocês não saíram daí ainda. No caso aí, a sua proteína ainda está na forma, como eu falei, é como se fosse uma "linha" formada por uma seqüência de aminoácidos. Pra ela ser funcional, primeiro ela precisa ser processada.

JUNIOR [0:47:22] Entendi, eu preciso ter a carta "processar proteína"

JULIO [0:47:24] Ou seja, ela vai ter a forma que ela precisa.

PAULO [0:48:25] Vou fazer um descarte, certo?

JULIO [0:48:30] Vai usar alguma aí?

PAULO [0:48:31] Não

BRENO [0:48:33] A gente só precisa pegar esse "destinar proteína"?

KÁTIA [0:48:35] Não, "processar proteína"!

JULIO [ [0:48:37] Processar primeiro...

BRENO [0:48:38] E depois é destinar?

JULIO [0:48:40] É.

Então eu preciso ainda de nucleotídeos, vamos ver... está quase acabando... 3... é sempre uma carta que tem alguma coisa.

PAULO [0:48:56] Então você deve ter um monte de carta boa aí... risos

JULIO [0:48:58] Calma que nós já vamos falar nisso aí... risos. 
PAULO [0:49:04] Ele deve estar com duas cartas "sacana" na mão.

JULIO

[0:49:24] Mas, calma aí que eu tenho alguma coisa aqui. Bom, como eu falei, tem uma cartinha aqui... eu falei que tinha duas cartas dessas "sacanagem", uma é a "RNAse" e a outra é a chamada "protease". Então por exemplo aqui você já está formando sua proteína e a protease serve pra que, pra cortar a proteína... risos.

BRENO [0:49:58] Que sacana!! (sabendo que seria o grupo dele seria "atacado").

JULIO [0:50:01] Eu tenho aqui a "protease"!

JUNIOR [0:50:02] Não!, não!, não! Você falou que não poderia usar depois...

JULIO [0:50:06] Eu falei que tinha duas, não falei?

PAULO [0:50:07] Falou

JULIO [0:50:07] Uma é a RNAse, só pode ser usada...

PAULO [0:50:10] Só remove dois!!

JULIO

[0:50:14] A gente fala metade, mas não dá para cortar um aminoácido no meio... pode ser dois aminoácidos só...

PAULO [0:50:20] Não tem carta com 2 aminoácidos, né?

KÁTIA [0:50:27] Tem mais dessas cartas?

JULIO [0:50:30] Não, dessa aí tem pouca senão o jogo não "anda", pois é todo mundo com essas cartas... risos (todos riram também).

KÁTIA [0:51:25] Droga!! (por não ter tirado a carta que precisava)

JULIO [0:51:26] Você precisava de ribossomo, não é? Então descarta uma

BRENO [0:51:48] Não falei! Dois aminoácidos...

JULIO [0:51:58] Pó, o cara tem o que ele precisa...

BRENO [0:52:00] Eu tenho o que eu quero, eu consigo assim o que eu quero, na hora que eu quero, quando eu quero, do jeito que eu quero...

PAULO [0:52:10] Tem que fazer com que demore mais... 
JULIO [0:52:11] Não, mas aqui não tem jeito, porque a fita é muito pequena.

PAULO [0:52:14] Não, mas faz cartinha com 1, 2, no máximo. (referindo-se as cartas com aminoácidos, que deveriam permitir colocar no máximo dois aminoácidos, não 3 ou 4, como algumas cartas).

[0:54:13] Ganhamos! Temos três, mas só precisamos colocar 2 (aminoácidos). Agora vamos processar a proteína e destiná-la. Risos.

JULIO [0:54:30] Olha só, só para a gente fechar aqui... já que é um jogo didático... Se destinou a proteína, ela tem que ir pra onde?

KÁTIA [0:54:41] Cito...sol

JULIO [0:55:00] (nesse momento lemos juntos o objetivo de sua proteína (adrenalina)

Aí assim, vocês conseguiram entender tudo?

PAULO [0:55:43] Sim, sim, sim... adrenalina nos deixa alerta... risos.

JULIO [ [0:55:48] Muito obrigado pela participação de vocês. 